\title{
CICLAGEM DE NUTRIENTES APÓS APLICAÇÃO DE LODO DE ESGOTO (BIOSSÓLIDO) SOBRE LATOSSOLO CULTIVADO COM Eucalyptus Grandis
}

\section{MARCELINO CARNEIRO GUEDES}

Tese apresentada à Escola Superior de Agricultura "Luiz de Queiroz", Universidade de São Paulo, para obtenção do título de Doutor em Recursos Florestais, Opção: Silvicultura e Manejo Florestal.

P I R A C I C A B A

Estado de São Paulo - Brasil

Fevereiro- 2005 


\section{CICLAGEM DE NUTRIENTES APÓS APLICAÇÃO DE LODO DE ESGOTO (BIOSSÓLIDO) SOBRE LATOSSOLO CULTIVADO COM Eucalyptus Grandis}

\section{MARCELINO CARNEIRO GUEDES \\ Engenheiro Florestal}

Orientador: Prof. Dr. FÁBIO POGGIANI

Tese apresentada à Escola Superior de Agricultura "Luiz de Queiroz", Universidade de São Paulo, para a obtenção do título de Doutor em Recursos Florestais, Opção: Silvicultura e Manejo Florestal.

PIR A C I C A B A

Estado de São Paulo - Brasil

Fevereiro- 2005 
Dados I nt er naci onai s de Cat al ogação na Publ i cação ( CI P) DI VI SÃO DE BI BLI OTECA E DOCUMENTAÇÃO - ESALQI USP

\section{Guedes, Marcelino Carneiro}

Ciclagem de nutrientes após aplicação de lodo de esgoto (biossólido) sobre latossolo cultivado com Eucalyptus grandis / Marcelino Carneiro Guedes. - -

Piracicaba, 2005.

$154 \mathrm{p}$.

Tese (Doutorado) - - Escola Superior de Agricultura Luiz de Queiroz, 2005. Bibliografia.

1. Biogeoquímica 2. Ciclagem de nutrientes 3. Crescimento vegetal 4. Eucalipto 5. Latossolo 6. Lodo de esgoto 7. Nutrição vegetal I. Título

CDD 634.9734 


\section{BIOGRAFIA DO AUTOR}

Marcelino Carneiro Guedes, filho de Ethevaldo Magalhães Guedes e Thereza Catharina Carneiro Guedes, nasceu no dia 02 de junho de 1972 em um pequeno vilarejo de Minas Gerais chamado Barretos de Alvinópolis. Brincando nas ruas de terra, nas matas e montanhas, aprendeu a valorizar a liberdade e a gostar da convivência com a natureza. A necessidade de encarar o mundo já aparece aos dez anos, quando muda-se para a casa da tia Lucinda, em Rio Piracicaba, para cursar o ginasial e o segundo grau na Escola Estadual Prof. Antônio Fernandes Pinto. A angústia e a timidez, constantes nos primeiros meses e anos, foram aos poucos superadas com constantes viagens de volta à quietude de Barretos. Os latões do caminhão de leite, os atoleiros, chuva, frio, poeira, sol, nada impedia a volta ao aconchego. Naquela época, ainda não tinha maturidade para responder aos que riram, grosseira e estupidamente, das viagens no caminhão e para não sentir vergonha de ser da roça. Em 1990 concluiu os cursos de Magistério e Técnico de Mineração, mesmo internado em um hospital para retirada de um rim. A recuperação em 1991 impossibilitou os sonhos da faculdade. Com o falecimento da mãe em 04 de janeiro de 1992, tudo desabou e novamente os sonhos iam por terra. Uma força, que só pode ter vindo dela, levou-o a fazer aquele vestibular, mesmo sem ter feito cursinho e sem ter estudado, e surgiu em forma de inspiração durante a redação "Eu e o outro: oposição e complementação". Um tema desconcertante se transformou em uma redação de poucas palavras, sem rascunhos nem vacilação, e na quase totalidade dos pontos, possibilitando a entrada na segunda chamada. 
Depois de cinco anos de muito estudo e esforço, mas também de muitas greves, festas, convivências maravilhosas e novos horizontes, formou-se em Engenharia Florestal no dia 28 de fevereiro de 1997, na Universidade Federal de Viçosa. Mais um ano de aperfeiçoamento no Departamento de Solos, em Viçosa, MG, foi o tempo necessário para confirmar a decisão de fazer pósgraduação na ESALQ. A distância da família, da quietude e do aconchego já não assustava mais. A necessidade de ir era mais forte, assim como o orgulho de ser caipira sim e a certeza de que a família e as origens devem sempre balizar os rumos de qualquer trajetória. Em 1998 ingressa no curso de mestrado do Programa de Pós-graduação em Ciências Florestais, estruturado junto ao Departamento de Ciências Florestais, da ESALQ/USP, em Piracicaba, SP. Conclui o curso em janeiro de 2001 e logo ingressa no curso de doutorado, em março de 2001. Em janeiro de 2005 termina o doutorado em Recursos Florestais, na opção Silvicultura e Manejo Florestal. Durante os seis anos em Piracicaba, uma nova fase. Vieram a mulher e os filhos, muitos amigos, o despertar para a necessidade de praticar a consciência política e exercitar a cidadania. Algumas vezes a frustração também esteve presente. A falta de ética, o estrelismo e o desrespeito por parte de algumas pessoas, que estão ajudando a formar profissionais e cidadãos, causaram enorme desalento. Mas a vontade de contribuir para a melhoria deste país, impulsiona para novos e distantes rumos. O desenvolvimento sustentável da Amazônia é o mais recente desafio. Sabe-se que esse desafio não é tarefa para poucos. Contudo, grandes conquistas se constróem com a vontade sincera e com pequenas contribuições de cada um que acredita que a sua parte pode fazer diferença. 


\section{DEDICATÓRIA}

Ofereço mais esta conquista à minha família, sempre referência e base para minhas atividades e atitudes. Ao meu pai Ethevaldo, exemplo de resignação e de que os atos valem muito mais do que as palavras. À memória de minha mãe Thereza, que soube conquistar respeito e admiração de todas as pessoas que a conheceram. Aos meus irmãos e irmãs (Maria Inêz, Afonso, Sérgio e Elisa); que possamos permanecer sempre unidos. Aos novos companheiros de cotidiano (minha esposa Ana Cláudia, meus filhos Pedro Miguel, Alex, Túlio e ao que está a caminho); fonte de ânimo e reconforto nesta longa jornada. Que saibamos cultivar a boa convivência, a simplicidade dos pequenos atos e ser suporte mútuo para nosso desenvolvimento e aprimoramento.

Às pessoas humanas, ainda humanizadas. Que a coisificação da vida, a banalização da violência, a injustiça e a lei do mais forte não imperem sobre o SER HUMANO e a solidariedade; que as pessoas se associem a causas maiores que não caibam nos próprios umbigos; que não ajam simplesmente por interesses próprios e com o objetivo de tirar proveito de todas as situações. 


\section{AGRADECIMENTOS}

À Fundação de Amparo à Pesquisa do Estado de São Paulo (FAPESP), pelo ano de bolsa de doutorado e pelo auxílio à pesquisa;

à Coordenação de Aperfeiçoamento de Pessoal do Ensino Superior (CAPES), pelos três meses de bolsa no início do curso e por disponibilizar esta importante ferramenta de revisão bibliográfica que é o Portal de Periódicos;

à Companhia de Saneamento Básico do Estado de São Paulo (SABESP), pelo financiamento de parte desta tese e do projeto de pesquisa coordenado pelo prof. Fábio Poggiani: "Estudo de Parâmetros de Aplicação do lodo da Estação de Tratamento de Esgoto (ETE) de Barueri no plantio de Eucaliptos" através do contrato 052/97-B firmado com o Instituto de Pesquisa e Estudos Florestais (IPEF);

à Empresa Brasileira de Pesquisa Agropecuária (EMBRAPA), por acreditar na qualificação de seus funcionários e pela liberação para conclusão do curso de doutorado;

À Embrapa Instrumentação Agropecuária, pelas análises de ressonância magnética nuclear 
aos funcionários da Estação Experimental de Itatinga, pelo constante apoio durante o desenvolvimento do trabalho.

ao pesquisador Jean-Paul Laclau, pelas sugestões durante o exame de qualificação e pelo empréstimo dos lisímetros e da bomba de sucção. Apesar das dificuldades, a experiência valeu muito;

aos meus pares e à Comissão de Pós-Graduação da ESALQ, pela oportunidade de ser representante discente, exercer cidadania e desenvolver a consciência política;

aos amigos e colegas, pelos excelentes momentos de descontração;

a todas as pessoas que colaboraram com o desenvolvimento do trabalho, especialmente:

ao professor Fábio Poggiani, pela confiança e pela orientação;

aos professores José Luiz Stape e Arnaldo Rodella, pelas críticas e sugestões apresentadas durante a qualificação;

a todos os professores e estudantes que participaram do projeto SABESP Itatinga, pela profícua convivência e interação;

à colega Marta Velasco-Molina, pelo empréstimo das amostras de solo. 


\section{SUMÁRIO}

RESUMO

2.1.1 Contexto histórico ...................................................................... 9

2.1.2 Biossólido ou lodo de esgoto? ....................................................10

2.1.3 Possíveis problemas................................................................... 14

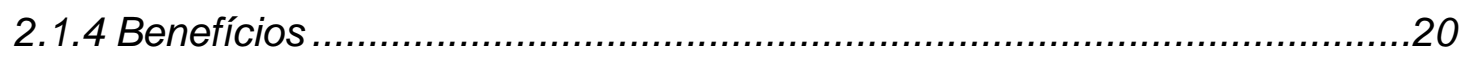

2.1 .5 Utilização em florestas..........................................................22

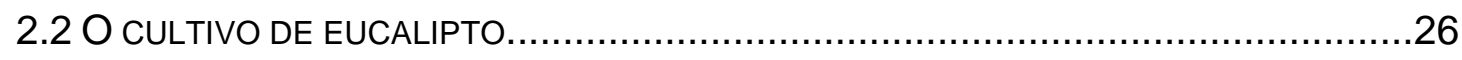

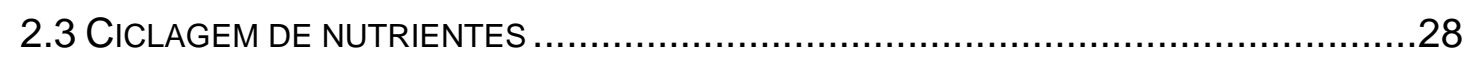

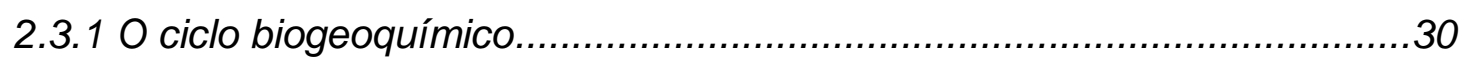

2.3.2 O processo de decomposição e a liberação de nutrientes .......................32

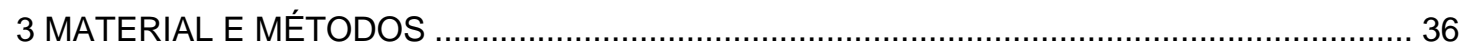

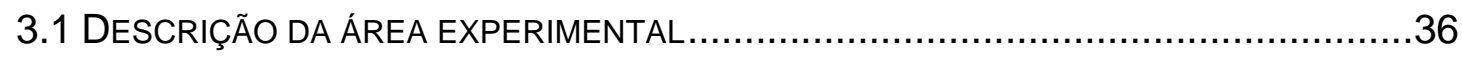

3.1.1 Situação geográfica ............................................................... 36

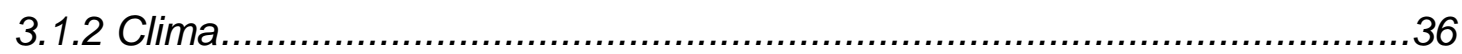

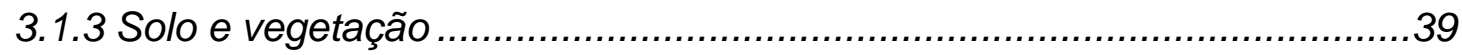

3.1.4 Plantio e tratos silviculturais...................................................40 
3.2 CARACTERIZAÇÃO E APLICAÇÃO DO BIOSSÓLIDO..........................................40

3.3 DELINEAMENTO EXPERIMENTAL E TRATAMENTOS .....................................42

3.4 COLETA E COMPOSIÇÃO DAS AMOSTRAS ....................................................44

3.4.1 Serapilheira depositada e acumulada............................................44

3.4.2 Decomposição do folhedo .............................................................46

3.4.3 Solo e biossólido remanescente ....................................................47

3.4.5 Componentes das árvores abatidas (lenho, casca, folha e galho) ...........47

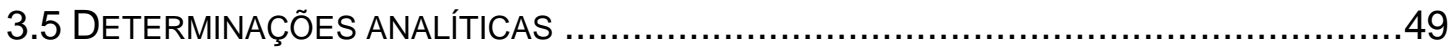

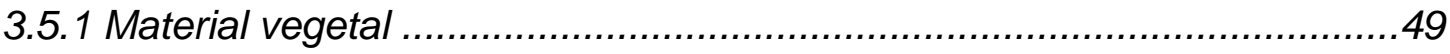

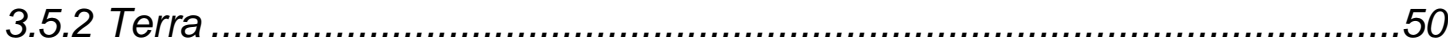

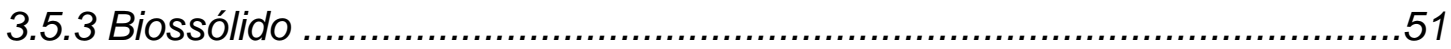

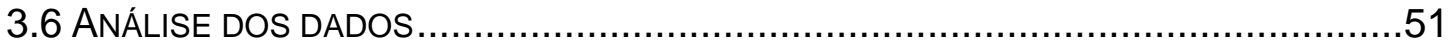

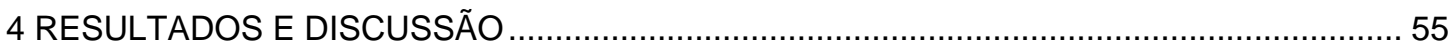

4.1 DEPOSIÇÃO DE SERAPILHEIRA E RETORNO DE NUTRIENTES AO SOLO ...................55

4.2 DEGRADAÇÃO DO BIOSSÓLIDO E DO FOLHEDO DE EUCALIPTO ...........................96

4.3 ESTOQUE DE NUTRIENTES NOS COMPARTIMENTOS DO ECOSSISTEMA ................113

4.3.1 Fitomassa epígea dos eucaliptos.............................................113

4.3.2 Serapilheira e biossólido remanescente sobre o solo...........................129

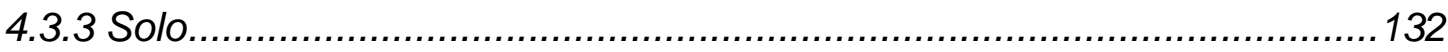

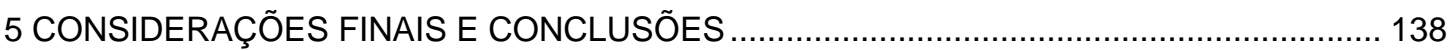

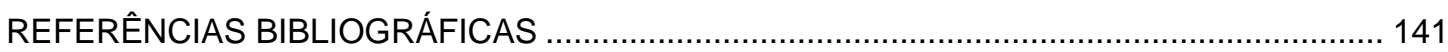




\title{
CICLAGEM DE NUTRIENTES APÓS APLICAÇÃO DE LODO DE ESGOTO (BIOSSÓLIDO) SOBRE LATOSSOLO CULTIVADO COM Eucalyptus Grandis
}

\author{
Autor: MARCELINO CARNEIRO GUEDES \\ Orientador: Prof. Dr. FÁBIO POGGIANI
}

\section{RESUMO}

O tratamento das águas residuárias gera um resíduo, o lodo de esgoto, que poderia ser utilizado para aumentar a produtividade de culturas agrícolas e florestais. O objetivo geral deste trabalho foi estudar como a utilização do biossólido em um povoamento de Eucalyptus grandis afeta a ciclagem biogeoquímica de nutrientes. O estudo foi desenvolvido na Estação Experimental de Itatinga, vinculada ao Departamento de Ciências Florestais da ESALQ/USP. O experimento foi instalado em março de 1998 em um delineamento em blocos casualizados, com cinco tratamentos (testemunha, adubação mineral, $10 \mathrm{Mg} \mathrm{ha}^{-1}$ de biossólido $+\mathrm{KP}, 20 \mathrm{Mg} \mathrm{ha}^{-1}$ de biossólido $+\mathrm{K}$ e $40 \mathrm{Mg} \mathrm{ha}^{-1}$ de biossólido $+\mathrm{K}$ ). Os resultados mostraram que a aplicação de biossólido alterou o desenvolvimento e o estado nutricional dos eucaliptos, bem como os padrões de reciclagem dos nutrientes. A produção de fitomassa arbórea pelos eucaliptos que receberam $10 \mathrm{Mg} \mathrm{ha}^{-1}$ de biossólido $+\mathrm{K}$ e P mineral foi significativamente maior do que no tratamento testemunha e, em média, maior também do que na fertilização mineral. Com as doses de 
biossólido, também foi verificado um significativo aumento na produção de serapilheira e na devolução de nutrientes ao solo. Durante quatro anos de desenvolvimento, as árvores que receberam a maior dose de biossólido produziram e devolveram ao solo $20 \mathrm{Mg} \mathrm{ha}^{-1}$ de folhedo, $5340 \mathrm{~kg} \mathrm{ha}^{-1}$ de folhas senescentes a mais do que as árvores testemunhas e $2422 \mathrm{~kg} \mathrm{ha}^{-1}$ a mais do que os eucaliptos que receberam adubação. O biossólido alcalino utilizado apresentou reduzidas taxas de degradação. Apenas o biossólido que foi aplicado em uma dose de $20 \mathrm{Mg} \mathrm{ha}^{-1}$ diminuiu sua massa seca em mais de $50 \%$, chegando a taxa média igual a 2,42 $\mathrm{Mg} \mathrm{ha}^{-1} \mathrm{ano}^{-1}$. A aplicação de biossólido não alterou a taxa de perda de massa do folhedo de eucalipto. No entanto, o resíduo afetou a dinâmica de mineralização e liberação de nutrientes, principalmente, evitando a imobilização de $\mathrm{N}$ e acelerando sua liberação das folhas em decomposição. Os eucaliptos do tratamento "10+KP" apresentaram maior quantidade de fitomassa epígea acumulada em todos os componentes, o que resultou em $62 \%$ a mais de fitomassa total nessas árvores em relação às testemunhas. Para esses eucaliptos, que apresentaram maior produtividade, a fitomassa total de tronco acumulada em cinco anos foi de 94,9 $\mathrm{Mg} \mathrm{ha}^{-1}$; conseqüentemente, o incremento médio anual (IMA) foi de $19 \mathrm{Mg} \mathrm{ha}^{-1} \mathrm{ano}^{-1}$. Este tratamento "10+KP" apresentou também maior mineralomassa de $N, P, S$ e Zn. Por outro lado, apresentou menores valores de mineralomassa de Ca do que os os tratamentos " $20+K$ " e "40+K", assim como menor mineralomassa de $\mathrm{Mg}$ do que os eucaliptos que receberam adubação mineral. A aplicação de biossólido propiciou, na fase final da rotação, maiores estoques de nutrientes em todos os compartimentos do ecossistema. O capital lábil de P, Ca e Zn no solo onde foi aplicado biossólido foi maior do que no solo adubado, o que evidencia maior capacidade em manter a sustentabilidade produtiva do ecossistema quando se aplica biossólido. 


\title{
NUTRIENTS CYCLING AFTER SEWAGE SLUDGE (BIOSOLID) APLLICATION ON OXISOL PLANTED WITH Eucalyptus Grandis
}

\author{
Author: MARCELINO CARNEIRO GUEDES
}

Adviser: Prof. Dr. FÁBIO POGGIANI

\section{SUMMARY}

The treatment of wastewaters generates the sewage sludge, a residue that could be used to increase the productivity of both farming and forest plantations. The general aim of this work was to evaluate how biosolid affects the biogeochemistry of nutrients at an Eucalyptus grandis plantation. The study site is at the Experimental Station of Itatinga, linked to the Forest Sciences Department of the ESALQ/USP. The trial was installed on March 1998 in randomized blocks design, with five treatments (control, inorganic mineral fertilizer, $10 \mathrm{Mg} \mathrm{ha}^{-1}$ of biosolid + KP, $20 \mathrm{Mg} \mathrm{ha}^{-1}$ of biosolid $+\mathrm{K}$ and $40 \mathrm{Mg} \mathrm{ha}^{-1}$ of biosolid $+K)$. The results showed that the biosolid application alters both the development and the nutritional state of eucalypts, as well as the patterns of nutrients recycling. There was an significant increment in the arboreal biomass production of the eucalypts that received $10 \mathrm{Mg} \mathrm{ha}^{-1}$ of biosolid + mineral $\mathrm{K} \mathrm{e} \mathrm{P}$, in relation to the control treatment, and higher average production than the eucalypts that received full mineral fertilization. With the increase of biosolid rates, there was a significant increase on the production of litter-fall and on the nutrients soil devolution. During four years, the trees under the largest biosolid dose produced and returned to the soil $20 \mathrm{Mg}$ of leaves-fall, $5340 \mathrm{~kg}$ more than 
the control trees and $2422 \mathrm{~kg}$ more than the eucalypts that received fertilization. The used alkaline biosolid presents reduced degradation rates. Just the biosolid applied at a $20 \mathrm{Mg} \mathrm{ha}^{-1}$ dose reduced the dry mass by more that one half, reaching a medium rate of $2.42 \mathrm{Mg} \mathrm{ha}^{-1}$ year $^{-1}$. The biosolid application does not alter the leaves-fall eucalypts mass loss rate, appraised in senescent leaves. However, the residue affects the mineralization dynamics and nutrients liberation, mainly, by blocking the immobilization of $\mathrm{N}$ and accelerating its liberation from the leaves decomposing. The eucalypts under the treatment "10+KP" presented more accumulated biomass in all of their components, so they reached $62 \%$ more aboveground biomass in comparison to the control plants. For those eucalypts that presented the highest productivity, the total biomass of trunk accumulated in five years was $94,9 \mathrm{Mg} \mathrm{ha}^{-1}$; consequently, the mean annual increment (MAl) was of $19 \mathrm{Mg} \mathrm{ha}^{-1} \mathrm{year}^{-1}$. The treatment "10+KP" also presented high mineral mass of $\mathrm{N}, \mathrm{P}, \mathrm{S}$ and $\mathrm{Zn}$. By the other hand, the treatment "10+KP" presents smaller values of mineral mass of $\mathrm{Ca}$ than the eucalypts under the treatments " $20+K$ " and "40+K" and smaller mineral mass of $\mathrm{Mg}$ than the eucalypts that received mineral fertilization. In the final phase of the rotation, the biosolid increased the nutrients stocks in all compartments of the ecosystem. The $\mathrm{P}, \mathrm{Ca}$ and $\mathrm{Zn}$ labile pool soil was higher with biosolid application than fertilized soil, what assures higher capacity in maintaining sustainability productivity of the ecosystem when biosolid is applied. 


\section{INTRODUÇÃO}

É preciso encontrar alternativas urgentes para a situação caótica dos grandes centros urbanos, originada principalmente pela concentração demográfica desordenada e pela urbanização sem planejamento. Com o desenvolvimento descontrolado das áreas urbanas, o resultado foi a formação de cidades sem infra-estrutura e sem disponibilidade de serviços capazes de atender a população. Nos grandes centros urbanos cada vez se acentua mais a perda de qualidade de vida e o desequilíbrio ambiental, principalmente, nas áreas periféricas. Por exemplo, as dificuldades para se obter água potável e para dispor adequadamente os resíduos são crescentes e diretamente proporcionais ao número de habitantes. Em um mundo cada vez mais urbano e concentrado, o aumento demográfico e o desenvolvimento de tecnologias impactantes caminham lado a lado com o aumento da poluição, chegando a níveis acima da capacidade homeostática da Biosfera .

A escassez de água vem sendo sentida em várias regiões do planeta. Além da escassez, a poluição dos mananciais dificulta o tratamento e muitas vezes inviabiliza seu uso para abastecimento humano. Atualmente, o lançamento de esgoto direto nos cursos de água é uma das principais fontes de contaminação dos recursos hídricos. A necessidade do tratamento dos esgotos para evitar essa contaminação é clara e incontestável. No entanto, o tratamento 
também gera um resíduo (o lodo de esgoto), que, dependendo do manejo ao qual é submetido, pode criar outros problemas ecológicos e sanitários. Por outro lado, o problema do lodo de esgoto é, de certa forma, um sinal positivo; pois, sua existência indica que está sendo realizado o tratamento prévio do esgoto e que as questões sanitárias básicas já foram resolvidas.

Recentemente, na Conferência Rio + 10, em Johannesburgo na África do Sul, um dos poucos temas sobre o qual houve consenso entre todos os países e o estabelecimento de metas a serem cumpridas foi referente à questão do saneamento básico e tratamento dos esgotos. Com o aumento do tratamento, cada vez mais lodo será gerado e se criará mais demanda para a destinação adequada desse resíduo.

A Agenda 21 Brasileira (1995) - em sua área temática intitulada Agricultura Sustentável, onde a necessidade da recuperação de solos erodidos e empobrecidos é amplamente discutida - incentiva o uso do lodo de esgoto doméstico como adubo orgânico em práticas para conservação e recuperação dos solos, mediante a garantia de que não ocorram impactos ambientais negativos. Apesar disso, a maior parte do lodo gerado no Brasil ainda é destinada a aterros sanitários. Além de representar elevados custos financeiros, que podem atingir $40 \%$ do custo operacional de uma estação de tratamento de esgotos (Tsutya, 2000), a disposição em aterro pode gerar problemas sociais para a população residente em suas periferias. A disponibilidade de áreas adequadas próximas aos grandes centros urbanos também é uma séria restrição à construção de novos aterros, que deveriam receber apenas resíduos sem qualquer possibilidade de reciclagem. A própria prática de disposição de resíduos em aterros não é sustentável, considerando uma escala temporal de longo prazo. Como a população vai continuar gerando resíduos perpetuamente e as áreas apropriadas e disponíveis para a construção de aterros irão diminuir, essa disposição não pode ser sustentável e deve ser minimizada. A presença de resíduos orgânicos nos aterros causa uma série de preocupações aos 
operadores do sistema, gerando problemas como a produção de chorume e abatimento de partes do aterro devido à decomposição da carga orgânica, tornando a presença desses resíduos, particularmente, altamente indesejável. Vários países já contam inclusive com restrições legais à disposição de resíduos orgânicos em aterros sanitários.

O esgotamento das soluções paliativas e provisórias para a disposição final do lodo gerado nas estações tem levado a todos os técnicos envolvidos com esta questão, a preocupação de encontrar soluções mais efetivas de longo prazo. Segundo Matthews (1998), o futuro da disposição de lodo deverá ser, predominantemente, a incineração ou o uso como biossólido. O biossólido é o lodo de esgoto devidamente tratado para não apresentar riscos à saúde humana, animal e ao meio ambiente, com potencial de uso benéfico em sistemas agroflorestais.

Corrêa \& Corrêa (2001) valorizaram o biossólido como fonte de nitrogênio, fósforo e matéria orgânica, utilizando o método de "mercado de bens substitutos" para uma avaliação econômica desse resíduo. Segundo esses autores, o valor do lodo fresco atingiu $\mathrm{R} \$ 22,00$ a tonelada. Mas, apesar do valor do biossólido como fonte de nutrientes, não se pode esquecer que se trata de um resíduo do processo de tratamento do esgoto, cuja disposição final é de responsabilidade da unidade geradora. Assim, o valor nutricional do biossólido para cultivos agrícolas e florestais ainda não pode ser convertido em valor monetário, pois, tendo status de resíduo, esse material não pode ter preço e ser vendido. Para adquirir status de "produto ou matéria-prima", é preciso se ter a certeza de que o material não causará nenhum dano ao ambiente e à saúde humana e animal. Afirmar isso, atualmente no Brasil, seria prematuro, devido principalmente às escassas pesquisas em território nacional, à elevada variabilidade que existe na composição dos lodos gerados em diferentes estações e também devido à ausência de uma legislação federal específica que regulamente a utilização do biossólido. 
Uma das alternativas mais viáveis e promissoras de uso do biossólido é a reciclagem desse material em plantações florestais destinadas à produção de madeira. Se as pesquisas comprovarem a viabilidade sócio-ecológica, silvicultural e econômica da utilização de biossólido em culturas florestais, este resíduo, cujo destino é hoje problemático, no futuro poderá ser considerado um insumo, gerando assim um estímulo a mais para que os esgotos urbanos sejam tratados e não venham a eutrofizar e poluir os cursos de água. Melhorando a qualidade da água e aumentando o saneamento básico, haverá um efeito direto sobre a questão da saúde pública da população.

Esta pesquisa faz parte de um programa temático que envolve uma equipe multidisciplinar composta por vários docentes e pós-graduandos de três departamentos da ESALQ e do CENA, cujo objetivo principal é pesquisar a viabilidade da aplicação de biossólidos em florestas plantadas. É um programa pioneiro no Brasil e procura demonstrar que existe elevado potencial para associar o destacado desenvolvimento nacional na silvicultura, principalmente na cultura de eucalipto, ao manejo benéfico de biossólido, sem causar problemas ambientais relevantes. Os possíveis problemas associados à utilização de biossólido, como concentrações elevadas de metais pesados e nitratos, estão sendo monitorados e estudados, desde 1998, em subprojetos específicos do programa ao qual este trabalho está vinculado. Até o presente momento, os resultados são promissores. No entanto, não se pode perder de vista o caráter ainda experimental da aplicação de biossólido em florestas, no Brasil. Será preciso se ter a certeza de que essa atividade não trará nenhum prejuízo ao ambiente e às pessoas que lidam com esse resíduo e saber se a resposta em produtividade da cultura do eucalipto irá favorecer sua economicidade, antes de estimular o uso extensivo. Além disso, há a necessidade de gerar uma fonte de dados para se aprimorar a legislação nacional pertinente, que foi formulada a partir das normas americanas e deve 
ser adaptada para as diferentes localidades e características do território brasileiro.

No desenvolvimento deste trabalho foi estudado como a aplicação de biossólido afeta a ciclagem de nutrientes, considerando que o estudo dos nutrientes é uma ferramenta que permite ao pesquisador e ao manejador obter informações imprescindíveis, tanto para trabalhar a questão da produtividade, quanto para buscar a sustentabilidade ambiental. A manutenção ou o aumento da produtividade do ecossistema ao longo do tempo é fundamental para a sustentabilidade econômica. Para que isso ocorra com custos mínimos é necessário um bom manejo dos nutrientes e a manutenção da fertilidade (química, física e biológica) do solo; da qual depende, basicamente, a capacidade produtiva do local. Em plantações de eucalipto o bom manejo de nutrientes é dificultado, pois, normalmente, a cultura é desenvolvida sobre solos de baixa fertilidade natural e há uma elevada exportação de nutrientes do ecossistema quando se realiza a colheita florestal. Do ponto de vista da sustentabilidade ambiental, um aspecto fundamental da viabilidade ecológica é a capacidade do ecossistema de reciclar a energia e os nutrientes, diminuindo a necessidade de entradas externas, tornando-se mais conservativo e autosustentável.

Para realizar esse estudo foram abordados dois aspectos da ciclagem biogeoquímica de nutrientes, considerando que o ecossistema pode ser dividido em distintos compartimentos interligados pelas taxas de transferência de energia e nutrientes. Um é o aspecto dinâmico, cuja abordagem é realizada através da avaliação das taxas de deposição de serapilheira produzida pelas árvores ao longo de seu desenvolvimento e das taxas de decomposição do biossólido e do folhedo acumulado sobre o solo. O outro aspecto retrata o estado pontual dos compartimentos do ecossistema cinco anos após o plantio dos eucaliptos. Esse aspecto, que depende das condições iniciais e das taxas de transferência anteriormente citadas, foi avaliado através da determinação 
dos estoques de nutrientes nos componentes do ecossistema (solo, biossólido, serapilheira e fitomassa epígea dos eucaliptos).

A hipótese geral que norteou a elaboração da pesquisa foi que a aplicação de biossólido favorece a reciclagem de nutrientes durante a primeira rotação da cultura de eucalipto, com reflexos sobre os processos de produção e decomposição da serapilheira; assegurando ao final da rotação maior disponibilidade de nutrientes no solo e maior capacidade do ecossistema em manter a sustentabilidade produtiva do sítio do que a adubação mineral. A seguir são listadas as hipóteses específicas:

1) A aplicação de biossólido propicia maior produção de serapilheira (folhas, galhos e cascas) pelas árvores. Assim, deve haver maior transferência de nutrientes das árvores para a manta florestal em áreas que receberam o resíduo. A quantidade de matéria orgânica gerada através do aumento da produção de serapilheira pelas árvores tratadas com biossólido é maior do que a própria matéria orgânica adicionada inicialmente com a aplicação do biossólido.

2) A utilização de biossólido acelera a decomposição do folhedo de eucalipto, devido a promoção da melhoria da qualidade do material orgânico das folhas senescentes. O biossólido alcalino apresenta baixas taxas de degradação.

3) O solo das parcelas experimentais que receberam o resíduo deve apresentar maiores estoques de nutrientes ao final da rotação. A alocação de nutrientes para os componentes das árvores (lenho, casca, galhos e folhas) e a partição entre os compartimentos do ecossistema (solo, serapilheira e vegetação) deve ser alterada pela aplicação de biossólido.

De acordo com as hipóteses que nortearam o planejamento do estudo, foram elaborados os objetivos do projeto. O objetivo geral do trabalho foi verificar como o biossólido afeta a ciclagem biogeoquímica de nutrientes em um povoamento de E. grandis, até os cinco anos de idade, e compreender como o 
biossólido altera taxas de transferência e os estoques de nutrientes no ecossistema, verificando se a capacidade do resíduo é maior do que a capacidade da adubação mineral de manter a sustentabilidade produtiva do sítio. Foram objetivos específicos:

1) Quantificar a fitomassa produzida e o conteúdo de nutrientes devolvidos ao solo através da derrubada de folhas, de galhos e cascas; verificando o efeito indireto do biossólido, através da comparação entre a quantidade de matéria orgânica e nutrientes depositados via serapilheira e a quantidade colocada inicialmente através de doses crescentes do resíduo.

2) Avaliar como a taxa de perda de massa e a liberação de nutrientes do folhedo em decomposição são alteradas pela aplicação de biossólido e quantificar o biossólido remanescente cinco anos após a aplicação, estimando sua taxa de degradação.

3) Estimar a distribuição da fitomassa e o conteúdo dos nutrientes nos diferentes componentes das árvores com cinco anos de idade e contabilizar os estoques dos nutrientes nos diferentes compartimentos do ecossistema.

Para se atingir os objetivos propostos, a metodologia científica utilizada seguiu o paradigma dominante na ciência moderna, fundamentado na experimentação e na observação. Apesar de ainda preso pelo empirismo e pelo positivismo da racionalidade científica, buscou-se desenvolver essa tese sob uma tênue luz de uma nova concepção de ciência. Nessa nova concepção, não é mais possível a total separação entre a natureza e o ser humano, a dicotomia entre ciências naturais e sociais não faz sentido e a única certeza é que não há fundamento único, último e seguro do conhecimento. Os saberes locais, sistematicamente ignorados pela ciência moderna, que atribuiu à técnica e aos cientistas a missão providencial de solução de todos os problemas da humanidade, passam a ser valorizados na nova concepção de ciência e podem complementar a excessiva especialização e disciplinarização do saber científico. Segundo Targino et al. (2003), as normas sociais afetam as do 
mundo científico pois o indivíduo não pode ter duas escalas de valores morais uma para seu uso como cidadão e outra para o profissional.

O presente trabalho foi desenvolvido com a esperança de contribuir para um melhor entendimento e aprimoramento do uso de biossólido na cultura do eucalipto e para que esse conhecimento possa ser utilizado no desenvolvimento de sistemas de gerenciamento que se revertam em benefícios para a sociedade. Em suas bases filosóficas estão as idéias de que a comunidade científica não pode ficar isolada nas academias e nos centros de pesquisa, sem considerar o contexto social em que está envolvida; que os resultados da pesquisa não pertencem ao cientista, mas à sociedade e que a paixão pelo conhecimento e o interesse verdadeiro pelo destino da humanidade é que devem mover a pesquisa. 


\section{REVISÃO DE LITERATURA}

\subsection{Lodo de esgoto (biossólido)}

\subsubsection{Contexto histórico}

A utilização de dejetos humanos na agricultura remonta à China antiga, há milênios de anos, quando os orientais utilizavam os dejetos, "in natura", praticamente sem nenhum tratamento. No ocidente, a aplicação de efluentes sanitários em áreas agrícolas se desenvolveu no início do século XIX, principalmente, por volta de 1900, quando a Inglaterra passou a trabalhar esta questão para combater uma epidemia de Cólera.

O caráter mais científico do uso agrícola do lodo de esgoto se desenvolveu no início do século $X X$, sendo que, no exterior, as pesquisas com o resíduo vêm sendo realizadas há bastante tempo. Na década de setenta intensificaram-se essas pesquisas, expandindo-se os conhecimentos científicos sobre o lodo e sobre o processo de tratamento.

Segundo Henry \& Cole (1997), nos primeiros anos da década de setenta, muitos aspectos do uso de biossólido em florestas, incluindo técnicas de aplicação, práticas de manejo e operação e medida dos impactos ambientais, foram investigados. No exterior, vários países já utilizam, rotineiramente, a aplicação de biossólido em ecossistemas agroflorestais como um efetivo método de disposição final do lodo de esgoto. A cidade de Bremerton, no Estado de Washington, vem aplicando biossólido em florestas desde o início da 
década de setenta, sendo que no ano de 1997, 100\% do biossólido foi destinado às florestas do próprio município (Leonard \& McKinney, 1997).

Um fato que incentivou o uso benéfico do bossólido foi a diminuição da disposição em águas marítimas. Segundo Tsutya (2001), essa alternativa, antigamente muito comum em países e cidades costeiras, já está em desuso e, provavelmente, em um futuro bem próximo não haverá mais a disposição oceânica de lodos. O autor cita a assinatura de uma lei pelo Congresso dos Estados Unidos, em 1988, proibindo o lançamento de lodo no mar a partir de 1992 e um acordo, assinado em Helsink, pela maioria dos países, para eliminar a disposição oceânica até 1998.

No Brasil, a experimentação sobre o uso de biossólidos na agricultura acontece desde a década de oitenta. Bettiol \& Carvalho (1982) foram os primeiros pesquisadores brasileiros a publicarem sobre a utilização de lodo de esgoto na agricultura. O surgimento das pesquisas na área florestal ainda é fato mais recente. Em 1998, um grupo de pesquisadores da ESALQ/USP iniciou as primeiras pesquisas em campo sobre a aplicação de biossólidos em culturas florestais no Brasil. O trabalho de Poggiani \& Bennedeti (1999) resume o programa de pesquisa desse grupo e mostra os vários subprojetos que desenvolvidos para verificar a viabilidade ecológica, silvicultural e econômica da utilização do biossólido em cultura de eucalipto. Antes de 1998, foi encontrado apenas um registro na literatura de um trabalho com produção de mudas (Morais et al., 1997).

\subsubsection{Biossólido ou lodo de esgoto?}

Perante a controvérsia que ainda hoje se estabelece no Brasil em torno da definição de biossólido, foi considerado pertinente apresentar uma breve discussão sobre o tema. Muito mais que uma questão de semântica, a utilização de um ou de outro termo pode representar a visão e os conceitos das pessoas que trabalham com o assunto. O termo biossólido passou a ser 
utilizado na maioria dos países e em várias normas no início da década de oitenta, com o objetivo de tirar a conotação pejorativa associada ao termo lodo de esgoto e promover o conceito de que este material não é simplesmente um resíduo e que pode e deve ser reutilizado ou reciclado em sistemas de usos benéficos.

Giller et al. (2002) apresentam uma abordagem interessante sobre a questão do resíduo ou produto, em relação à utilização de resíduos orgânicos em geral, focando o elemento $\mathrm{N}$. Os autores relatam que paradigmas divergentes entre os hemisférios Norte e Sul direcionam tanto a pesquisa como a normatização relacionada ao uso dos "resíduos orgânicos" ou "recursos para a agricultura". Nos países do Norte, termo utilizado para se referir às nações mais industrializadas, as mais recentes pesquisas sobre a ciclagem de $\mathrm{N}$ têm sido focada na possibilidade do excesso de $\mathrm{N}$ causar problemas ambientais. Nos países menos desenvolvidos do Sul, o uso de recursos orgânicos está aumentando e problemas como a pobreza, a eliminação de subsídios e uma infraestrutura deficiente levam a um escasso uso de fertilizantes nitrogenados minerais e reforçam a definição de resíduo orgânico como produto. Nos países mais desenvolvidos, o uso de resíduos orgânicos como produtos foi amplamente desenvolvido, e, apenas mais recentemente, as preocupações com os possíveis efeitos negativos passaram a ser prioridades dentre os temas de pesquisa. Apesar da tendência de seguir o mesmo caminho, o uso de biossólidos no Brasil deveria seguir trajetória inversa. Primeiro, são necessárias pesquisas que garantam que sua utilização não vai causar danos à saúde das pessoas e ao meio ambiente; para, a partir daí regulamentar a aplicação em larga escala. A transformação do resíduo em produto, cuja utilização traga perspectivas de ganhos econômicos para os setores envolvidos com a questão, atualmente é uma estratégia mais efetiva para viabilizar a disposição final do lodo de esgoto do que o convencimento pela questão ecológica e social. Entretanto, o lodo não deveria se transformar em biossólido apenas pela 
confirmação de suas potencialidades em melhorar propriedades do solo e a produtividade das culturas, mas, também, e principalmente, pela garantia de que os riscos são mínimos e inexpressivos.

O lodo de esgoto é o resultado do tratamento dos resíduos líquidos urbanos (domésticos, comerciais e industriais) encaminhados às estações de tratamento de esgoto (ETEs), através das redes coletoras. Durante o tratamento do esgoto, bactérias e outros microorganismos quebram as moléculas orgânicas que servem como fonte de energia para seu desenvolvimento, utilizando os nutrientes para crescerem e se reproduzirem. Quando eles morrem, vão constituir a massa orgânica de lodo. Existem vários sistemas de tratamento, que produzem lodos com características distintas. De acordo com Tsutya (2000), existem basicamente três tipos de lodos oriundos do tratamento de esgotos: primário (lodo bruto produzido nos decantadores primários, com coloração acinzentada, aspecto pegajoso e odor ofensivo), lodo ativado (produzido nos reatores biológicos, com aparência floculenta, coloração marron e odor pouco ofensivo se mantido em condições aeróbias) e lodo digerido (que passou por processo de estabilização biológica, sem odor ofensivo).

Segundo Assunção (1996), a ETE de Barueri produz os três tipos de lodo, que passam por um tratamento terciário gerando um lodo condicionado. Durante essa etapa do tratamento ocorre o condicionamento químico do lodo, que constava, até 2000, da adição controlada de $\mathrm{Ca}(\mathrm{OH})_{2}$ (Cal hidratada) e $\mathrm{FeCl}_{3}$ ao sistema, com dois objetivos principais: 1) provocar a coagulação dos colóides de origem orgânica e inorgânica dispersos no lodo; 2) provocar a precipitação química de metais sob a forma de hidróxidos, óxidos e sais, para sua remoção dos esgotos. $\mathrm{O}$ pH final atingido nesse processo é superior a $11 \mathrm{e}$ as condições físico-químicas são muito propícias à precipitação de hidróxidos de $\mathrm{Fe}$, hidróxidos metálicos diversos, carbonatos de $\mathrm{Ca}$ e $\mathrm{Mg}$ e fosfatos hidratados de Ca. Esse mesmo autor chama a atenção que a grande maioria 
dos trabalhos levantados sobre comportamento ambiental de lodos gerados em ETE's estuda lodos gerados na Europa e Estados Unidos, em estações que empregam apenas os tratamentos primário e secundário. Ele salienta que a ausência do condicionamento químico faz com que esses lodos sejam muito diferentes do resíduo fresco gerado em Barueri. A partir do segundo semestre de 2000, a ETE de Barueri modificou o processo, passando a produzir lodo tratado com polímero e eliminando o condicionamento químico.

Santos \& Tsutiya (1997) prevêem uma produção de $575 \mathrm{t} \mathrm{dia}^{-1}$ de lodo, no ano 2005, considerando somente as estações de tratamento da região metropolitana de São Paulo. Nos Estados Unidos, foi estimada pela U.S. Environmental Protection Agency (USEPA, 1999) uma produção de 6,9 milhões de toneladas durante o ano de 1998. Segundo essa Agência de Proteção Ambiental dos Estados Unidos (USEPA, 1999), o biossólido (historicamente conhecido como lodo de esgoto) deve ter potencial de uso benéfico, especialmente, como corretivo de solo. Miles et al. (1998) e Arnold et al. (1998), também enfocam o uso benéfico do biossólido. Eles afirmam que o lodo deve ser chamado de biossólido quando seu destino final é o uso benéfico como fertilizante e condicionador de solos, aproveitando seu valor como fonte de nutrientes e matéria orgânica para as plantas. De acordo com Poggiani et al. (2000), a Water Environmental Federation, recomenda o uso do termo biossólido para designar o lodo que passa por um tratamento biológico e que apresenta um potencial de uso benéfico em sistemas agroflorestais, sem apresentar riscos à saúde humana e animal. Zhang et al. (2004) salientam que biossólidos não incluem resíduos animais, esgoto não tratado, resíduos sólidos municipais, resíduos perigosos ou resíduos industriais não tratados. Esses autores definem biossólidos como materiais recicláveis que melhoram a fertilidade e a estrutura do solo, aumentando a produção das culturas agrícolas, florestais e hortícolas. 
Para a aplicação do biossólido em determinada área com fins de uso benéfico, devem-se respeitar certos limites de aplicação que garantam segurança na utilização, evitando possíveis problemas, tais como: presença de microorganismos patogênicos, concentrações elevadas de nitrato e metais pesados, atração de vetores como roedores e moscas. Durante a aplicação deve-se garantir a execução das melhores práticas de manejo. De acordo com Miles et al. (1995), essas práticas são métodos operacionais que determinam características da aplicação de biossólido visando proteger o ambiente. Elas incluem taxas de aplicação agronomicamente corretas, limitações devido à declividade e ao pH do solo, zonas tampões, restrições quanto ao acesso público, práticas de conservação do solo e outras restrições locais.

No Estado de São Paulo, foram elaboradas normas para regularizar a utilização do biossólido (Companhia de Tecnologia e Saneamento Ambiental, 1999). Segundo a norma da CETESB o termo biossólido refere-se exclusivamente ao lodo resultante do sistema de tratamento biológico de despejos líquidos sanitários, com características tais que atendam as condições da norma para uma utilização segura na agricultura.

Nos Estados Unidos, durante o ano de 1998, 60\% do biossólido produzido teve uso benéfico, sendo $41 \%$ aplicado no solo para favorecer o desenvolvimento da vegetação, incluindo as florestas (USEPA, 1999).

\subsubsection{Possíveis problemas}

Um aspecto que dificulta a generalização do uso de biossólidos é a variação existente em sua composição. Essa variação ocorre, principalmente, devido aos diferentes processos e graus de tratamento. Em cada ETE podem ser produzidos vários tipos de lodo (primário, secundário e terciário), submetidos a diferentes mecanismos de adensamento, estabilização, condicionamento e desaguamento. Além disso, as características do lodo podem variar em função do tipo de esgoto, que vai depender das condições de 
vida da população geradora e da proporção entre esgoto domiciliar e industrial. A qualidade do lodo está intimamente relacionada ao nível sócio-cultural da população e ele apresenta composição química bastante heterogênea em função da origem das matérias-primas constituintes (Fortuny \& Fuller, 1979).

Sob o ponto de vista nutricional, o biossólido pode não ser um material bem balanceado. O K é um elemento que sempre apresenta teores baixos na composição do resíduo, pois é muito solúvel e se perde com o efluente, sem ficar retido em sua massa orgânica. Apesar do biossólido, geralmente, ser rico em matéria orgânica, N, P, Ca e micronutrientes, a proporção entre os nutrientes pode não ser a adequada para a espécie. Como um dos critérios para calcular a dose ótima de aplicação é a relação entre a quantidade de $\mathrm{N}$ recomendada para a cultura e a quantidade de $\mathrm{N}$ disponível no biossólido (CETESB, 1999), biossólidos com elevados teores de $\mathrm{N}$ podem levar a baixas doses de aplicação e a diminuição do potencial de utilização de outros nutrientes. Além disso, a competição por sítios de absorção e/ou reações entre as formas iônicas dos elementos podem diminuir a absorção de alguns pelas plantas. A lenta mineralização do biossólido também pode ser prejudicial, sob o ponto de vista nutricional e produtivo, pois a conseqüente liberação dos nutrientes pode não ocorrer no momento em que a cultura mais necessita. Desse modo, em certos casos, torna-se necessária uma complementação com fertilizantes minerais, para compensar esta lenta mineralização do biossólido e melhorar a fertilidade dos solos e a nutrição das plantas. O balanceamento do biossólido com fertilizantes minerais deve ser específico para determinada cultura, local de aplicação e tipo de biossólido.

A presença de poluentes como os metais pesados, que é uma das maiores preocupações durante o desenvolvimento das pesquisas sobre o uso de biossólidos, está, em geral, associada à ocorrência de despejos industriais no esgoto. Segundo Berton (2000), os metais pesados são definidos como os elementos químicos com densidade maior que $5 \mathrm{~g} \mathrm{~cm}^{-3}$. Utilizando essa 
definição, são incluídos como metais pesados alguns elementos que são essenciais às plantas, aos animais e ao homem, tais como zinco ( $\mathrm{Zn}$ ) e cobre (Cu). Entretanto, se ingeridos em quantidades elevadas esses elementos apresentam alta toxicidade, colocando em risco a saúde humana e animal (Andrade, 1999). Segundo Tiller \& Mcbride (1989), o termo metal pesado pode também ser usado como uma denominação globalizada, utilizada para os elementos classificados como poluentes ambientais. Essa classificação envolve tanto elementos metálicos, como semi-metálicos e não metálicos. A ocorrência de problemas com metais vai depender não só da concentração, mas também da espécie química presente, que varia em função de fatores como o pH e o potencial de óxido-redução. O efeito a longo prazo dos metais pesados no ambiente não é completamente conhecido e entendido. Através da absorção pelas plantas, que alimentarão os herbívoros, os metais podem entrar na cadeia alimentar, chegando aos consumidores de primeira ordem e ao homem. Segundo Chaney (1990), a captura pelas plantas é a principal maneira dos metais entrarem na cadeia alimentar. Os valores de metais pesados em lodo de esgoto variam bastante. Ao longo dos últimos anos, no lodo produzido na ETE de Barueri, o elemento que tem causado maior preocupação é o níquel, chegando inclusive a ultrapassar o limite permitido (Tabela 1). 
Tabela 1. Comparação das concentrações de metais pesados nas tortas das ETE de Barueri com o teto para uso agrícola vigente nos EUA desde 19/2/93 e adotado pela CETESB na norma P.430 (modificado de SANTOS \& TSUTIYA, 1997)

\begin{tabular}{cccc}
\hline ELEMENTO & $\begin{array}{c}\text { TEOR MÉDIO* } \\
\text { (CV) }\end{array}$ & $\begin{array}{c}\text { TEOR MÁXIMO } \\
\text { OBSERVADO }\end{array}$ & $\begin{array}{c}\text { TETO } \\
\text { ACEITÁVEL }\end{array}$ \\
\hline Cd & $21(43 \%)$ & 38 & 85 \\
Pb & $200(40 \%)$ & 322 & 840 \\
$\mathbf{C u}$ & $917(47 \%)$ & 1706 & 4300 \\
$\mathbf{C r}$ & $169(35 \%)$ & 984 & 3000 \\
$\mathbf{H g}$ & $2(97 \%)$ & 7 & 57 \\
$\mathbf{N i}$ & $364(32 \%)$ & 600 & 420 \\
$\mathbf{Z n}$ & $1876(35 \%)$ & 2506 & 7500 \\
\hline
\end{tabular}

*média de 11 amostras coletadas de 1993 a 1996

Carvalho (2001) confirma que já aconteceu, em algumas ocasiões, a extrapolação dos limites permitidos para níquel e arsênio no lodo da ETE de Barueri. No entanto, o autor ressalta que este fato não ocorreu nos últimos anos, o que indica um monitoramento adequado no que se refere ao teor de metais pesados no esgoto afluente à ETE de Barueri. Atualmente, os teores de metais no lodo gerado em Barueri diminuíram bastante, como pode ser observado na caracterização do material utilizado neste trabalho (Tabela 4), resultado principalmente da política de controle na fonte geradora, que tem levado as indústrias a tratarem seus efluentes, com o conseqüente descarte de uma água residuária de melhor qualidade na rede coletora.

Outro aspecto que nem sempre é considerado, mas de suma importância quando se cogita o uso agroflorestal do biossólido, diz respeito ao nitrogênio (N) aplicado via resíduo. Em função da taxa de mineralização do $N$ (TMN), que é dependente de características do biossólido e características edafoclimáticas do 
local onde é aplicado, pode haver movimentação de nitrato no perfil do solo e conseqüente contaminação de águas subterrâneas. O comportamento do $\mathrm{N}$ aplicado via resíduos orgânicos, em geral, ou biossólidos, em particular, tem sido pouco estudado em solos ácidos e muito intemperizados (Andrade, 1999). De acordo com Robinson et al. (2002), o N é liberado do biossólido na forma inorgânica, diretamente do componente inorgânico ou através da mineralização. Os autores afirmam que existe pouca evidência na literatura de lixiviação de $\mathrm{N}$ orgânico de biossólidos. Se a taxa de liberação de $\mathrm{N}$ do biossólido for além da capacidade assimilativa do ecossistema, pode ocorrer a contaminação das águas superficiais e subterrâneas. É desejável, portanto, que o sistema radicular da vegetação onde o biossólido é aplicado possa absorver e reter em sua fitomassa o $\mathrm{N}$ liberado durante o processo de decomposição.

Os organismos patogênicos podem causar doenças, tanto nas pessoas que lidam com o material quanto nas plantas cultivadas. Eles podem ser agrupados em ovos de vermes, bactérias, quistos de protozoários e vírus (FAO, 1978). As limitações quanto à quantidade de organismos patogênicos são utilizadas para classificar o biossólido como classe "A" ou "B". O biossólido classe "A" passa por processos de higienização que garantem, praticamente, a inexistência de patógenos, sendo inclusive liberado seu uso em áreas públicas como praças e jardins. No entanto, essa classificação se baseia apenas na determinação de coliformes fecais e salmonelas, não sendo considerados patógenos como ovos de helminto, normalmente mais resistentes à higienização, e vírus e bactérias veiculados via esgoto, causadores de doenças como leptospirose e hepatite. A grande variedade de microorganismos presentes no esgoto, vários deles com potencial de causar danos à saúde humana quando presentes em uma dose mínima infectante, faz com que um excelente processo de desinfecção seja fundamental e absolutamente imprescindível quando se pensa em utilizar o lodo de esgoto como biossólido, principalmente em culturas destinadas à produção de alimentos. 
Outro possível problema, que ainda não está sendo considerado nas pesquisas sobre o uso de biossólido realizadas no Brasil, é a presença de contaminantes orgânicos. Dentre o grande número de substâncias orgânicas que podem causar impacto negativo ao ambiente e ao homem, destacam-se o grupo das befenilas policloradas (PCBs) e o grupo dos hidrocarbonetos aromáticos policíclicos (PAHs). As befenilas são substâncias organocloradas apolares, de fácil absorção pelas plantas, através das quais podem entrar na cadeia alimentar humana. Os hidrocarbonetos são resultantes da oxidação incompleta de substâncias orgânicas e causam preocupação por serem carcinogênicas. Ambos os grupos, são constituídos por estruturas muito persistentes no solo.

Vale ressaltar que a falta de aceitação pública da utilização de biossólidos, tanto por parte dos produtores quanto por parte dos consumidores finais dos produtos cultivados com o resíduo, pode ser um grande problema para a viabilidade da atividade. O lodo que sai das estações de tratamento normalmente apresenta aspecto visual e odor desagradáveis. Além disso, o repúdio existente pelos nossos próprios dejetos, inexistente para estercos de outros animais, pode prejudicar a aceitação por parte dos produtores e a comercialização de um produto que tenha sido cultivado utilizando biossólido. A cultura existente no meio rural de que o material do lodo de esgoto não é adequado para a agricultura pode ser uma séria dificuldade. Problemas como, por exemplo, o ocorrido recentemente no Distrito Federal, onde foi implantada a "máfia do lodo" (Folha de São Paulo, 2003), podem comprometer a credibilidade e colocar em risco o desenvolvimento do programa de uso agroflorestal do biossólido. Pessoas ligadas à "máfia do lodo", denunciada após a ocorrência de um caso de contaminação de nascente de água com Salmonela, retiravam o lodo da ETE da CAESA, distribuído gratuitamente, e o vendiam indiscriminadamente e sem nenhum controle para os produtores. Assim, uma etapa essencial para o sucesso da implantação do uso benéfico do 
biossólido em culturas agroflorestais é a logística e controle da distribuição, em conjunto com uma campanha de conscientização séria, que respeite as individualidades de cada região e da população. As unidades geradoras de lodo devem desenvolver um adequado sistema de gerenciamento que garanta que o material saído das ETEs chegue ao destino final planejado e seja utilizado segundo as boas práticas de manejo e seguindo projeto elaborado por responsável técnico.

\subsubsection{Benefícios}

A utilização de lodo de esgoto como biossólido, aproveitando seu potencial fertilizante e condicionador de solos para promover o crescimento de plantas, representa a possibilidade de associar ganhos para o produtor, através do aumento da produtividade das culturas e redução do uso de fertilizantes minerais, com vantagens inclusive para os geradores de lodo, através da efetivação de métodos adequados e mais econômicos de disposição final desse resíduo.

Normalmente, a aplicação de biossólido nos solos promove sua valorização devido a transformações, na maioria das vezes positivas, sobre suas propriedades químicas, físicas e biológicas. Do ponto de vista químico, quando biossólidos, principalmente aqueles alcalinos, reagem com o solo, pode ocorrer aumento do pH e diminuição da acidez, assim como aumento da CTC e da disponibilidade de macro e micronutrientes, melhorando a sua fertilidade. Em solos tropicais muito intemperizados, onde a capacidade de troca catiônica (CTC) é extremamente dependente da MO, o uso agrícola de biossólidos é ainda mais atrativo (Melo et al., 1994). Em geral, o produto final do tratamento do esgoto é rico em matéria orgânica e pode fornecer $\mathrm{N}$ às plantas em quantidades satisfatórias, além de outros elementos como $\mathrm{P}, \mathrm{S}, \mathrm{Ca}$ e micronutrientes. Do ponto de vista das propriedades físicas, o biossólido, pelo efeito da matéria orgânica nele contida, pode funcionar como condicionador de 
solos e refletir em melhoria da estrutura física, aumentando a agregação das partículas (estabilidade de agregados), favorecendo a infiltração de água no perfil, a aeração e a retenção de umidade e diminuindo as perdas por erosão (Sabey, 1974; Carvalho \& Barral, 1981; Zhang et al., 2004). No trabalho de Melo et al. (2004), os autores encontraram que a incorporação anual de biossólido em Latossolo Vermelho distrófico (LVd) textura média e Latossolo Vermelho eutroférrico argiloso, cultivados com milho por cinco anos, aumentou a macroporosidade nos dois solos e reduziu a densidade no LVd.

A ação cimentante da matéria orgânica é o principal agente modificador da porosidade e da agregação do solo. Segundo Marciano (1999), além da ação cimentante do biossólido é importante considerar o "efeito mistura", que significa a transferência ao solo de suas características intrínsecas determinadas pela sua própria constituição. A ação cimentante e o "efeito mistura" atuam simultaneamente e a predominância de um sobre o outro vai depender da quantidade de biossólido, sendo que, quanto maior é a dose aplicada, mais evidente é a ação do "efeito mistura".

Vários trabalhos relatam ganhos na produtividade de culturas agrícolas (Bettiol et al., 1982; Boaretto et al., 1992; Ros et al., 1993; Simonete, 2003) e de plantações florestais (Weetman et al., 1993; Polglase \& Myers, 1995, Kaposts et al., 2000; Vaz \& Gonçalves, 2002). Nas atividades agrícolas, com a aplicação do biossólido no solo ocorre a reciclagem de nutrientes para os vegetais, com economia de fertilizantes, tornando mais sustentável o sistema de produção (Carvalho \& Barral, 1981). O aumento da produtividade das culturas normalmente acontece concomitantemente com a melhoria da fertilidade do solo e do estado nutricional das plantas. No trabalho de Melo et al. (2001), pode-se observar que vários outros autores, trabalhando com diferentes biossólidos, em diferentes condições e culturas, também detectaram efeito positivo sobre a fertilidade de solos e a nutrição de plantas. 
Do ponto de vista ecológico, desde que assegurada a qualidade do lodo em termos de possíveis contaminantes, seu uso como biossólido, por promover sua reciclagem, é uma das mais corretas dentre as várias alternativas de disposição final. Segundo Poggiani et al., (2000), além de representar benefício econômico, o uso agrícola de biossólidos representa benefício ecológico, pelo retorno ao campo de parte da matéria orgânica, nutrientes e energia exportados para os centros urbanos. Outro importante benefício ambiental é a possibilidade de aumento do estoque de carbono no solo e amenização do efeito estufa (Gibson et al., 2002).

Do ponto de vista social, é um importante benefício para as grandes cidades, por criar uma forma de saída para um dos resíduos mais problemáticos gerados nas áreas urbanas. Além disso, com o uso do biossólido há a possibilidade de beneficiar os produtores rurais através do aumento da produtividade das culturas e economia de fertilizantes, e evitar a contaminação de pessoas devido a uma disposição inadequada do lodo.

\subsubsection{Utilização em florestas}

As alternativas mais usuais para o aproveitamento e/ou destino final de lodos/biossólidos têm sido as seguintes: uso agrícola, disposição em aterro sanitário, reuso industrial, incineração, conversão do lodo em óleo combustível, recuperação de solos, "landfarming" e disposição oceânica (Tsutya, 2000). Esse autor cita o uso em florestas como uma alternativa interessante junto às culturas mais recomendadas (milho, trigo, cana e sorgo), sendo incluído como uso agrícola. No entanto, Tsutya (2001) já considera a aplicação em plantações florestais como alternativa à parte do uso agrícola.

A aplicação de biossólido em plantações florestais apresenta uma série de vantagens em comparação com sistemas agrícolas. Hart et al. (1988), citando vários outros autores, resumem essas vantagens. Os produtos das culturas florestais, normalmente não são comestíveis, diminuindo o risco quanto 
à entrada de possíveis contaminantes na cadeia alimentar. As florestas respondem à aplicação de biossólido com significativos aumentos de biomassa e de nutrientes absorvidos. Os ciclos das culturas florestais são mais longos e a acumulação de biomassa durante esse período pode ser uma maneira de retirar do solo e armazenar certos elementos perigosos, que podem ser exportados do local com a colheita da madeira. Os solos florestais são geralmente pobres, resultando em melhor aproveitamento e menores perdas dos nutrientes. As culturas florestais oferecem menor oportunidade de contato humano com biossólido recém aplicado. Além disso, o ciclo longo permite maiores intervalos e uma maior dinâmica entre aplicações. Diferentemente de uma cultura agrícola, na qual a aplicação deve ocorrer em uma determinada época; em uma plantação florestal, a qualquer momento seria possível entrar no povoamento para realizar a distribuição do resíduo. O sistema radicular perene e bem distribuído dos eucaliptos, forma um verdadeiro emaranhado de raízes finas na camada mais superficial do solo que aumenta a eficiência de absorção dos elementos e pode funcionar como um verdadeiro filtro para evitar, por exemplo, a lixiviação de nitrato. Dessa maneira, os nutrientes do biossólido, liberados de forma mais lenta, podem ser melhor aproveitados pelas árvores, com menores perdas por lixiviação ou escorrimento superficial.

Segundo Smith \& Carnus (1997), a aceitação internacional da utilização de biossólidos em florestas aumentou ao longo das últimas décadas devido aos numerosos estudos de campo que viabilizaram o desenvolvimento de uma forte base teórica e prática para sistemas de aplicação ambientalmente aceitáveis e devido às várias publicações que permitiram a organização do planejamento e "design" da aplicação. Especificamente, em relação à cultura de eucalipto, foram encontradas poucas referências na literatura internacional, publicadas em países como Austrália, Nova Zelândia e Egito. No Egito, El-Baha (2001) encontrou efeito positivo do biossólido sobre o crescimento de Eucalyptus camaldulensis. No Brasil, o grupo de pesquisadores da ESALQ/USP, 
atualmente é o único que vem publicando (Andrade, 1999; Andrade \& Mattiazzo, 2000; Faria, 2000; Faria \& Rodriguez, 2000; Fortes Neto, 2000; Poggiani et al., 2000; Vaz, 2000; Vaz \& Gonçalves, 2002; Guedes, 2000; Martins, 2002; Rocha, 2002; Guedes \& Poggiani, 2003; Soares, 2003; Andrade, 2004; Velasco-Molina, 2004) sobre a utilização de biossólido em plantio de eucalipto. Segundo Faria \& Rodrigues (2000), o potencial de uso do biossólido da ETE de Barueri (SABESP) em áreas reflorestadas próximas à estação é muito grande. Os autores concluíram também que existe demanda para o uso de biossólido como fertilizante em plantios de Eucalyptus e Pinus no Estado de São Paulo, baseado no levantamento da BRACELPA (1999) que indicava a existência de uma área reflorestada de aproximadamente 321.000 ha, no final de 1999. Em trabalho mais recente, realizado pelo Instituto Florestal do Estado (Kronka et al., 2003), pode-se observar que a área plantada aumentou nos últimos anos e que existe um total de 770.010 hectares de reflorestamentos com Pinus e Eucalyptus em São Paulo. Como a produção de lodo não deve ter aumentado nessa mesma velocidade, a potencialidade dos reflorestamentos em consumir o lodo de esgoto produzido no Estado deve ter aumentado ainda mais.

De maneira geral, tanto na Europa quanto na América do Norte e na Austrália, existem diversas pesquisas com respostas favoráveis das espécies florestais de interesse silvicultural, principalmente do gênero Pinus, à adição de biossólido ( McNab \& Berry, 1985; Phillips et al., 1986; Hart et al., 1988; Weetman et al., 1993; Polglase \& Myers, 1995, Kaposts et al., 2000).

Henry et al. (1993) conduziram estudos durante vinte anos em uma floresta experimental localizada em Washington (EUA), confirmando a grande potencialidade de biossólidos para aumentar a produtividade de muitas áreas florestais. Esses estudos mostraram claramente que a aplicação de biossólidos, em quantidades ambientalmente aceitáveis, resulta em elevadas taxas de resposta de crescimento, tanto para plantios jovens, como para áreas bem 
estabelecidas. A resposta do crescimento à aplicação do biossólido é, tipicamente, maior e mais duradoura quando comparada com fertilização mineral. Diversos experimentos realizados nesse Estado assinalam que a aplicação do lodo beneficia os sítios florestais através de um resultado imediato que pôde ser constatado pelo crescimento das árvores e da vegetação do subbosque e, a longo prazo, pelo aumento da produtividade do sítio (Henry et al., 1994).

Labrecque et al. (1995) aplicaram seis doses de lodo estabilizado, desidratado e granulado, de forma a obter 0, 40, 80, 120, 160 e $200 \mathrm{~kg} \mathrm{~N}$ disponível ha ${ }^{-1}$, em grandes potes plásticos contendo solo arenoso e cultivados com duas espécies do gênero Salix durante vinte semanas. A maior dose testada provocou o melhor desenvolvimento, em ambas espécies. O coeficiente de transferência de metais não variou entre espécies, mas foi, significativamente, maior para cádmio e zinco. As plantas absorveram mais cádmio e zinco, mas foram menos hábeis para absorver níquel, mercúrio, cobre e chumbo. Eles afirmam que um conteúdo elevado de metais em culturas agrícolas não é desejável, além de ser potencialmente perigoso. No entanto, para árvores isso é aceitável, desde que a atividade fisiológica não seja afetada. Assim, as plantações florestais podem ser usadas como filtros, através da captura, acúmulo e armazenamento de poluentes dentro da biomassa. Isso vai variar com a cultura florestal, pois existe uma captura seletiva de metais, provavelmente devido a solubilidades diferentes no solo e preferência de determinada espécie vegetal por diferentes metais.

Fiskell et al. (1990) relatam baixa concentração de metais em plantio de Pinus elliottii var. elliottii e no sub-bosque, após aplicação de até $22 \mathrm{Mg} \mathrm{ha}^{-1} \mathrm{de}$ biossólido em solo arenoso. Dos metais remanescentes no horizonte orgânico, somente zinco e cádmio apresentaram alguma quantidade na forma trocável, sendo que apenas o zinco foi acumulado em quantidade apreciável na planta. 
Em Vancouver (Canadá), árvores tratadas com fertilizantes inorgânicos sofreram deficiência de enxofre, enquanto áreas tratadas com lodo de esgoto não apresentaram essa deficiência (Weetman et al., 1993).

Em uma área dos EUA, cultivada com Abies grandis e Pseudotsuga menziesii, oito anos após a aplicação de $300 \mathrm{Mg} \mathrm{ha}^{-1}$ (peso seco) de biossólido, houve sintomas de deficiência de Mg (Harrison et al., 1994 a). Nessa área, apesar dos níveis de metais serem, significativamente, maiores para níquel, cádmio e crômio nas folhas das árvores plantadas na área tratada, as concentrações não atingiram níveis considerados tóxicos.

Foram encontrados na literatura poucos trabalhos relatando, especificamente, o efeito da aplicação de biossólido sobre a ciclagem de nutrientes em plantações florestais. Guedes (2000) estudou, em condições de campo, o efeito do biossólido produzido na ETE de Barueri (SP), onde o lodo é tratado/estabilizado com cal, sobre a ciclagem de nutrientes, verificando alterações significativas nos teores de nutrientes nas folhas das árvores de eucaliptos que receberam o produto, sobre a taxa de retorno de folhedo senescente e nutrientes ao solo e sobre a taxa de decomposição.

\subsection{O cultivo de eucalipto}

Segundo o editorial e o relatório da Comissão Temática 01 (Benefícios sociais, ambientais e econômicos da atividade florestal) do $8^{\circ}$ Congresso Florestal Brasileiro realizado em 2003, as florestas do Brasil ocupam uma área aproximada de 450 milhões de hectares, sendo que a atividade de base florestal contribui com $4 \%$ do PIB e $10 \%$ das exportações totais, proporcionando 2 milhões de empregos diretos e indiretos. No âmbito econômico, o setor aporta cerca de US\$23 bilhões anuais à economia brasileira, contribui com US $\$ 5,6$ bilhões às exportações, produz saldo líquido positivo de US\$4,0 bilhões. $O$ subsetor de papel e celulose, alimentado pelos reflorestamentos, responde por 
aproximadamente metade do valor anualmente exportado. Internamente, o setor recolhe $\mathrm{R} \$ 4,0$ bilhões em impostos.

Em São Paulo, segundo levantamento recentemente realizado pelo Instituto Florestal do Estado (Kronka et al., 2003), existe um total de 770.010 hectares de reflorestamentos com Pinus e Eucalyptus, correspondendo a 3,1\% do total da área territorial do Estado de São Paulo, onde 611.516 ha correspondem às áreas com Eucalyptus $(79,4 \%)$ e 158.494 ha $(20,6 \%)$ com Pinus. A Região Administrativa de Sorocaba concentra 326.070 hectares, correspondendo a 42,3\% de toda a área reflorestada em São Paulo. Essa é a região de reflorestamento mais expressiva do Estado, seguida de Campinas (110.005 ha - 14,3\%), Ribeirão Preto (97.055 ha - 12,6\%), Vale do Paraíba ( 75.425 ha $-9,8 \%)$ e Bauru (67.237 ha $-8,7 \%)$. Do total de reflorestamento com Eucalyptus (611.516 ha), predominam as espécies E. grandis (159.249 ha) e E. saligna (92.217 ha).

As importâncias econômica, social e ambiental dos reflorestamentos, perante a pequena área ocupada por eles no Estado, desabona as críticas, que, ainda hoje, freqüentemente são veiculadas nos mais diversos setores da sociedade. A referência aos reflorestamentos como "desertos verdes" e o senso comum de que o eucalipto seca e empobrece o solo, refletem um desconhecimento técnico-científico sobre questões já esclarecidas. A falta de conhecimento sobre essa espécie florestal já provocou muita polêmica. No entanto, a experiência acumulada em décadas de plantio e os avanços da pesquisa dizimaram grande parte das dúvidas. Por exemplo, a afirmação de que o eucalipto seca o solo já foi refutada por autores como Lima (1993) e Novais et al. (1996), que mostraram que o eucalipto comporta-se de forma similar a outras espécies florestais no que diz respeito à dinâmica da água no solo e da água subterrânea; que os plantios de eucalipto no Brasil consomem a mesma quantidade de água que as florestas nativas; e que o eucalipto é mais eficiente no uso da água quando comparado a outras culturas agrícolas. 
A afirmação de que os monocultivos florestais diminuem a biodiversidade só faz sentido quando analisada em uma escala local, sem considerar a pequena área ocupada por estes plantios perante uma escala mais ampliada e sem considerar que a elevada produtividade das culturas florestais tem um efeito direto de diminuição da pressão sobre as florestas nativas. Como seria atendida a demanda - real, crescente e de difícil substituição - por madeira no Brasil, se não fossem os reflorestamentos?

O Eucalyptus grandis W. Hill (ex Maiden) é uma espécie originária das regiões sudeste e nordeste da Austrália. Essa é uma das mais de seiscentas espécies do gênero.

As plantações de eucalipto manejadas em curta rotação apresentam dois períodos de crescimento: 1) uma fase juvenil até o fechamento das copas, durante a qual a extração de nutrientes das reservas do solo atende a maior parte do que é requisitado pelas árvores no período; 2) outra fase antes da colheita, caracterizada por intensa reciclagem dos nutrientes, seja através da retranslocação interna ou através da mineralização da matéria orgânica retornada ao solo com a queda de serapilheira (Laclau et al., 2003). No trabalho desenvolvido por esses autores, a extração máxima de nutrientes do solo ocorreu no segundo ano de crescimento, para todos os elementos analisados. A retranslocação interna supriu $60 \%$ do requerimento por $\mathrm{K}, 30-40 \%$ para $\mathrm{N}$ e $\mathrm{P}$, considerando a média dos quatro primeiros anos do povoamento.

\subsection{Ciclagem de nutrientes}

Neste trabalho a ciclagem de nutrientes está sendo analisada considerando dois aspectos. Um aspecto dinâmico ao longo do tempo, com base na avaliação de taxas de transferência interna de nutrientes e outro, estático e pontual, com base na avaliação dos estoques de nutrientes em compartimentos do ecossistema, cinco anos após a instalação do experimento. 
De acordo com a teoria dos ecossistemas, os sistemas vivos são controlados mais por relações dinâmicas do que por rígidas estruturas mecânicas, sendo que as taxas de trocas ou transformações são mais importantes do que os estoques. As transferências internas levam a uma circulação de nutrientes dentro de um ecossistema florestal sempre maior do que as entradas recebidas de fora do sistema (Schlesinger, 1991). Quanto mais prolongado o tempo de reciclagem, mais conservativo pode ser considerado o ecossistema.

A floresta, quando em equilíbrio, reduz ao mínimo a saída de nutrientes do ecossistema, através da interação solo-vegetação. Desta forma, o solo pode manter o mesmo nível de fertilidade, ou até melhorar suas características ao longo do tempo. A floresta não perturbada, de forma geral, apresenta uma grande estabilidade, ou seja, os nutrientes introduzidos no ecossistema pela chuva e intemperismo geológico estão em equilíbrio com os nutrientes perdidos para os rios e o lençol freático. Os nutrientes, uma vez introduzidos no ecossistema, podem reciclar por tempo mais ou menos prolongado, dependendo da eficiência da ciclagem bioquímica e biogeoquímica.

O caso das florestas de rápido crescimento é diferente. A retirada da biomassa florestal de forma sistemática e por cortes rasos age como um elemento de desequilíbrio nutricional no ecossistema (Poggiani, 1985) e há necessidade de um monitoramento contínuo para garantir sua sustentabilidade ecológica e econômica. Segundo Poggiani et al. (2000), a sustentabilidade de uma plantação florestal está diretamente relacionada, além de outros fatores, com o balanço nutricional do ecossistema. Em outras palavras, a médio e longo prazos, a quantidade de nutrientes essenciais para o crescimento das árvores, que entra na plantação florestal, deve ser equivalente à quantidade que sai do ecossistema devido à colheita florestal, à lixiviação e aos processos erosivos. Se este balanço não for assegurado, não haverá sustentabilidade a longo prazo. As principais fontes de entrada de nutrientes no ecossistema florestal são: a poeira, a chuva, o intemperismo das rochas, a fixação biológica de 
nitrogênio e a aplicação de fertilizantes e resíduos orgânicos urbanos ou agroindustriais. As perdas de nutrientes são ocasionadas pelos processos de erosão e lixiviação, pela água de drenagem, fogo, processos de denitrificação e principalmente pela colheita florestal (Vital, 1996; Poggiani \& Schumacher, 1997). Vital et al. (1999), estudando a ciclagem de nutrientes em plantio de eucalipto no Estado de São Paulo, verificaram que as saídas de nutrientes através da exploração da biomassa lenhosa representaram 66\% do N, 81\% do $\mathrm{P}, 70 \%$ do $\mathrm{K}, 80 \%$ do $\mathrm{Ca}$ e $76 \%$ do $\mathrm{Mg}$, em relação ao total de nutrientes que estavam estocados nas árvores. Essa exportação de nutrientes que ocorre quando se pratica o corte raso de uma cultura florestal exige que, de alguma forma, os nutrientes sejam repostos, para que a fertilidade do solo e a produtividade da área não sejam comprometidas.

A retranslocação de nutrientes de tecidos senescentes para os tecidos mais jovens da árvore pode suprir grande parte de sua demanda nutricional, especialmente, por nutrientes móveis dentro da planta, como: nitrogênio, enxofre, fósforo e potássio, diretamente envolvidos na dinâmica dos processos fisiológicos (Landsberg \& Gower, 1997).

\subsubsection{O ciclo biogeoquímico}

Além das entradas e saídas do ecossistema consideradas durante o balanço geoquímico, é preciso compreender as transformações internas que acontecem, ou seja, os ciclos biogeoquímicos. A floresta modifica a química da precipitação quando a água passa através das copas ou escorre pelos lenhos das árvores. Além disso, ocorre a deposição de material orgânico senescente (folhas, galhos, cascas, frutos) que vai formar a manta florestal (serapilheira), cuja decomposição, assim como, das raízes e organismos, libera novamente os nutrientes tornando-os disponíveis para as plantas, através da mineralização da matéria orgânica do solo. De acordo com Carpanezzi (1980), o retorno de nutrientes ao solo é efetuado por cinco componentes: a deposição de material 
orgânico, a lavagem foliar ou das copas, a lavagem por escoamento pelo tronco, a produção de exsudados pelas raízes e a morte de raízes. A deposição de material orgânico é considerada, tradicionalmente, como o mais importante modo de transferência de nutrientes da vegetação ao solo. Além disso, o material orgânico depositado permite a existência de uma grande variedade de nichos para a fauna e é fonte para a matéria orgânica coloidal dos solos.

As plantações florestais de rápido crescimento, como, por exemplo, os eucaliptos, crescem incorporando na biomassa aérea, além do CO2 fixado do ar, também os nutrientes minerais absorvidos do solo. Parte da biomassa produzida, após certo tempo, se deposita sobre o solo formando a manta florestal (serapilheira). A decomposição desta libera novamente os nutrientes tornando-os disponíveis para as plantas. É esta reciclagem contínua que permite grande acúmulo de biomassa florestal, mesmo em solos de baixa fertilidade. Segundo Binkley et al. (1992), espécies eficientes em produzir elevadas quantidades de fitomassa por unidade de nutriente, tipicamente, produzem serapilheira de qualidade inferior.

Cerca de $70 \%$ da serapilheira produzida por um talhão florestal jovem é composta por folhas senescentes (folhedo). Sua formação segue uma sazonalidade em função das condições climáticas ao longo do ano e sua decomposição também é influenciada pela variação de umidade e temperatura, ocorrendo com maior intensidade em períodos quentes e úmidos (Poggiani \& Schumacher, 1997).

A quantidade de nutrientes na serapilheira depende da espécie, da proporção de folhas em relação aos outros componentes, da ciclagem bioquímica (capacidade de translocação dos nutrientes dentro da árvore antes da senescência e queda das folhas), bem como do tipo de solo (Schumacher \& Poggiani, 1993). No trabalho desenvolvido por Laclau (2003), foi observado que as folhas senescentes continham mais de $75 \%$ de nutrientes retornados ao solo, independente do nutriente. 
Quando todos os fluxos de entrada e saída de nutrientes de um compartimento do ecossistema são medidos ou calculados, o balanço entre entradas e saídas mostra a direção real da mudança na fertilidade do solo; cuja manutenção ou, se possível, elevação deve ser o objetivo maior do manejo florestal sustentável (Ranger \& Turpault, 1999). Esses autores consideram dois componentes para a fertilidade química do solo. Um componente de curto prazo, representado pelos nutrientes disponíveis para nutrição de plantas, caracterizado pela análise de terra que é rotineiramente utilizada, e outro componente de médio a longo prazo, caracterizado pelos fluxos dos elementos fornecidos pelo intemperismo e pela deposição atmosférica. O equilíbrio dinâmico dos fluxos, que caracteriza o segundo componente através do balanço algébrico entre entradas e saídas durante uma mesma escala temporal, é mais interessante do que a análise da terra, que é um parâmetro estático. O mais adequado do ponto de vista ecológico são fluxos balanceados ou balanços positivos, desde que o acúmulo do elemento não seja elevado o suficiente para causar injúrias, saturação ou eutrofização do sistema e desbalanceamentos nutricionais.

\subsubsection{O processo de decomposição e a liberação de nutrientes}

Um ponto crucial da ciclagem dos elementos minerais está centrado no processo de decomposição da serapilheira, principal mecanismo através do qual nutrientes e substâncias orgânicas são reintegrados aos solos florestais (Aber \& Melillo, 1980). Durante o processo de decomposição, tanto a biomassa quanto as características bioquímicas da serapilheira mudam, sendo regulados pela interação de três componentes: o ambiente físico-químico, a qualidade do recurso em decomposição e os organismos decompositores (Attiwill \& Adams, 1993). Camargo et al. (1999), citando vários autores, explicam as fases da decomposição dos resíduos orgânicos. A fase inicial da biodegradação microbiana é caracterizada pela perda rápida dos compostos orgânicos 
prontamente decomponíveis (açúcares, proteínas, amido, celulose, etc.). $\mathrm{Na}$ fase subsequente, produtos orgânicos intermediários e protoplasma microbiano, recentemente formado, são biodegradados por uma grande variedade de microorganismos com produção de nova biomassa e liberação de $\mathrm{CO}_{2}$. O estágio final é caracterizado pela decomposição gradual de compostos mais resistentes, exercida pela atividade de actinomicetos e fungos.

A reciclagem de nutrientes ocorre em três fases sequenciais: i) uma fase inicial de liberação de nutrientes através da lixiviação; ii) uma fase de imobilização líquida, durante a qual os nutrientes são retidos ou importados pelos microorganismos decompositores; iii) uma fase de liberação, durante a qual os nutrientes são liberados da serapilheira, normalmente em uma taxa proporcioanal à taxa de perda de massa (Berg \& Staaf, 1981). No entanto, segundo Prescott et al. (1993a), o modelo de imobilização ou liberação varia entre espécies e ecossistemas, sendo que algum tipo de serapilheira em particular pode não apresentar todas as três fases.

Bubb et al. (1998) estudaram, na Austrália, a decomposição de acículas de liteira de Araucaria e encontraram forte correlação da taxa de perda de biomassa do material com indicadores de sua qualidade, como teor de $\mathrm{N}$, lignina e polifenóis. Eles observaram variados graus de acúmulo líquido de alguns nutrientes durante o processo de decomposição da liteira.

Ostertag \& Hobbie (1999) relatam que a manipulação da disponibilidade de nutrientes através da fertilização pode tanto aumentar como diminuir, ou não ter efeito sobre a taxa de decomposição de folhas senescentes. Os autores citam vários trabalhos para cada uma dessas situações e descrevem que o aumento da velocidade do processo de decomposição com o aumento da disponibilidade de nutrientes no solo pode ser devido, principalmente, a um efeito indireto sobre a composição química do tecido foliar que propicia a formação de um material mais facilmente decomponível. Isso seria válido 
também quando se compara "sites" mais ou menos férteis e se observa maior velocidade de decomposiçao nos melhores solos.

Quando se trabalha com aplicação de biossólido em florestas e estudo dos ciclos dos nutrientes, para se entender a dinâmica dos elementos no ecossistema é fundamental considerar o efeito que o resíduo exerce sobre a decomposição da serapilheira e considerar também o modelo de degradação do próprio biossólido. Apesar disso, existem poucos estudos sobre o assunto, principalmente, em condições de campo. Segundo Robinson et al. (2002), que estudaram a decomposição de biossólido e liberação de $\mathrm{N}$, em plantação de Pinus na Austrália, a maioria dos estudos sobre decomposição de biossólidos tém focado esforços sobre as taxas de respiração e evolução de $\mathrm{CO}_{2}$ durante incubação, em laboratório, do material com solo. Esses autores encontraram apenas um trabalho na literatura que relata mudanças temporais na perda de massa de biossólido aplicado sobre a superfície do solo em condições de campo. Quando o biossólido se decompõe ele vai perdendo massa mineral e orgânica e, consequentemente, vários elementos podem ser lavados, lixiviados, volatilizados, imobilizados pelos organismos do solo e/ou extraídos pelas plantas. O componente orgânico, tipicamente, responde por $40 \%$ a $70 \%$ da massa total e pode ser perdido pela liberação de $\mathrm{CO}_{2}$ ou incorporado ao solo através da decomposição, lixiviado como ácidos orgânicos solúveis ou lavado como material particulado. A perda de componentes inorgânicos depende das características químicas e das propriedades particulares de cada elemento.

Segundo Hsieh et al. (1981), que estudaram a decomposição de biossólido em condições controladas, o processo é influenciado pela temperatura (entre 8 e $22{ }^{\circ} \mathrm{C}$, a taxa de mineralização aumentou 1,9 vez com o aumento de $10{ }^{\circ} \mathrm{C}$ ), mas não é afetado pela umidade, entre 0,06 e 0,33 bars, da mistura biossólido-solo.

A dinâmica da decomposição dos resíduos orgânicos, assim como da liberação e absorção dos nutrientes, são etapas essenciais da ciclagem 
biogeoquímica e muito carentes de estudos mais detalhados, ainda mais se tratando da aplicação de biossólido em culturas florestais. 


\section{MATERIAL E MÉTODOS}

\subsection{Descrição da área experimental}

\subsubsection{Situação geográfica}

A Estação Experimental de Ciências Florestais de Itatinga, vinculada ao Departamento de Ciências Florestais da Escola Superior de Agricultura Luiz de Queiroz, localiza-se no município de Itatinga - SP, entre os paralelos $23^{\circ} 02^{\prime}$ $01^{\prime \prime}$ e $23^{\circ} 02^{\prime} 30^{\prime \prime}$ latitude sul e os meridianos $48^{\circ} 37^{\prime} 30^{\prime \prime}$ e $48^{\circ} 38^{\prime} 34^{\prime \prime}$ longitude oeste de Greenwich, com altitude média de $830 \mathrm{~m}$.

\subsubsection{Clima}

O clima local é do tipo mesotérmico úmido, segundo classificação de Köppen, com precipitação média mensal do mês mais seco entre 30 e $60 \mathrm{~mm}$, temperatura mínima anual de $12,8{ }^{\circ} \mathrm{C}$ e média anual de $19,4{ }^{\circ} \mathrm{C}$. A umidade relativa média anual é de $83,3 \%$, e a precipitação média anual é de $1635 \mathrm{~mm}$. O balanço hídrico apresenta um excedente de $762 \mathrm{~mm}$, e déficit de $3 \mathrm{~mm}$ nos meses de julho e agosto, com uma evapotranspiração potencial de $877 \mathrm{~mm}$, e capacidade de armazenamento do solo de $150 \mathrm{~mm}$. 
Pode-se observar a seguir (Figura 1), os valores de precipitação pluviométrica e temperatura, para todos os meses após a aplicação do biossólido, até o término das coletas. Valores anuais podem ser observados na Figura 2. Esses dados são coletados diariamente em uma estação meteorológica localizada próxima à sede da Estação Experimental de Itatinga, que fica distante, aproximadamente, $500 \mathrm{~m}$ da área experimental.

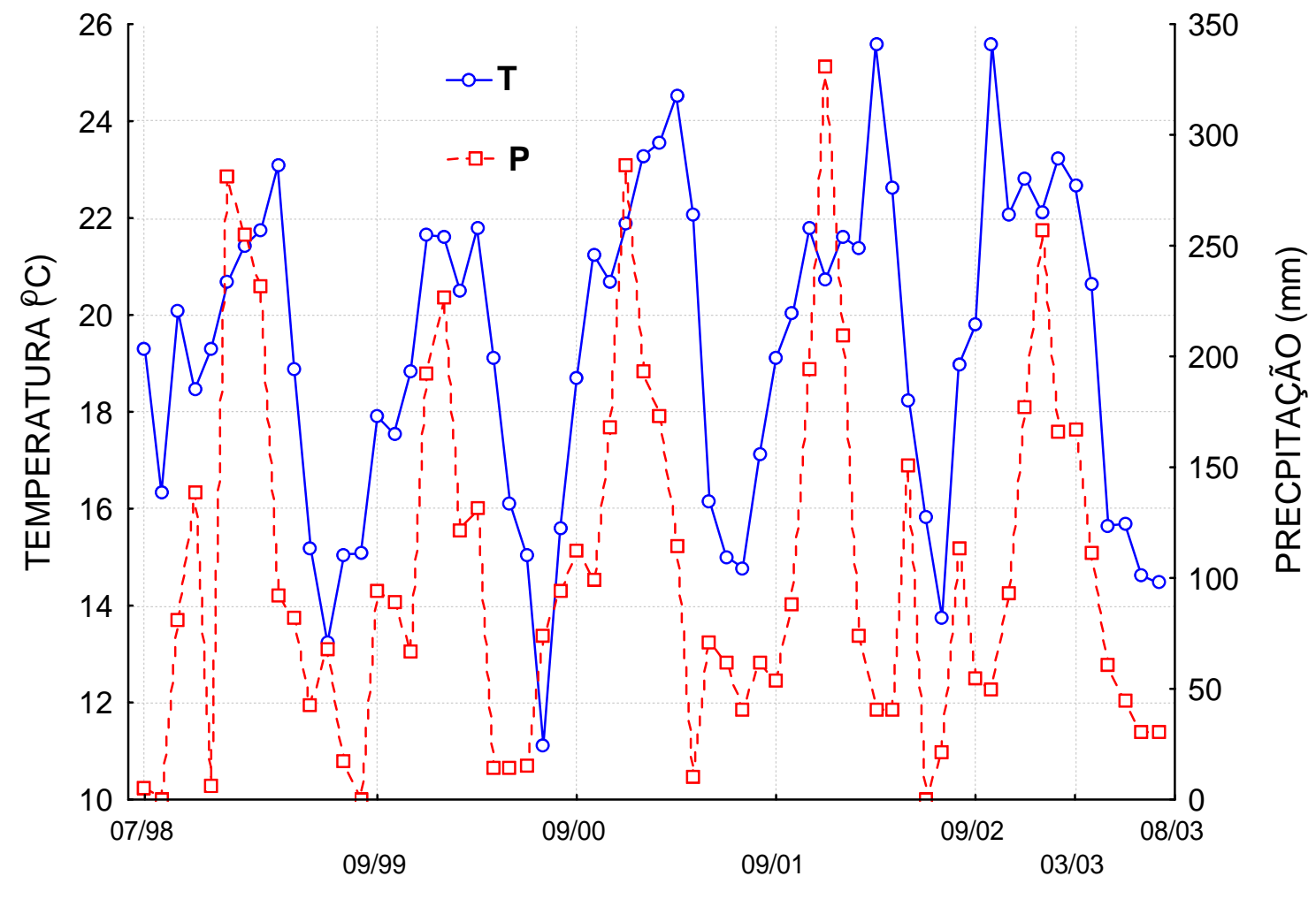

Figura 1- Valores da precipitação mensal $(P)$ e da média mensal da temperatura medida às 9:00h ( $\mathrm{Ta}$ ), para cada mês do período em que o experimento foi conduzido, desde a aplicação do biossólido (07/1998) até o final das coletas (08/2003)

Em 09/99 iniciou-se a coleta de folhedo depositado; em 09/01 iniciou-se a coleta de cascas e galhos depositados; de 06/02 a 06/03 foi conduzido o experimento de decomposição; em 03/03 foi realizada a coleta de amostras de 
solo, de componentes das árvores e serapilheira acumulada, que também foi amostrada em 08/00; em 07/03 foram coletadas amostras de biossólido remanescente.

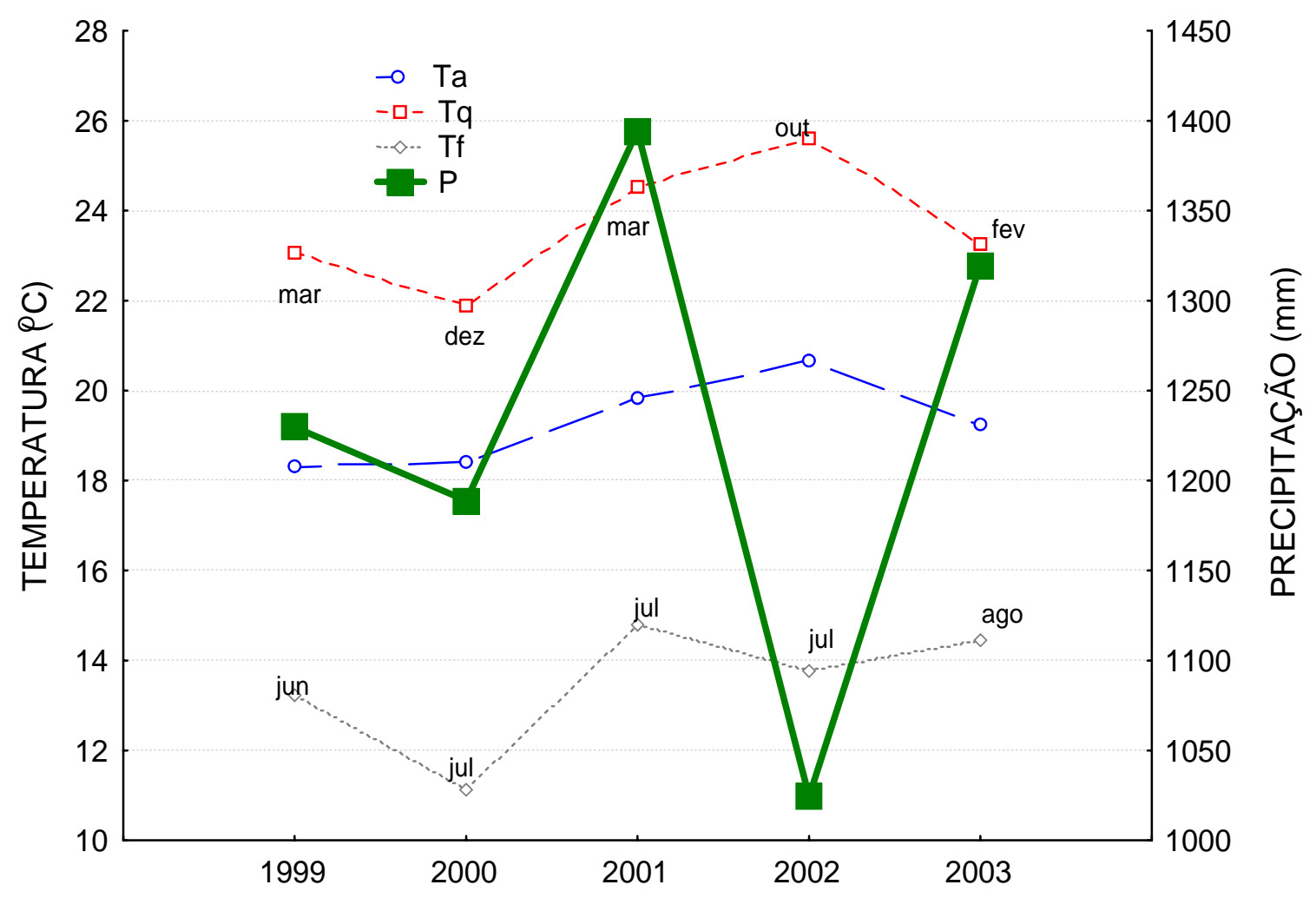

Figura 2- Médias anuais da temperatura medida diariamente às 9:00h (Ta), da temperatura do mês mais quente $(\mathrm{Tq})$ e mais frio ( $\mathrm{Tf}$ ) de cada ano, com os respectivos nomes dos meses, e valores totais da precipitação anual (P)

Observa-se que, de 1999 a 2002, a temperatura média aumentou em, aproximadamente, $2{ }^{\circ} \mathrm{C}$, com aumentos crescentes durante todo o período. $\mathrm{O}$ ano de 2002 foi o ano mais quente e seco, apresentando maiores valores de temperatura média e máxima e menor valor de precipitação anual. Durante os anos de coleta de folhedo e de cascas e galhos depositados pelos eucaliptos (Figura 3), que não coincidiram com os anos civis, foram observados os 
seguintes valores para a precipitação total e para a média da temperatura medida às 9:00h: ano 1 (09/1999 a 08/2000) - $1132 \mathrm{~mm}$ e 18,1 ${ }^{\circ} \mathrm{C}$; ano 2 (09/2000 a 08/2001) - $1225 \mathrm{~mm}$ e 19,7 ${ }^{\circ} \mathrm{C}$; ano 3 (09/2001 a 08/2002) - 1318 $\mathrm{mm}$ e $20,0{ }^{\circ} \mathrm{C}$; ano $4\left(09 / 2002 \mathrm{a} \mathrm{08/003)}\right.$ - $1242 \mathrm{~mm}$ e $19,9{ }^{\circ} \mathrm{C}$.

\subsubsection{Solo e vegetação}

O solo da área experimental é um Latossolo Vermelho-amarelo com textura médio-arenosa, suavemente ondulado e de baixa fertilidade natural. Esse tipo de solo, cuja caracterização pode ser observada na Tabela 2, é um dos mais representativos das áreas onde, hoje, se pratica a silvicultura intensiva do eucalipto no Estado de São Paulo.

Tabela 2. Caracterização química e física do solo da área experimental, realizada antes da implantação do experimento (02/1998), em diversas profundidades $(\mathrm{Pf})$

\begin{tabular}{|c|c|c|c|c|c|c|c|c|c|c|c|c|}
\hline $\begin{array}{l}\text { Pf } \\
(\mathrm{cm})\end{array}$ & $\begin{array}{c}\mathbf{p H} \\
\mathrm{CaCl}_{2}\end{array}$ & $\begin{array}{l}\text { M.O. } \\
\mathrm{g} \mathrm{dm}^{-3}\end{array}$ & $\begin{array}{c}\text { *P } \\
\mathrm{mg} \mathrm{dm}^{-3}\end{array}$ & K & $\mathrm{Ca}$ & $\mathrm{Mg}$ & $\begin{array}{c}\mathbf{H}+\mathbf{A l} \\
\mathrm{mmol}_{\mathrm{c}} \mathrm{dr}\end{array}$ & $\begin{array}{l}\text { Al } \\
m^{-3}---\end{array}$ & SB & $T$ & $\begin{array}{l}\mathbf{V} \\
\%\end{array}$ & $\begin{array}{c}\text { Sat. Al } \\
\%\end{array}$ \\
\hline $0-5$ & 3,4 & 47 & 4 & 0,9 & 1 & 1 & 128 & 24 & 3 & 131 & 2 & 89 \\
\hline $5-10$ & 3,7 & 21 & 5 & 0,2 & 1 & 1 & 68 & 15 & 2 & 70 & 3 & 87 \\
\hline $10-20$ & 3,8 & 17 & 4 & 0,2 & 1 & 1 & 58 & 12 & 2 & 60 & 4 & 84 \\
\hline $20-40$ & 3,9 & 14 & 3 & 0,2 & 2 & 1 & 47 & 8 & 3 & 50 & 6 & 71 \\
\hline $\begin{array}{l}\mathrm{Pf} \\
\mathrm{cm}\end{array}$ & $\mathrm{Cu}$ & $\mathrm{Zn}$ & $\begin{array}{c}\mathrm{Mn} \\
--\mathrm{mg} \mathrm{dm}^{-3}\end{array}$ & $\mathrm{Fe}$ & $S$ & B & Areia & Silte & Argila & D & $\mathrm{g} \mathrm{cr}$ & D R \\
\hline $0-5$ & 1,0 & 1,4 & 1,8 & 87 & 5 & 0,07 & 88 & 4 & 8 & 1,2 & & 2,30 \\
\hline $5-10$ & 1,4 & 0,6 & 0,8 & 76 & 7 & 0,06 & 85 & 5 & 10 & 1,2 & & 2,30 \\
\hline $10-20$ & 1,0 & 0,8 & 0,4 & 68 & 10 & 0,07 & 85 & 5 & 10 & 1,2 & & 2,30 \\
\hline $20-40$ & 1,2 & 0,4 & 0,4 & 55 & 13 & 0,06 & 85 & 5 & 10 & 1,3 & & 2,33 \\
\hline
\end{tabular}


Observam-se valores extremamente baixos de $\mathrm{P}$ disponível, de $\mathrm{K}$, $\mathrm{Ca}$ e $\mathrm{Mg}$ trocáveis, além de elevada saturação por Al, baixo pH e baixos teores das frações de textura mais fina. Além do fato desse tipo de solo ser naturalmente muito intemperizado e pouco fértil, outro fato que pode ter agravado a baixa disponibilidade de nutrientes é que na área foram conduzidas, por aproximadamente cinqüenta anos, seguidas rotações de Eucalyptus saligna sem qualquer reposição dos nutrientes via adubação.

A vegetação natural da região é o cerrado, sendo que a maior parte da estação era, primitivamente, ocupada por cerrado sensu stricto. Atualmente, existem na E. E. de Itatinga algumas manchas remanescentes desse tipo de vegetação, mas predominam as culturas florestais de eucaliptos e pinheiros.

\subsubsection{Plantio e tratos silviculturais}

A área do talhão experimental era ocupada por um povoamento de Eucalyptus saligna com idade aproximada de cinqüenta anos e submetido a vários ciclos de corte sem qualquer adubação. Para implantar este experimento, a madeira foi colhida e a área reformada com mudas originadas de sementes de Eucalyptus grandis, em março de 1998, no sistema de cultivo mínimo. Um mês após o plantio foi realizada capina química à base de glifosato, e treze meses após foi realizada roçada manual. O controle de formigas cortadeiras foi realizado com iscas formicidas à base de sulfluramida, pré e pós-implantação. Um ano após o plantio foi aplicado fungicida Bayfidan $\left(2 \mathrm{~kg} \mathrm{ha}^{-1}\right)$ para controle de ferrugem.

\subsection{Caracterização e aplicação do biossólido}

O material utilizado no experimento foi proveniente da estação de tratamento de esgoto (ETE) de Barueri, região metropolitana de São Paulo. A SABESP foi responsável pela caracterização físico-química e manutenção da 
qualidade do lodo enviado, dentro do estabelecido pela norma norte-americana 40 CFR Part 503 elaborada pela agência de proteção ambiental dos Estados Unidos (USEPA, 1984) e pela norma do Estado de São Paulo (CETESB, 1999). O biossólido aplicado na área experimental foi produzido após tratamento biológico dos esgotos (digestão aeróbia utilizando ar difuso durante a fase de decantação e digestão anaeróbia dos lodos primários e secundários) seguido de condicionamento químico $\left(\mathrm{Ca}(\mathrm{OH})_{2}\right.$ e $\left.\mathrm{FeCl}_{3}\right)$ e desidratação na fase final. Em setembro de 2000 a SABESP deixou de utilizar o condicionamento químico com cal e cloreto férrico e passou a utilizar um polímero catiônico.

O material utilizado possuía densidade de coliformes fecais inferior a $2 \mathrm{x}$ $10^{-6} \mathrm{NMP} \mathrm{g} \mathrm{ST}^{-1}$ (Número Mais Provável por grama de Sólidos Totais), sendo caracterizado como biossólido tipo B (CETESB, 1999); já que o processo de estabilização com cal é aceito pelo órgão controlador como eficiente na redução de patógenos e a densidade dos organismos indicadores ficou abaixo do limite permitido. A caracterização química do biossólido é apresentada a seguir (Tabela 3).

Tabela 3. Caracterização química do biossólido aplicado na área de estudo. Valores totais expressos em base seca

\begin{tabular}{|c|c|c|c|c|c|c|c|}
\hline $\mathbf{N}$ & $\mathbf{P}$ & $\mathrm{K}$ & $\begin{array}{l}\text { C org } \\
-g_{\text {kg }}^{-1}\end{array}$ & $\mathbf{C a}$ & Mg & $\mathrm{SO}_{4}^{-}$ & $\begin{array}{c}\mathbf{p H} \\
\left(\mathrm{CaCl}_{2}\right)\end{array}$ \\
\hline 19 & 9 & 2 & 172 & 86 & 4 & 7 & 10,6 \\
\hline $\mathrm{Fe}$ & $\mathrm{Cu}$ & $M n$ & $\mathrm{Zn}$ & Cd & $\mathrm{Cr}$ & $\mathrm{Ni}$ & $\mathrm{Pb}$ \\
\hline 55056 & 900 & 258 & 1632 & - & 258 & 222 & 82 \\
\hline
\end{tabular}

-abaixo do limite de detecção

Ao analisar a composição do biossólido utilizado, verifica-se que seus atributos $(\mathrm{pH}$, relação $\mathrm{C} / \mathrm{N}$ e macronutrientes) são semelhantes aos valores médios apresentados em Andrade (2004). Esse autor, baseando-se na revisão de oito 
trabalhos da literatura, apresenta a composição média de parâmetros de biossólidos utilizados em experimentos no Estado de São Paulo, conforme pode ser observado na Tabela 4.

Tabela 4. Valores médios e desvio padrão de alguns parâmetros químicos de interesse agronômico, calculados a partir dos resultados de análises químicas de biossólidos utilizados em experimentos no Estado de São Paulo. Valores expressos em base seca (Andrade, 2004)

\begin{tabular}{ccc}
\hline Parâmetro & Unidade & Média \pm Desvio Padrão \\
\hline pH & $--.------1 \pm 2,3$ \\
C-orgânico & $\mathrm{g} \mathrm{kg}^{-1}$ & $9,1 \pm 0 \pm 70$ \\
N-total & $\mathrm{g} \mathrm{kg}^{-1}$ & $21,5 \pm 7,0$ \\
C/N & --------- & $9 \pm 3$ \\
P-total & $\mathrm{g} \mathrm{kg}^{-1}$ & $10,8 \pm 6,1$ \\
K-total & $\mathrm{g} \mathrm{kg}^{-1}$ & $1,4 \pm 0,5$ \\
Ca-total & $\mathrm{g} \mathrm{kg}^{-1}$ & $102,8 \pm 75,5$ \\
Mg-total & $\mathrm{g} \mathrm{kg}^{-1}$ & $4,0 \pm 2,3$ \\
S-total & $\mathrm{g} \mathrm{kg}^{-1}$ & $10,1 \pm 4,4$ \\
\hline
\end{tabular}

Para distribuir o biossólido que apresentava por volta de $60 \%$ de umidade (base úmida), em julho de 1998, foi utilizada uma carreta com capacidade de $3 \mathrm{~m}^{3}$ puxada por um trator. O biossólido foi aplicado a lanço, em cobertura, entre as linhas de plantio (faixa de $2 \mathrm{~m}$ ), deixando, aproximadamente, meio metro de distância das mudas.

\subsection{Delineamento experimental e tratamentos}

O experimento foi implantado em blocos casualizados definidos em função da declividade existente no sentido do bloco 1 para o bloco 4, que fica situado na parte mais baixa. Foram aplicados nove tratamentos com quatro 
repetições, totalizando trinta e seis parcelas. Cada parcela possui $600 \mathrm{~m}^{2}$ (30 m x $20 \mathrm{~m}$ ) e foi constituída por dez linhas de $20 \mathrm{~m}$ de comprimento cada. Na linha as plantas foram espaçadas de $2 \mathrm{~m}$ e nas entrelinhas em $3 \mathrm{~m}$, totalizando cem plantas por parcela. A posição das parcelas dentro de cada bloco foi definida por sorteio. A área útil da parcela considerou as trinta e seis plantas centrais, descontando-se a bordadura dupla, ou seja, uma área efetiva de amostragem de $216 \mathrm{~m}^{2}$. Na área experimental foram aplicados nove tratamentos, variando doses de biossólido e complementação com fertilizantes minerais. Nesse trabalho, foram avaliados apenas cinco tratamentos:

1) testemunha absoluta, sem adubação e sem aplicação de biossólido (tt);

2) adubação mineral (ad);

3) $10 \mathrm{Mg} \mathrm{ha}^{-1}$ de biossólido complementado com K e P no plantio (10+KP);

4) $20 \mathrm{Mg} \mathrm{ha}^{-1}$ de biossólido complementado com $\mathrm{K}(20+\mathrm{K}) \mathrm{e}$

5) $40 \mathrm{Mg} \mathrm{ha}^{-1}$ de biossólido complementado com K $(\mathbf{4 0}+\mathrm{K})$.

As doses de biossólido foram calculadas em base seca. No entanto, o material foi aplicado úmido. Assim, por exemplo, uma dose de $10 \mathrm{Mg} \mathrm{ha}^{-1}$ (base seca), corresponde a $25 \mathrm{Mg} \mathrm{ha}^{-1}$ de material com 60\% de umidade. A dose máxima de biossólido aplicada, $40 \mathrm{Mg} \mathrm{ha}^{-1}$, foi definida em função do seu elevado teor de $\mathrm{Ca}$, resultante do processo de tratamento do esgoto, que poderia causar desequilíbrios nutricionais. Outros fatores, como teor e taxa de mineralização do $\mathrm{N}$ e teores de metais pesados, também foram considerados na determinação das doses aplicadas.

A adubação mineral no tratamento "ad", conforme descrito por Vaz (2000), que trabalhou na mesma área experimental, foi realizada da seguinte maneira: $1,5 \mathrm{Mg} \mathrm{ha}^{-1}$ de calcário dolomítico (a lanço em área total), $110 \mathrm{~kg} \mathrm{ha}^{-1}$ de 0-45-0 (sulco de plantio), $150 \mathrm{~kg} \mathrm{ha}^{-1}$ de 10-20-10 (sulco de plantio), $80 \mathrm{~kg}$ $\mathrm{ha}^{-1}$ de 20-0-20 (45 dias pós-plantio aplicado em meia lua ao redor da muda), $180 \mathrm{~kg} \mathrm{ha}^{-1}$ de 16-0-32 + 0,3\% B + 0,5\% de Zn (6 meses pós-plantio aplicado numa faixa de $40 \mathrm{~cm}$ na entrelinha de plantio) e $240 \mathrm{~kg} \mathrm{ha}^{-1}$ de $16-0-32+0,3 \%$ 
B + 0,5\% de Zn (12 meses pós-plantio aplicado numa faixa de $40 \mathrm{~cm}$ na entrelinha de plantio). Essa adubação propiciou a entrada das seguintes quantidades dos nutrientes que estão sendo analisados nesta tese com a aplicação dos fertilizantes: $98 \mathrm{~kg} \mathrm{ha}^{-1}$ de $\mathrm{N}, 35 \mathrm{~kg} \mathrm{ha}^{-1}$ de $\mathrm{P}, 357 \mathrm{~kg} \mathrm{ha}^{-1}$ de Ca, $163 \mathrm{~kg} \mathrm{ha}^{-1}$ de Mg, $16 \mathrm{~kg} \mathrm{ha}^{-1}$ de S, $0 \mathrm{~kg} \mathrm{ha}^{-1}$ de Mn e 2,1 $\mathrm{kg} \mathrm{ha}^{-1}$ de Zn.

A complementação com $\mathrm{K}$ mineral $\left(\mathrm{KCl}, 60 \%\right.$ de $\left.\mathrm{K}_{2} \mathrm{O}\right)$ foi necessária em todos os tratamentos onde foi aplicado biossólido, porque o teor desse elemento no resíduo é baixo, assim como no solo da área experimental. $\mathrm{O} \mathrm{KCl}$ foi colocado em cada tratamento, de acordo com a dose de biossólido, até igualar a quantidade de $\mathrm{K}$ colocada no tratamento com adubação mineral "ad" (137 kg ha-1). Desse modo, com o aumento da dose de biossólido foi adicionado menos $\mathrm{K}$ mineral. Para a suplementação de $\mathrm{P}$ nas parcelas do tratamento "10+KP" foi utilizada a formulação 0-45-0, aplicando-se $80 \mathrm{~kg} \mathrm{ha}^{-1}$ no sulco do plantio.

\subsection{Coleta e composição das amostras}

O sistema de amostragem seguiu delineamento sistematizado durante a realização das coletas das amostras, que foram sempre realizadas dentro da área útil das parcelas.

\subsubsection{Serapilheira depositada e acumulada}

A serapilheira depositada se refere ao material vegetal senescente que caiu das árvores de eucalipto. Foram analisadas as folhas (folhedo), as cascas e os galhos. A serapilheira acumulada se refere à miscelânea de material vegetal em decomposição, também denominada de manta florestal ou liteira.

Para coletar o folhedo foram utilizadas bandejas constituídas por bordas de madeira que prendem uma tela de nylon (malha de $2 \mathrm{~mm}$ ) e são fixadas sobre quatro estacas. A tela é disposta em forma de bolsa côncava e fica 
suspensa, aproximadamente, $50 \mathrm{~cm}$ acima do solo. As bordas laterais dos coletores possuem $8 \mathrm{~cm}$ de altura e a área interna do coletor é de 0,3249 m² (57 $x 57 \mathrm{~cm}$ ). Os coletores foram dispostos no campo entre as linhas de plantio. No centro da área útil de cada parcela, foram colocados três coletores em diagonal, totalizando doze repetições para cada tratamento. O folhedo foi coletado mensalmente, a partir de setembro de 1999, catorze meses após a aplicação do biossólido, quando as árvores possuíam dezoito meses de idade e se observou o fechamento das copas e o começo de uma deposição de folhas mais efetiva. O material dos três coletores de cada parcela, somados dois meses consecutivos, constituiu uma amostra composta para análise química dos nutrientes.

A coleta de galhos e cascas foi realizada em parcelas de $16 \mathrm{~m}^{2}(4 \times 4 \mathrm{~m})$, demarcadas rente ao solo envolvendo quatro árvores. Este material foi coletado a cada três meses, desde setembro de 2001, quando as árvores possuíam idade de três anos e meio. Nessa época foi realizada desrama de todas as árvores, até $2 \mathrm{~m}$ de altura, para homogeneizar as condições em todas as parcelas e facilitar a coleta próximo aos troncos. O material coletado em cada parcela durante duas coletas consecutivas constituiu uma amostra composta para análise química.

A serapilheira acumulada sobre o solo (manta florestal) foi determinada em fevereiro de 2000 e em março de 2003, utilizando moldura de 0,25 $\mathrm{m}^{2}(0,5 \mathrm{x}$ 0,5 m), com o auxílio de um facão. Foram coletadas, nas entre-linhas de plantio, em locais próximos aos coletores de folhedo, três amostras por parcela, totalizando doze repetições por tratamento para a variável fitomassa. As três amostras de cada parcela foram processadas juntas para compor uma amostra para realizar a determinação química dos nutrientes. 


\subsubsection{Decomposição do folhedo}

A decomposição do folhedo foi avaliada através do método das bolsas de decomposição, modificado por Anderson e Ingram (1993) e também utilizado por Bubb et al. (1998). Essa técnica difere da original, pois são usados cilindros vazados para delimitar o material, que é colocado em contato direto com o solo, permitindo o acesso da fauna e flora do solo, reconhecidamente importantes participantes do processo de decomposição. Além disso, há menor influência do recipiente sobre o microclima em que estão as amostras, já que os cilindros não entram em contato direto com as amostras, como ocorre com as bolsas de decomposição. Em cada parcela foram colocados, no início do mês de junho de 2002, cinco cilindros, deixando uma distância de $50 \mathrm{~cm}$ entre eles. Os cilindros foram confeccionados com tubos de PVC de $20 \mathrm{~cm}$ de diâmetro por $15 \mathrm{~cm}$ de altura. A borda inferior do cilindro foi enterrada cerca de $5 \mathrm{~cm}$ no solo e foram colocados no interior de cada um $5 \mathrm{~g}$ de folhedo seco, coletado durante os meses de janeiro e fevereiro de 2002. Nos cinco cilindros de cada parcela foi colocado folhedo coletado na própria parcela, mantendo assim a influência dos tratamentos sobre a qualidade inicial do material. Logo após, cada cilindro foi recoberto com uma tela tipo sombrite para evitar entrada de novo material vegetal proveniente do dossel. Durante o período de um ano todos os cilindros foram retirados, sendo coletado o conteúdo de um cilindro em cada parcela aos três, seis, oito, dez e doze meses após a instalação. O material constituído por folhas em diferentes graus de decomposição, foi cuidadosamente limpo, seco a $65{ }^{\circ} \mathrm{C}$ até peso constante e teve seu peso seco final determinado. O material das quatro parcelas de cada tratamento, retirado a cada coleta, constituiu uma amostra composta para análise dos nutrientes e da qualidade da matéria orgânica. 


\subsubsection{Solo e biossólido remanescente}

Em março de 2003, cinco anos após o plantio dos eucaliptos, foram coletadas cinco amostras de terra nas entrelinhas de cada parcela, nas profundidades de 0-10, 10-20 e 20-30 cm, para compor uma amostra por profundidade por parcela. Foram coletadas duas amostras indeformadas para análise da densidade, nas mesmas profundidades anteriores, dentro da área útil da parcela, utilizando anéis de $65 \mathrm{~cm}^{3}$ (2,5 cm de diâmetro e 3,3 cm de altura).

As amostras de biossólido remanescente na área foram coletadas cinco anos após a aplicação do resíduo, em julho de 2003. A coleta foi realizada seguindo a diagonal da área útil das parcelas, sendo coletadas três amostras em cada uma, totalizando doze repetições por tratamento. Cada amostra foi coletada em área de 0,25 $\mathrm{m}^{2}(0,5 \times 0,5 \mathrm{~m})$, com o auxílio de um gabarito, de uma pequena pá e de duas peneiras (malhas de $2 \mathrm{~mm}$ e $1 \mathrm{~mm}$ ), separando o biossólido em duas frações (a: $>2 \mathrm{~mm}$; b: $>1$ e $\leq 2 \mathrm{~mm}$ ). Antes da coleta, a área foi limpa manualmente, retirando-se, cuidadosamente, a serapilheira e a vegetação de sub-bosque que existiam no local. Após o peneiramento, a fração $>2 \mathrm{~mm}$ ficou constituída praticamente por biossólido puro. A fração mais fina ficou "contaminada", principalmente por uma serapilheira bem fina que estava sendo incorporada ao solo e também, inevitavelmente, por um pouco de terra.

\subsubsection{Componentes das árvores abatidas (lenho, casca, folha e galho)}

Em março de 2003, quando as árvores completaram cinco anos de idade, foram abatidas duas árvores por parcela para determinar a fitomassa e a mineralomassa de cada componente. Para determinar quais árvores seriam abatidas, foi realizado um inventário de todas as árvores do experimento e as trinta e seis árvores úteis de cada parcela foram distribuídas em classes de DAP de $2 \mathrm{~cm}$ de diâmetro, sendo escolhida uma árvore com o diâmetro igual ao do centro da classe dominante (ou as duas se essa classe representava mais 
de 3/4 das árvores) e outra árvore que representava a média dos centros das classes com mais de $1 / 4$ das árvores. Como a parcela é a unidade fundamental do delineamento em blocos ao acaso e seria exigido um esforço muito intenso para abater árvores em várias classes em cada parcela, não foi realizada a tradicional separação em classes e a colheita de uma árvore por classe. Como em várias parcelas a distribuição dos diâmetros não seguiu a curva normal, não foram escolhidas as árvores médias das parcelas, mas sim as que representavam as classes com maior freqüência. As quarenta árvores abatidas (oito por tratamento) no experimento, cobriram a grande variação existente no desenvolvimento dos eucaliptos em função dos diferentes tratamentos.

Para determinação da fitomassa do lenho e casca, foi realizada cubagem rigorosa das árvores abatidas, calculando-se os volumes com e sem casca, e a densidade básica (método da balança hidrostática) desses componentes. Foram coletados discos com casca da base da árvore e a 25\%, 50\%, 75\% e $100 \%$ da altura comercial, além de mais um disco na altura do DAP. Esses discos, que tinham aproximadamente $2 \mathrm{~cm}$ de espessura, foram levados ao laboratório, medidos os diâmetros com e sem casca para calcular o volume pela fórmula de Smalian, e logo após foi retirada uma cunha de cada disco. As cunhas dos discos de cada árvore foram processadas juntas para se obter uma amostra representativa de todo o comprimento do lenho. Após processamento foram juntadas quantidades equivalentes das duas árvores de cada parcela para compor uma amostra de lenho por parcela para análise química. As cascas dos discos das árvores também foram submetidas ao mesmo procedimento anterior para compor uma amostra de casca por parcela.

Todas as folhas e os galhos de cada árvore foram separados no campo e tiveram o peso fresco total determinado utilizando balança de $10 \mathrm{~kg}$ com precisão de $50 \mathrm{~g}$. Foram retiradas amostras que também foram pesadas (balança de $1 \mathrm{~kg}$ com precisão de $5 \mathrm{~g}$ ), acondicionadas e levadas ao laboratório para determinação do peso seco e realização das análises químicas. 
A mineralomassa de cada componente das árvores foi calculada multiplicando-se a fitomassa, estimada por equações alométricas aplicadas em todas as árvores da área útil de cada parcela, pelo respectivo teor de cada nutriente analisado nas amostras da parcela.

\subsection{Determinações analíticas}

Foi observado durante o desenvolvimento de trabalhos anteriores (Guedes, 2000; Vaz \& Gonçalves, 2002) que os nutrientes N, P, Ca, Mg, S, Mn e Zn foram os mais influenciados pela aplicação de biossólido. Em função disto, neste trabalho, foram analisados apenas esses elementos.

\subsubsection{Material vegetal}

As análises químicas de material vegetal (folhedo, cascas e galhos depositados, serapilheira acumulada, componentes das árvores, folhas em diferentes graus de decomposição) foram realizadas após o material ser seco a $65{ }^{\circ} \mathrm{C}$ em estufas de ventilação forçada até peso constante, e trituração em moinho tipo Wiley (peneira de 20 mesh $=0,8 \mathrm{~mm}$ ). As determinações dos teores dos nutrientes foram realizadas no Laboratório de Ecologia Aplicada do Departamento de Ciências Florestais, da Escola Superior de Agricultura "Luiz de Queiroz". O N foi determinado por titulação após digestão em microKjeldhal. Os demais elementos foram determinados após digestão nítricoperclórica (3:1): o P por colorimetria; o S por turbidimetria; o Ca, o Mg, o Mn e o Zn por espectrofotometria de absorção atômica, conforme descrito em Malavolta et al. (1997).

As determinações dos teores de lignina (LIG), extrativos totais (ET), fenóis, carbono e cinzas foram realizadas no Laboratório de Química da Madeira do Departamento de Ciências Florestais, após ataques químicos com diferentes reagentes e determinações por gravimetria segundo as normas da 
TAPPI (1999). Os teores de holocelulose foram calculados pela diferença [100 $(E T+$ LIG)]. Segundo Ryan et al. (1990) e Sanger et al. (1996), os procedimentos analíticos para a determinação das concentrações de compostos orgânicos como lignina, hemicelulose, celulose, carboidratos, lipídeos e proteínas em amostras vegetais são denominadas de "análises aproximadas", e tiveram sua origem na avaliação da digestibilidade de forrageiras. As análises aproximadas definem frações orgânicas operacionais baseadas na suscetibilidade à hidrólise ou extração, usando no procedimento soluções polares, não polares, ácidas e/ou alcalinas, com ou sem fonte externa de calor. No entanto, os ataques químicos ao material orgânico analisado podem provocar alterações na natureza inicial dos componentes. Atualmente, com o refinamento de técnicas analíticas espectroscópicas, como a Ressonância magnética Nuclear (RMN), há possibilidade de se identificar e quantificar diferentes grupos funcionais da matéria orgânica, assim como os graus de aromaticidade e alifaticidade (Ceretta et al., 1999). A vantagem principal dessas técnicas é a possibilidade de quantificar diversos compostos orgânicos sem a destruição da amostra por agentes químicos, realizando apenas uma moagem para redução das partículas ao tamanho adequado (Preston et al., 1997). A estrutura do C e os componentes da matéria orgânica foram analisados através de RMN em laboratório da Embrapa Instrumentação Agropecuária de São Carlos, SP. Foi utilizado um espectrômetro Varian Unity Inova 400, com rotor Doty tipo "SuperSonic" (rotação: $7 \mathrm{kHz}$ ) e padrão de referência: Hexametilbenzeno $(\mathrm{HMB})=17,2$ ppm.

\subsubsection{Terra}

As análises da terra coletada foram realizadas após secagem a $40{ }^{\circ} \mathrm{C}$ em estufas de ventilação forçada até peso constante e peneiramento em malha de $2 \mathrm{~mm}$ (9 mesh). As determinações dos teores totais dos nutrientes foram realizadas após digestão em mistura de ácido nítrico e clorídrico (1:3) em forno 
de microondas. O C e $\mathrm{N}$ foram determinados em equipamento auto-analisador Leco, P por colorimetria, Ca, Mg, Mn e Zn por espectrometria de absorção atômica. Não foi possível realizar a análise do $S$ total na terra devido a problemas metodológicos.

Foram também determinados teores trocáveis e disponíveis de nutrientes, conforme Raij et al. (2001).

\subsubsection{Biossólido}

As análises do biossólido foram realizadas após secagem a $40{ }^{\circ} \mathrm{C}$ em estufas de ventilação forçada até peso constante e moagem do material em cadinho com pistilo até virar um pó bem fino. As determinações dos teores totais dos nutrientes foram realizadas no Laboratório de Química Ambiental do Departamento de Química Ambiental da ESALQ, após digestão via seca para $\mathrm{P}, \mathrm{Ca}, \mathrm{Mg}, \mathrm{Mn}$ e Zn, digestão Kjeldhal para $\mathrm{N}$ e digestão via seca para o S após tratamento com $\mathrm{NaOH}$ para evitar perdas por volatilização.

\subsection{Análise dos dados}

Foi realizada uma análise exploratória dos dados, para verificar as pressuposições necessárias a cada análise, a necessidade de transformação dos dados ou de realização de análises não paramétricas.

As variáveis respostas referentes à deposição de serapilheira e nutrientes, ao conteúdo de nutrientes nos componentes das árvores, assim como a fitomassa, foram analisadas através da Análise de Variância. As comparações entre as médias foram realizadas através dos Intervalos de Confiança construídos com 95\% de certeza e pelo teste de Tukey para avaliar as diferenças em níveis específicos de "p value". Quando a variável resposta foi medida várias vezes ao longo do tempo, foi realizada análise de medidas 
repetidas para dados coletados em várias épocas sobre a mesma unidade amostral, segundo Crowder e Hand (1990).

O efeito dos tratamentos sobre a quantidade de folhedo remanescente ao longo do processo de decomposição foi verificado através de análise de covariância. A variável categórica "tratamento" foi considerada o fator principal, o tempo de decomposição a covariável e a fitomassa de folhedo remanescente a variável resposta. Foram ajustadas equações e calculadas as taxas de decomposição segundo o modelo exponencial negativo de perda de massa e nutrientes ao longo do tempo, proposto por Olson (1963). Apesar de não ser o melhor modelo para estimar a taxa de decomposição, o modelo exponencial negativo simples é o mais freqüentemente utilizado, pois uma única constante caracteriza a perda de massa, o que facilita a comparação (Louzada et al., 1997).

Para estimativa da fitomassa das árvores foram ajustadas equações alométricas usando um modelo exponencial, com regressão pela origem, em método iterativo de Gauss-Newton que minimiza a função de perda. As funções de variação para a fitomassa seca de cada componente foram escolhidas após testar, em uma matriz de correlações, várias funções utilizadas em estudos semelhantes e verificar o ajuste e a distribuição dos resíduos das equações que representavam as melhores correlações. As funções selecionadas e utilizadas neste estudo foram:

- variação da fitomassa seca do lenho em função da variável combinada $\log \left(\mathrm{DAP}^{2}\right.$ x HT) (Santana et al., 1999);

- variação da fitomassa seca de cascas em função do DAP² (Silva, 1996);

- variação do $\log _{10}$ da fitomassa seca de galhos ou folhas em função do $\log _{10}$ DAP ${ }^{2}$ (Hart, 2003);

sendo fitomassa seca em quilos por árvore, DAP (diâmetro à altura do peito) em centímetros e HT (altura total) em metros. 
O modelo global $(n=40)$ de cada componente foi testado contra modelos parciais ajustados para cada tratamento $(n=8)$, para verificar a hipótese nula que o modelo global tem a mesma precisão que os modelos por tratamento, utilizando a seguinte estatística baseada no teste $\mathrm{F}$ :

$F C=\left(S Q R g-\sum S Q R t_{i}\right) /\left(G L g-\sum G_{t}\right) /\left(\sum S Q R t_{i} / \sum G L t_{i}\right)$, onde:

SQRg = soma de quadrados dos resíduos do modelo global;

$\mathrm{SQRt}_{\mathrm{i}}=$ soma de quadrados dos resíduos do modelo parcial para cada tratamento;

GLg = graus de liberdade do modelo global;

$\mathrm{GLt}_{\mathrm{i}}=$ graus de liberdade do modelo parcial para cada tratamento.

Como foi aceita a hipótese nula para os modelos de todos os componentes, utilizou-se os modelos globais, já que apresentam a mesma precisão dos modelos parciais por tratamento e maior grau de liberdade para os resíduos, além de maior escopo de ação.

As equações ajustadas utilizando os modelos globais para todas as árvores abatidas $(\mathrm{n}=40)$ foram:

$\rightarrow$ lenho $=0,000000702 \times\left[\log \left(D^{2} P^{2} H T\right)\right]^{8,5849} ; r^{2}=0,94 ; p<0,001 ;$

$\rightarrow$ cascas $=0,008033 \times\left(D^{2} P^{2}\right)^{1,27102} ; r^{2}=0,86 ; p<0,001 ;$

$\rightarrow \log _{10}$ galhos $=0,004966 \times\left(\log _{10} D_{A P}^{2}\right)^{5,8579} ; r^{2}=0,61 ; p<0,001 ;$

$\rightarrow \log _{10}$ folhas $=0,005521 \times\left(\log _{10} D P^{2}\right)^{5,55305} ; r^{2}=0,66 ; p<0,001 ;$

As equações ajustadas foram aplicadas sobre as trinta e seis árvores da área útil de cada parcela. A seguir foi somada a fitomassa por parcela e convertida em fitomassa por hectare. Também foi realizado o mesmo procedimento em relação ao volume.

A equação ajustada através da cubagem rigorosa das árvores, aos cinco anos de idade, foi utilizada para calcular os volumes e ajustar a curva de crescimento, utilizando os dados dos inventários ao longo da rotação. A equação utilizada foi: 
Volume do tronco com casca $=0,000017 \times \mathrm{DAP}^{1,9117} \times \mathrm{HT}^{1,3065} ; \mathrm{R}^{2}=0,98$, $\mathrm{p}<0,001, \mathrm{SQR}=0,0021$.

Também foram realizados testes de correlação, assim como foram calculados índices utilizando a proporção entre as variáveis. O Coeficiente de Utilização Aparente, calculado conforme (Labrecque et al., 1995), indica as proporções dos nutrientes contidos nos fertilizantes e biossólido que foram imobilizados nos eucaliptos.

Coeficiente de Utilização Aparente: CUA = 100 (CEt - CEc) / CEdb, onde:

CEt é o conteúdo do elemento nas árvores em cada tratamento;

CEc é o conteúdo do elemento nas árvores do tratamento controle;

CEdb é o conteúdo do elemento na dose de biossólido aplicada em cada tratamento. 


\section{RESULTADOS E DISCUSSÃO}

\subsection{Deposição de serapilheira e retorno de nutrientes ao solo}

A Figura 3 mostra a quantidade total de folhedo produzido, durante quatro anos de coleta, pelos eucaliptos de cada tratamento, desde setembro de 1999, quando as árvores possuíam dezoito meses de idade e por ocasião do fechamento das copas. As diferenças entre os tratamentos foram estatisticamente significativas $(F=17,833$ e $p<0,001)$. Observando os intervalos de confiança, pode-se afirmar com 95\% de certeza, que o tratamento testemunha (tt) é diferente de todos os outros, assim como o tratamento "40+K", e que os tratamentos "ad", "10+KP" e "20+K" não apresentam diferenças significativas ao nível de $5 \%$ de probabilidade. Essas diferenças são confirmadas pelo teste de Tukey abaixo de $1 \%$ de probabilidade, menos a diferença entre o tratamento "40+K" e "10+KP", que só é significativa até uma probabilidade $\mathrm{p}=0,031$. 


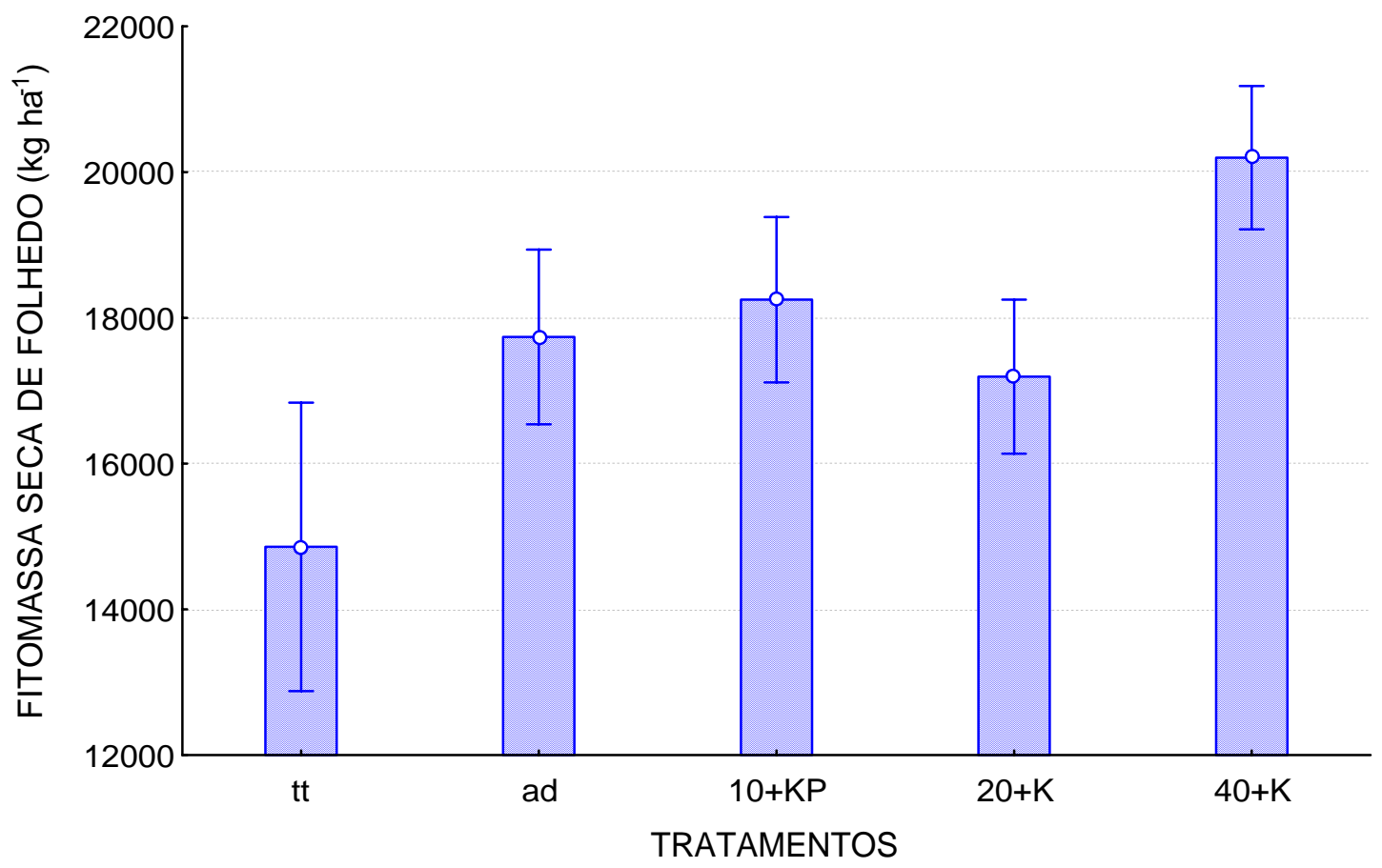

Figura 3- Valores médios do total de fitomassa seca de folhedo depositado pelos eucaliptos durante os quatro anos de coleta, desde setembro de 1999 a agosto de 2003, nos diferentes tratamentos: tt (testemunha), ad (adubação mineral), 10+KP (10 Mg ha ${ }^{-1}$ de biossólido complementadas com K e P mineral), $20+\mathrm{K}$ ( $20 \mathrm{Mg}^{-1}{ }^{-1}$ de biossólido mais $\mathrm{K}$ mineral), $40+\mathrm{K}\left(40 \mathrm{Mg}^{-1}{ }^{-1}\right.$ de biossólido mais $\mathrm{K}$ mineral). A variação em torno da média $(n=12)$ é representada pelo intervalo de confiança construído com $95 \%$ de certeza

Pode-se observar que a aplicação de biossólido altera os padrões de deposição de folhedo e, conseqüentemente, a ciclagem dos nutrientes. Durante quatro anos de desenvolvimento, as árvores que receberam a maior dose de biossólido produziram e devolveram ao solo $20 \mathrm{t}$ de folhedo, $5340 \mathrm{~kg}$ de folhas senescentes a mais do que as árvores testemunhas e $2422 \mathrm{~kg}$ a mais do que os eucaliptos que receberam adubação mineral completa. Essa é uma quantidade substancial de matéria orgânica e nutrientes que são reciclados dentro do ecossistema, contribuindo para a sua sustentabilidade. $O$ ecossistema florestal tem a capacidade de alimentar, continuamente, o solo com matéria orgânica, através da fixação de elevadas quantidades de $\mathrm{CO}_{2}$ 
atmosférico em sua biomassa, que vai se depositando na área. A aplicação de biossólido, no caso das plantações de eucalipto, potencializa essa capacidade, ampliando ainda mais a produção de folhas pelas árvores e a conseqüente transferência de material orgânico para o solo quando elas senescem e caem.

$\mathrm{Na}$ Figura 4 podem ser observados os valores de produção de folhedo acumulada em cada um dos quatro anos após o início da coleta.

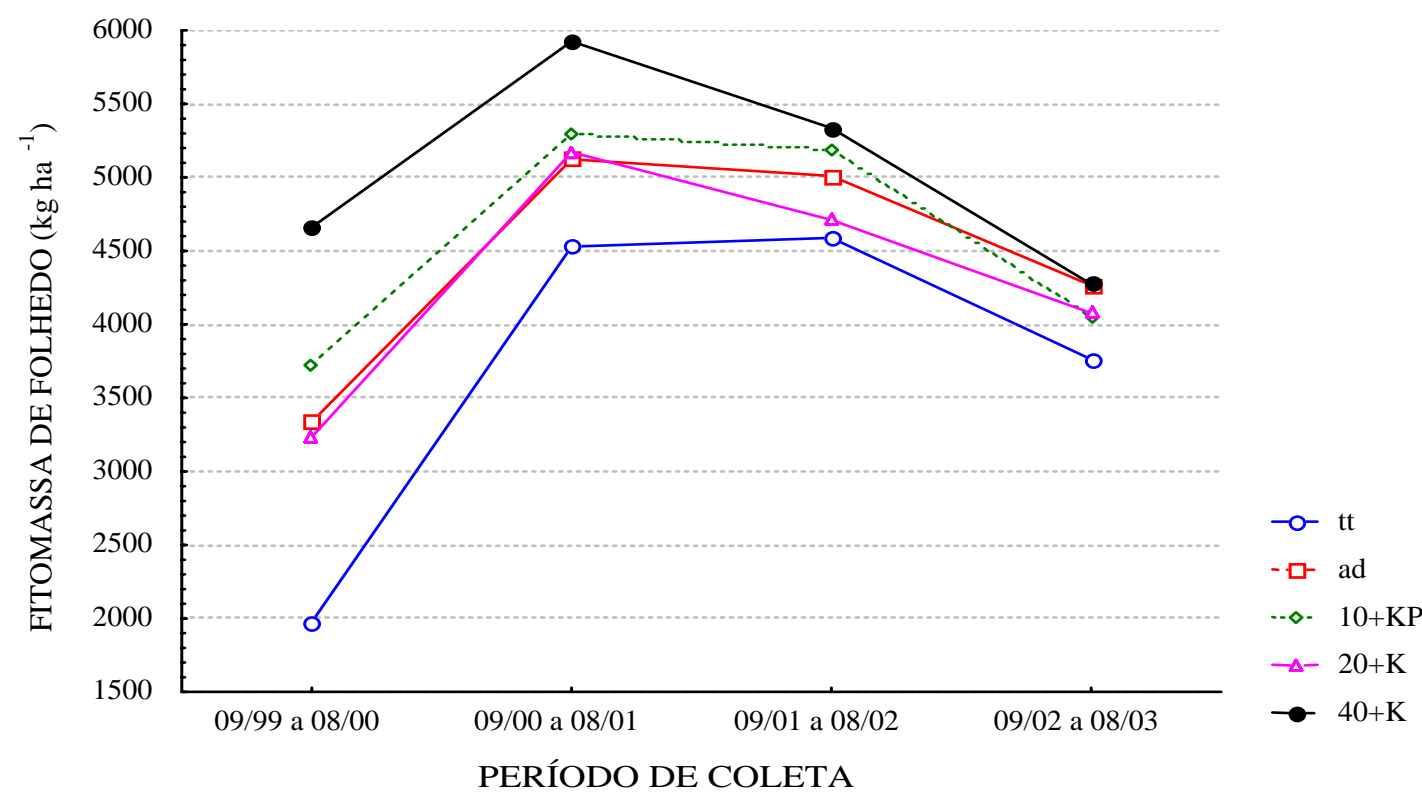

Figura 4- Valores médios $(n=48)$ de fitomassa seca de folhedo, depositado anualmente pelos eucaliptos, durante o período de setembro de 1999 a abril de 2003, nos diferentes tratamentos

Houve maior efeito da aplicação de biossólido no primeiro ano de coleta (09/1999 a 08/2000), quando a diferença entre o tratamento que recebeu a maior dose de biossólido $(40+\mathrm{K})$ e o tratamento testemunha (tt) foi de $2686 \mathrm{~kg}$ $\mathrm{ha}^{-1}$, sendo o valor do "40+K" 2,4 vezes superior do que o valor do tratamento testemunha. Já no terceiro (09/2001 a 08/2002) e quarto (09/2002 a 08/2003) ano, essa diferença foi de apenas 746 e $512 \mathrm{~kg} \mathrm{ha}^{-1}$, respectivamente. O primeiro ano de coleta ocorreu quando os eucaliptos possuíam de 1,5 a 2,5 
anos de idade, fase em que a ciclagem bioquímica ainda não se estabeleceu e há elevada demanda de nutrientes provenientes do solo para formação da copa. Com o desenvolvimento das árvores a ciclagem bioquímica passa a suprir boa parte da demanda por nutrientes e os eucaliptos são menos influenciados pela disponibilidade de nutrientes no solo e, conseqüentemente, pelos tratamentos. Outros fatores como a competição por luz, menos afetados pela aplicação do biossólido e fertilizantes minerais, passam a ser mais determinantes para a produção de folhas.

Carpanezi (1980) observou deposição de $4687 \mathrm{~kg} \mathrm{ha}^{-1} \mathrm{ano}^{-1}$ de folhas de Eucalyptus grandis aos 5 anos de idade; valor próximo aos encontrados neste trabalho, entre 4000 e $4500 \mathrm{~kg} \mathrm{ha}^{-1} \mathrm{ano}^{-1}$, para os eucaliptos que receberam adubação mineral e biossólido, no ano de coleta referente à idade entre 4,5 e 5,5 anos. Schumacher (1992), trabalhando durante o período de 1989 a 1991, encontrou valor médio de $3138 \mathrm{~kg} \mathrm{ha}^{-1} \mathrm{ano}^{-1}$ de folhedo produzido em dois anos, para Eucalyptus grandis com 7 anos de idade.

Há indícios de que a maior produção de folhedo pelas árvores do tratamento "40+K", principalmente nessa fase inicial, se deve à maior disponibilidade de $\mathrm{N}$ no solo sob este tratamento, que teria propiciado uma formação da copa mais rápida e com maior quantidade de biomassa foliar. Segundo Laclau (2003), que trabalhou com uma cronoseqüência de um clone híbrido de eucalipto, de $60 \%$ a $70 \%$ do $\mathrm{N}$ requisitado pelo eucalipto durante a rotação é destinado à produção de folhas. Como o tempo de vida médio das folhas para o clone estudado foi de seis meses, houve uma elevada demanda de nutrientes, especialmente $\mathrm{N}$, para manter a copa viva durante a rotação. $\mathrm{A}$ aplicação da dose de $40 \mathrm{Mg} \mathrm{ha}^{-1}$ de biossólido refletiu em maiores teores de $\mathrm{N}$ no próprio folhedo coletado durante todo o período de crescimento (Figura 7) e nas folhas das copas dos eucaliptos, a partir de dois meses após a aplicação do resíduo e até 2,5 anos de idade (Guedes \& Poggiani, 2003); maiores inclusive do que os eucaliptos do tratamento "10+KP" que apresentaram maior 
desenvolvimento. A ausência da disponibilidade de $\mathrm{P}$ pelo biossólido até um ano após aplicação (Guedes 2000, Vaz \& Gonçalves, 2002) fez com que as árvores do tratamento que receberam $\mathrm{P}$ mineral na base se desenvolvessem melhor após o plantio, com maiores taxas de crescimento em diâmetro e altura.

Não houve variação cíclica da produção de folhedo pelas árvores de todos os tratamentos ao longo dos anos. O que se observa, de maneira geral, é um modelo de crescimento, estabilização e queda. Esse modelo parece ser coerente com o acúmulo de fitomassa de copa pelo eucalipto e dependente da produtividade biológica, principalmente, da capacidade de produção de fitomassa foliar. Segundo Laclau (2000), que estudou uma cronoseqüência de plantações de eucalipto no Congo, a biomassa foliar do eucalipto foi formada principalmente no primeiro ano (1800 $\left.\mathrm{kg} \mathrm{ha}^{-1}\right)$, chegando a um valor máximo de $2600 \mathrm{~kg} \mathrm{ha}^{-1}$ no segundo ano, diminuindo nos anos subsequentes e mantendo valores inferiores ao primeiro ano. Neste trabalho, o segundo ano de coleta do folhedo depositado, que apresentou o maior valor de produção de fitomassa foliar senescente, se inicia quando a idade dos eucaliptos era de 2,5 anos; portanto, logo após a idade - dois anos - em que o eucalipto apresenta máxima quantidade de folhas nas copas.

Uma análise da associação existente entre a produção de folhedo e as variáveis climáticas medidas durante os quatro anos de coleta do folhedo, pode ser realizada através da observação da Tabela 5 . Nessa tabela nota-se que a única variável cuja correlação foi significativa com a produção de folhedo foi a média mensal da temperatura medida às nove horas (Ta). No entanto, essa correlação não implica em uma relação de causa e efeito e o coeficiente foi relativamente baixo, mostrando que a associação entre as duas variáveis não é muito forte e que, apenas durante parte do período a variação na produção de folhedo acompanha a variação existente na temperatura. 
Tabela 5. Coeficientes de correlação e respectivos valores de probabilidade de erro tipo 1 ( $p)$ entre os valores mensais das variáveis climáticas, temperatura atual (Ta), temperatura máxima (Tmax), temperatura mínima (Tmin), umidade relativa do ar (Ur), precipitação pluviométrica $(P)$, velocidade do vento $(V)$ e a deposição mensal de folhedo pelos eucaliptos em cada um dos cinco tratamentos. $n=38$ para velocidade do vento e $n=48$ para as demais variáveis, coletadas durante 0 período de 09/1999 a 08/2003

\begin{tabular}{cccccc}
\hline & $\mathbf{t t}$ & $\mathbf{a d}$ & $\mathbf{1 0 + K P}$ & $\mathbf{2 0 + K}$ & $\mathbf{4 0 + K}$ \\
\hline Ta & 0,52 & 0,42 & 0,48 & 0,50 & 0,49 \\
& $\mathrm{p}<0,001$ & $\mathrm{p}=0,003$ & $\mathrm{p}=0,001$ & $\underline{p}<0,001$ & $\underline{\mathrm{p}<0,001}$ \\
Tmax & 0,29 & 0,16 & 0,23 & 0,20 & 0,18 \\
& $\mathrm{p}=0,045$ & $\mathrm{p}=0,267$ & $\mathrm{p}=0,120$ & $\mathrm{p}=0,167$ & $\mathrm{p}=0,223$ \\
Tmin & 0,22 & 0,13 & 0,22 & 0,22 & 0,23 \\
& $\mathrm{p}=0,133$ & $\mathrm{p}=0,381$ & $\mathrm{p}=0,143$ & $\mathrm{p}=0,129$ & $\mathrm{p}=0,109$ \\
Ur & $-0,12$ & 0,03 & 0,06 & 0,01 & 0,10 \\
& $\mathrm{p}=0,399$ & $\mathrm{p}=0,813$ & $\mathrm{p}=0,707$ & $\mathrm{p}=0,939$ & $\mathrm{p}=0,478$ \\
$\mathbf{P}$ & 0,04 & $-0,05$ & $-0,02$ & 0,00 & $-0,03$ \\
& $\mathrm{p}=0,800$ & $\mathrm{p}=0,711$ & $\mathrm{p}=0,863$ & $\mathrm{p}=0,994$ & $\mathrm{p}=0,830$ \\
$\mathbf{V}$ & $-0,20$ & $-0,24$ & $-0,24$ & $-0,26$ & $0-, 22$ \\
& $\mathrm{p}=0,223$ & $\mathrm{p}=0,146$ & $\mathrm{p}=0,143$ & $\mathrm{p}=0,110$ & $\mathrm{p}=0,179$ \\
\hline
\end{tabular}

A associação entre a produção de folhedo e a temperatura média foi significativa para o folhedo produzido pelos eucaliptos em todos os tratamentos, com valores similares dos coeficientes de correlação. Isso mostra que essa associação não pode ser utilizada para explicar a variação entre tratamentos, até porque deve-se considerar que a temperatura foi medida na estação meteorológica e não em cada tratamento. 
O Gráfico abaixo (Figura 5) mostra a fraca associação entre a produção média mensal de folhedo pelas árvores de todos os tratamentos e a média mensal da temperatura ambiente medida às $9 \mathrm{~h}$.

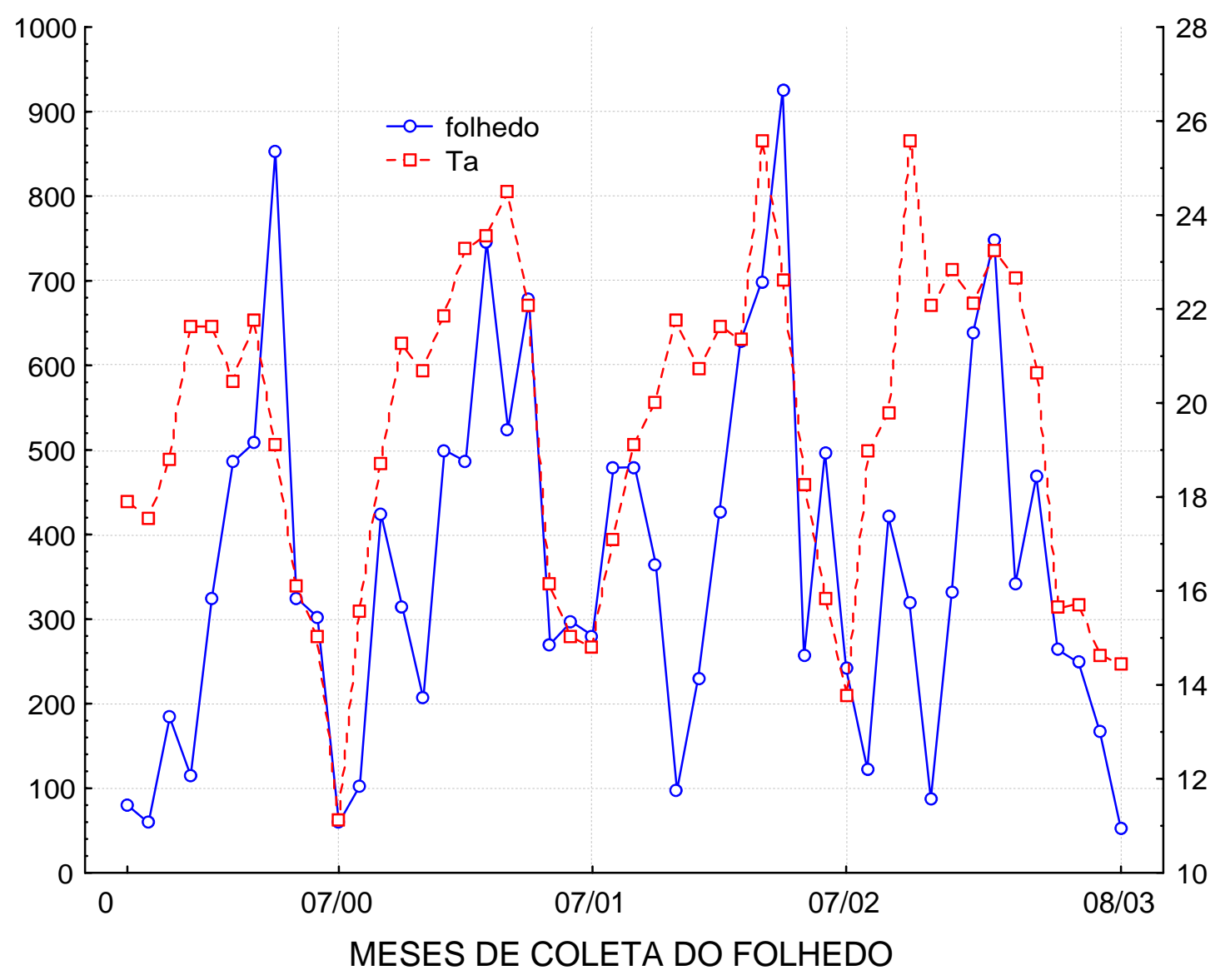

Figura 5- Valores mensais da produção média $(n=20)$ de folhedo produzido pelos eucaliptos em todos os tratamentos e da temperatura média medida às $9 \mathrm{~h}$, durante os quatro anos de coleta de folhedo, desde 09/1999 a 08/2003

A Figura 6 mostra a variação sazonal, em função das estações do ano, da produção de folhedo pelos eucaliptos de cada tratamento em cada ano. 
Como para o desenvolvimento desta tese a deposição de folhedo foi acompanhada durante quatro anos, optou-se por agrupar os valores mensais por estações e não realizar a análise de cada mês individualmente, o que dificultaria a visualização dos padrões de variação e a interpretação dos resultados. Normalmente, a avaliação da sazonalidade de deposição é realizada por diferentes autores citando períodos distintos de produção máxima e mínima de serapilheira, o que dificulta a comparação dos resultados. Essa dificuldade poderia ser amenizada se fosse padronizada a apresentação dos resultados em função das estações do ano, ficando a análise mensal para ser realizada através de estudos de correlação com as variáveis climáticas locais, conforme mostrado na Tabela 5 e Figura 5.

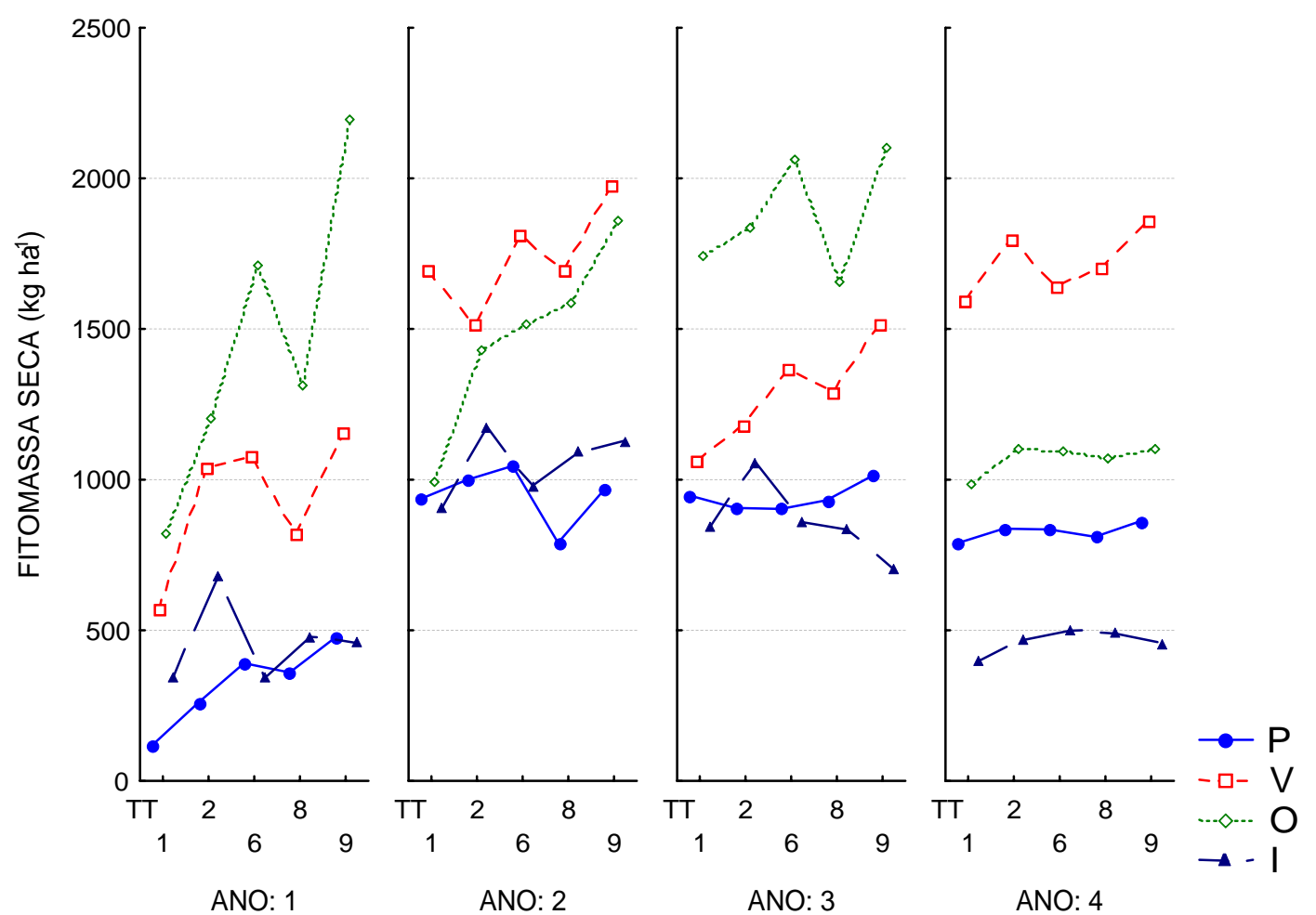

Figura 6- Valores médios $(n=12)$ da produção de folhedo pelos eucaliptos, durante as estações dos anos: $\mathrm{P}=$ primavera (setembro a novembro), 
$\mathrm{V}=$ verão (dezembro a fevereiro), $\mathrm{O}=$ outono (março a maio), I=inverno (junho a agosto); de cada um dos quatro anos de coleta, nos diferentes tratamentos: 1 (testemunha), 2 (adubação mineral), $6\left(10 \mathrm{Mg} \mathrm{ha}^{-1}\right.$ de biossólido complementadas com K e P mineral), 8 (20 Mg ha ${ }^{-1}$ de biossólido mais K mineral), 9 (40 $\mathrm{Mg} \mathrm{ha}^{-1}$ de biossólido mais $\mathrm{K}$ mineral)

Pode-se observar que, ao longo dos quatro anos de coleta, o padrão de variação em função das estações do ano foi definido por maior deposição de folhas pelos eucaliptos no verão e outono (dezembro a maio) e menor deposição no inverno e na primavera (junho a novembro), independente do tratamento. Esses resultados são parcialmente confirmados por outros trabalhos desenvolvidos com Eucalyptus em diferentes idades, no Estado de São Paulo (Carpanezi, 1980; Poggiani, 1985; Schumacher, 1992, Kolm, 2003). Esses autores encontraram maior deposição em alguns meses dentro do período envolvendo o final da primavera, verão e início do outono. Por exemplo, Kolm (2003) relata maior deposição no período de novembro a março, que coincidiu com o período chuvoso da região. Carpanezi (1980) observou maior deposição no período de dezembro a fevereiro. Schumacher (1992) observou menor deposição no período da primavera.

Apesar da constante associação da maior deposição de serapilheira com os períodos quentes e chuvosos, poucos são os trabalhos que apresentam os valores das variáveis climáticas coletadas em estação meteorológica próxima e durante a realização dos experimentos, assim como os coeficientes de correlação com essas variáveis.

Considerando as duas estações mais produtivas, houve uma alternância ao longo dos anos. Em todos os tratamentos testados, no primeiro ano de coleta a estação mais produtiva foi o outono, no segundo verão, no terceiro novamente outono e no quarto verão.

Segundo Poggiani (1985), com relação à deposição de folhedo, os eucaliptos apresentam características ecológicas que diferem da maioria das espécies que constituem as florestas nativas do interior do Estado de São 
Paulo. Ao contrário das florestas da região subtropical do Brasil, cuja deposição de folhas caducas é maior no período de inverno, os eucaliptos depositam mais folhedo no período envolvendo o final da primavera e o verão. A deposição de folhas pelos eucaliptos não estaria ligada à redução de água no solo e à necessidade de diminuir a perda de água por transpiração, mas sim devido à maior translocação de compostos orgânicos e nutrientes de tecidos mais velhos para tecidos mais novos, que ocorre no período de primavera-verão, quando a temperatura se eleva e ocorre maior desenvolvimento de folhas novas. Nessa fase, a maior brotação e o maior crescimento de folhas novas ocorreria às custas de nutrientes e hormônios antes translocados para as folhas adultas. Quando diferentes órgãos entram em competição por nutrientes durante a fase de desenvolvimento, o crescimento de um pode resultar em senescência e morte de outro (Street \& Öpik, 1974).

Apenas durante o inverno, nos três primeiros anos de coleta (Figura 6), principalmente no terceiro ano, as árvores que receberam adubação mineral completa (TT 2) apresentaram maior produção de folhedo do que as testemunhas e do que os eucaliptos que receberam biossólido. Isso pode indicar que na época do inverno, a demanda por nutrientes nos eucaliptos do "TT 2" seria maior do que nos outros tratamentos, sendo que essa demanda seria atendida através do aumento da ciclagem bioquímica dos elementos móveis devido a menor disponibilidade de nutrientes no solo por causa da diminuição da precipitação, levando a maior deposição de folhedo. O maior teor de Mg (constituinte essencial da molécula de clorofila) nos eucaliptos do "TT 2", provavelmente, permitiu a manutenção da eficiência fotossintética nessas árvores, enquanto que os eucaliptos dos outros tratamentos podem ter diminuído mais o metabolismo e a demanda por nutrientes.

$\mathrm{Na}$ Tabela 6 são relacionados todos os valores da produção mensal de folhedo ao longo do período de quatro anos. 
Tabela 6. Valores médios $(n=12)$ da produção mensal de folhedo pelos eucaliptos submetidos a diferentes tratamentos (TT), durante os quatro anos de coleta, no período de 09/1999 a 08/2003

\begin{tabular}{|c|c|c|c|c|c|c|c|c|c|c|c|c|}
\hline \multirow[b]{2}{*}{ TT } & \multicolumn{12}{|c|}{ FITOMASSA SECA DE FOLHEDO $\left(\mathrm{kg} \mathrm{ha}^{-1}\right)$} \\
\hline & set & out & nov & dez & jan & fev & mar & abr & mai & jun & jul & ago \\
\hline & \multicolumn{12}{|c|}{ ano1 } \\
\hline tt & 35 & 21 & 64 & 66 & 208 & 297 & 395 & 390 & 157 & 234 & 46 & 63 \\
\hline ad & 82 & 50 & 135 & 101 & 372 & 541 & 479 & 647 & 273 & 526 & 86 & 85 \\
\hline $10+K P$ & 127 & 62 & 201 & 117 & 380 & 567 & 564 & 986 & 398 & 199 & 51 & 95 \\
\hline $20+K$ & 74 & 68 & 218 & 121 & 274 & 425 & 492 & 744 & 340 & 296 & 57 & 126 \\
\hline \multirow[t]{2}{*}{$40+K$} & 83 & 94 & 300 & 170 & 390 & 599 & 613 & 1497 & 457 & 257 & 56 & 145 \\
\hline & \multicolumn{12}{|c|}{ ano 2} \\
\hline tt & 452 & 312 & 173 & 365 & 497 & 837 & 383 & 433 & 173 & 226 & 281 & 396 \\
\hline ad & 477 & 339 & 200 & 415 & 456 & 637 & 510 & 647 & 274 & 385 & 393 & 391 \\
\hline $10+\mathrm{KP}$ & 466 & 339 & 212 & 567 & 482 & 737 & 447 & 745 & 308 & 294 & 242 & 449 \\
\hline $20+K$ & 332 & 264 & 195 & 564 & 447 & 685 & 540 & 710 & 338 & 283 & 260 & 555 \\
\hline \multirow[t]{2}{*}{$40+K$} & 394 & 322 & 249 & 588 & 550 & 835 & 744 & 856 & 259 & 297 & 227 & 605 \\
\hline & \multicolumn{12}{|c|}{ ano 3} \\
\hline tt & 505 & 358 & 84 & 165 & 331 & 563 & 707 & 788 & 245 & 471 & 218 & 153 \\
\hline ad & 476 & 346 & 95 & 191 & 443 & 559 & 691 & 871 & 280 & 646 & 287 & 126 \\
\hline $10+K P$ & 465 & 341 & 96 & 262 & 449 & 656 & 665 & 1130 & 267 & 519 & 227 & 115 \\
\hline $20+K$ & 458 & 376 & 98 & 265 & 414 & 611 & 609 & 830 & 215 & 483 & 235 & 115 \\
\hline \multirow[t]{2}{*}{$40+K$} & 495 & 404 & 115 & 270 & 494 & 749 & 825 & 1009 & 271 & 365 & 237 & 103 \\
\hline & \multicolumn{12}{|c|}{ ano 4} \\
\hline tt & 419 & 296 & 75 & 266 & 602 & 723 & 319 & 418 & 247 & 212 & 142 & 44 \\
\hline ad & 437 & 315 & 88 & 347 & 756 & 701 & 327 & 518 & 284 & 270 & 171 & 52 \\
\hline $10+K P$ & 429 & 313 & 88 & 336 & 590 & 721 & 341 & 440 & 297 & 275 & 172 & 53 \\
\hline $20+K$ & 397 & 325 & 89 & 374 & 601 & 729 & 359 & 480 & 235 & 234 & 196 & 60 \\
\hline $40+K$ & 422 & 344 & 96 & 340 & 643 & 874 & 361 & 486 & 256 & 251 & 155 & 48 \\
\hline
\end{tabular}


A Tabela 7 mostra os valores da biomassa seca de casca e galhos produzidos pelas árvores sob diferentes tratamentos. A aplicação de tratamentos com diferentes doses de biossólido e adubações minerais, ao contrário do que ocorre para a produção de folhedo, não altera de maneira significativa (Wilks=0,5109; $F=1,0974$ e $p=0,4016$ ) a deposição de cascas e galhos das árvores.

Tabela 7. Variação na fitomassa seca anual de cascas e galhos depositados pelos eucaliptos durante o período de setembro de 2001 a agosto de 2002 (ano1) e setembro de 2002 a agosto de 2003 (ano2), em função dos tratamentos (TT). São apresentados valores anuais médios, o valor total dos dois anos $(n=4)$ e os intervalos de confiança a $95 \%$

\begin{tabular}{|c|c|c|c|c|}
\hline \multirow[b]{2}{*}{ TT } & \multirow{2}{*}{\multicolumn{2}{|c|}{$\begin{array}{c}\text { Cascas }\left(\mathrm{kg} \mathrm{ha}^{-1}\right) \\
\text { ano1 ano2 total (IC a 95\%) }\end{array}$}} & \multicolumn{2}{|c|}{ Galhos (kg ha $\left.{ }^{-1}\right)$} \\
\hline & & & ano1 ano2 & total (IC a 95\%) \\
\hline tt & 61 & $419 \underline{479}$ (192 a 767) & 35755251 & $\underline{8826}$ (7947 a 9705) \\
\hline ad & 162 & $412 \underline{573}$ (61 a 1086) & 35445524 & $\underline{9068}(6691$ a 11445$)$ \\
\hline $10+K P$ & 103 & $481 \underline{585}$ (332 a 838) & 45485907 & $\underline{10455}(8240$ a 12670$)$ \\
\hline $20+K$ & 105 & $349 \underline{455}$ (347 a 563) & 43625947 & $\underline{10309}$ (6913 a 13705) \\
\hline $40+K$ & 102 & $303 \underline{405}$ (251 a 559) & 37855937 & 9722 (6586 a 12860) \\
\hline
\end{tabular}

Pode-se observar na Tabela acima as elevadas amplitudes dos Intervalos de Confiança construídos com $95 \%$ de certeza. A grande variação dos valores em torno da média pode ser explicada por uma deposição muito irregular de cascas e galhos entre as árvores. Mesmo com quatro parcelas de $16 \mathrm{~m}^{2}$ cada não foi possível obter repetições próximas com baixa variância. Carpanezzi (1980) relata que, tradicionalmente, a mensuração da deposição de material orgânico é efetuada em bandejas de captação com área variando de 0,1 a $2 \mathrm{~m}^{2}$, tanto para folhas quanto para galhos e cascas. Segundo o autor, há dificuldades em estabelecer generalizações sobre a importância dos componentes não foliares devido às metodologias empregadas, principalmente em relação à amostragem adequada. A constatação de que frações distintas do material decíduo 
apresentam intensidades de variação distintas, tem levado, paulatinamente, à instalação de parcelas particulares para cada fração ou grupo de frações. Para as frações lenhosas, o autor descreve que não são conhecidas investigações comparativas a respeito de formas e dimensões de parcelas e cita trabalhos que utilizaram parcelas quadradas de $4 \mathrm{~m}^{2}$ e $100 \mathrm{~m}^{2}$.

Considerando as médias dos valores de deposição de cascas, galhos e folhedo pelos eucaliptos de todos os tratamentos, nos dois anos em que houve coleta simultânea desses três componentes, foram produzidos 499, 9676 e $9055 \mathrm{~kg} \mathrm{ha}^{-1}$, respectivamente, de cascas, galhos e folhedo. As quantidades de fitomassa que retornaram ao solo com a queda de galhos e folhedo foram semelhantes, sendo quase vinte vezes superior à produção de cascas.

Com a aplicação de biossólido (teor de carbono $=172 \mathrm{~g} \mathrm{~kg}^{-1}$ ), a área do tratamento "40+K" recebeu $6880 \mathrm{~kg}$ de carbono por hectare, enquanto que na área testemunha, que não recebeu o resíduo, não houve nenhum aporte. Observa-se que os eucaliptos do tratamento "40+K" depositaram, durante um período de quatro anos, valores médios totais de $4939 \mathrm{~kg} \mathrm{ha}^{-1}$ de biomassa foliar e, durante um período de dois anos, $8465 \mathrm{~kg} \mathrm{ha}^{-1}$ de cascas e galhos a mais do que as testemunhas. Considerando que 50\% desse material é constituído por carbono orgânico, a área que recebeu $40 \mathrm{Mg} \mathrm{ha}^{-1}$ foi enriquecida com 6652,5 kg de carbono. Esta quantidade é, aproximadamente, equivalente ao carbono que foi adicionado diretamente via biossólido. Como as coletas de folhedo se iniciaram ao 1,5 ano de idade e os galhos aos 3,5 anos de idade dos eucaliptos, a quantidade de serapilheira depositada anteriormente a essas idades não foi computada e, portanto, a ciclagem de $\mathrm{C}$ dentro do ecossistema com a deposição de serapilheira está subestimada. Segundo Laclau et al. (2003) a produção de serapilheira por eucalipto até 1,5 ano pode chegar a 2296 $\mathrm{kg} \mathrm{ha}^{-1}$ e a deposição de galho até o terceiro ano pode chegar a $1050 \mathrm{~kg} \mathrm{ha}^{-1}$. Considerando que nessa fase inicial é que houve maior efeito dos tratamentos, é provável que, se tivesse sido coletada essa serapilheira inicial, o maior efeito 
indireto do biossólido sobre o retorno de C para a manta florestal seria confirmado. Outro aspecto é que a avaliação atual mostra dados até os cinco anos e meio de idade. Até o final da primeira rotação, quando as árvores completarem seis ou sete anos de idade, ainda há um potencial para incrementar o efeito indireto do biossólido. Assim, considerando toda a deposição de serapilheira durante uma rotação de cultivo do eucalipto, é evidente que o efeito positivo indireto do biossólido sobre a ciclagem de material orgânico no ecossistema, devido ao incremento na produção de fitomassa de copa via fotossíntese e conseqüente retorno para a manta florestal, será maior que o próprio efeito direto da aplicação de biossólido ao solo.

A serapilheira coletada foi analisada quimicamente para estimar o retorno dos nutrientes ao solo através da queda do folhedo, cascas e galhos das árvores. Como o interesse maior deste trabalho é avaliar o retorno de nutrientes ao solo, que depende também e, principalmente, da fitomassa; em relação aos teores dos nutrientes, foram avaliados apenas alguns elementos mais afetados pelos fatores de variação (tratamentos e variação temporal ao longo dos anos de coleta) e que não apresentaram interação significativa entre os fatores. A ausência de interação significativa implica que o padrão de variação entre os tratamentos ocorre em todos os anos, assim como a variação entre os anos ocorre para todos os tratamentos.

Segundo Carpanezzi (1980), normalmente, dois fatores são apontados como responsáveis pelos teores de nutrientes em material orgânico depositado pelas árvores: as características da fertilidade química dos solos e as particularidades de nutrição mineral das espécies envolvidas. O autor acrescenta a influência do regime de chuvas, devido às quantidades expressivas de nutrientes passíveis de serem arrastados pela precipitação. Dentre as particularidades de nutrição mineral da espécie, merece ser destacada a capacidade da espécie em realizar a ciclagem bioquímica dos 
elementos de tecidos senescentes para os mais jovens em fase de crescimento. Quanto mais intensa a ciclagem bioquímica, menor será o teor do nutriente nos tecidos depositados.

Considerando o elemento $\mathrm{N}$, foram significativos os efeitos dos tratamentos $(F=26,35 ; p<0,001)$ e a variação temporal $(F=86,98 ; p<0,001)$, sendo que a interação não foi significativa ( $F=1,23 ; p=0,282)$. Na Figura 7 , a seguir, pode ser observado como os tratamentos e a variação ao longo dos anos de coleta influenciaram os teores de $\mathrm{N}$ no folhedo.

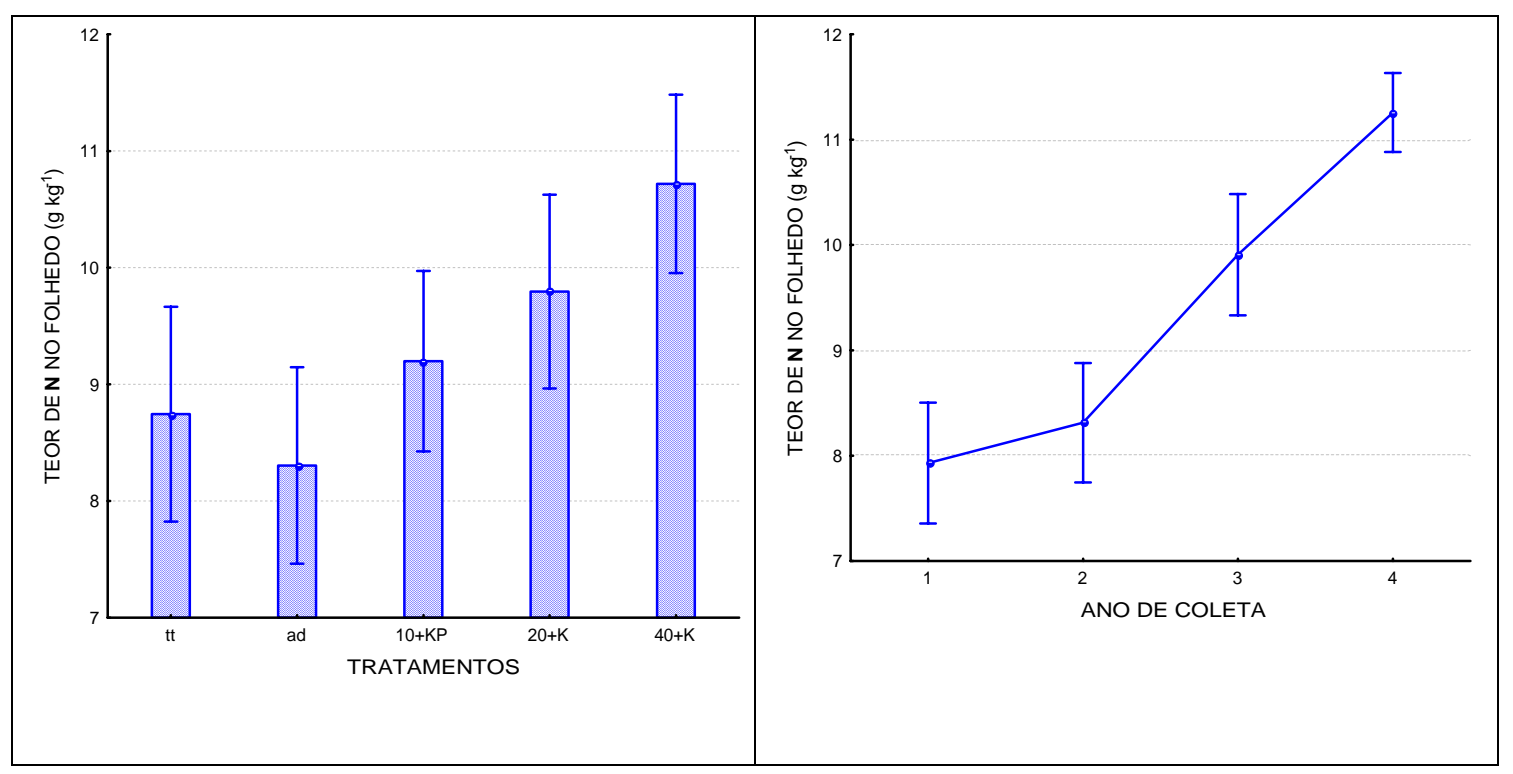

Figura 7- Variação nos valores médios do teor de $\mathbf{N}$ no folhedo depositado pelos eucaliptos, desde setembro de 1999 a agosto de 2003, em função dos diferentes tratamentos e da variação da idade das árvores ao longo dos anos de coleta. A variação em torno das médias ( $\mathrm{n}=16$ para variação por tratamento e $n=20$ para variação anual) é representada pelos intervalos de confiança construídos com 95\% de certeza.

Tratamentos: tt (testemunha), ad (adubação mineral), 10+KP $\left(10 \mathrm{Mg} \mathrm{ha}^{-1} \mathrm{de}\right.$ biossólido complementadas com K e P mineral), $20+\mathrm{K}$ (20 $\mathrm{Mg} \mathrm{ha}^{-1}$ de biossólido mais $\mathrm{K}$ mineral), $40+\mathrm{K}$ (40 Mg ha ${ }^{-1}$ de biossólido mais $\mathrm{K}$ mineral).

Anos de coleta: 1(09/1999 a 08/2000), 2 (09/2000 a 08/2001), 3 (09/2001 a 08/2002) e 4 (09/2002 a 08/2003)

Em todos os anos, as árvores que receberam a maior dose de biossólido $(40+\mathrm{K})$ produziram folhedo com maior teor de $\mathrm{N}$; enquanto as que receberam 
apenas adubação mineral produziram o folhedo com menor teor de $\mathrm{N}$. O N é um nutriente muito móvel dentro da planta e apresenta elevada ciclagem bioquímica, levando a grande retranslocação de $\mathrm{N}$ das folhas senescentes para suprir os drenos novos onde as árvores se desenvolvem. A adubação mineral, provavelmente, não foi capaz de suprir a captura de $\mathrm{N}$ pelos eucaliptos, aumentando a dependência da ciclagem bioquímica e refletindo em teores mais baixos desse elemento no folhedo. Por outro lado, os eucaliptos do tratamento onde foi aplicada a maior dose de biossólido apresentaram maior concentração de $\mathrm{N}$ no folhedo. O biossólido tem maior capacidade de atender ao requerimento dos eucaliptos por $\mathrm{N}$. Nas parcelas que receberam adubação mineral, a quantidade aplicada foi de $98 \mathrm{~kg}$ de $\mathrm{N}$ por hectare, enquanto que quando se aplicou a dose de $40 \mathrm{Mg} \mathrm{ha}^{-1}$ de biossólido houve um aporte de 760 $\mathrm{kg} \mathrm{ha}^{-1}$ de $\mathrm{N}$.

Considerando o elemento $\mathrm{Ca}$, a análise da variável transformada $\mathrm{Y}=1 / \mathrm{Ca}$ (transformação necessária para atingir homocedasticidade) mostrou que o efeito dos tratamentos foi altamente significativo $(F=190,14 ; p<0,001)$. Já, a variação temporal não é significativa quando se considera o nível de $1 \%$ de probabilidade $(F=3,84 ; p=0,014)$. Na Figura 8 é possível observar o elevado incremento nos teores de Ca com a aplicação de biossólido. 


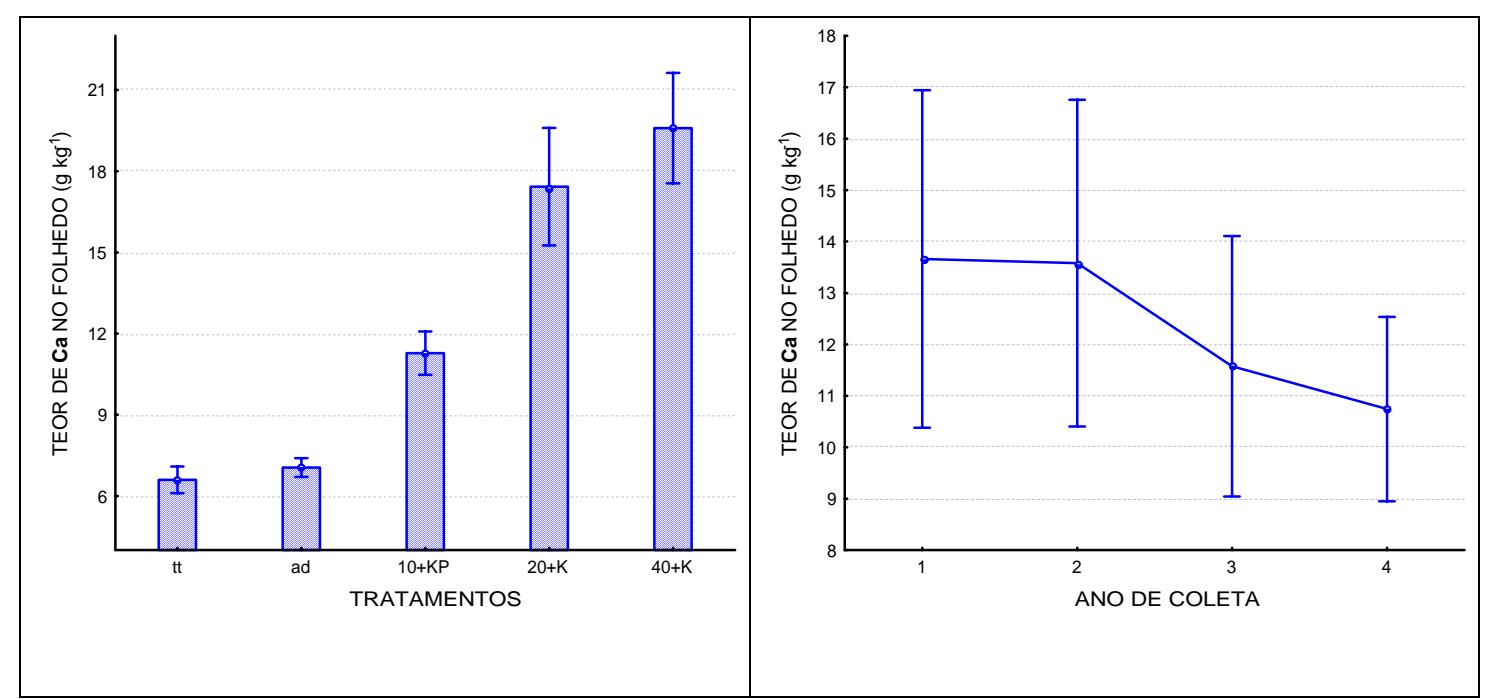

Figura 8- Variação nos valores médios do teor de Ca no folhedo depositado pelos eucaliptos, desde setembro de 1999 a agosto de 2003, em função dos diferentes tratamentos e da variação da idade das árvores ao longo dos anos de coleta. A variação em torno das médias ( $n=16$ para variação por tratamento e $n=20$ para variação anual) é representada pelos intervalos de confiança construídos com 95\% de certeza

Como o Ca é um elemento praticamente imóvel dentro da planta, que não apresenta retranslocação e se acumula nas folhas senescentes, a variação do seu teor no folhedo é função direta da quantidade do elemento absorvida pelas árvores. Como o biossólido é muito rico em $\mathrm{Ca}$, há um nítido efeito das doses aplicadas sobre os teores do nutriente no folhedo. O teor de $\mathrm{Ca}$ no folhedo produzido pelas árvores do tratamento " $40+K$ " é cerca de três vezes superior ao das árvores testemunhas e que receberam adubação mineral. A elevada variação em torno das médias de cada ano de coleta é reflexo das grandes diferenças observadas entre os tratamentos.

Considerando o elemento $\mathrm{Mg}$, foram significativos os efeitos dos tratamentos $(F=114,7 ; p<0,001)$ e a variação temporal $(F=16,8 ; p<0,001)$, sendo que a interação não foi significativa ( $F=1,70 ; p=0,102)$. Na Figura 9 pode-se observar que a aplicação de biossólido reduziu o teor de $\mathrm{Mg}$ no folhedo, tanto 
em relação aos eucaliptos que receberam fertilização mineral, quanto em relação aos eucaliptos testemunhas.

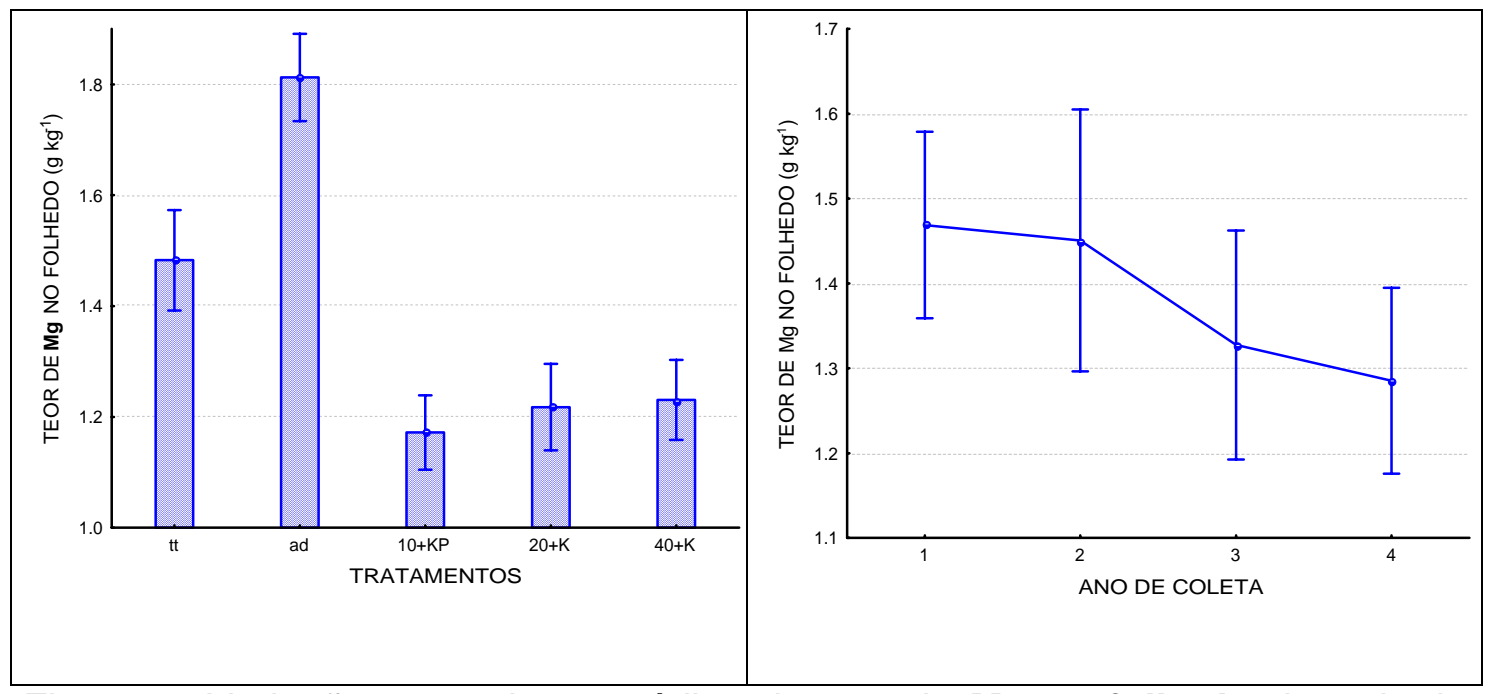

Figura 9- Variação nos valores médios do teor de $\mathbf{M g}$ no folhedo depositado pelos eucaliptos, desde setembro de 1999 a agosto de 2003, em função dos diferentes tratamentos e da variação da idade das árvores ao longo dos anos de coleta. A variação em torno das médias ( $\mathrm{n}=16$ para variação por tratamento e $n=20$ para variação anual) é representada pelos intervalos de confiança construídos com 95\% de certeza

Como o Mg apresenta baixa retranslocação interna (Laclau, 2003), os teores do elemento no folhedo coletado ao longo dos anos de cultivo representam os teores nas folhas quando elas eram metabolicamente ativas e, portanto, sua participação na nutrição da espécie. A afirmação de que a aplicação de biossólido pode diminuir a absorção de $\mathrm{Mg}$ pelas árvores é confirmada pela análise dos dados dos teores dos elementos nas folhas vivas dos eucaliptos com cinco anos de idade (Tabela 20) e também por Guedes e Poggiani (2003), que analisaram os teores foliares dos nutrientes logo após a aplicação de biossólido, nesse mesmo experimento, e encontraram que a aplicação de biossólido propiciou a diminuição do teor de $\mathrm{Mg}$ em relação à fertilização mineral. Esse fato ocorreu a partir de seis meses após aplicação e foi atribuído a uma possível competição com o elemento Ca. Em uma área dos EUA, cultivada com Abies grandis e Pseudotsuga menziesii, oito anos após a 
aplicação de $300 \mathrm{Mg} \mathrm{ha}^{-1}$ (peso seco) de lodo de esgoto, também houve sintomas de deficiência de $\mathrm{Mg}$. Analisando o tecido foliar das plantas da área testemunha, os autores encontraram um teor de $\mathrm{Mg}$ de $0,93 \mathrm{~g} \mathrm{~kg}^{-1}$, enquanto que na área tratada com lodo foi observada uma concentração de $0,25 \mathrm{~g} \mathrm{~kg}^{-1}$. Isso indica que a aplicação do lodo pode ter sido a causa de deficiência de Mg, provavelmente devido à competição por sítios de absorção exercida por outros cátions existentes no lodo em teores mais elevados que o $\mathrm{Mg}$ (Harrison et al., 1994). Anjos \& Mattiazzo (2000), trabalhando com o mesmo tipo de biossólido utilizado nesta pesquisa, encontraram que o excesso de Ca do biossólido alcalino aumenta a perda de Mg por lixiviação.

Novais \& Barros (1990) comentam que a baixa demanda de Mg para o eucalipto, faz com que a relação $\mathrm{Ca} / \mathrm{Mg}$ trocáveis ideal para seu crescimento ótimo seja bastante larga. Apesar de não ser problemático para o eucalipto, esse desbalanceamento pode trazer problemas quando se aplicar biossólidos alcalinos em culturas que exigem relação $\mathrm{Ca} / \mathrm{Mg}$ mais estreita e estável.

Considerando o elemento Mn (Figura 10), foram significativos os efeitos dos tratamentos ( $F=43,54 ; p<0,001)$ e a variação temporal $(F=21,60 ; p<0,001)$, sendo que a interação não foi significativa $(F=1,75 ; p=0,080)$. 


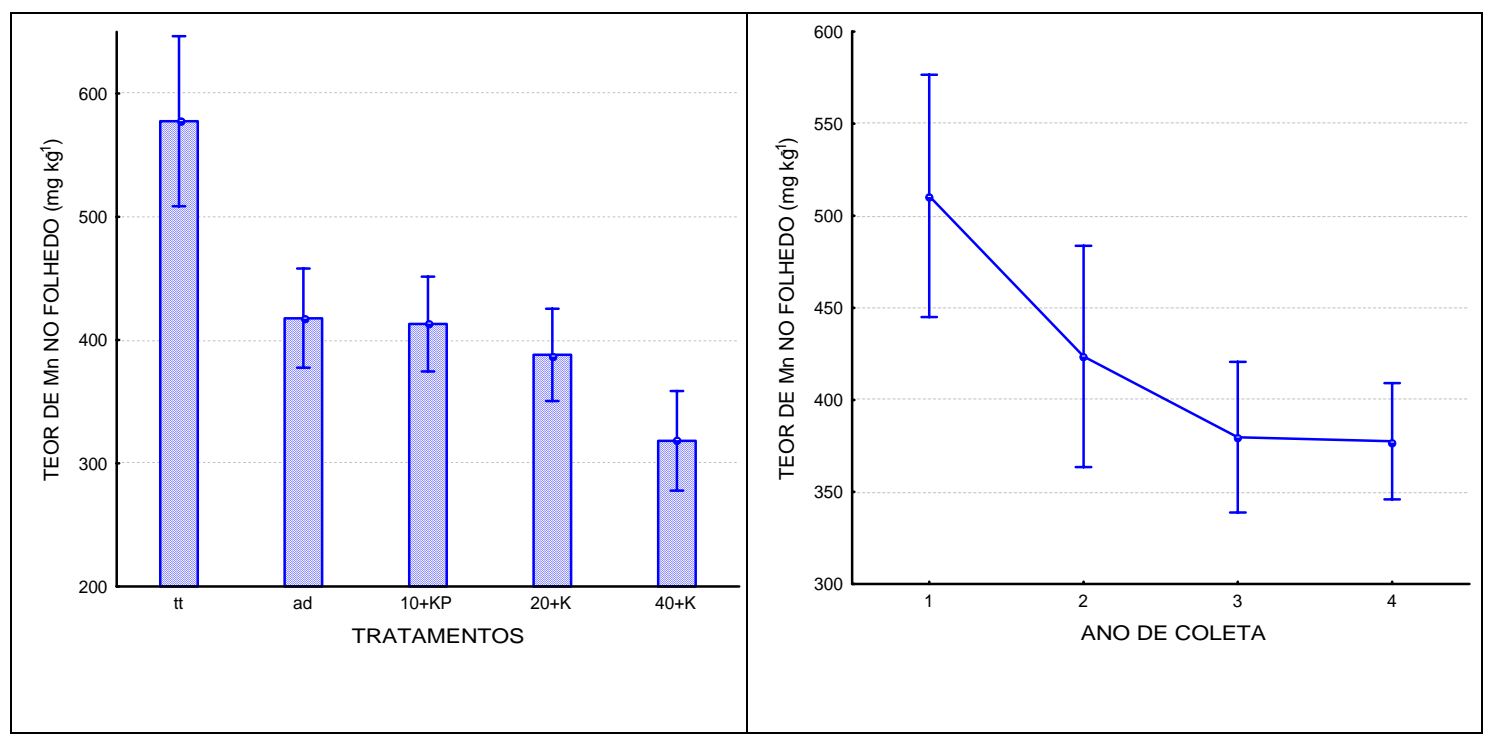

Figura 10- Variação nos valores médios do teor de Mn no folhedo depositado pelos eucaliptos, desde setembro de 1999 a agosto de 2003, em função dos diferentes tratamentos e da variação da idade das árvores ao longo dos anos de coleta. A variação em torno das médias ( $n=16$ para variação por tratamento e $n=20$ para variação anual) é representada pelos intervalos de confiança construídos com 95\% de certeza

A diminuição dos teores de Mn com o aumento das doses de biossólido normalmente é associada ao aumento do pH do solo (Tsadilas et al., 1995; Sloan e Basta, 1995; Anjos e Mattiazzo, 2000; Christie et al., 2001; Guedes e Poggiani, 2003), que permite a precipitação do Mn tornando-o indisponível às plantas. No entanto, a avaliação dos teores de $\mathrm{Mn}$ disponível para o desenvolvimento desta tese (Tabela 27) mostra que esse teor aumentou, aproximadamente, três vezes seu valor no solo que recebeu biossólido em relação aos tratamentos "tt" e "ad". Assim, a principal hipótese para explicar a diminuição na absorção de Mn pelos eucaliptos é a competição entre o Ca e o Mn durante o processo de extração dos nutrientes pelas raízes. Como ambos são cátions bivalentes com raios iônicos de tamanhos aproximados, há uma competição direta entre eles pelos sítios de absorção e o excesso de Ca pode 
ter inibido a entrada de Mn nas raízes. Segundo Guedes e Poggiani (2003), que também constataram o efeito negativo do biossólido sobre os teores de Mn nas folhas dos eucaliptos, a diminuição da concentração de $\mathrm{Mn}$ com o aumento da dose de biossólido, pode ser considerada benéfica para o eucalipto, pois, normalmente, não são observados problemas de deficiência de Mn na cultura. O que pode acontecer é problema de excesso e toxicidade, conforme constatado por Sgarby (2002). Esse autor estudou a variação na produtividade de plantações de eucalipto em função do estado nutricional e da fertilidade do solo em várias regiões do Estado de São Paulo, encontrando diminuição na produtividade nas regiões de Jacareí e Lençóis Paulista devido ao excesso de manganês.

Considerando o elemento Zn, foram significativos os efeitos dos tratamentos $(Q=46,42 ; p<0,001)$ e a variação temporal $(Q=8,22 ; p<0,042)$. Como as transformações testadas não foram eficientes para homogeneizar a variância em torno dos teores médios de Zn entre os tratamentos e entre os anos de coleta, foi utilizado um teste não paramétrico que utiliza a estatística do Qui-quadrado. Na Figura 11 pode ser observado o nítido efeito das doses de biossólido sobre o aumento dos teores de $\mathrm{Zn}$ do folhedo, assim como o aumento com o passar dos anos de coleta. Como o Zn é um elemento pouco móvel dentro da planta, suas concentrações no folhedo decíduo representam as variações nas respectivas folhas metabolicamente ativas quando vivas. Observa-se um nítido efeito do aumento das doses de biossólido sobre o incremento do teor de $\mathrm{Zn}$ no folhedo. 


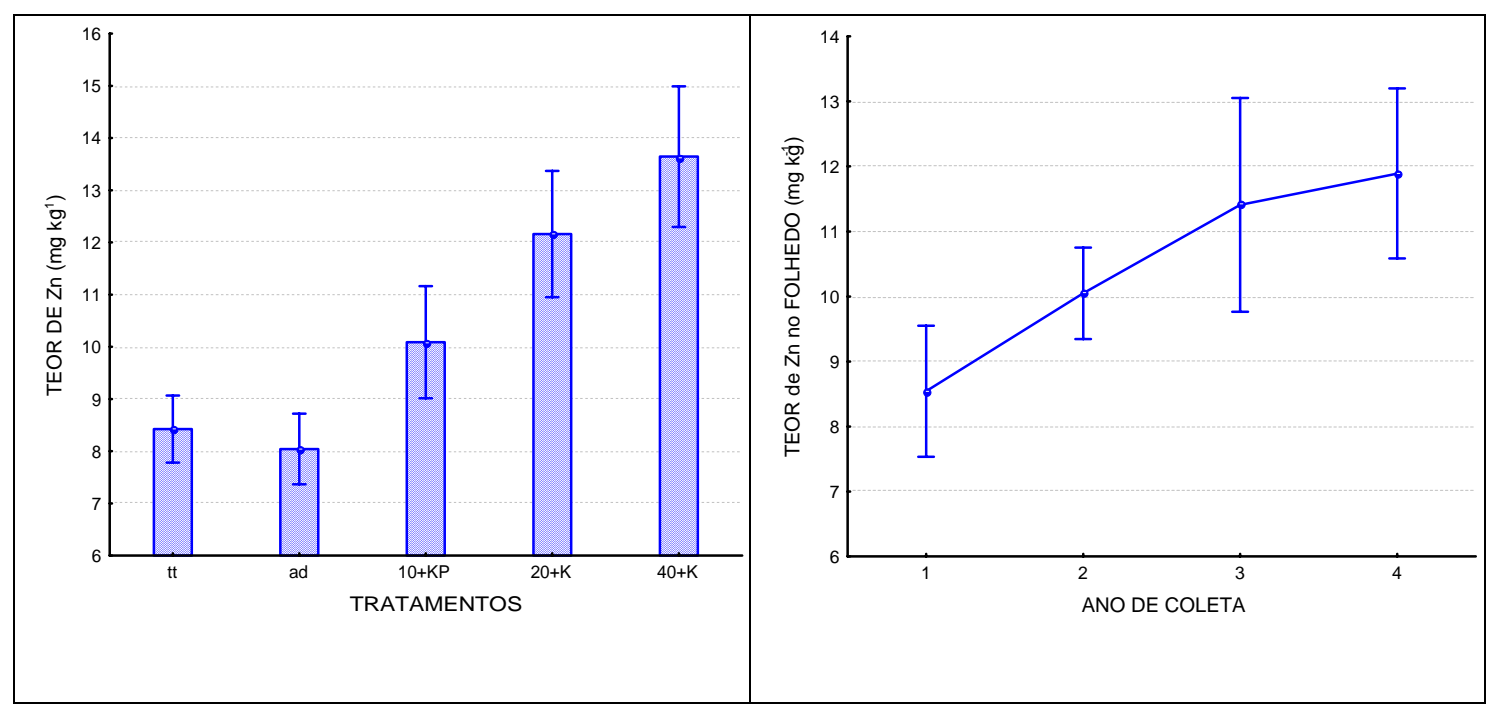

Figura 11- Variação nos valores médios do teor de Zn no folhedo depositado pelos eucaliptos, desde setembro de 1999 a agosto de 2003, em função dos diferentes tratamentos e da variação da idade das árvores ao longo dos anos de coleta. A variação em torno das médias $(n=16$ para variação por tratamento e $n=20$ para variação anual) é representada pelos intervalos de confiança construídos com 95\% de certeza

Analisando os teores de nutrientes no folhedo depositado pelos eucaliptos em relação à idade das árvores, verifica-se que o $\mathrm{N}$ e $0 \mathrm{Zn}$ aumentaram seus valores ao longo dos anos de coleta; enquanto que o $\mathrm{Ca}$, o Mg e o Mn apresentaram relação negativa com o aumento da idade dos eucaliptos e com o passar dos anos de coleta. A cada novo ano de coleta aumentou-se o teor médio anual de $\mathrm{N}$, independente dos tratamentos. $\mathrm{O}$ aumento da concentração de $\mathrm{N}$, tanto no folhedo depositado quanto nas folhas vivas das copas, com o aumento da idade de povoamentos de eucalipto foi relatado por Laclau (2003).

A Tabela 8 apresenta a média por tratamento, para cada ano de coleta, dos resultados das análises químicas para determinação dos teores dos nutrientes no folhedo. 
Tabela 8. Variação em teores de nutrientes no folhedo depositado pelos eucaliptos nos coletores de cada tratamento (TT), em cada um dos quatro anos de coleta. São apresentados valores médios de seis coletas bimestrais $x$ quatro repetições por coleta $(n=24)$

\begin{tabular}{|c|c|c|c|c|c|c|c|}
\hline \multirow[b]{2}{*}{ TT } & $\mathbf{N}$ & & $\mathrm{Ca}$ & $\mathbf{M g}$ & $\mathrm{S}$ & \multirow{2}{*}{\multicolumn{2}{|c|}{$\begin{array}{l}\text { Mn } \\
-\mathrm{Zn} \mathrm{kn}^{-1}\end{array}$}} \\
\hline & & - & $-\mathrm{g} \mathrm{kg}$ & & ---- & & \\
\hline & \multicolumn{7}{|c|}{ ano 1: set/1999 a ago/2000 } \\
\hline tt & 6,7 & 0,3 & 7,0 & 1,6 & 0,8 & 699 & 7 \\
\hline ad & 7,2 & 0,3 & 7,0 & 1,8 & 0,7 & 484 & 7 \\
\hline $10+K P$ & 7,7 & 0,4 & 11,9 & 1,2 & 0,7 & 465 & 8 \\
\hline $20+K$ & 8,7 & 0,4 & 19,6 & 1,4 & 0,7 & 480 & 10 \\
\hline \multirow[t]{2}{*}{$40+K$} & 9,3 & 0,4 & 22,8 & 1,4 & 0,9 & 427 & 11 \\
\hline & \multicolumn{7}{|c|}{ ano 2: set/2000 a ago/2001 } \\
\hline tt & 8,2 & 0,3 & 6,1 & 1,6 & 0,5 & 635 & 9 \\
\hline ad & 6,7 & 0,2 & 7,4 & 2,0 & 0,5 & 446 & 9 \\
\hline $10+K P$ & 8,1 & 0,3 & 12,5 & 1,2 & 0,5 & 393 & 9 \\
\hline $20+K$ & 8,7 & 0,3 & 19,8 & 1,2 & 0,6 & 365 & 11 \\
\hline \multirow[t]{2}{*}{$40+K$} & 9,7 & 0,4 & 22,1 & 1,3 & 0,7 & 279 & 12 \\
\hline & \multicolumn{7}{|c|}{ ano3: set/2001 a ago/2002 } \\
\hline tt & 9,0 & 0,3 & 6,4 & 1,4 & 0,7 & 512 & 8 \\
\hline ad & 8,7 & 0,3 & 6,6 & 1,8 & 0,6 & 378 & 8 \\
\hline $10+K P$ & 10,0 & 0,4 & 10,3 & 1,2 & 0,7 & 387 & 11 \\
\hline $20+K$ & 10,2 & 0,4 & 16,5 & 1,2 & 0,7 & 350 & 14 \\
\hline \multirow[t]{2}{*}{$40+K$} & 11,6 & 0,5 & 18,0 & 1,2 & 0,8 & 272 & 16 \\
\hline & \multicolumn{7}{|c|}{ ano 4: set/2002 a ago/2003 } \\
\hline tt & 11,0 & 0,3 & 6,9 & 1,4 & 0,6 & 465 & 9 \\
\hline ad & 10,6 & 0,3 & 7,1 & 1,7 & 0,6 & 367 & 9 \\
\hline $10+K P$ & 11,0 & 0,4 & 10,4 & 1,1 & 0,6 & 407 & 12 \\
\hline $20+K$ & 11,5 & 0,4 & 13,8 & 1,1 & 0,7 & 358 & 13 \\
\hline $40+K$ & 12,2 & 0,5 & 15,6 & 1,1 & 0,8 & 294 & 16 \\
\hline
\end{tabular}


De maneira geral, a ordenação dos teores de nutrientes no folhedo depositado obedeceu a seguinte seqüência: $\mathrm{Ca}>\mathrm{N}>\mathrm{Mg}>\mathrm{S}>\mathrm{P}$, exceto para os tratamentos testemunha, a partir do segundo ano de coleta, e adubação mineral, no terceiro e quarto anos, que apresentaram valores das concentrações de $\mathrm{N}>\mathrm{Ca}$. O enriquecimento do teor de $\mathrm{N}$ na serapilheira com a idade das árvores, foi suficiente para superar o $\mathrm{Ca}$ como elemento que apresenta maior concentração; porém, apenas nos tratamentos que não representam aplicação de biossólido.

Pode-se observar a seguir (Tabela 9) os teores dos nutrientes nas cascas e galhos depositados pelas árvores. Os teores de nutrientes nos galhos e cascas senescentes foram, de maneira geral e independente do tratamento, menores do que os valores reportados para o folhedo, menos para o elemento Zn, cuja concentração nas cascas decíduas foram superiores às concentrações no folhedo. 
Tabela 9. Variação nas médias $(n=8)$ anuais dos teores de nutrientes em galhos e cascas depositadas pelas árvores durante o período de setembro de 2001 a agosto de 2003, em função dos tratamentos (TT). São apresentados valores médios de duas coletas por ano $x$ quatro repetições por coleta $(n=24)$

\begin{tabular}{|c|c|c|c|c|c|c|}
\hline & $\mathbf{N}$ & $\mathbf{P}$ & $\mathrm{Ca}$ & Mg & $\mathbf{S}$ & $\mathrm{Zn}$ \\
\hline TT* & -- & $--\cdot$ & $\mathrm{g} \mathrm{kg}$ & & --- & ------mg kg ${ }^{-1}$------ \\
\hline
\end{tabular}

\begin{tabular}{|c|c|c|c|c|c|c|c|}
\hline tt & 2,6 & 0,1 & $\begin{array}{c}\text { gal } \\
4,1\end{array}$ & $\begin{array}{l}\text { anol } \\
0,5\end{array}$ & 0,2 & 358 & 6 \\
\hline ad & 2,6 & 0,1 & 4,0 & 0,7 & 0,3 & 278 & 5 \\
\hline $10+K P$ & 2,8 & 0,1 & 5,7 & 0,6 & 0,3 & 178 & 8 \\
\hline $20+K$ & 2,9 & 0,1 & 8,1 & 0,5 & 0,3 & 147 & 8 \\
\hline $40+K$ & 3,1 & 0,1 & 10,4 & 0,5 & 0,3 & 118 & 7 \\
\hline \multicolumn{8}{|c|}{ galhos, ano2 } \\
\hline tt & 2,6 & 0,1 & 2,8 & 0,4 & 0,2 & 282 & 7 \\
\hline ad & 2,5 & 0,1 & 3,7 & 0,7 & 0,2 & 242 & 7 \\
\hline $10+K P$ & 2,9 & 0,1 & 5,3 & 0,5 & 0,2 & 187 & 10 \\
\hline $20+K$ & 2,6 & 0,1 & 6,5 & 0,5 & 0,2 & 140 & 10 \\
\hline $40+K$ & 3,0 & 0,1 & 7,9 & 0,5 & 0,2 & 107 & 9 \\
\hline
\end{tabular}

\begin{tabular}{|c|c|c|c|c|c|c|c|}
\hline \multicolumn{8}{|c|}{ cascas, ano1 } \\
\hline tt & 4,3 & 0,1 & 3,0 & 0,7 & 0,2 & 296 & 10 \\
\hline ad & 4,4 & 0,2 & 3,1 & 0,9 & 0,2 & 258 & 11 \\
\hline $10+K P$ & 4,4 & 0,2 & 3,7 & 0,6 & 0,3 & 165 & 12 \\
\hline $20+K$ & 4,9 & 0,2 & 4,2 & 0,6 & 0,4 & 145 & 12 \\
\hline $40+K$ & 5,4 & 0,2 & 3,9 & 0,6 & 0,2 & 117 & 13 \\
\hline \multicolumn{8}{|c|}{ cascas, ano2 } \\
\hline tt & 4,7 & 0,1 & 2,5 & 0,6 & 0,2 & 264 & 11 \\
\hline ad & 5,9 & 0,2 & 3,0 & 1,1 & 0,2 & 200 & 22 \\
\hline $10+K P$ & 4,8 & 0,2 & 3,9 & 0,7 & 0,2 & 171 & 20 \\
\hline $20+K$ & 5,0 & 0,2 & 4,0 & 0,5 & 0,2 & 118 & 17 \\
\hline $40+K$ & 5,5 & 0,2 & 5,0 & 0,6 & 0,2 & 106 & 27 \\
\hline
\end{tabular}

*tt (testemunha), ad (adubação mineral), 10+KP (10 Mg ha ${ }^{-1}$ de biossólido complementadas com K e P mineral), $20+\mathrm{K}$ ( $20 \mathrm{Mg} \mathrm{ha}^{-1}$ de biossólido complementadas com K mineral), 40+K (40 $\mathrm{Mg} \mathrm{ha}^{-1}$ de biossólido complementadas com K mineral) 
Não houve efeito dos tratamentos sobre as concentrações dos nutrientes $\mathrm{N}, \mathrm{P}, \mathrm{Mg}, \mathrm{S}$ e Zn, nos galhos e nas cascas senescentes. No caso do N, verificase pequenos incrementos com a aplicação de biossólido, tanto para os galhos quanto para as cascas. Apenas os nutrientes $\mathrm{Ca}, \mathrm{Mn}$ e $\mathrm{Zn}$ sofreram efeito significativo dos tratamentos. O elemento $\mathrm{Zn}$ aumentou o teor nas cascas coletadas no segundo ano, quando se aplicou biossólido e também fertilização mineral.

Em relação ao $\mathrm{Ca}$, os teores foram maiores nos galhos do que nas cascas, independente do tratamento. A diferença entre os teores de $\mathrm{Ca}$ causadas pelo efeito dos tratamentos também foi maior para os galhos do que para as cascas. Normalmente, o Ca se acumula nas cascas dos eucaliptos, sendo que, pelo menos em termos de concentração era esperado um efeito maior sobre elas. Os valores médios dos teores de $\mathrm{Ca}$ nos galhos produzidos pelos eucaliptos que receberam a maior dose de biossólido foram mais de duas vezes superiores do que nos galhos testemunhas, passando de 4,1 para 10,4 e de 2,8 para $7,9 \mathrm{~g} \mathrm{~kg}^{-1}$, respectivamente, no primeiro e no segundo ano. Esses incrementos foram maiores do que os observados para as cascas. Gonçalves \& Barros (1999) apresentam valores de $\mathrm{Ca}$ em galhos depositados pelos eucaliptos igual a $4,3 \mathrm{~g} \mathrm{~kg}^{-1}$.

Em relação ao $\mathrm{Mn}$, tanto nas cascas quanto nos galhos senescentes, também podem ser observadas diminuições nos teores com a adubação mineral e com o aumento das doses de biossólido, confirmando o padrão de variação que foi observado no folhedo e nas folhas das copas.

Multiplicando-se os teores de nutrientes pela fitomassa seca depositada em cada período é possível calcular os estoques de nutrientes nos componentes das árvores e na serapilheira produzida. Nos gráficos das figuras 12 a 16 podem ser observados o conteúdo de nutrientes transferidos ao solo através da produção de folhedo durante os quatro anos de observações. 
O efeito dos tratamentos sobre o conteúdo total de $\mathrm{N}$ contido ne folhedo foi estatisticamente significativo $(F=18,76 ; p<0,001)$. Houve maior transferência de $\mathrm{N}$ com a queda das folhas das árvores que receberam a maior dose de biossólido, $40 \mathrm{Mg} \mathrm{ha}^{-1}$ (Figura 12). Prescott et al. (1993b) também encontraram maior quantidade de N em "litter" de Pseudotsuga menziesii, dez anos após a aplicação de biossólido.

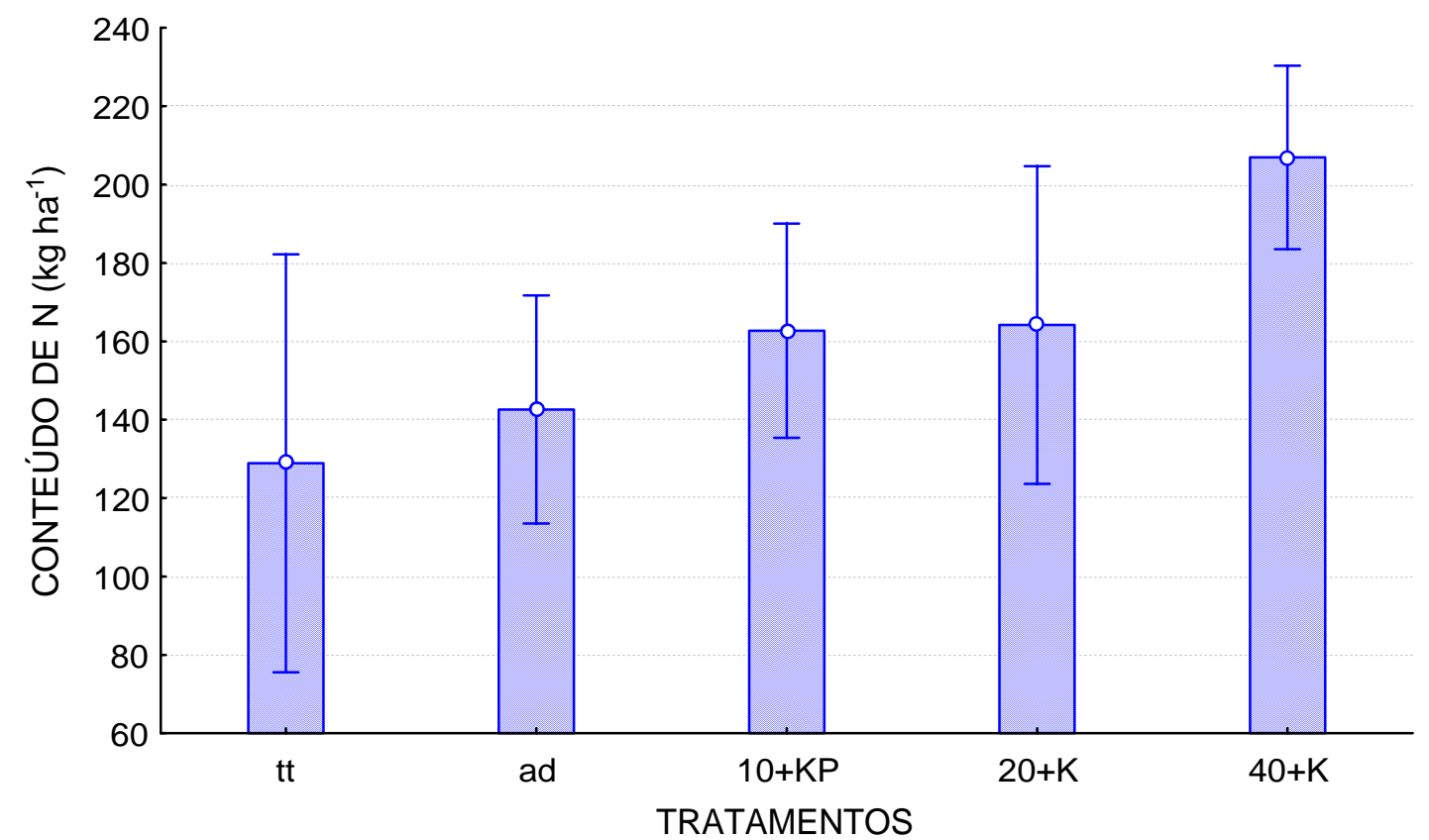

Figura 12- Variação no conteúdo total de $\mathbf{N}$ que retornou ao solo com a deposição de folhedo pelos eucaliptos, durante quatro anos de coleta (09/1999 a 08/2003), em função dos tratamentos: tt (testemunha), ad (adubação mineral), $10+K P$ (10 $\mathrm{Mg}^{-1}$ de biossólido complementadas com K e P mineral), $20+K$ (20 Mg ha ${ }^{-1}$ de biossólido complementadas com $\mathrm{K}$ mineral), $40+\mathrm{K} \quad\left(40 \mathrm{Mg} \mathrm{ha}^{-1}\right.$ de biossólido complementadas com K mineral). São apresentados valores médios $(n=4)$ e os respectivos intervalos de confiança a $95 \%$

O conteúdo total de $\mathrm{N}$, no tratamento "40+K" foi de $207 \mathrm{~kg} \mathrm{ha}{ }^{-1}$, implicando em uma taxa de retorno média de $52 \mathrm{~kg} \mathrm{ha}^{-1} \mathrm{ano}^{-1}$. Os eucaliptos que receberam fertilização mineral retornaram ao solo $143 \mathrm{~kg} \mathrm{ha}^{-1}$ de N com a deposição de folhedo durante os quatro anos, implicando em uma taxa média 
de $36 \mathrm{~kg} \mathrm{ha}^{-1}$ ano-1. Esses resultados são coerentes com os apresentados na literatura. Carpanezi (1980) encontrou $40 \mathrm{~kg} \mathrm{ha}^{-1} \mathrm{ano}^{-1}$, considerando a mesma espécie e variação de idade anterior. Binkley et al. (1992) encontraram 35 kg $\mathrm{ha}^{-1} \mathrm{ano}^{-1}$ de $\mathrm{N}$ reciclado anualmente com a queda de serapilheira fina em um plantio de Eucalyptus saligna. Kolm \& Poggiani (2003) mostram valores de 73 $\mathrm{kg} \mathrm{ha}^{-1} \mathrm{ano}^{-1}$ de $\mathrm{N}$ com a queda de serapilheira (folhas, cascas e ramos com diâmetro $<1 \mathrm{~cm}$ ) de $E$. grandis com vinte anos de idade.

O conteúdo total de $\mathrm{Ca}$ no folhedo depositado durante quatro anos, foi afetado de maneira extremamente significativa pelos tratamentos ( $F=79,44$; $\mathrm{p}<0,001)$. O Ca foi o único nutriente, dentre os analisados, que apresentou diferenças significativas em função dos tratamentos com doses crescentes de biossólido e incrementos positivamente correlacionados com as doses aplicadas (Figura 13).

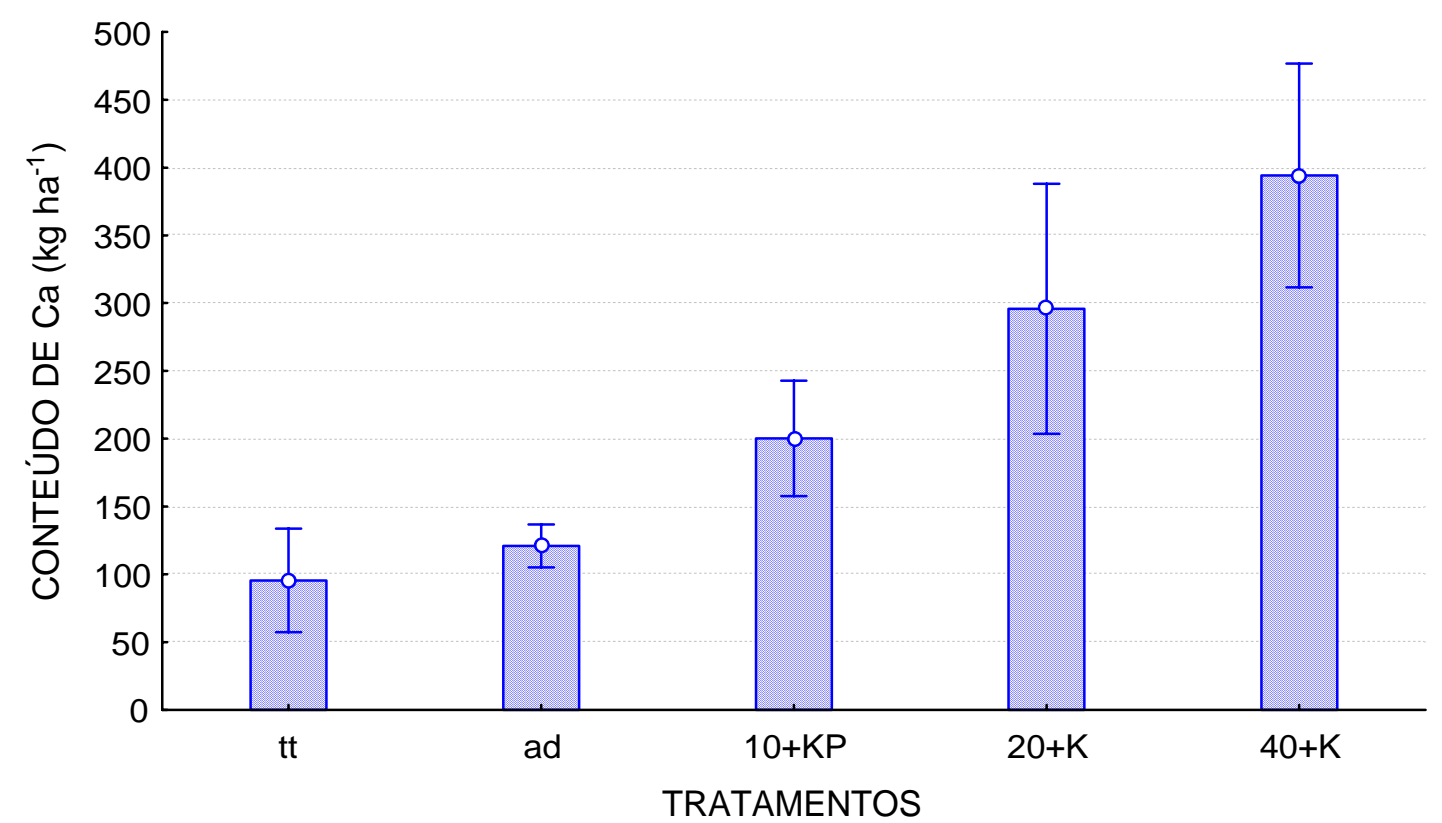

Figura 13. Variação no conteúdo total de Ca que retornou ao solo com a deposição de folhedo pelos eucaliptos, durante quatro anos de coleta (09/1999 a 08/2003), em função dos tratamentos. São apresentados valores médios $(n=4)$ e os respectivos intervalos de confiança a $95 \%$ 
Os resultados dos trabalhos citados anteriormente (Carpanezi, 1980; Poggiani, 1985; Kolm \& Poggiani, 2003) mostram, respectivamente, os seguintes valores de conteúdo de Ca: 35, 59, 47 e $79 \mathrm{~kg} \mathrm{ha}^{-1}$ ano- $^{-1}$. Observando-se os intervalos de confiança para as médias dos tratamentos testemunha e adubação mineral, verifica-se que não houve diferença significativa, considerando um nível de certeza de 95\%, entre esses tratamentos. Por outro lado, as médias dos tratamentos que representam diferentes doses de aplicação do biossólido apresentam incrementos significativos até $1 \%$ de probabilidade, conforme pode ser observado na Tabela 10.

Tabela 10. Matriz com os valores de "p value" originados da comparação, pelo teste de Tukey, entre as médias dos tratamentos (TT), para a variável resposta conteúdo total de Ca depositado durante quatro anos de coleta do folhedo. São apresentados entre parênteses os valores médios $(n=4)$ para cada tratamento

\begin{tabular}{cccccc}
\hline TT & $\begin{array}{c}\text { tt } \\
(95,51)\end{array}$ & $\begin{array}{c}\text { ad } \\
(120,96)\end{array}$ & $\begin{array}{c}\text { 10+KP } \\
(200,25)\end{array}$ & $\begin{array}{c}\text { 20+K } \\
(295,85)\end{array}$ & $\begin{array}{c}\text { 40+K } \\
(394,24)\end{array}$ \\
\hline tt & $*$ & 0,702 & 0,001 & $<0,001$ & $<0,001$ \\
ad & & $*$ & 0,012 & $<0,001$ & $<0,001$ \\
10+KP & & $*$ & 0,003 & $<0,001$ \\
$\mathbf{2 0 + K}$ & & & $*$ & 0,002 \\
$\mathbf{4 0 + K}$ & & & & & $*$ \\
\hline
\end{tabular}

$\mathrm{Na}$ Figura 14 podem ser observados os efeitos significativos dos tratamentos sobre o conteúdo de $P(F=26,83 ; p<0,001), M g(F=11,60 ; p<0,001)$ e $S$ $(F=25,74 ; p<0,001)$. 


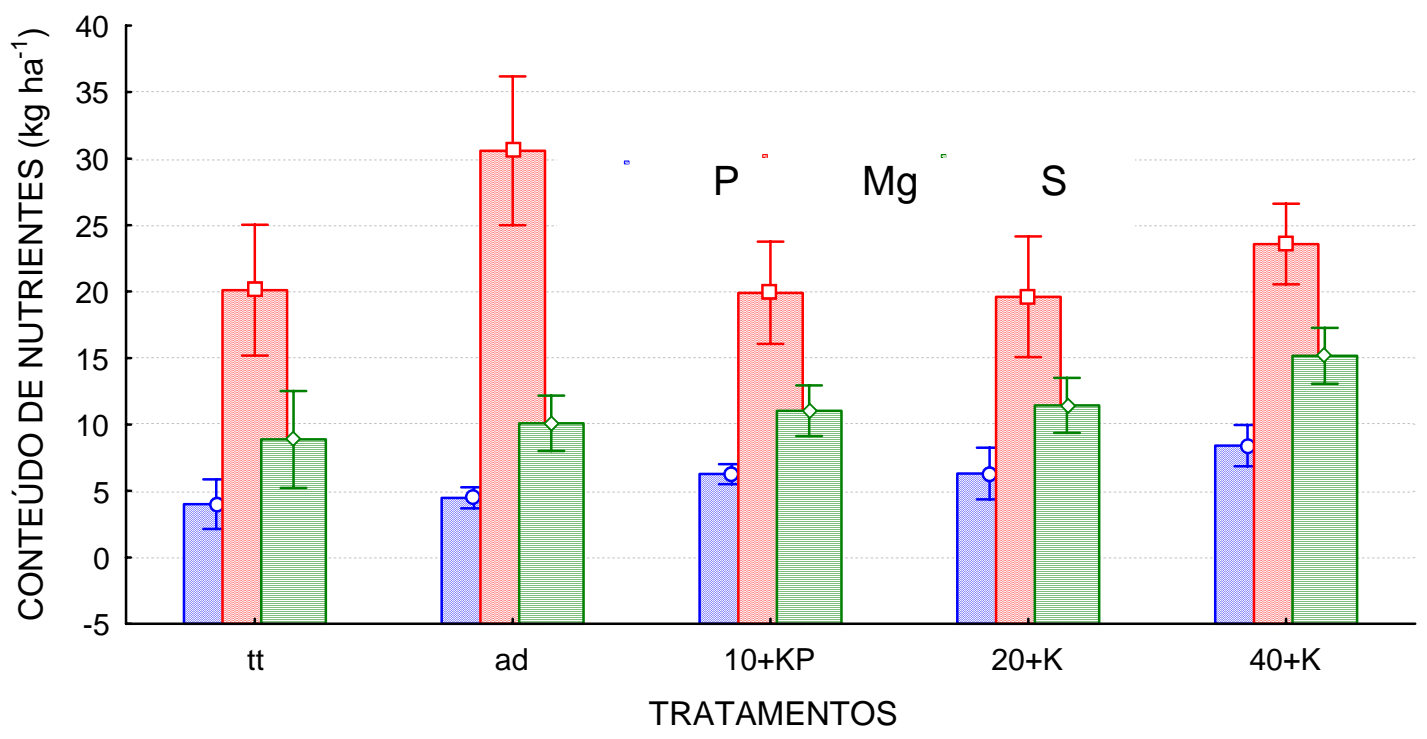

Figura 14- Variação no conteúdo total de $\mathbf{P}, \mathbf{M g}$ e $\mathbf{S}$ que retornou ao solo com a deposição de folhedo pelos eucaliptos durante quatro anos de coleta (09/1999 a 08/2003), em função dos tratamentos. São apresentados valores médios $(n=4)$ e os respectivos intervalos de confiança a $95 \%$

Considerando um nível de confiança de 95\%, verifica-se que apenas o tratamento "40+K" apresentou valores de conteúdo de $\mathrm{P}$ e $\mathrm{S}$ superiores aos demais tratamentos e que, em relação ao $\mathrm{Mg}$, os tratamentos que receberam biossólido apresentaram conteúdo médios iguais ao tratamento testemunha e inferiores ao tratamento adubação mineral.

O conteúdo médio de $\mathrm{P}$ nesse tratamento $\left(8,4 \mathrm{~kg} \mathrm{ha}^{-1}\right)$ foi mais de duas vezes superior ao do tratamento testemunha $\left(4,0 \mathrm{~kg} \mathrm{ha}^{-1}\right)$. No entanto, são valores baixos, que representam uma taxa de transferência de $2 \mathrm{~kg} \mathrm{ha}^{-1} \mathrm{ano}^{-1}$ quando se aplica a dose de $40 \mathrm{t} \mathrm{ha}^{-1}$ de biossólido e que, com isso, pouco contribuem para a manutenção do estoque e da disponibilidade de $\mathrm{P}$ na manta florestal e no solo. O P é citado por alguns autores (Attiwill, 1980; Kolm \& Poggiani, 2003; Laclau, 2003) como o macronutriente que apresenta menor teor e menor taxa de retorno com a queda de serapilheira de eucaliptos. Isso é fruto 
do baixo requerimento do nutriente pelas árvores de eucalipto, principalmente na fase adulta, em virtude da elevada retranslocação interna, que faz com que o $P$ seja o macronutriente mais eficientemente utilizado pelos eucaliptos, que pouco dependem da reciclagem biogeoquímica para esse atendimento. Da recomendação de adubação de $40 \mathrm{~kg} \mathrm{ha}^{-1}$ de $\mathrm{P}$ na base do plantio de mudas de eucalipto, pequena quantidade é realmente utilizada pelas mudas, sendo que a maior parte será adsorvida no solo, principalmente quando se tratar de Latossolos muito intemperizados com elevados teores de óxidos de Fe e Al.

O conteúdo médio de $S$ no tratamento "40+K" $\left(15,2 \mathrm{~kg} \mathrm{ha}^{-1}\right)$ foi quase duas vezes superior ao do tratamento testemunha $\left(8,9 \mathrm{~kg} \mathrm{ha}^{-1}\right)$.

Considerando o elemento $\mathrm{Mn}$, a análise da variável transformada $\mathrm{Y}=1 / \mathrm{Mn}$ (transformação necessária para atingir homocedasticidade) mostrou que não houve efeito significativo dos tratamentos $(F=1,85 ; p=0,184)$.

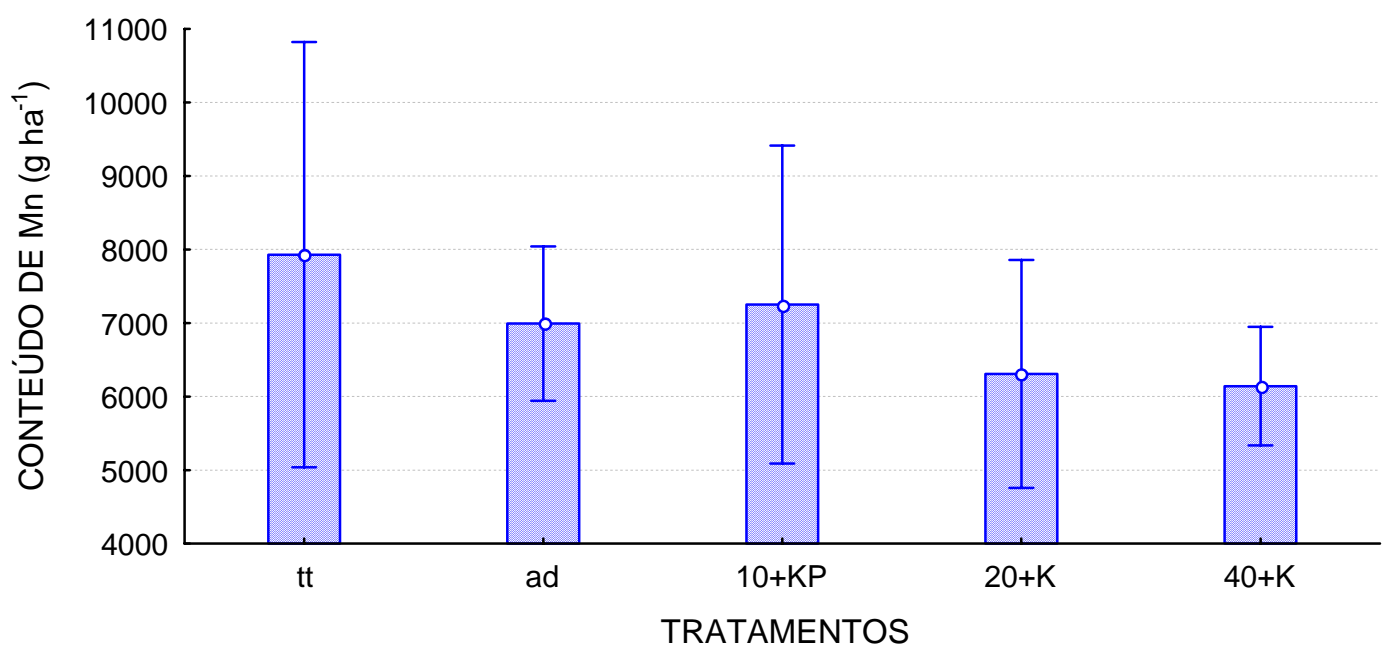

Figura 15- Variação no conteúdo total de Mn que retornou ao solo com a deposição de folhedo pelos eucaliptos, durante quatro anos de coleta (09/1999 a 08/2003), em função dos tratamentos. São apresentados valores médios $(n=4)$ e os respectivos intervalos de confiança a $95 \%$ 
Apesar de não significativa, observa-se tendência de diminuição do conteúdo de $\mathrm{Mn}$ com a aplicação dos tratamentos, mesmo com maior produção de folhedo pelos eucaliptos tratados em relação às árvores testemunhas, refletindo a menor absorção desse nutriente pelos eucaliptos quando se aplica biossólido e adubação mineral.

As diferenças entre as médias dos diversos tratamentos, para o conteúdo de $\mathrm{Zn}$ no folhedo produzido foi estatisticamente significativa ( $F=46,70$; $p<0,001)$, conforme pode ser observado na Figura 16.

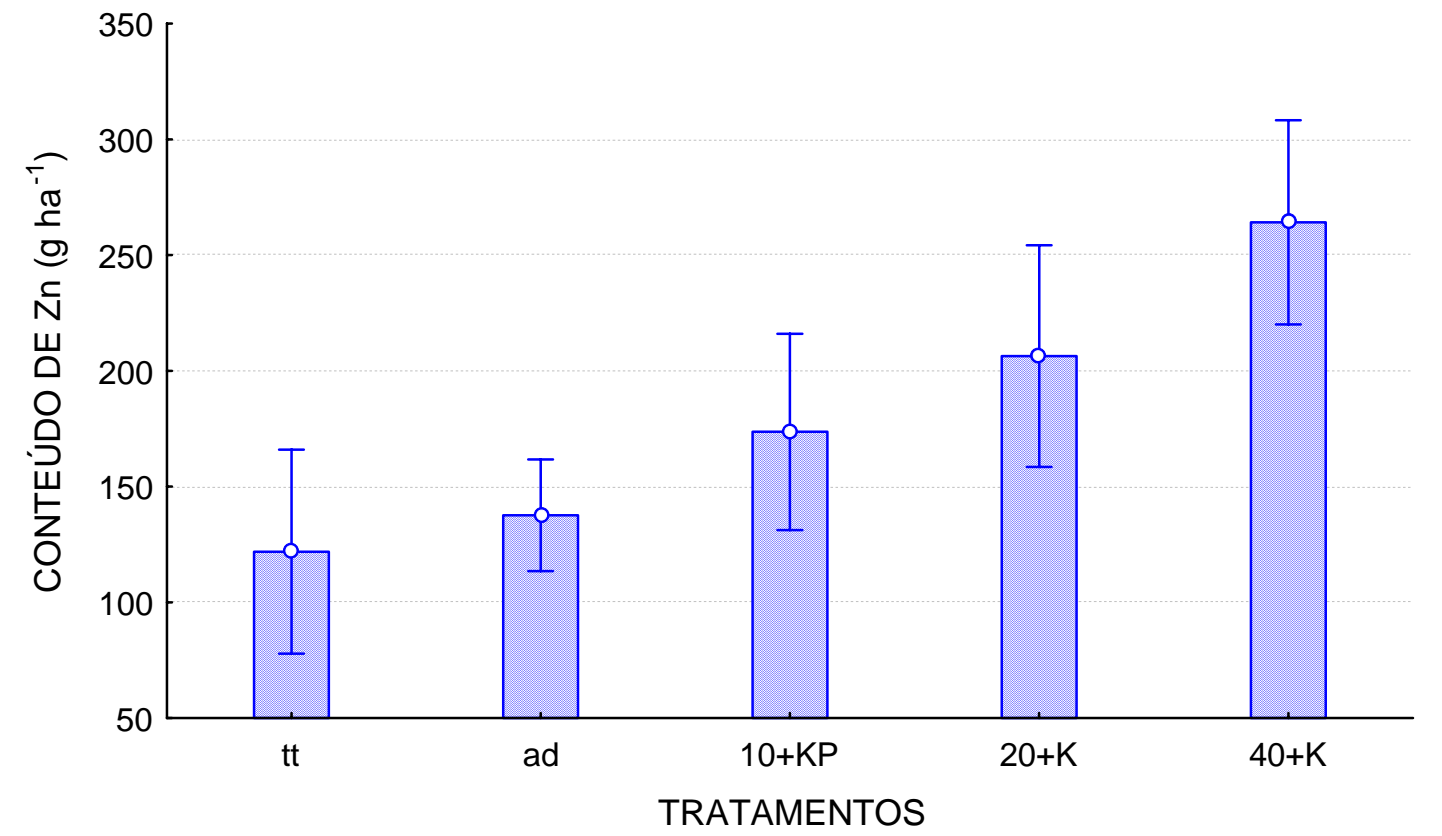

Figura 16- Variação no conteúdo total de $\mathbf{Z n}$ que retornou ao solo com a deposição de folhedo pelos eucaliptos, durante quatro anos de coleta (09/1999 a 08/2003), em função dos tratamentos. São apresentados valores médios $(n=4)$ e os respectivos intervalos de confiança a $95 \%$

As árvores que receberam biossólido apresentaram maiores taxas de transferência, das folhas senescentes das copas para a manta florestal acumulada sobre o solo, do elemento $\mathrm{Zn}$, do que as árvores testemunhas e que receberam adubação mineral. Considerando um intervalo de confiança de 95\% 
em torno das médias, observa-se que a média do tratamento " $40+K$ " foi estatisticamente superior às dos tratamentos "10+KP" e "20+K", que não apresentaram diferenças significativas entre si. A média do tratamento " $40+K$ " foi superior às médias de todos os outros tratamentos em níveis menores que 1\% de probabilidade (Tabela 11).

Tabela 11. Matriz com os valores de "p value" originados da comparação, pelo teste de Tukey, entre as médias dos tratamentos (TT), para a variável resposta conteúdo total de $\mathbf{Z n}$ depositado durante quatro anos de coleta do folhedo. São apresentados os valores médios $(n=4)$ para cada tratamento entre parênteses

\begin{tabular}{cccccc}
\hline TT & $\begin{array}{c}\text { tt } \\
(122)\end{array}$ & $\begin{array}{c}\text { ad } \\
(138)\end{array}$ & $\begin{array}{c}\text { 10+KP } \\
(174)\end{array}$ & $\begin{array}{c}\mathbf{2 0 + K} \\
(206)\end{array}$ & $\begin{array}{c}\mathbf{4 0 + K} \\
(264)\end{array}$ \\
\hline $\mathbf{t t}$ & $*$ & 0,677 & 0,006 & $<0,001$ & $<0,001$ \\
$\mathbf{a d}$ & & $*$ & 0,063 & $<0,001$ & $<0,001$ \\
$\mathbf{1 0 + K P}$ & & $*$ & 0,010 & $<0,001$ \\
$\mathbf{2 0 + K}$ & & & $*$ & 0,003 \\
$\mathbf{4 0 + K}$ & & & & & $*$ \\
\hline
\end{tabular}

Analisando os dois macronutrientes com maiores conteúdos no folhedo depositado pelos eucaliptos, verifica-se que as quantidades de $\mathrm{Ca}$ e $\mathrm{N}$ foram sempre superiores a $80 \%$ do conteúdo total dos macronutrientes devolvidos ao solo durante os quatro anos, independente do tratamento e da idade do povoamento. Considerando a média de todos os anos, os valores de $\mathrm{N}$ foram superiores aos de Ca nos tratamentos "tt" e "ad" e inferiores nos tratamentos que receberam biossólido, sendo que a diferença entre $\mathrm{Ca}$ e $\mathrm{N}$ nos tratamentos com biossólido se eleva com o aumento da dose aplicada (Figura 17). 


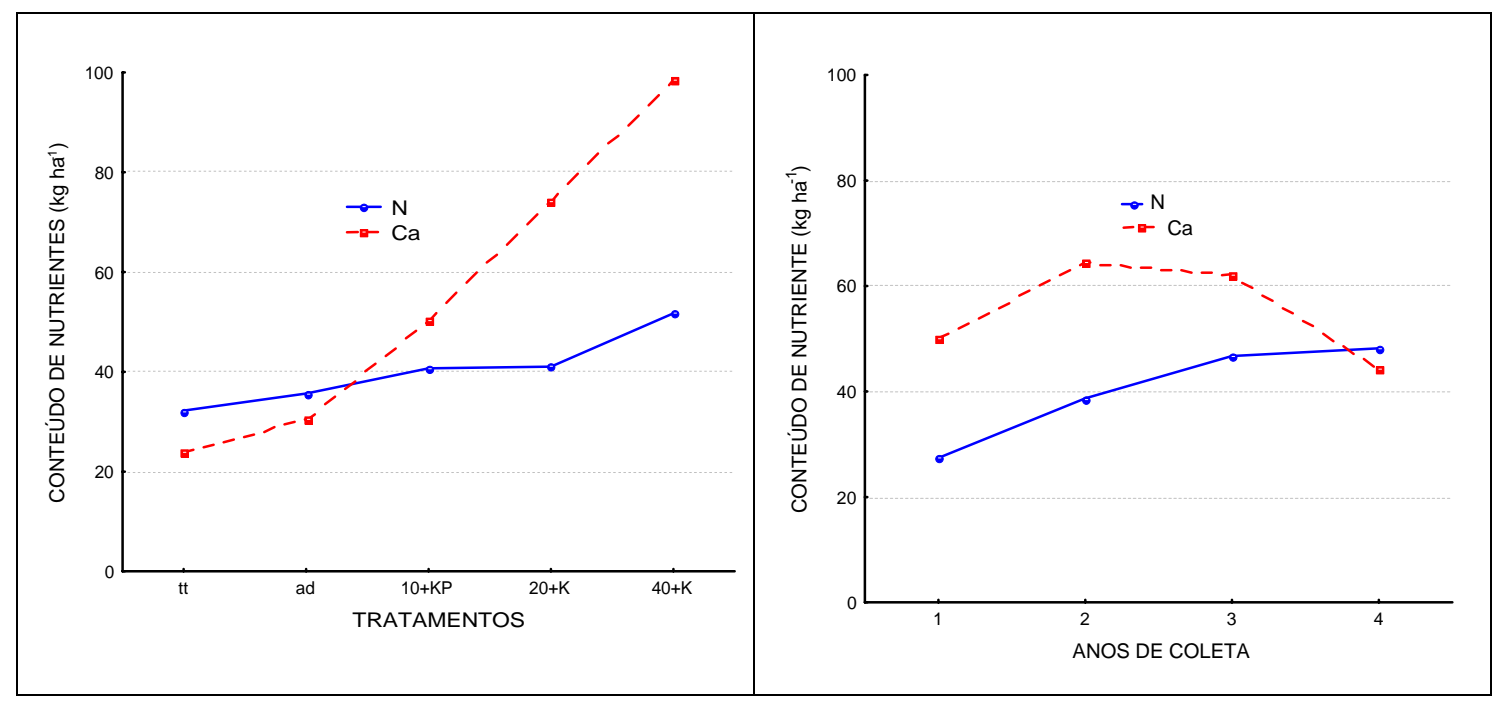

Figura 17- Variação dos conteúdos de Ca e $\mathrm{N}$ no folhedo depositado pelos eucaliptos, em função dos tratamentos (médias de todas os anos) e das épocas de coleta que refletem a idade das árvores (médias de todos os tratamentos)

Considerando a média de todos os tratamentos, a curva do conteúdo de $\mathrm{Ca}$ depositado é semelhante à curva de fitomassa de folhedo (Figura 4), apresentando valor máximo no segundo ano e decrescente a partir daí. Isso mostra que o conteúdo de Ca foi correlacionado com a fitomassa, fato este que não aconteceu para o elemento N. Esse nutriente apresenta valores crescentes com o aumento da idade dos eucaliptos, refletindo o aumento nos teores de $\mathrm{N}$ no folhedo com a idade das árvores. Isso mostra que, para o N, os teores no folhedo contribuíram mais do que a fitomassa para a variação no conteúdo que retornou para a manta florestal.

No primeiro ano de coleta, os valores dos conteúdos de $\mathrm{N}$ e Ca foram iguais para os tratamentos testemunha e adubação mineral, mantiveram-se iguais no segundo ano para o tratamento "ad", sendo que em ambos os anos os valores médios de $\mathrm{Ca}$ foram superiores ao de $\mathrm{N}$ nos tratamentos que 
receberam biossólido. A diferença entre o Ca e $\mathrm{N}$ foi máxima no segundo ano, para o tratamento "40+K" que recebeu a maior dose de biossólido (Tabela 12).

Tabela 12. Variação no conteúdo anual de nutrientes que retornou ao solo com a deposição de folhedo pelos eucaliptos, durante cada um dos quatro anos de coleta (setembro de 1999 a agosto de 2003), em função dos tratamentos

\begin{tabular}{|c|c|c|c|c|c|c|c|}
\hline TT & $\mathrm{N}$ & $P$ & $\begin{array}{l}\mathrm{Ca} \\
---k g\end{array}$ & Mg & $S$ & $M n$ & $\mathrm{Zn}$ \\
\hline & \multicolumn{7}{|c|}{ ano1: set/1999 a ago/2000 } \\
\hline tt & 13,5 & 0,5 & 13,7 & 3,2 & 1,6 & 1329 & 14 \\
\hline ad & 24,2 & 1,1 & 23,4 & 6,0 & 2,3 & 1606 & 22 \\
\hline $10+K P$ & 28,5 & 1,5 & 44,7 & 4,5 & 2,6 & 1755 & 29 \\
\hline $20+K$ & 27,9 & 1,2 & 62,6 & 4,4 & 2,3 & 1545 & 32 \\
\hline $40+K$ & 43,1 & 1,7 & 106,3 & 6,4 & 4,0 & 1987 & 52 \\
\hline & \multicolumn{7}{|c|}{ ano2: set/2000 a ago/2001 } \\
\hline tt & 32,3 & 1,0 & 23,4 & 6,1 & 1,7 & 2486 & 35 \\
\hline ad & 30,0 & 0,9 & 32,8 & 8,7 & 2,1 & 1956 & 36 \\
\hline $10+K P$ & 38,9 & 1,4 & 57,1 & 5,4 & 2,3 & 1783 & 43 \\
\hline $20+K$ & 40,6 & 1,6 & 92,0 & 5,6 & 2,8 & 1675 & 52 \\
\hline $40+K$ & 51,7 & 2,1 & 117,3 & 6,6 & 3,7 & 1444 & 66 \\
\hline & \multicolumn{7}{|c|}{ ano3: set/2001 a ago/2002 } \\
\hline tt & 39,7 & 1,2 & 32,7 & 6,0 & 3,3 & 2412 & 34 \\
\hline ad & 41,3 & 1,2 & 34,0 & 8,9 & 3,0 & 1941 & 35 \\
\hline $10+K P$ & 48,8 & 1,8 & 56,5 & 5,8 & 3,8 & 2150 & 49 \\
\hline $20+K$ & 46,0 & 1,9 & 84,1 & 5,4 & 3,7 & 1696 & 60 \\
\hline $40+K$ & 57,8 & 2,4 & 103,9 & 6,1 & 4,4 & 1507 & 75 \\
\hline & \multicolumn{7}{|c|}{ ano4: set/2002 a ago/2003 } \\
\hline tt & 43,4 & 1,3 & 25,8 & 4,8 & 2,3 & 1704 & 38 \\
\hline ad & 47,2 & 1,3 & 30,7 & 6,9 & 2,6 & 1490 & 45 \\
\hline $10+K P$ & 46,5 & 1,6 & 41,9 & 4,1 & 2,4 & 1565 & 53 \\
\hline $20+K$ & 49,6 & 1,7 & 57,2 & 4,2 & 2,7 & 1392 & 61 \\
\hline $40+K$ & 54,3 & 2,2 & 66,8 & 4,5 & 3,0 & 1202 & 71 \\
\hline
\end{tabular}


Observa-se que o efeito do biossólido sobre o aumento da quantidade de nutrientes retornada ao solo com a queda das folhas é considerável. As áreas onde foi aplicado biossólido, receberam sempre mais $\mathrm{N}, \mathrm{P}, \mathrm{Ca}, \mathrm{S}$ e Zn com a queda das folhas das árvores tratadas do que as parcelas testemunhas. No primeiro ano de coleta do folhedo, quando o efeito da aplicação de biossólido foi mais intenso, as árvores do tratamento "40+K" retornaram ao solo cinco vezes mais $\mathrm{Ca}$ e duas vezes mais $\mathrm{P}, \mathrm{S}$ e $\mathrm{Zn}$, duas vezes e meia mais $\mathrm{N}$ do que as testemunhas.

A análise estatística do efeito dos tratamentos sobre os conteúdos totais dos nutrientes analisados, tanto nas cascas quanto nos galhos, mostrou alterações não significativas para a maioria dos elementos. Distintas amplitudes de variação em torno das médias de cada tratamento foi comum para a maioria dos nutrientes, principalmente, no caso das cascas, levando à realização das transformações das variáveis respostas para se atingir a homocedasticidade.

Considerando o conteúdo de $\mathrm{N}$ nas cascas depositadas, foi necessária a utilização da variável transformada $Y=\log (\mathrm{N}+1)$ para realizar a análise, que detectou efeito significativo dos tratamentos ( $F=20,48 ; p<0,001)$. Na Figura 18 pode-se observar os maiores teores médios do conteúdo de $\mathrm{N}$ nas cascas que se soltaram dos eucaliptos que receberam biossólido, em relação às arvores testemunhas e que receberam adubação mineral. 


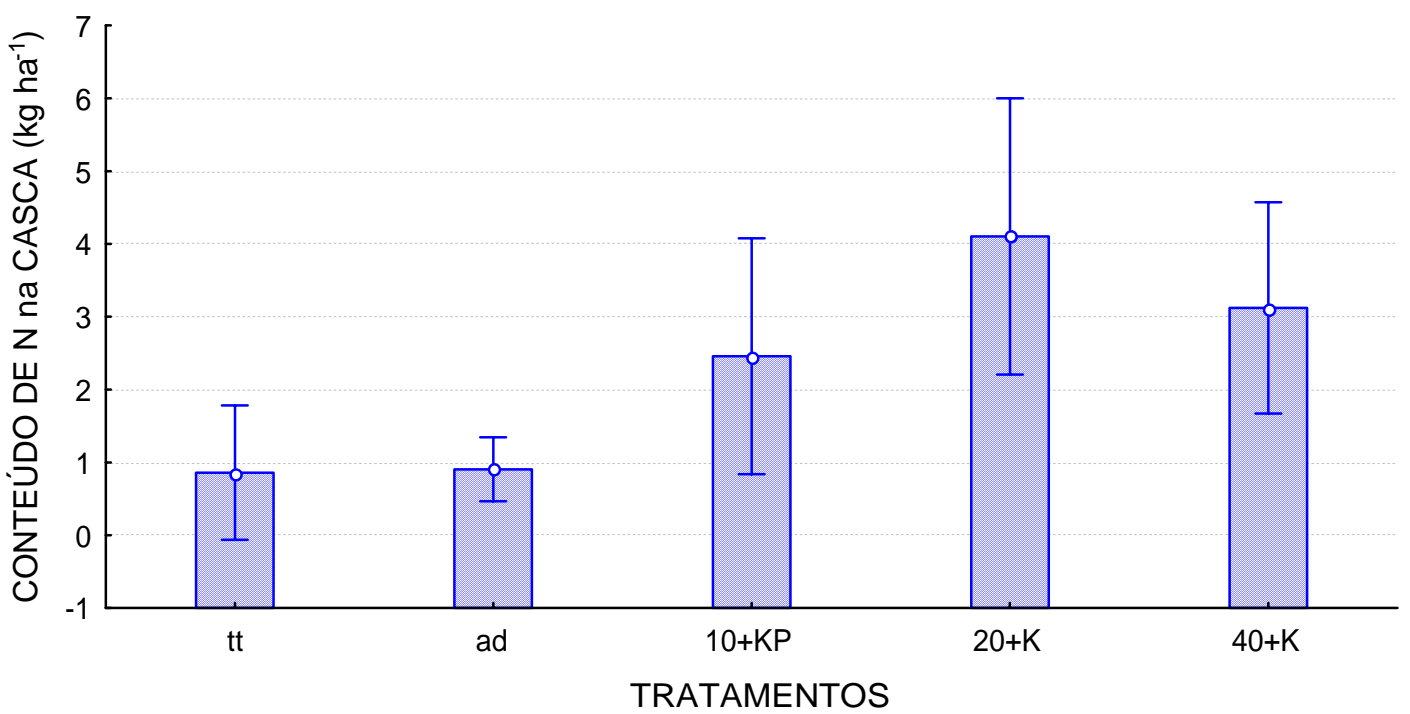

Figura 18- Variação no conteúdo total de $\mathbf{N}$ que retornou ao solo com a deposição de cascas pelos eucaliptos, durante os dois anos de coleta (09/2001 a 08/2003), em função dos tratamentos. São apresentados valores médios $(n=4)$ e os respectivos intervalos de confiança a 95\%

No caso do Ca nas cascas (Figura 19), a análise variável transformada $Y$ $=\log (\mathrm{Ca}+1)$ também mostrou efeito significativo dos tratamentos $(F=26,23$; $p<0,001)$. 


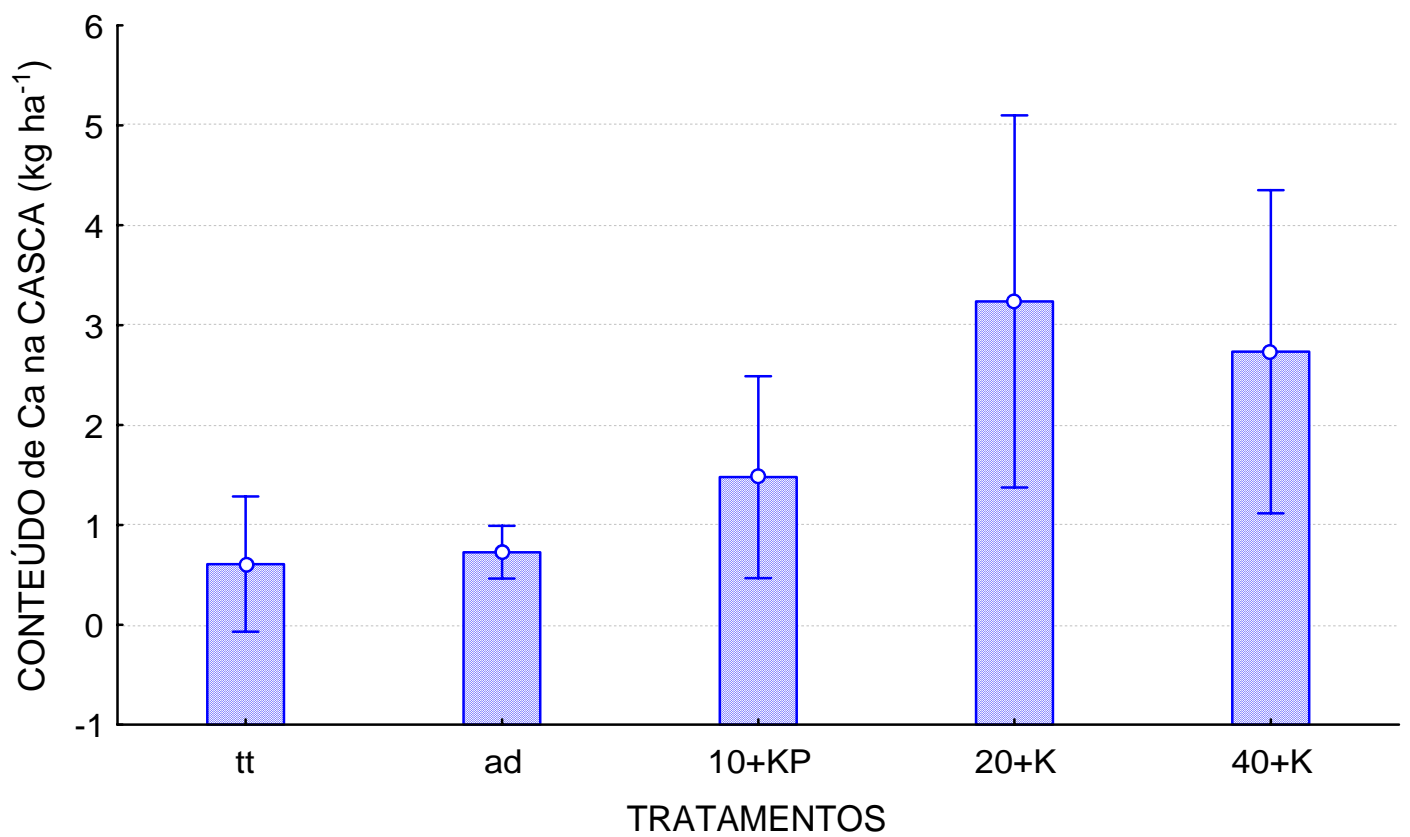

Figura 19- Variação no conteúdo total de $\mathbf{C a}$ que retornou ao solo com a deposição de cascas pelos eucaliptos, durante os dois anos de coleta (09/2001 a 08/2003), em função dos tratamentos. São apresentados valores médios $(n=4)$ e os respectivos intervalos de confiança a $95 \%$

No caso do Zn (Figura 20), a análise da variável transformada $Y=\log$ $(Z n+1)$, também mostra efeito significativo dos tratamentos $(F=53,85 ; p<0,001)$. 


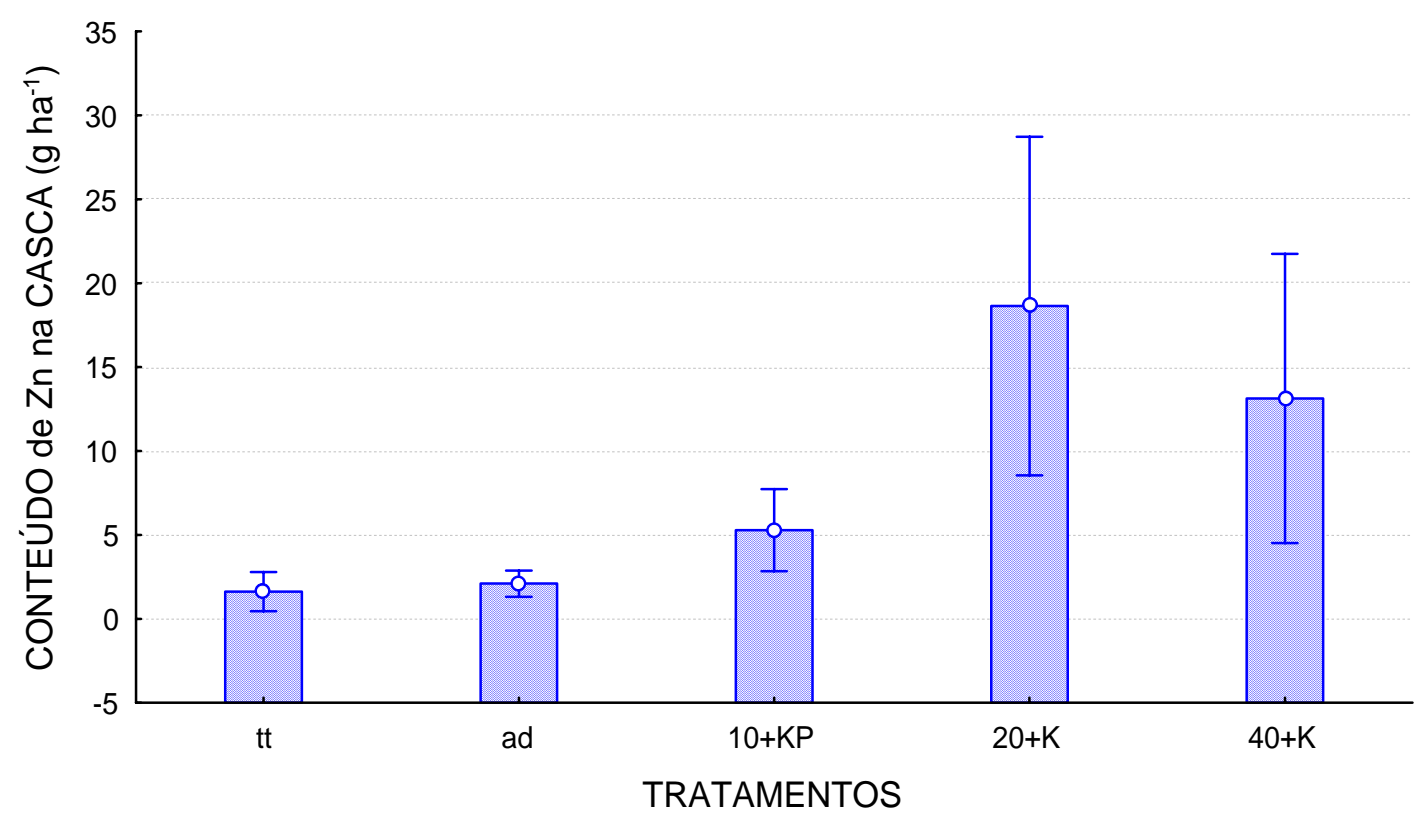

Figura 20- Variação no conteúdo total de Zn que retornou ao solo com a deposição de cascas pelos eucaliptos, durante os dois anos de coleta (09/2001 a 08/2003), em função dos tratamentos. São apresentados valores médios $(n=4)$ e os respectivos intervalos de confiança a $95 \%$

Pode ser observado nas Figuras 18, 19 e 20, que ocorreu o mesmo padrão de variação entre os tratamentos para os três nutrientes, cujos conteúdos totais nas cascas que se soltaram dos eucaliptos, durante dois anos de coleta, foram significativamente alterados. O tratamento "20+K", cujas árvores receberam a dose intermediária de biossólido, apresentou as maiores quantidades de N, Ca e $\mathrm{Zn}$ nas cascas senescentes. Os eucaliptos testemunhas e os eucaliptos que receberam adubação mineral apresentaram valores muito semelhantes entre si, valores esses menores do que os encontrados onde foi aplicado biossólido.

Considerando os galhos, apenas os conteúdos de Ca $(F=8,97 ; p=0,001)$ e $M n(F=3,96 ; p=0,028)$ foram significativamente afetados pelos tratamentos. 


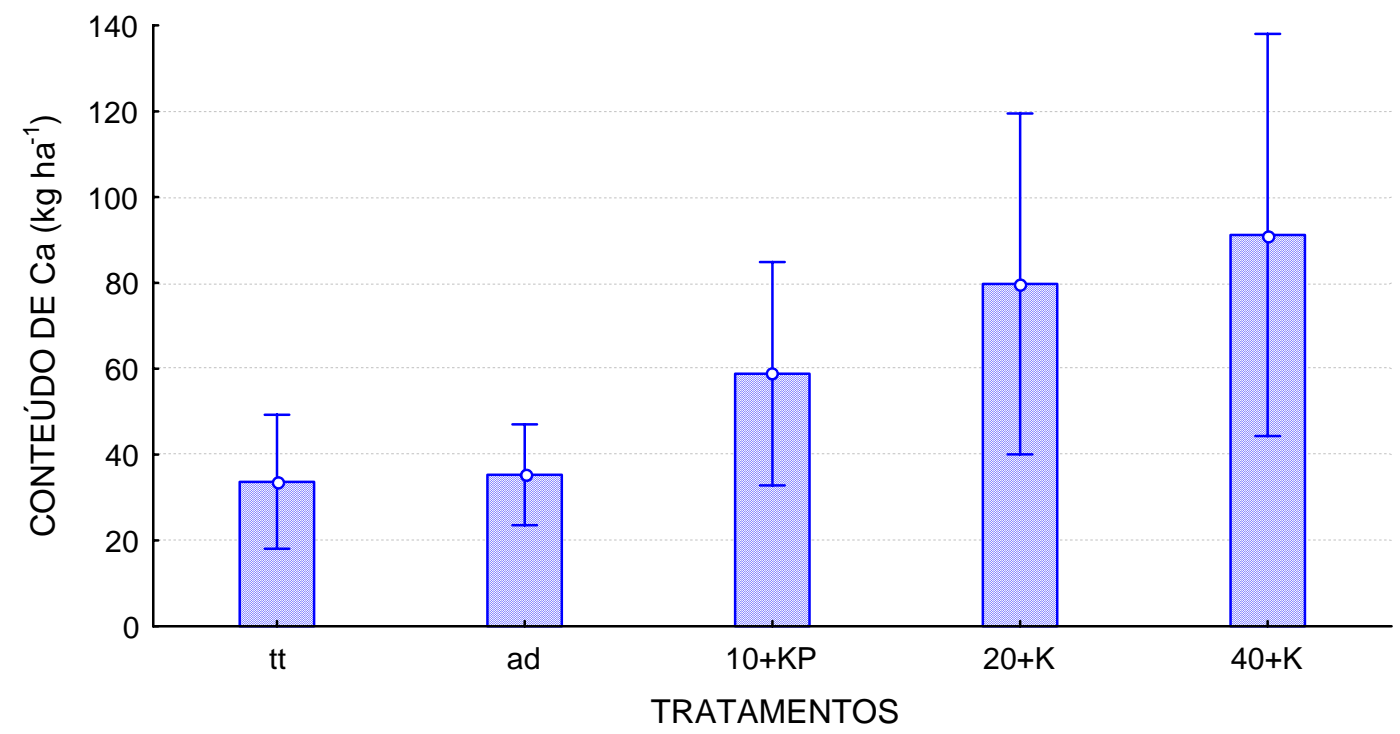

Figura 21- Variação no conteúdo total de Ca que retornou ao solo com a deposição de galhos pelos eucaliptos, durante os dois anos de coleta (09/2001 a 08/2003), em função dos tratamentos. São apresentados valores médios $(n=4)$ e os respectivos intervalos de confiança a $95 \%$

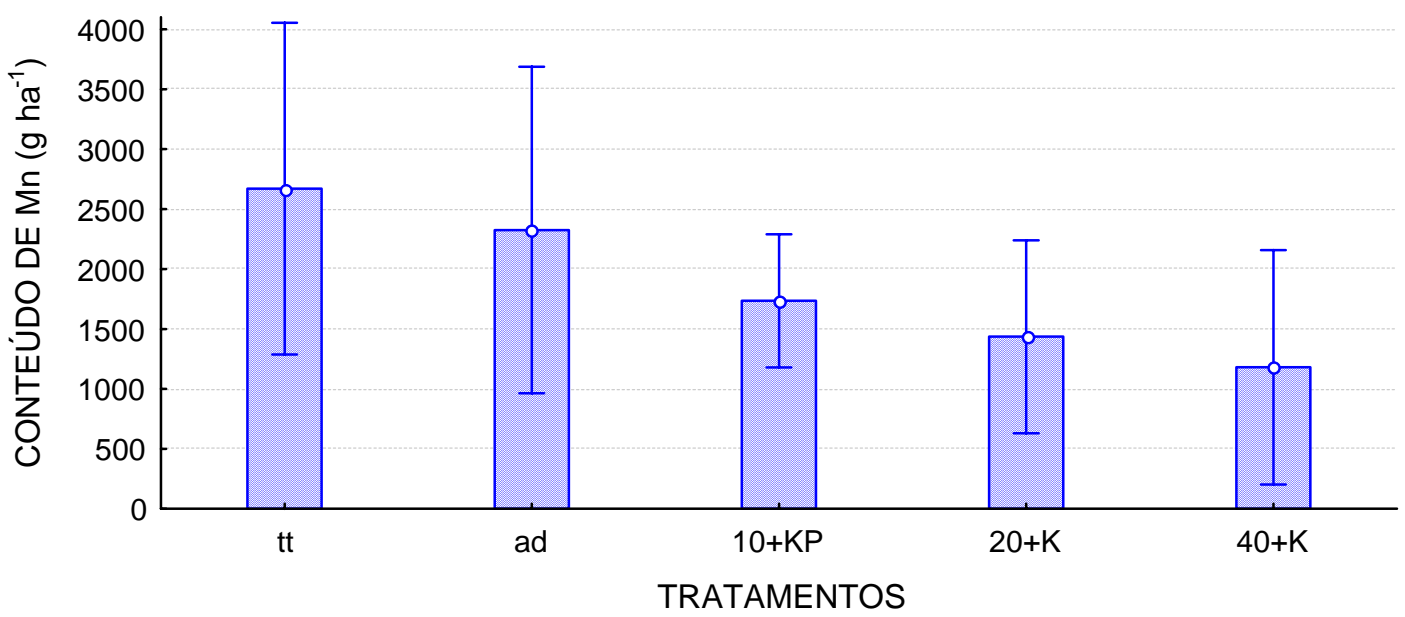

Figura 22. Variação no conteúdo total de Mn que retornou ao solo com a deposição de galhos pelos eucaliptos, durante os dois anos de coleta (09/2001 a 08/2003), em função dos tratamentos 
Os galhos depositados pelos eucaliptos que receberam biossólido apresentaram maior conteúdo de $\mathrm{Ca}$ do que os galhos dos eucaliptos testemunhas e que receberam adubação mineral. O padrão de diminuição dos teores de Mn com a aplicação de fertilização mineral e biossólido, também foi observado no caso dos galhos senescentes. 


\subsection{Degradação do biossólido e do folhedo de eucalipto}

$\mathrm{Na}$ Tabela 13 pode-se observar o total de massa seca de biossólido remanescente após cinco anos de aplicação e as porcentagens do resíduo remanescente e degradada. Considerando as duas texturas separadas na coleta, observa-se uma correlação positiva entre a relação grosso/fino (G/F) e as doses de biossólido, sendo que na maior dose (40 $\mathrm{Mg} \mathrm{ha}^{-1}$ ) aplicada, observou-se maior relação G/F e menor taxa de perda de massa. Isso é um indicativo de que, além das próprias características bioquímicas do biossólido, o efeito do tamanho das partículas e da área específica em contato com o solo, pode ser importante na taxa de saída de elementos inorgânicos do próprio biossólido e na determinação da taxa de decomposição do componente orgânico .

Tabela 13. Valores médios $(n=12)$ de massa seca (MS) do biossólido remanescente cinco anos após a aplicação, considerando as duas texturas (TX) separadas ou somadas. São apresentadas também as relações entre as frações grossa e fina (REL $G / F)$ e a porcentagem de massa de biossólido remanescente (REM) e degradada (DEG) para cada tratamento (TT)

\begin{tabular}{|c|c|c|c|c|c|c|}
\hline TT & TX & $\begin{array}{c}\text { MS } \\
---k g h^{-1}---\end{array}$ & REL G/F & $\begin{array}{r}\text { MST (G+F) } \\
---M g h^{-1}---\end{array}$ & REM & DEG \\
\hline $10+K P$ & G & 3824 & 2,7 & & & \\
\hline $10+K P$ & $F$ & 1420 & & 5,2 & 52 & 48 \\
\hline $20+K$ & G & 5931 & 3,0 & & & \\
\hline $20+K$ & $F$ & 2000 & & 7,9 & 40 & 60 \\
\hline $40+K$ & G & 18102 & 3,2 & & & \\
\hline $40+K$ & $F$ & 5649 & & 23,7 & 59 & 41 \\
\hline
\end{tabular}

G: $>2 \mathrm{~mm} ; \mathrm{F}:>1 \mathrm{e} \leq 2 \mathrm{~mm}$ 
Mesmo após o tempo de cinco anos em que o biossólido esteve esparramado no campo; em contato direto com o solo, com a serapilheira e com as raízes das plantas, submetido a todas as condições de intempéries e variações climáticas, o material apresentou taxa de perda de massa relativamente baixa, mostrando que o biossólido utilizado no experimento é um material de lenta decomposição. Apenas o biossólido que foi aplicado em uma dose de $20 \mathrm{Mg}$ $\mathrm{ha}^{-1}(20+\mathrm{K})$ diminuiu sua massa seca em mais de $50 \%$ ao final de cinco anos, chegando a taxa média maior do que $10 \%$ ao ano e igual a 2,42 $\mathrm{Mg} \mathrm{ha}^{-1} \mathrm{ano}^{-1}$. Esse resultado é semelhante ao encontrado por Robinson et al. (2002), que avaliaram, anualmente, durante cinco anos, a perda de massa de três tipos de biossólido aplicados superficialmente em uma plantação de Pinus Radiata na Austrália. Seus resultados mostraram taxas de degradação após cinco anos variando entre $52 \%$ e $67 \%$ da massa total dos biossólidos. Esses autores consideram a fração degradada como "pool" ativo e a massa remanescente sobre o solo após o período de cinco anos como inerte, caracterizando dois reservatórios de nutrientes distintos. Eles relatam que poucos estudos têm sido realizados, tanto em campo como em laboratório, sobre a perda de massa de biossólidos; sendo a maioria dos esforços focados sobre estudos das taxas de respiração durante experimentos de incubação com terra. Eles citam que encontraram na literatura apenas um artigo sobre perda de massa de biossólido aplicado superficialmente em condições de campo. Gilmour et al. (1996), avaliando o efeito de biossólido residual sobre a decomposição de biossólido fresco em experimento onde foram aplicadas, a cada duas ou quatro semanas, mais de $400 \mathrm{Mg} \mathrm{ha}^{-1}$ durante sete anos, encontraram que a taxa de decomposição de biossólido fresco foi independente de prévias adições e que a fração ativa mais lábil do biossólido residual representou de 6 a 10\% do carbono residual total. Riekerk (1981) também relatou que o biossólido apresenta lenta decomposição e baixas taxas de mineralização, especialmente, quando sob cobertura florestal. 
Andrade (2004), analisando os trabalhos realizados em condições controladas, cita vários autores que também encontraram resultados semelhantes aos seus, que mostram que parte do material orgânico contido no biossólido é recalcitrante e de difícil decomposição. A lenta decomposição do biossólido e conseqüente mineralização dos nutrientes pode ser interessante sob a perspectiva da reciclagem dos nutrientes, pois permite uma sincronia entre liberação e absorção dos elementos pelas árvores, diminuindo as saídas do ecossistema devido à lixiviação. Sob o ponto de vista do manejador, isso pode trazer problemas quando se necessita de uma rápida liberação de nutrientes, como é o caso do $\mathrm{P}$ para alimentar $\mathrm{o}$ arranque das mudas de eucalipto. Por outro lado, se torna interessante pela perspectiva de liberação de nutrientes durante todo o ciclo da cultura do eucalipto, inclusive durante uma segunda rotação.

Considerando apenas a fração orgânica, expressa como conteúdo de C, observou-se uma taxa de decomposição de 39\% em cinco anos nas parcelas onde foram aplicadas $10 \mathrm{Mg} \mathrm{ha}{ }^{-1}$ de biossólido (Tabela 14). Quando se aplicaram $20 \mathrm{Mg} \mathrm{ha}^{-1}$ a taxa foi de $60 \%$ e na dose de $40 \mathrm{Mg} \mathrm{ha}^{-1}$ foi de $64 \%$. $\mathrm{O}$ modelo de perda de material orgânico foi similar ao de massa total apenas para a dose de $20 \mathrm{Mg} \mathrm{ha}^{-1}$. Na dose de $10 \mathrm{Mg} \mathrm{ha}^{-1}$ a taxa de perda de massa foi $9 \%$ superior à taxa de decomposição, indicando que, proporcionalmente, perdeu-se mais elementos minerais do que C orgânico. Na dose de $40 \mathrm{Mg} \mathrm{ha}^{-1}$ a taxa de perda de massa foi 23\% menor do que a taxa de decomposição. Quando se aplicou a maior dose, formou-se uma camada mais espessa e com blocos maiores de biossólido, fato esse que pode ter dificultado a saída de elementos, principalmente o $\mathrm{Ca}$, que já se encontravam no próprio biossólido em sua forma mineral. Devido à adição de, aproximadamente, 30\% de Cal virgem durante o tratamento do esgoto na ETE de Barueri, o biossólido utilizado no experimento apresentou teor de $\mathrm{Ca}$ mineral de 9\%. Normalmente a saída direta de 
elementos inorgânicos do biossólido responde por grande proporção da perda de matéria (Robinson et al., 2002).

As características dos biossólidos influenciam diretamente em suas taxas de decomposição. Andrade (2004), citando vários autores, descreve que atributos químicos dos biossólidos, como valores excessivamente elevados de $\mathrm{pH}$, teores de metais pesados e sais solúveis conduzem a menores taxas de degradação dos resíduos. O teor de carbono do resíduo, embora apresente correlação positiva com a quantidade total de $\mathrm{CO}_{2}$ emanada a partir da misturas de amostras de solo e biossólidos pode correlacionar inversamente com a taxa de degradação. O autor chama a atenção para o fato de que valores de relação $\mathrm{C} / \mathrm{N}$ inferiores a 12, ao invés de indicar rápida degradação no solo, podem ser reflexo da predominância de uma MO parcialmente decomposta. Isso parece ser mais condizente para biossólidos, considerando-se a natureza dos mesmos. Esse autor realizou a caracterização química e estudou a decomposição, através da incubação em potes com terra e avaliação do $\mathrm{CO}_{2}$ evoluído, de cinco diferentes tipos de biossólidos, inclusive do biossólido tratado com cal produzido na ETE de Barueri, que foi utilizado nos trabalhos desta tese. Seus resultados permitem concluir que a matéria orgânica de biossólidos é predominantemente recalcitrante, com a fração facilmente biodegradável exaurida em poucos dias após aplicação no solo, tornando o restante do processo de decomposição do material relativamente mais lento, em comparação com a primeira fase.

Após cinco anos no campo, os conteúdos de nutrientes no biossólido remanescente são conseqüência do processo de decomposição e mineralização de sua carga orgânica, do balanço entre a lixiviação e a entrada de elementos em sua massa. Com a deposição de serapilheira sobre o biossólido foi se formando uma nova manta, cuja decomposição foi introduzindo novos elementos na massa do biossólido. Para todos os nutrientes, houve uma liberação líquida acima de 30\% do conteúdo inicial de nutrientes (Tabela 14). 
Tabela 14. Médias $(n=12)$ dos conteúdos de carbono orgânico e nutrientes no biossólido original e no biossólido remanescente nas parcelas de cada tratamento (TT) que receberam o resíduo, cinco anos após a aplicação. São apresentadas também as respectivas porcentagens de liberação dos nutrientes

\begin{tabular}{|c|c|c|c|c|c|c|c|c|}
\hline TT & C & $\mathbf{N}$ & $\begin{array}{c}\mathbf{P} \\
-k q a^{-1}\end{array}$ & $\mathrm{Ca}$ & $\mathbf{M g}$ & $\mathbf{S}$ & $\mathrm{Mn}$ & $\mathrm{Zn}$ \\
\hline \multirow{3}{*}{$10+K P$} & 1720 & 190 & 90 & 860 & 40 & 70 & 2680 & 16320 \\
\hline & 1046 & 76 & 39 & 401 & 12 & 12 & 2052 & 8066 \\
\hline & $\underline{39 \%}$ & $\underline{60 \%}$ & $\underline{57 \%}$ & $\underline{53 \%}$ & $70 \%$ & $\underline{83 \%}$ & $23 \%$ & $\underline{51 \%}$ \\
\hline \multirow{3}{*}{$20+K$} & 3440 & 380 & 180 & 1720 & 80 & 140 & 5360 & 32640 \\
\hline & 1360 & 75 & 60 & 636 & 15 & 16 & 1649 & 11073 \\
\hline & $\underline{60 \%}$ & $\underline{80 \%}$ & $\underline{67 \%}$ & $63 \%$ & $\underline{81 \%}$ & $\underline{89 \%}$ & $69 \%$ & $\underline{66 \%}$ \\
\hline \multirow{3}{*}{$40+K$} & 6880 & 760 & 360 & 3440 & 160 & 280 & 10720 & 65280 \\
\hline & 2502 & 182 & 137 & 1847 & 35 & 32 & 2907 & 25816 \\
\hline & $\underline{64 \%}$ & $\underline{76 \%}$ & $\underline{62 \%}$ & $\underline{46 \%}$ & $78 \%$ & $\underline{89 \%}$ & $73 \%$ & $\underline{60 \%}$ \\
\hline
\end{tabular}

Observa-se que, proporcionalmente, os nutrientes que foram mais liberados do biossólido foram S, N e Mg. O Ca apresentou maior liberação na dose de 20 Mg $\mathrm{ha}^{-1}$ e menor liberação na dose de $40 \mathrm{Mg} \mathrm{ha}^{-1}$, mostrando correlação com a taxa de perda de massa, que também foi maior nas parcelas do tratamento "20+K" e menor para o tratamento " $40+K$ ". Isso reforça a afirmação de que a lixiviação de Ca da massa do biossólido foi importante na determinação da taxa de degradação do resíduo.

Ao analisar a decomposição do folhedo produzido pelos eucaliptos, foi detectado pela análise de covariância que os tratamentos não influenciaram significativamente o efeito do tempo de decomposição sobre a fitomassa de folhedo remanescente $(F=0,4 ; p=0,820)$. Esse resultado coincide com $o$ de Prescott et al. (1993 b), que também não encontraram efeito da aplicação de biossólido sobre a quantidade de "litter" remanescente após dois anos de incubação e sobre a taxa de decomposição. Por outro lado, o efeito do tempo de decomposição foi altamente significativo $(F=173,1 ; p<0,001)$. Como não 
houve diferenças significativas entre tratamentos, todos os dados foram agrupados $(n=120)$ e analisados segundo o modelo exponencial negativo (Olson, 1963), independente de tratamento, gerando a seguinte equação para descrever a relação entre perda de massa de folhedo e o tempo de decomposição:

$$
\mathrm{Fr}=\mathrm{Fo} \times \mathrm{e}^{-0,03331 \mathrm{t}} \text {, onde }
$$

Fr é a massa remanescente de folhedo no tempo $t$;

Fo é a massa inicial de folhedo ( $5 \mathrm{~g})$;

t é o tempo decorrido em meses;

-0,03331 é a constante de decomposição (K) quando considerado o tempo em meses. Se for considerado o tempo em dias, o valor de K será de $-0,00110$, assim como para t em anos $\mathrm{K}=-0,3997$.

A representação gráfica dessa equação é mostrada na Figura 23, onde pode ser observado o processo de perda de fitomassa ao longo do tempo de decomposição de folhas senescentes de eucalipto. 


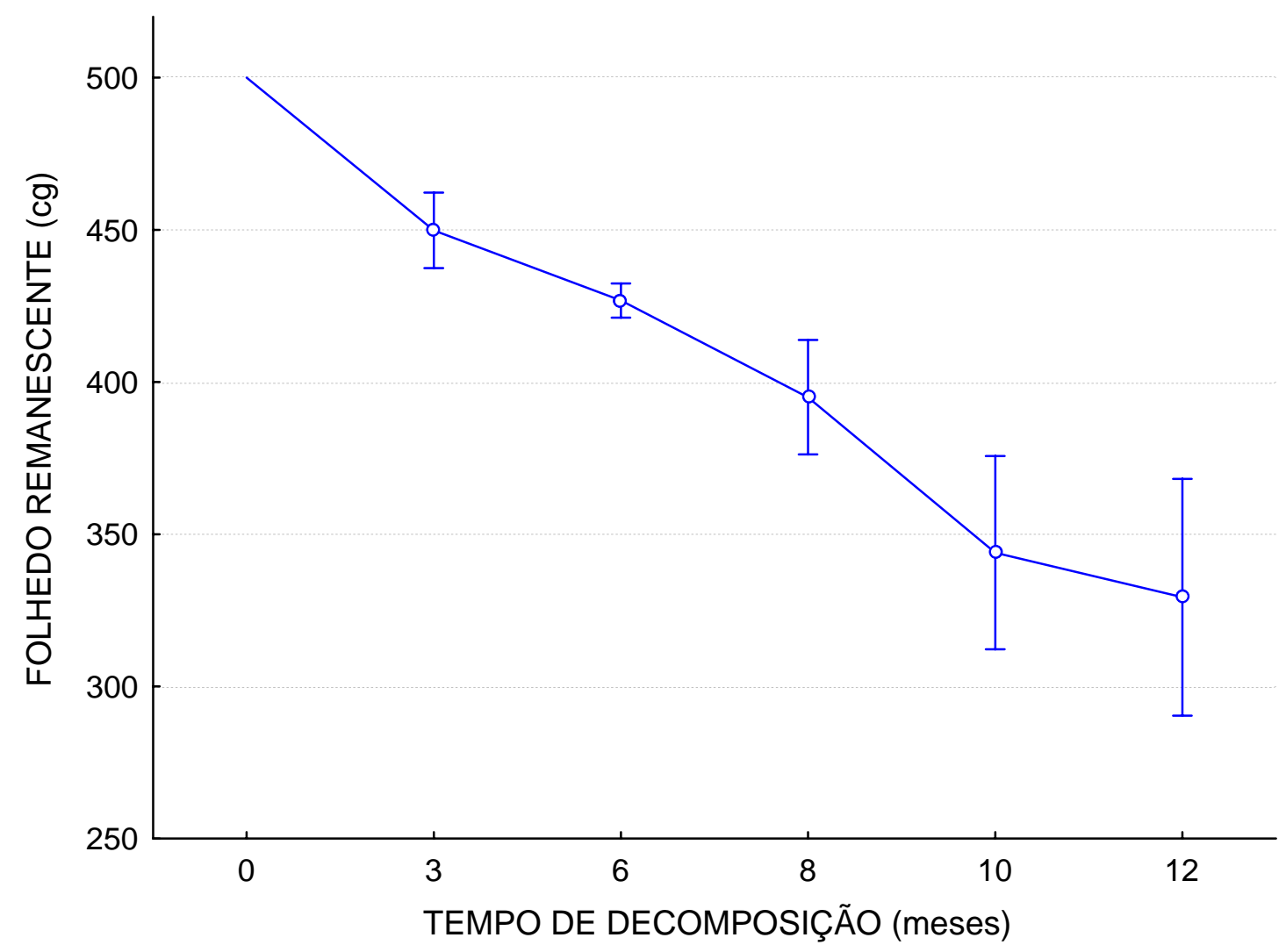

Figura 23- Avaliação da perda de massa durante um ano de decomposição de folhedo de Eucalyptus grandis, considerando a média de todos os tratamentos $(n=120)$. São apresentados os intervalos de confiança em torno das médias, construídos com 95\% de certeza

Após transcorrido o período de um ano, houve uma decomposição média de 26,4\% das folhas senescentes dos eucaliptos. Essa baixa taxa de perda de fitomassa do folhedo, assim como o valor da constante de decomposição $\left(K=-0,0331\right.$ mês $\left.^{-1}\right)$, indicam que o material analisado pode ser considerado de difícil decomposição. Foram também estimados coeficientes para a constante de decomposição considerando o tempo em dias $(K=-0,0011)$ e em anos $(K=-$ 0,3997). Lousada et al. (1997) apresentam valor de $K=-0,0024 \mathrm{dia}^{-1}$ para 
folhedo de um povoamento de eucalipto com várias espécies, durante sete meses de decomposição. O menor período de avaliação no trabalho citado pode ser um dos fatores utilizados para explicar o maior valor de K. Quanto menor o período de avaliação, apenas uma fração mais facilmente decomponível será degradada e não serão atingidos grupos mais recalcitrantes, o que levará a maior valor da constante.

O fato de que não foram observadas diferenças significativas, entre os tratamentos para a taxa de decomposição do folhedo, contraria a hipótese de que a aplicação de biossólido melhora a qualidade do material orgânico das folhas senescentes e aumenta sua velocidade de decomposição. Esse resultado é diferente do observado na fase inicial do experimento (Guedes, 2000), quando a aplicação de $40 \mathrm{Mg} \mathrm{ha}^{-1}$ de biossólido aumentou em 29\% a taxa de decomposição do folhedo, em relação ao tratamento testemunha. No período em que foi realizado o experimento de decomposição que determinou os resultados apresentados nesta tese (06/2002 a 06/2003), o efeito dos tratamentos sobre a deposição de folhedo foi menor do que na fase inicial do experimento (Figura 5), assim como diminuiu também o efeito sobre o conteúdo de nutrientes que retornou ao solo (Tabela 16). Pode ser que, no caso da decomposição do folhedo, essa variável também tenha seguido um modelo de maior efeito dos tratamentos logo após a aplicação, com a diminuição da resposta ao longo do tempo.

A análise dos componentes estruturais da matéria orgânica, pela técnica de Ressonância Magnética Nuclear, confirma que os tratamentos não afetaram a qualidade do C orgânico (Tabela 15) presente no folhedo colocado para decompor e produzido pelos eucaliptos nos meses de janeiro e fevereiro de 2002, três anos e meio após a aplicação do biossólido. 
Tabela 15. Caracterização inicial das estruturas de $C$ presente no folhedo de eucalipto, produzido e colocado para decompor em cada tratamento (TT). São apresentadas as intensidades relativas de estruturas de $\mathrm{C}$, de acordo com as integrais das áreas geradas pelos espectros oriundos da análise de ressonância magnética nuclear do ${ }^{13} \mathrm{C}$

\begin{tabular}{ccccccccc}
\hline & Alquil & Metoxil & O-alquil & $\begin{array}{c}\text { Aromá } \\
\text { tico }\end{array}$ & $\begin{array}{c}\text { Fenó } \\
\text { lico }\end{array}$ & \multicolumn{2}{c}{ Carboxil Carbonil } & $\begin{array}{c}\text { total } \\
\text { arom }\end{array}$ \\
$\mathbf{T T}$ & $\mathbf{0 - 4 5}$ & $45-60$ & $60-110$ & $110-140$ & $140-160$ & $160-185$ & $185-230$ & $110-160$ \\
\hline $\mathbf{t t}$ & 0,34 & 0,09 & 0,41 & 0,07 & 0,04 & 0,04 & 0,01 & 0,11 \\
$\mathbf{a d}$ & 0,33 & 0,09 & 0,44 & 0,06 & 0,04 & 0,04 & 0,01 & 0,10 \\
$\mathbf{1 0 + K P}$ & 0,34 & 0,09 & 0,42 & 0,07 & 0,04 & 0,04 & 0,01 & 0,11 \\
$\mathbf{2 0 + K}$ & 0,34 & 0,09 & 0,41 & 0,07 & 0,04 & 0,05 & 0,01 & 0,11 \\
$\mathbf{4 0 + K}$ & 0,33 & 0,09 & 0,42 & 0,07 & 0,04 & 0,04 & 0,01 & 0,11 \\
\hline
\end{tabular}

Observa-se que não há diferenças entre tratamentos para nenhuma das frações de $\mathrm{C}$ analisadas no folhedo que foi colocado para decompor. Apesar da aplicação de biossólido alterar a dinâmica nutricional dos eucaliptos e os teores dos nutrientes no solo, além de alterar a própria liberação e imobilização de nutrientes no folhedo em decomposição, o processo de perda de massa dependeria mais da estrutura do $\mathrm{C}$ do que do conteúdo dos outros nutrientes. Assim, considerando o fator qualidade do material, a forma do C na estrutura bioquímica dos compostos deve ser o fator mais determinante da decomposição. De acordo com Ostertag \& Hobbie (1999), a falta de resposta do processo de decomposição após fertilização pode ocorrer porquê os microorganismos são limitados primariamente por fontes de carbono apropriadas, mais do que pelos teores de $\mathrm{N}$ ou $\mathrm{P}$.

A Figura 23 ilustra a caracterização dos componentes da matéria orgânica do folhedo de eucalipto, mostrando um espectro resultante da análise através da Ressonância Magnética Nuclear do ${ }^{13} \mathrm{C}$ de uma amostra do folhedo produzido pelos eucaliptos testemunhas. A maior parte da intensidade observada na região do C O-alquil (60 a 110 ppm) pode ser atribuída ao pico 
observado em 75 ppm. Segundo Preston et al. (1997) e Almendros et al. (2000), que estudaram a decomposição de vários tipos de serapilheira de diferentes espécies, foi freqüente a associação desse pico com os biopolímeros celulose e hemicelulose, sendo a holocelulose também encontrada com sinal intenso em 63 ppm. Nessa região há também a contribuição de biopolímeros como a lignina (picos em 56 e 72 ppm). Na região do C tipo alquil (0 a 45 ppm), o pico ocorre em 30 ppm, sendo normalmente associado a lipídeos e polímeros de lipídeos como cutinas e ceras.

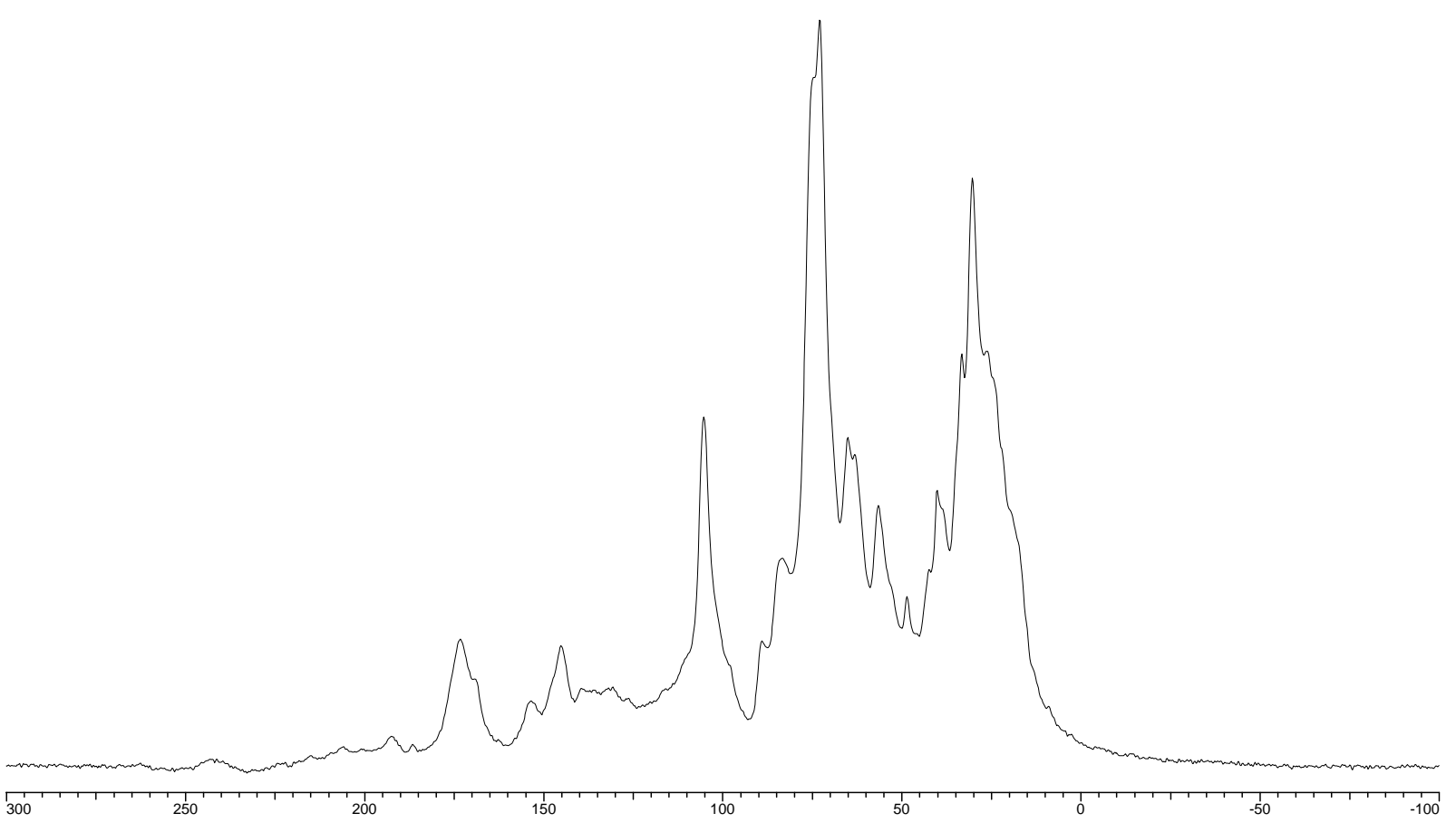

Figura 23- Espectro da análise de ressonância magnética nuclear do ${ }^{13} \mathrm{C}$ do folhedo produzido pelas árvores de Eucalyptus grandis nas parcelas testemunhas que não receberam nenhum tratamento

Apesar de não se verificar efeito dos tratamentos sobre a taxa de decomposição e sobre as estruturas de C presentes no folhedo, verificou-se alterações no processo de mineralização e imobilização de nutrientes. A Tabela 16 mostra as diferenças entre os tratamentos para os conteúdos de nutrientes 
no folhedo remanescente durante o processo de decomposição, expressos como porcentagens dos conteúdos iniciais nos tecidos do folhedo de cada tratamento no início do experimento.

Tabela 16. Diferenças entre as quantidades iniciais de nutrientes presentes em $5 \mathrm{~g}$ de folhedo colocados para decompor em cada tratamento (TT) e as quantidades de nutrientes na fitomassa remanescente após um ano de decomposição. São apresentadas também as porcentagens de nutrientes perdidos ou acumulados (valores negativos) durante $o$ período, em relação às quantidades iniciais de nutrientes

\begin{tabular}{cccccccc}
\hline $\mathbf{T T}$ & $\mathbf{N}$ & $\mathbf{P}$ & $\mathbf{C a}$ & $\begin{array}{c}\mathbf{M g} \\
\mathrm{mg} \mathrm{e} \%\end{array}$ & $\mathbf{S}$ & $\mathbf{M n}$ & $\mathbf{Z n}$ \\
\hline $\mathbf{t t}$ & $-4,19$ & 0,36 & 3,89 & 3,85 & 0,34 & 1,25 & $-0,05$ \\
$\mathbf{t t}$ & $\underline{-9 \%}$ & $\underline{24 \%}$ & $\underline{12 \%}$ & $\underline{63 \%}$ & $\underline{11 \%}$ & $\underline{46 \%}$ & $\underline{-108 \%}$ \\
$\mathbf{a d}$ & $-8,80$ & 0,80 & 15,03 & 5,05 & 0,88 & 1,09 & $-0,05$ \\
$\mathbf{a d}$ & $\underline{-20 \%}$ & $\underline{53 \%}$ & $\underline{41 \%}$ & $\underline{67 \%}$ & $\underline{33 \%}$ & $\underline{55 \%}$ & $\underline{-99 \%}$ \\
$\mathbf{1 0 + K P}$ & 5,61 & 0,79 & 2,93 & 2,57 & 1,10 & 0,76 & $-0,10$ \\
$\mathbf{1 0 + K P}$ & $\underline{11 \%}$ & $\underline{42 \%}$ & $\underline{5 \%}$ & $\underline{59 \%}$ & $\underline{30 \%}$ & $\underline{41 \%}$ & $\underline{-182 \%}$ \\
$\mathbf{2 0 + K}$ & 2,69 & 0,49 & 26,17 & 3,11 & 2,64 & 0,99 & $-0,12$ \\
$\mathbf{2 0 + K}$ & $\underline{5 \%}$ & $\underline{26 \%}$ & $\underline{28 \%}$ & $\underline{69 \%}$ & $\underline{60 \%}$ & $\underline{56 \%}$ & $\underline{-173 \%}$ \\
$\mathbf{4 0 + K}$ & 11,85 & 0,70 & 16,80 & 3,28 & 2,82 & 0,77 & $-0,09$ \\
$\mathbf{4 0 + K}$ & $\underline{\mathbf{2 1} \%}$ & $\underline{\mathbf{2 9} \%}$ & $\underline{16 \%}$ & $\underline{71 \%}$ & $\underline{63 \%}$ & $\underline{57 \%}$ & $\underline{-112 \%}$ \\
\hline
\end{tabular}

Observa-se que os nutrientes que apresentaram acúmulo líquido foram o Zn e o N. Mesmo após um ano de degradação do folhedo, com uma taxa média de decomposição de $26,4 \%$, a menor fitomassa presente no final do processo acumulou maiores conteúdos desses nutrientes do que os conteúdos presentes nos $5 \mathrm{~g}$ colocados para decompor. Esse acúmulo de nutrientes normalmente reflete ganhos pela imobilização na biomassa microbiana, pela fixação de $\mathrm{N}$ ou 
pela deposição atmosférica (Ostertag \& Hobbie, 1999). O Zn apresentou elevadas taxas de acúmulo no folhedo incubado nas parcelas de todos os tratamentos. O N apresentou acúmulo líquido apenas nos tratamentos testemunha e adubação mineral, que não receberam biossólido, indicando que a aplicação do resíduo acelera o processo de mineralização e de liberação do N. Como o folhedo produzido pelos eucaliptos que receberam biossólido apresentou maiores teores iniciais de $\mathrm{N}$, sua decomposição pode ter propiciado a lixiviação inicial de N. Segundo Prescott et al. (1993 a), somente tipos de "litter" particularmente ricos em $\mathrm{N}$ apresentam uma fase inicial de lixiviação e o ganho ou perda líquida de $\mathrm{N}$ vai depender de sua concentração original no material colocado para decompor. Esses autores observaram aumentos na concentração e no conteúdo de $\mathrm{N}$ em vários tipos de "litter" até o segundo ano de decomposição. Stevenson (1982) também relata que é esperado o aumento da concentração de N com o tempo de decomposição.

Os nutrientes $\mathrm{P}, \mathrm{Ca}, \mathrm{Mg}, \mathrm{S}$ e $\mathrm{Mn}$ apresentaram sempre taxas líquidas positivas, indicando mineralização e liberação desses elementos. Nas parcelas do tratamento adubação mineral (ad) houve maior liberação de P e Ca do que nas parcelas dos outros tratamentos. Nas parcelas do tratamento " $40+K$ ", onde foi aplicada a maior dose de biossólido, houve maior liberação de $\mathrm{N}$ e $\mathrm{S}$. Considerando a média dos tratamentos, a ordem de liberação dos elementos foi a seguinte: $\mathrm{Mg}>\mathrm{Mn}>\mathrm{S}>\mathrm{P}>\mathrm{Ca}$, com $\mathrm{N}$ e $\mathrm{Zn}$ apresentando variados graus de acúmulo líquido. Nas parcelas do tratamento "40+K" verificou-se a seguinte ordem de liberação: $\mathrm{Mg}>\mathrm{S}>\mathrm{Mn}>\mathrm{P}>\mathrm{N}>\mathrm{Ca}$, sendo que apenas o $\mathrm{Zn}$ apresentou acúmulo líquido.

Bubb et al. (1998) citam vários autores que observaram que a transição da fase de imobilização de $\mathrm{N}$ em serapilheira sob florestas para a fase de mineralização e liberação líquida coincide com uma relação $\mathrm{C} / \mathrm{N}$ crítica variando entre 24 e 30 . Os autores explicaram a ausência de mineralização de $\mathrm{N}$ em seu trabalho com serapilheira de Araucaria pela relação $\mathrm{C} / \mathrm{N}$ igual a 37,6 no final do 
processo de decomposição. Esses mesmos autores chamam a atenção para o fato de que a composição bioquímica não representa o processo de decomposição, e que indicadores baseados na composição bioquímica são muito simplistas e que é necessário desenvolver melhores tecnologias para estudar a decomposição da serapilheira e a associada dinâmica de nutrientes.

Os resultados das análises aproximadas sobre a composição bioquímica do folhedo (Tabela 17) mostram que sua qualidade varia entre tratamentos, tanto no material intacto colhido nos coletores e colocado para decompor, quanto ao longo do processo de decomposição. 
Tabela 17. Composição bioquímica do folhedo produzido pelos eucaliptos em diferentes tratamentos (TT), considerando três tempos de decomposição (TD). São apresentados os teores, em \% de material seco, obtidos durante realização de "análises aproximadas"

\begin{tabular}{|c|c|c|c|c|c|c|c|c|}
\hline TT & $\begin{array}{c}\text { TD } \\
\text { meses }\end{array}$ & ET & LR & HOLO & CINZAS & FENOIS & C & $\mathbf{N}$ \\
\hline tt & 0 & 42,23 & 43,88 & 13,89 & 2,19 & 8,25 & 51,9 & 0,97 \\
\hline tt & até 6 & 37,46 & 46,32 & 16,22 & 2,48 & 7,82 & 47,78 & 1,02 \\
\hline tt & 6 a 12 & 31,36 & 47,70 & 20,94 & 3,38 & 4,28 & 44,63 & 1,23 \\
\hline ad & 0 & 42,40 & 45,47 & 12,13 & 2,43 & 9,43 & 48,75 & 0,90 \\
\hline ad & até 6 & 38,36 & 44,55 & 17,10 & 2,64 & 6,82 & 48,53 & 0,97 \\
\hline ad & 6 a 12 & 31,60 & 47,15 & 21,25 & 3,53 & 3,86 & 48 & 1,21 \\
\hline $10+K P$ & 0 & 40,50 & 44,53 & 14,97 & 3,22 & 9,34 & 48,9 & 1,01 \\
\hline $10+K P$ & até 6 & 34,80 & 44,50 & 20,71 & 3,22 & 6,58 & 45,9 & 1,05 \\
\hline $10+K P$ & 6 a 12 & 29,49 & 47,95 & 22,56 & 5,05 & 3,39 & 46,05 & 1,38 \\
\hline $20+K$ & 0 & 39,36 & 41,83 & 18,81 & 5,00 & 7,53 & 47,4 & 1,06 \\
\hline $20+K$ & até 6 & 35,79 & 41,15 & 23,06 & 4,63 & 6,99 & 43,43 & 0,98 \\
\hline $20+K$ & 6 a 12 & 29,13 & 49,88 & 20,99 & 6,41 & 3,11 & 44,25 & 1,38 \\
\hline $40+K$ & 0 & 35,93 & 39,25 & 24,82 & 5,73 & 5,22 & 49,9 & 1,14 \\
\hline $40+K$ & até 6 & 34,95 & 40,92 & 24,13 & 4,79 & 6,29 & 40,95 & 0,98 \\
\hline $40+K$ & 6 a 12 & 28,71 & 46,67 & 24,63 & 6,96 & 3,44 & 44,85 & 1,40 \\
\hline
\end{tabular}

Considerando a média dos tempos de decomposição, a aplicação da maior dose de biossólido (tratamento $40+K$ ) alterou a composição bioquímica do folhedo em relação ao tratamento testemunha, diminuindo em cerca de $10 \%$ os teores de extrativos totais e lignina, em $27 \%$ o teor de compostos fenólicos, e aumentando em $44 \%$ o teor de holocelulose e em 117\% a concentração de cinzas. 
As proporções de vários elementos nas cinzas da matéria seca são características para certas espécies e famílias de plantas, bem como para certos organismos e estádios de desenvolvimento (Larsher, 1995). Segundo esse autor, plantas crescendo sobre solos particularmente pobres em nutrientes e ácidos, apresentam baixo conteúdo de cinzas (1 a 3\% da matéria seca).

Considerando a média dos tratamentos, a variação ao longo do processo de decomposição mostra que houve diminuição nos teores de extrativos, de carbono orgânico e de fenóis; e aumento nos teores de lignina, holocelulose, cinzas e N. A relação lignina/C aumentou de 0,87 para 0,96 e para 1,05 durante o processo de decomposição, indicando que primeiro é degradado o C mais lábil de compostos como fenóis e de compostos extraídos em água e álcool (extrativos totais), que diminuíram seus teores com o tempo de decomposição. Por outro lado, no C remanescente vai aumentando a participação e os teores de grupos mais recalcitrantes como os componentes da lignina. $\mathrm{Na}$ Tabela 18 pode-se observar as correlações entre as variáveis envolvidas no processo de decomposição, considerando as amostras coletas nas parcelas dos cinco tratamentos e o tempo de decomposição dividido em três períodos (inicial folhedo intacto; médio - folhedo remanescente coletado aos três e aos seis meses; final - folhedo remanescente coletado aos oito, dez e doze meses). 
Tabela 18. Coeficientes de correlação $(n=15)$ entre as doses de biossólido (DB), o tempo de decomposição (TD), a massa de folhedo perdida durante a decomposição (FP), teores de biopolímeros* determinados por "análises aproximadas", teores de cinzas e conteúdo de nutrientes remanescentes em folhedo de Eucalyptus grandis durante um ano de decomposição. Valores em negrito foram significativos em nível de $1 \%$ de probabilidade

\begin{tabular}{|c|c|c|c|c|c|c|c|c|c|}
\hline & DB & TD & $\mathbf{N}$ & $\mathbf{P}$ & $\mathrm{Ca}$ & Mg & S & Mn & $\mathrm{Zn}$ \\
\hline DB & 1,00 & 0,00 & 0,43 & 0,52 & 0,95 & $-0,34$ & 0,30 & $-0,56$ & 0,47 \\
\hline TD & 0,00 & 1,00 & $-0,22$ & $-0,64$ & $-0,08$ & $-0,84$ & $-0,68$ & $-0,76$ & 0,69 \\
\hline FP & 0,00 & 0,99 & $-0,20$ & $-0,61$ & $-0,08$ & $-0,84$ & $-0,66$ & $-0,75$ & 0,68 \\
\hline ET & $-0,33$ & $-0,91$ & $-0,12$ & 0,30 & $-0,27$ & 0,91 & 0,52 & 0,89 & $-0,84$ \\
\hline LR & $-0,47$ & 0,69 & $-0,13$ & $-0,50$ & $-0,48$ & $-0,39$ & $-0,77$ & $-0,27$ & 0,41 \\
\hline HOLO & 0,72 & 0,54 & 0,23 & 0,02 & 0,66 & $-0,76$ & $-0,03$ & $-0,83$ & 0,67 \\
\hline CINZAS & 0,83 & 0,38 & 0,54 & 0,32 & 0,85 & $-0,61$ & $-0,08$ & $-0,77$ & 0,79 \\
\hline FENOIS & $-0,32$ & $-0,85$ & $-0,23$ & 0,24 & $-0,25$ & 0,80 & 0,55 & 0,82 & $-0,78$ \\
\hline $\mathrm{C} / \mathrm{N}$ & $-0,41$ & $-0,84$ & $-0,26$ & 0,15 & $-0,38$ & 0,91 & 0,44 & 0,87 & $-0,87$ \\
\hline lig/N & $-0,59$ & $-0,55$ & $-0,61$ & $-0,21$ & $-0,57$ & 0,73 & 0,18 & 0,73 & $-0,75$ \\
\hline $\begin{array}{c}\text { lig/ } \\
(\operatorname{lig}+E T)\end{array}$ & 0,05 & 0,95 & 0,04 & $-0,42$ & 0,00 & $-0,82$ & $-0,70$ & $-0,76$ & 0,79 \\
\hline $\begin{array}{c}\text { ligl } \\
\text { (lig+hol) }\end{array}$ & $-0,78$ & $-0,30$ & $-0,24$ & $-0,15$ & $-0,73$ & 0,60 & $-0,21$ & 0,68 & $-0,48$ \\
\hline
\end{tabular}

*ET (extrativos totais), LR (lignina residual), HOLO (holocelulose)

Observando as correlações na Tabela 18, confirmam-se os resultados obtidos para as taxas de decomposição, os quais mostraram que a aplicação de biossólido não influenciou a taxa de perda de massa do folhedo. As doses de biossólido (DB) não apresentaram correlação com o tempo de decomposição (TD), nem com a fitomassa de folhedo perdida durante a decomposição. Por outro lado, apresentaram correlação positiva com os teores de holocelulose e cinzas e negativa com a relação entre lignina/(lignina+holocelulose). O aumento do teor de cinzas, que representa o conteúdo mineral, no folhedo com o aumento da quantidade de biossólido aplicada está fortemente associado ao 
aumento do teor de $\mathrm{Ca}$, que também apresenta elevada correlação $(r=0,85)$ com as doses de biossólido, devido ao alto teor desse nutriente encontrado no resíduo. Há um forte efeito do tempo de decomposição sobre a fitomassa de folhedo perdida durante o processo, sendo que ao longo da degradação há uma diminuição nos teores de extrativos totais, compostos fenólicos e da relação $\mathrm{C} / \mathrm{N}$, e aumento nos teores de lignina residual e da relação entre lignina/(lignina+extrativos). Em relação ao conteúdo de nutrientes verifica-se correlação negativa com o Mg, Mn, S e P, e correlação positiva com o Zn, com o aumento do tempo de decomposição (TD) e da fitomasssa perdida de folhedo (FP).

Considerando as relações, independente dos tratamentos, entre os biopolímeros e o conteúdo de nutrientes durante o processo de decomposição, verifica-se que a mineralização e liberação dos nutrientes que foram mais liberados (Mg e Mn), apresentaram melhores correlações com os teores de Extrativos Totais (ET); assim como, verifica-se maior correlação negativa entre os Extrativos e o conteúdo de Zn. A diminuição dos extrativos ao longo da decomposição é fortemente associada com a liberação de $\mathrm{Mg}$ e $\mathrm{Mn}$ e com o acúmulo de $\mathrm{Zn}$. 


\subsection{Estoque de nutrientes nos compartimentos do ecossistema}

\subsubsection{Fitomassa epígea dos eucaliptos}

$\mathrm{Na}$ Figura 23 pode-se observar o acúmulo de volume comercial de madeira durante o desenvolvimento dos eucaliptos até os cinco anos de idade, considerando o efeito dos diversos tratamentos.

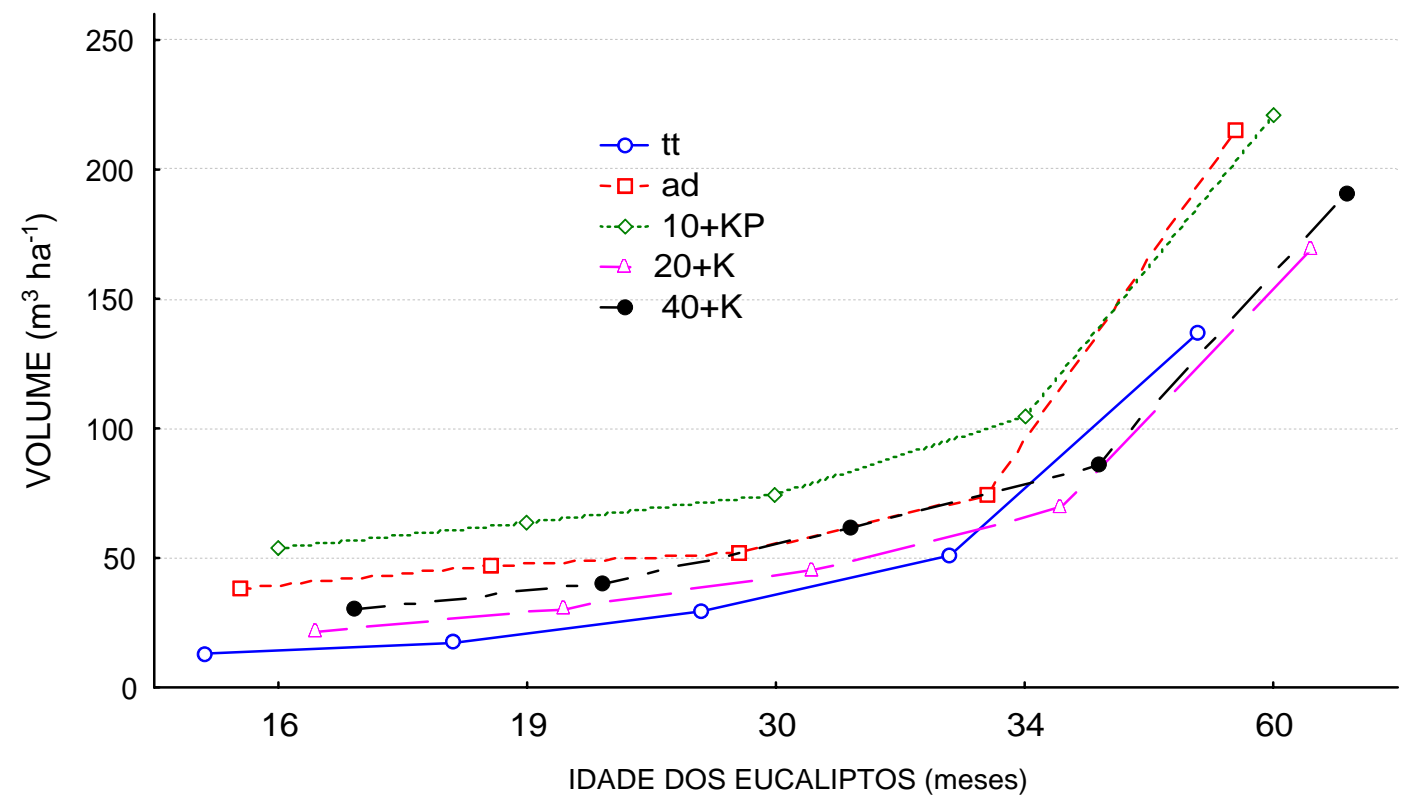

Figura 23- Efeito dos tratamentos sobre a produção de volume comercial de madeira de Eucalyptus grandis ao longo da rotação.

tt (testemunha), ad (adubação mineral), 10+KP (10 $\mathrm{Mg} \mathrm{ha}^{-1}$ de biossólido complementadas com K e P mineral), 20+K (20 Mg ha ${ }^{-1}$ de biossólido complementadas com $\mathrm{K}$ mineral), 40+K (40 $\mathrm{Mg} \mathrm{ha}^{-1}$ de biossólido complementadas com $\mathrm{K}$ mineral)

Os eucaliptos que receberam $10 \mathrm{Mg} \mathrm{ha}^{-1}$ de biossólido mais fósforo mineral aplicado durante o plantio $(10+K P)$ apresentaram, durante todo o período analisado, o melhor desenvolvimento e maior produção de madeira comercial. Até, aproximadamente, três anos de idade (Jan-01), as diferenças em relação 
aos outros tratamentos foram significativamente maiores, considerando os intervalos de confiança de 95\%. Polglase \& Myers (1995) relatam incremento de 64 e $61 \mathrm{~m}^{3} \mathrm{ha}^{-1}$ de volume de madeira para duas procedências de E. grandis irrigadas com efluente de ETE na Austrália, até os 34 meses de idade. Pode-se observar na Figura 23 que esses valores estão próximos aos encontrados nesta tese para os tratamentos mais produtivos aos 34 meses, "10+KP" e "40+K". Do terceiro para o quinto ano (Feb-03) houve maior desenvolvimento dos eucaliptos que receberam adubação mineral e a diferença em relação ao tratamento "10+KP" deixou de ser significativa. Após cinco anos de crescimento, o efeito dos tratamentos sobre a produção volumétrica dos eucaliptos refletiu na seguinte ordem de importância dos tratamentos para a produção comercial de madeira: "10+KP"="ad" > "40+K"="20+K" > "tt". Essa ordem de importância dos tratamentos para a produção de volume de madeira comercial foi confirmada pele análise da fitomassa acumulada nos troncos (lenhos + cascas) das árvores (Tabela 19). Nessa tabela pode-se observar também a fitomassa para os outros componentes e o total de fitomassa arbórea acima do solo. 
Tabela 19. Variação na média $(n=4)$ de fitomassa seca dos componentes de árvores de Eucalyptus grandis, cinco anos após o plantio, em função dos tratamentos (TT). São apresentadas também, as porcentagens que cada componente representa em relação à fitomassa total

\begin{tabular}{|c|c|c|c|c|c|}
\hline & lenho & casca & galho & folha & total \\
\hline TT & ----------- & --------י & $\mathrm{Mg} \mathrm{ha}^{-1}$ & & \\
\hline tt & 51,3 & 6,9 & 5,0 & 4,3 & 67,5 \\
\hline ad & 81,6 & 10,3 & 7,8 & 6,1 & 105,9 \\
\hline $10+K P$ & 84,1 & 10,8 & 8,1 & 6,3 & 109,3 \\
\hline $20+K$ & 63,8 & 8,0 & 5,9 & 4,8 & 82,7 \\
\hline $40+K$ & 72,3 & 9,5 & 6,9 & 5,5 & 94,3 \\
\hline tt & 76,0 & 10,2 & 7,4 & 6,4 & 100 \\
\hline ad & 77,1 & 9,7 & 7,4 & 5,8 & 100 \\
\hline $10+K P$ & 76,9 & 9,9 & 7,4 & 5,8 & 100 \\
\hline $20+K$ & 77,1 & 9,7 & 7,1 & 5,8 & 100 \\
\hline $40+K$ & 76,7 & 10,1 & 7,3 & 5,8 & 100 \\
\hline
\end{tabular}

*tt (testemunha), ad (adubação mineral), 10+KP $\left(10 \mathrm{Mg} \mathrm{ha}^{-1}\right.$ de biossólido complementadas com $\mathrm{K}$ e $\mathrm{P}$ mineral), $20+\mathrm{K}$ (20 Mg ha ${ }^{-1}$ de biossólido complementadas com K mineral), 40+K (40 Mg ha-1 de biossólido complementadas com $\mathrm{K}$ mineral)

Os eucaliptos do tratamento "10+KP" apresentaram mais fitomassa acumulada em todos os componentes, o que resultou em $62 \%$ a mais de fitomassa total acima do solo nessas árvores em relação às testemunhas. Esse fato está coerente com as observações dendrométricas realizadas ao longo da rotação, que sempre mostraram maior incremento em volume para os eucaliptos do tratamento "10+KP". A aplicação de biossólido e de fertilizantes não alterou a partição da fitomassa total dos eucaliptos entre os componentes, sendo que, as porcentagens que cada componente representa do total são equivalentes para todos os tratamentos. A classificação dos componentes dos 
eucaliptos em relação à fitomassa acumulada aos cinco anos de idade não foi afetada pelos tratamentos e gerou a seguinte seqüência: lenho $\gg$ > casca > galho > folha. Para os eucaliptos do tratamento "10+KP", que apresentaram maior produtividade, a fitomassa total de tronco (lenho + casca) acumulada em cinco anos foi de $94,9 \mathrm{Mg} \mathrm{ha}^{-1}$, o que resultou em um incremento médio anual (IMA) de $19 \mathrm{Mg} \mathrm{ha}^{-1} \mathrm{ano}^{-1}$ de madeira com casca. Esses valores estão coerentes com os apresentados por Santana et al. (1999), para E. grandis com 6,5 anos em cinco sítios no interior do estado de São Paulo. Esses autores avaliaram três procedências diferentes e encontraram valores variando de 95 a $206 \mathrm{Mg} \mathrm{ha}^{-1}$ de matéria seca de tronco. Laclau et al. (2000) mostraram valores de $65 \mathrm{Mg} \mathrm{ha}^{-1}$ para a fitomassa da parte aérea de um clone de um híbrido do gênero Eucalyptus plantado no Congo. Poggiani (1985) encontrou $186 \mathrm{Mg} \mathrm{ha}^{-1}$ de fitomassa aérea de $E$. saligna com 14 anos. Guo et al. (2002), encontraram para $E$. globulus de três anos de idade irrigado com efluente de frigorífico, valor de $72 \mathrm{Mg} \mathrm{ha}^{-1}$.

Em termos de produtividade primária líquida (fitomassa epígea acumulada aos cinco anos mais o que foi contabilizado da deposição de serapilheira) da parte aérea dos eucaliptos, as árvores do tratamento "10+KP" também apresentaram maior incremento do que todos os outros tratamentos. Esses eucaliptos produziram $136 \mathrm{Mg} \mathrm{ha}^{-1}$ de matéria seca, 34\% a mais do que as árvores testemunhas, que produziram $90 \mathrm{Mg} \mathrm{ha}^{-1}$. Esse valor está subestimado e não é a produtividade primária líquida total, pois não foram contabilizados o folhedo produzido até 1,5 ano e as cascas e galhos produzidos até os 3,5 anos. Segundo Laclau (2003), esses valores podem chegar a 2,3 Mg $\mathrm{ha}^{-1}$ para o folhedo e 1,3 $\mathrm{Mg} \mathrm{ha}^{-1}$ para cascas e galhos.

Analisando o desenvolvimento da cultura até os cinco anos, verifica-se que, tanto em termos de produção de madeira, quanto em termos de produtividade primária líquida, a aplicação de $10 \mathrm{Mg} \mathrm{ha}^{-1}$ de biossólido mais, apenas $P$ mineral na época do plantio, foi suficiente para que os eucaliptos 
produzissem, em média, mais matéria seca do que os eucaliptos que receberam adubação mineral completa. Isso mostra que a aplicação de biossólido é capaz de suprir as exigências nutricionais para o desenvolvimento dos eucaliptos, no que se refere a todos os outros nutrientes ( $\mathrm{N}, \mathrm{Ca}, \mathrm{Mg}, \mathrm{B}$ e $\mathrm{Zn}$ ) que foram colocados com a adubação mineral e que, no tratamento "10+KP", foram provenientes apenas do biossólido. Isso mostra também que o excesso de Ca adicionado através do biossólido não afetou o crescimento dos eucaliptos.

A Tabela 20 mostra os teores dos nutrientes analisados na matéria seca dos quatro componentes das árvores, para cada tratamento testado. 
Tabela 20. Valores médios $(n=4)$ dos teores de nutrientes em componentes (COMPO) de árvores de Eucalyptus grandis abatidas nas parcelas de cada tratamento (TT), cinco anos após o plantio

\begin{tabular}{|c|c|c|c|c|c|c|c|c|}
\hline \multirow{2}{*}{ COMPO } & \multirow[b]{2}{*}{ TT } & $\mathbf{N}$ & $\mathbf{P}$ & $\mathrm{Ca}$ & Mg & S & \multirow{2}{*}{\multicolumn{2}{|c|}{ Mn $\quad$ Zn }} \\
\hline & & --- & $--\cdot-\cdot$ & $-\mathrm{g} \mathrm{kg}^{-}$ & & - & & \\
\hline \multirow{5}{*}{ lenho } & tt & 3,9 & 0,1 & 0,2 & 0,1 & $<0,01$ & 30 & 5 \\
\hline & ad & 5,0 & 0,1 & 0,4 & 0,1 & $<0,01$ & 18 & 3 \\
\hline & $10+K P$ & 5,2 & 0,2 & 0,7 & 0,1 & $<0,01$ & 14 & 4 \\
\hline & $20+K$ & 5,9 & 0,2 & 0,8 & 0,1 & $<0,01$ & 8 & 5 \\
\hline & $40+K$ & 5,3 & 0,2 & 0,8 & 0,1 & $<0,01$ & 4 & 4 \\
\hline \multirow{5}{*}{ casca } & tt & 5,4 & 0,2 & 3,7 & 1,3 & 0,2 & 385 & 8 \\
\hline & ad & 5,2 & 0,3 & 4,4 & 1,7 & 0,2 & 247 & 8 \\
\hline & $10+K P$ & 6,7 & 0,5 & 7,8 & 1,2 & 0,2 & 223 & 11 \\
\hline & $20+K$ & 6,5 & 0,5 & 9,2 & 1,4 & 0,2 & 173 & 12 \\
\hline & $40+K$ & 5,9 & 0,5 & 12,3 & 1,4 & 0,2 & 99 & 9 \\
\hline \multirow{5}{*}{ galho } & tt & 7,8 & 0,2 & 2,2 & 0,5 & 0,3 & 469 & 13 \\
\hline & ad & 6,7 & 0,3 & 2,5 & 0,9 & 0,3 & 347 & 13 \\
\hline & $10+K P$ & 6,3 & 0,3 & 5,2 & 0,5 & 0,3 & 275 & 18 \\
\hline & $20+K$ & 9,3 & 0,4 & 8,9 & 0,6 & 0,3 & 221 & 21 \\
\hline & $40+K$ & 8,2 & 0,3 & 8,9 & 0,6 & 0,2 & 164 & 21 \\
\hline \multirow{5}{*}{ folha } & tt & 22,6 & 1,1 & 4,2 & 2,1 & 0,8 & 623 & 21 \\
\hline & ad & 22,1 & 1,1 & 4,4 & 2,5 & 0,8 & 336 & 19 \\
\hline & $10+K P$ & 22,9 & 1,3 & 8,5 & 1,5 & 0,7 & 368 & 23 \\
\hline & $20+K$ & 25,9 & 1,4 & 12,6 & 1,6 & 0,8 & 300 & 30 \\
\hline & $40+K$ & 24,8 & 1,3 & 13,8 & 1,6 & 0,7 & 192 & 28 \\
\hline
\end{tabular}

Verifica-se que, mesmo nos eucaliptos com cinco anos de idade, os teores de Ca são mais elevados e os de Mg são inferiores nas árvores dos tratamentos que receberam biossólido, confirmando a afirmação de que a aplicação de biossólido alcalino aumenta a relação $\mathrm{Ca} / \mathrm{Mg}$, provavelmente devido à competição por sítios de absorção entre esses dois elementos (Guedes \& Poggiani, 2003). Um nítido padrão de diminuição dos teores de $\mathrm{Mn}$ nos eucaliptos que receberam adubação mineral e biossólido, observado na fase inicial do experimento e relatado no trabalho citado anteriormente, também se 
mantém até os cinco anos de idade. Também são observados aumentos nos teores de $\mathrm{N}$ e $\mathrm{P}$, em todos os componentes, dos eucaliptos que receberam biossólido.

A comparação entre teores de nutrientes em componentes de árvores, apresentados em diferentes trabalhos, deve ser realizada com cautela. É preciso estar atento ao analisar teores foliares de nutrientes e consciente de que existem fatores que não estão ligados ao desenvolvimento da planta que podem alterar esses teores. O adequado balanceamento dos nutrientes depende do antagonismo ou sinergismo na relação entre os elementos, e essas relações podem ser alteradas para diferentes espécies e condições locais, tanto quando ambos os nutrientes estão em níveis ótimos, excessivos ou deficientes. De acordo com Silveira et al. (2000), o ataque de pragas e doenças, aplicação indevida de defensivos, utilização de conceitos de diluição e concentração de nutrientes, material genético e condições ambientais são fatores que podem alterar os teores de nutrientes nas plantas. Isso pode levar a resultados contraditórios quando se analisa a relação entre o desenvolvimento das plantas e a concentração de nutrientes em seus componentes.

Considerando o gênero Eucalyptus, vários estudos pesquisaram a relação de variáveis respostas que representam o desenvolvimento das árvores ( $\mathrm{H}$, DAP, volume, fitomassa) com os teores dos nutrientes nos componentes dos eucaliptos, encontrando os mais distintos resultados. Sgarby (2002), na revisão de literatura de sua dissertação sobre efeito dos nutrientes na produtividade de Eucalyptus, cita vários trabalhos que relatam as seguintes relações entre o desenvolvimento de espécies de Eucalyptus e os teores foliares dos nutrientes: correlação negativa da altura de $E$. grandis aos 2,5 anos de idade com $\mathrm{Mg}, \mathrm{K}$ e Ca; correlação positiva da altura de $E$. saligna aos 8 anos com os teores de $\mathrm{P}, \mathrm{K}, \mathrm{Mg}, \mathrm{Ca}$ e N; correlação negativa da altura de $E$. grandis aos 3 anos com os teores de Ca e B e positiva com os teores de N, P, K, Mg e S; correlação positiva do índice de sítio plantado com E. grandis de 20 anos 
com N e P nas folhas; correlação negativa da altura e DAP de E. camaldulensis com B e positiva com $\mathrm{Mn}$ e $\mathrm{Cu}$; correlação negativa da produtividade em volume de E. grandis com um ano de idade com Mn e positiva com Ca e N; correlação positiva da produtividade de E. grandis e E. urophyla com $\mathrm{Ca}, \mathrm{Mg} \mathrm{e}$ B e negativa com Mn, correlação positiva da produtividade de E. grandis com B, Cu e Fe e negativa com Ca, Mn e Zn.

Segundo Marschner (1995), a distribuição e acúmulo dos nutrientes na árvore dependem da concentração e da função de cada nutriente nos vários tecidos e órgãos e principalmente da biomassa do compartimento. O equilíbrio dos nutrientes minerais e o balanço de carbono na vegetação são fortemente interdependentes. A captura de nutrientes minerais controla o aumento na fitomassa e a assimilação de carbono torna disponível a matéria na qual os elementos são incorporados. Por exemplo, a energia e a estrutura molecular requerida para incorporação de $\mathrm{N}$ são derivadas do metabolismo do $\mathrm{C}$, que por causa de sua dependência da fotossíntese, também depende de compostos contendo N como a Clorofila (Larcher, 1995). Por outro lado, o incremento em produtividade pode não se correlacionar com o conteúdo de alguns nutrientes. Por exemplo, Santana et al. (1999) avaliaram diferentes materiais genéticos de Eucalyptus com 6,5 anos de idade, em diferentes locais do estado de São Paulo e encontraram para alguns sítios, relações entre o conteúdo de $\mathrm{K}$ no tronco e a produção de biomassa de tronco, cerca de três vezes mais elevadas do que em outros sítios. No entanto, isso não se refletiu na produtividade, sugerindo um "consumo de luxo" de K pelo eucalipto.

Multiplicando-se a fitomassa de cada componente pelos respectivos teores de nutrientes, estimou-se a mineralomassa estocada em cada componente das árvores (Tabela 21). 
Tabela 21. Valores médios $(n=4)$ do conteúdo de nutrientes nos componentes (Compo) de Eucalyptus grandis, cinco anos após o plantio, em função dos tratamentos (TT)

\begin{tabular}{|c|c|c|c|c|c|c|c|c|}
\hline \multirow[t]{2}{*}{$T T$} & \multirow[t]{2}{*}{ Compo } & $\mathbf{N}$ & $\mathbf{P}$ & $\mathrm{Ca}$ & Mg & S & $M n$ & $Z n$ \\
\hline & & \multicolumn{7}{|c|}{ - } \\
\hline \multirow{5}{*}{ tt } & lenho & 203 & 4 & 12 & 5 & 0 & 1,505 & 0,251 \\
\hline & casca & 37 & 1 & 24 & 8 & 2 & 2,553 & 0,058 \\
\hline & galho & 39 & 1 & 10 & 3 & 1 & 2,303 & 0,067 \\
\hline & folha & 104 & 6 & 32 & 8 & 4 & 1,705 & 0,102 \\
\hline & total & $\underline{383}$ & 12 & $\underline{78}$ & $\underline{24}$ & $\underline{6}$ & 8,067 & $\underline{0,478}$ \\
\hline \multirow{5}{*}{ ad } & lenho & 403 & 8 & 28 & 10 & 0 & 1,425 & 0,260 \\
\hline & casca & 54 & 3 & 45 & 17 & 2 & 2,537 & 0,076 \\
\hline & galho & 52 & 2 & 20 & 7 & 2 & 2,809 & 0,103 \\
\hline & folha & 145 & 8 & 46 & 11 & 4 & 2,192 & 0,138 \\
\hline & total & 653 & $\underline{21}$ & $\underline{139}$ & $\underline{46}$ & $\underline{8}$ & 8,962 & $\underline{0,576}$ \\
\hline \multirow{5}{*}{$10+K P$} & lenho & 444 & 12 & 56 & 8 & 0 & 1,199 & 0,351 \\
\hline & casca & 73 & 5 & 84 & 13 & 2 & 2,488 & 0,113 \\
\hline & galho & 51 & 2 & 42 & 4 & 2 & 2,294 & 0,146 \\
\hline & folha & 152 & 8 & 53 & 13 & 5 & 2,563 & 0,155 \\
\hline & total & $\underline{721}$ & $\underline{27}$ & $\underline{235}$ & $\underline{38}$ & 10 & 8,544 & $\underline{0,765}$ \\
\hline \multirow{5}{*}{$20+K$} & lenho & 375 & 9 & 51 & 6 & 0 & 0,517 & 0,298 \\
\hline & casca & 52 & 4 & 75 & 11 & 2 & 1,429 & 0,100 \\
\hline & galho & 56 & 2 & 52 & 3 & 2 & 1,283 & 0,123 \\
\hline & folha & 113 & 6 & 50 & 8 & 4 & 1,546 & 0,134 \\
\hline & total & 596 & $\underline{21}$ & $\underline{228}$ & $\underline{29}$ & $\underline{7}$ & 4,775 & $\underline{0,654}$ \\
\hline \multirow{5}{*}{$40+K$} & lenho & 380 & 11 & 54 & 7 & 0 & 0,255 & 0,258 \\
\hline & casca & 56 & 5 & 115 & 13 & 2 & 0,927 & 0,088 \\
\hline & galho & 55 & 2 & 61 & 4 & 1 & 1,130 & 0,143 \\
\hline & folha & 129 & 7 & 54 & 10 & 4 & 1,730 & 0,119 \\
\hline & total & 621 & 24 & 284 & 33 & $\underline{8}$ & 4,043 & $\underline{0,609}$ \\
\hline
\end{tabular}

O tratamento "10+KP", que apresentou maior acúmulo de fitomassa para todos os componentes, apresenta também maior mineralomassa de N, P, S e Zn. Na maioria das vezes, há uma estreita relação entre produção de biomassa 
e conteúdo de nutrientes nas árvores, conforme pode ser observado em Santana et al. (1999). Esses autores encontraram que os conteúdos da maioria dos nutrientes no tronco do eucalipto foram maiores nos sítios mais produtivos e nos materiais genéticos melhor adaptados. Por outro lado, o tratamento "10+KP" apresenta menores valores de mineralomassa de Ca do que os eucaliptos dos tratamentos " $20+K$ " e "40+K", que apresentaram elevados teores de Ca em todos os componentes, e menor mineralomassa de $\mathrm{Mg}$ do que os eucaliptos que receberam adubação mineral e apresentaram maiores teores de Mg. Em todos os tratamentos, considerando os componentes lenho e folha, a quantidade de nutrientes imobilizados na fitomassa acompanhou a seguinte ordem: $\mathrm{N}>\mathrm{Ca}>\mathrm{Mg}>\mathrm{P}>\mathrm{S}$. Para o componente galho, houve alteração nessa seqüência para os dois últimos macronutrientes, sendo que $S>P$ no tratamento "40+K" e S = P nos demais tratamentos. Considerando o componente casca, houve inversão nos dois primeiros elementos, sendo $\mathrm{Ca}>\mathrm{N}$ apenas nos tratamentos que receberam biossólido. Gonçalves et al. (2000) apresenta a seguinte ordem dos nutrientes mais acumulados no tronco: $\mathrm{Ca}>\mathrm{N}>\mathrm{K}>\mathrm{Mg}>$ P.

Os valores apresentados nesta tese, de maneira geral, estão condizentes com os resultados de trabalhos da literatura. Os conteúdos de $\mathrm{N}$, que variaram de 383 a $621 \mathrm{~kg} \mathrm{ha}^{-1}$, e de Ca, que variaram de 78 a $284 \mathrm{~kg} \mathrm{ha}^{-1}$, englobam os relatados por Gonçalves \& Barros (1999), que analisaram dados de dezessete povoamentos de $E$. grandis com idade média de 5,6 anos: $392 \mathrm{~kg} \mathrm{ha}^{-1}$ de N e $256 \mathrm{~kg} \mathrm{ha}^{-1}$ de $\mathrm{Ca}$. No caso do $\mathrm{P}$, os valores encontrados nesta tese, $12 \mathrm{a} 27 \mathrm{~kg}$ $\mathrm{ha}^{-1}$, são inferiores aos $34 \mathrm{~kg} \mathrm{ha}^{-1}$ do trabalho de Gonçalves \& Barros (1999).

A seguir pode ser observado o efeito dos tratamentos sobre a razão entre os componentes tronco / copa, para os conteúdos de nutrientes imobilizados nos eucaliptos (Tabela 22). 
Tabela 22. Efeito dos tratamentos sobre a razão entre os conteúdos de nutrientes imobilizados no tronco (lenho + casca) em relação à copa (folhas + galhos) das árvores de E. grandis aos cinco anos de idade

\begin{tabular}{cccccccc}
\hline $\mathbf{T T}$ & $\mathbf{N}$ & $\mathbf{P}$ & $\mathbf{C a}$ & $\mathbf{M g}$ & $\mathbf{S}$ & $\mathbf{M n}$ & $\mathbf{Z n}$ \\
\hline $\mathbf{t t}$ & 1,7 & 0,9 & 0,8 & 1,3 & 0,3 & 1,0 & 1,8 \\
$\mathbf{a d}$ & 2,3 & 1,1 & 1,1 & 1,5 & 0,4 & 0,8 & 1,4 \\
$\mathbf{1 0 + K P}$ & 2,5 & 1,7 & 1,5 & 1,2 & 0,3 & 0,8 & 1,5 \\
$\mathbf{2 0 + K}$ & 2,5 & 1,7 & 1,2 & 1,5 & 0,3 & 0,7 & 1,5 \\
$\mathbf{4 0 + K}$ & 2,4 & 1,8 & 1,5 & 1,5 & 0,4 & 0,4 & 1,3 \\
\hline
\end{tabular}

A aplicação de biossólido propiciou o aumento das razões entre os componentes tronco / copa, para os conteúdos de N, P e Ca. Isso indica que, proporcionalmente, pode ter havido maior imobilização, até os cinco anos de idade, desses nutrientes para a formação de madeira e tronco em relação às copas, nos eucaliptos que receberam biossólido. Para os micronutrientes $\mathrm{Mn}$ e Zn, houve uma diminuição da relação tronco / copa com a aplicação dos tratamentos, em relação aos eucaliptos testemunhas.

A tabela 23 mostra a influência dos tratamentos, em termos relativos, sobre a partição dos conteúdos de nutrientes entre todos os componentes da fitomassa epígea dos eucaliptos. De maneira geral, considerando a média de todos os tratamentos, o componente lenho acumulou mais N (60\%), Zn (46\%) e P (42\%); o componente casca acumulou mais Ca (34\%) e Mg (37\%); as folhas das copas acumularam mais S (53\%) e Mn (30\%). Analisando a participação percentual de cada componente na constituição da mineralomassa dos eucaliptos em cada tratamento, verifica-se que a variação na relação tronco / copa, mostrada anteriormente (Tabela 22), quando se aplicou biossólido, se deve mais ao componente folha. Os eucaliptos testemunhas apresentaram, proporcionalmente em relação aos outros componentes, maior acúmulo de $\mathrm{N}$, 
$\mathrm{P}, \mathrm{Ca}, \mathrm{Mg}$ e $\mathrm{S}$, e menor percentual de $\mathrm{Mn}$ acumulado nas folhas do que os eucaliptos que receberam tratamento. Esse fato propiciou uma menor relação tronco/copa para a maioria dos nutrientes e uma maior relação para os micronutrientes nos eucaliptos testemunhas.

Tabela 23. Efeito dos tratamentos sobre as porcentagens de conteúdos de nutrientes imobilizados em cada compartimento aéreo (comp) das árvores de E. grandis aos cinco anos de idade

\begin{tabular}{|c|c|c|c|c|c|c|c|c|}
\hline \multirow[b]{2}{*}{ TT } & \multirow[b]{2}{*}{ comp } & $\mathbf{N}$ & $\mathbf{P}$ & $\mathrm{Ca}$ & Mg & $\mathbf{S}$ & Mn & Zn \\
\hline & & \multicolumn{7}{|c|}{ 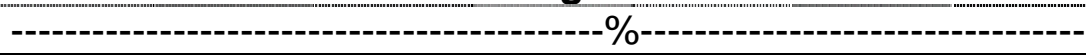 } \\
\hline \multirow{5}{*}{ tt } & lenho & 53 & 36 & 15 & 21 & 0 & 19 & 52 \\
\hline & casca & 10 & 10 & 31 & 35 & 24 & 32 & 12 \\
\hline & galho & 10 & 6 & 13 & 11 & 19 & 29 & 14 \\
\hline & folha & 27 & 48 & 41 & 33 & 56 & 21 & 21 \\
\hline & total & 100 & 100 & 100 & 100 & 100 & 100 & 100 \\
\hline \multirow{5}{*}{ ad } & lenho & 62 & 40 & 20 & 22 & 0 & 16 & 45 \\
\hline & casca & 8 & 14 & 33 & 38 & 27 & 28 & 13 \\
\hline & galho & 8 & 10 & 14 & 15 & 23 & 31 & 18 \\
\hline & folha & 22 & 36 & 33 & 25 & 50 & 24 & 24 \\
\hline & total & 100 & 100 & 100 & 100 & 100 & 100 & 100 \\
\hline \multirow{5}{*}{$10+K P$} & lenho & 62 & 45 & 24 & 22 & 0 & 14 & 46 \\
\hline & casca & 10 & 18 & 36 & 34 & 26 & 29 & 15 \\
\hline & galho & 7 & 8 & 18 & 10 & 22 & 27 & 19 \\
\hline & folha & 21 & 29 & 23 & 34 & 52 & 30 & 20 \\
\hline & total & 100 & 100 & 100 & 100 & 100 & 100 & 100 \\
\hline \multirow{5}{*}{$20+K$} & lenho & 63 & 45 & 22 & 22 & 0 & 11 & 45 \\
\hline & casca & 9 & 18 & 33 & 39 & 25 & 30 & 15 \\
\hline & galho & 9 & 10 & 23 & 11 & 21 & 27 & 19 \\
\hline & folha & 19 & 27 & 22 & 28 & 54 & 32 & 21 \\
\hline & total & 100 & 100 & 100 & 100 & 100 & 100 & 100 \\
\hline \multirow{5}{*}{$40+K$} & lenho & 61 & 45 & 19 & 22 & 0 & 6 & 42 \\
\hline & casca & 9 & 20 & 41 & 38 & 27 & 23 & 14 \\
\hline & galho & 9 & 8 & 21 & 11 & 18 & 28 & 24 \\
\hline & folha & 21 & 27 & 19 & 29 & 55 & 43 & 20 \\
\hline & total & 100 & 100 & 100 & 100 & 100 & 100 & 100 \\
\hline
\end{tabular}


Os eucaliptos testemunhas apresentaram maior acúmulo de $\mathrm{N}, \mathrm{P}, \mathrm{Ca}, \mathrm{Mg}$ e S nas folhas das copas, proporcionalmente, em relação aos outros componentes, do que os eucaliptos que receberam tratamento. Como essas árvores apresentaram um atraso no desenvolvimento em relação às demais, o maior conteúdo de nutrientes nas folhas de suas copas aos cinco anos de idade reflete a defasagem que ocorre para a formação do aparato fotossintético quando não há entrada de fertilizantes no ecossistema ou fertilidade natural do solo. Há maior demora no processo, mas os eucaliptos que não são adubados conseguem se estabelecer e extrair os nutrientes necessários para investir na realização da fotossíntese. Isso acontece em detrimento do acúmulo de nutrientes no lenho, o que faz com que os eucaliptos testemunhas apresentem, proporcionalmente, menores conteúdos imobilizados no lenho para a maioria dos nutrientes.

Em relação ao $\mathrm{Ca}$, para todos os tratamentos houve maior acúmulo nos componentes folha e casca. Para as árvores do tratamento testemunha, o componente folha foi maior do que o componente casca, no tratamento "ad" foram iguais e nos tratamentos com aplicação de biossólido o componente casca acumulou mais $\mathrm{Ca}$ do que as folhas da copa.

Em seu trabalho de revisão, Gonçalves et al. (2000) encontraram as seguintes partições dos conteúdos de nutrientes entre os componentes: N (31\% nas folhas, $29,5 \%$ na madeira, $20 \%$ na serapilheira, $11 \%$ nas cascas e $8,5 \%$ nos galhos); P (31\% na madeira, $28 \%$ nas cascas, $22 \%$ nas folhas); Ca (30\% nas cascas, $29 \%$ na serapilheira, $18 \%$ na madeira). Eles relatam que há uma forte relação entre a taxa de crescimento e a captura e acúmulo de nutrientes nas plantações de eucalipto, principalmente para o $\mathrm{N}$.

Analisando a questão da exportação de nutrientes com a colheita dos eucaliptos, verifica-se que se apenas os troncos forem retirados da área, considerando as árvores que receberam fertilização mineral, haverá uma saída de $456 \mathrm{~kg} \mathrm{ha}^{-1}$ de N, 11 de P, 74 de Ca e 27 de Mg. Para o tratamento "10+KP", 
em relação à adubação, haveria um aumento de $14 \%$ na exportação de $\mathrm{N}$, de $54 \%$ de $\mathrm{P}$ e $89 \%$ de $\mathrm{Ca}$, e diminuição de $22 \%$ na saída de Mg. Para o tratamento "40+K", os valores seriam semelhantes no caso do $\mathrm{P}$ e do $\mathrm{Mg}$, sendo que para o $\mathrm{N}$ haveria uma diminuição de 4\% e elevação de $130 \%$ para o $\mathrm{Ca}$.

Em plantações florestais, a remoção de nutrientes com a colheita representa um considerável dreno no capital de nutrientes do ecossistema, pois uma grande proporção de nutrientes está na fitomassa (Poggiani, 1985; Gonçalves \& Barros, 1999). Segundo Vital et al. (1999), essas saídas de nutrientes através da exploração da biomassa lenhosa de eucalipto corresponderam a $66 \%$ do $\mathrm{N}, 81 \%$ do $\mathrm{P}, 70 \%$ do $\mathrm{K}, 80 \%$ do Ca e $76 \%$ do $\mathrm{Mg}$, em relação ao total de nutrientes que estavam estocados nas árvores. Normalmente, esses nutrientes devem ser repostos para se garantir a sustentabilidade produtiva do sítio e reequilibrar a ciclagem de nutrientes. Quando se aplica biossólido, a remoção de nutrientes e de elementos potencialmente perigosos com a colheita das árvores, incorporando e diluindo esses nutrientes em cadeias produtivas, pode ser interessante para evitar acúmulo excessivo de elementos. Esse fato tornaria a área apta a receber novas aplicações, sem comprometer a sustentabilidade produtiva e ambiental do ecossistema.

A seguir é realizada a comparação entre tratamentos para os coeficientes de utilização biológica (CUB), que relacionam a produtividade em fitomassa com o conteúdo de nutrientes acumulados nessa fitomassa, para cada tratamento (Tabela 24). 
Tabela 24. Efeito dos tratamentos sobre os coeficientes de utilização biológica (CUB $=\mathrm{kg}$ fitomassa lenho $/ \mathrm{kg}$ nutriente lenho), para árvores Eucalyptus grandis aos cinco anos de idade

\begin{tabular}{ccccccc}
\hline TT & N & P & Ca & Mg & Mn & Zn \\
\hline tt & 266 & 9772 & 4701 & 9633 & 34 & 265 \\
$\mathbf{a d}$ & 208 & 9890 & 3006 & 8791 & 58 & 375 \\
$\mathbf{1 0 + K P}$ & 205 & 7638 & 1605 & 10207 & 78 & 258 \\
$\mathbf{2 0 + K}$ & 186 & 7622 & 1283 & 10212 & 135 & 275 \\
$\mathbf{4 0 + K}$ & 191 & 7581 & 1339 & 10382 & 320 & 321 \\
\hline
\end{tabular}

Não é apresentado o CUB para o elemento S, já que não foi detectado teor desse nutriente no material lenhoso. Verifica-se na tabela acima que a aplicação de biossólido, em relação aos tratamentos testemunha e adubação mineral, propiciou a redução dos CUBs para os nutrientes $\mathrm{N}, \mathrm{P}, \mathrm{Ca}$; e o aumento dos CUBs para Mg e Mn. O elemento Zn apresentou maior CUB nos eucaliptos que receberam adubação mineral (ad) e menor valor nos eucaliptos que receberam $10 \mathrm{Mg} \mathrm{ha}^{-1}$ de biossólido e $\mathrm{P}$ mineral na base $(10+\mathrm{KP})$. Isso indica que os eucaliptos que receberam biossólido, para produzir uma mesma quantidade de madeira do que os eucaliptos dos tratamentos "ad" e "tt", imobilizaram maiores conteúdos de N, P e Ca; e menores conteúdos de Mg e Mn. No entanto, o CUB não tem relação direta com a produtividade, pois plantas com elevada produtividade em matéria seca e elevado conteúdo de nutriente imobilizado podem ter o mesmo CUB de plantas com baixa produtividade e que imobilizaram um pequeno conteúdo de nutriente. O CUB vem sendo utilizado em estudos de nutrição florestal e ciclagem de nutrientes de maneira generalizada e sem os devidos cuidados que sua interpretação exige. A quantidade de nutrientes imobilizados na fitomassa, normalmente avaliados em uma determinada idade, não representa o total de nutrientes que foi utilizado para constituir essa fitomassa e a eficiência de uso dos nutrientes. 
Segundo Laclau et al. (2003), o requerimento de nutrientes durante a rotação foi, aproximadamente, quatro vezes maior para N, Ca e Mg, e duas vezes maior para o $\mathrm{P}$, do que a imobilização ao final de sete anos nos componentes lignificados dos eucaliptos. A formação da casca demandou durante a rotação, aproximadamente, a mesma quantidade de $\mathrm{P}$, Ca e Mg do que a formação do lenho, apesar da produção de fitomassa de casca ser cerca de dez vezes inferior.

Além da diferenciação e formação dos tecidos, os elementos minerais acumulados nos diferentes compartimentos estão envolvidos na fotossíntese e na divisão celular. A quantidade de nutrientes imobilizada em cada compartimento da planta vai depender de processos específicos que ocorrem nos diferentes tecidos vegetais e são afetados por aspectos como a retranslocação interna dos nutrientes móveis e aspectos da eficiência fisiológica de cada nutriente, influenciados por variáveis como a idade da árvore e características do sítio, principalmente, a disponibilidade de nutrientes no solo. Estudos da dinâmica de extração e acúmulo dos nutrientes nas árvores em várias idades ao longo das rotações e do ciclo, apesar de mais onerosos, devem ser privilegiados. Laclau et al. (2003), mostraram que a eficiência de uso dos nutrientes (CUB) aumentou com a idade do povoamento, mais acentuadamente para $\mathrm{Mg}$ e $\mathrm{K}$ do que para $\mathrm{N}, \mathrm{P}$ e Ca. Esse aumento foi atribuído ao aumento da proporção de cerne em relação à biomassa total das árvores durante seu crescimento. 


\subsubsection{Serapilheira e biossólido remanescente sobre o solo}

$\mathrm{Na}$ Tabela 25 são apresentados os valores da fitomassa de serapilheira que constituía a manta florestal sobre o solo e o estoque de nutrientes armazenados nessa serapilheira, cinco anos após o plantio dos eucaliptos.

Tabela 25. Valores médios ( $n=12)$ de fitomassa seca de serapilheira (serap) acumulada sobre o solo e da mineralomassa de nutrientes em cada tratamento, cinco anos após o plantio dos eucaliptos

\begin{tabular}{|c|c|c|c|c|c|c|c|c|}
\hline TT & $\begin{array}{l}\text { serap. } \\
M q h^{-1}\end{array}$ & $\mathbf{N}$ & $\mathbf{P}$ & $\mathrm{Ca}$ & $\mathrm{Mg}$ & $\begin{array}{r}\mathbf{S} \\
-1\end{array}$ & Mn & $\mathrm{Zn}$ \\
\hline tt & 12,58 & 121,1 & 4,0 & 83,6 & $\begin{array}{c}\mathrm{ng} \\
9,4\end{array}$ & 5,9 & 5,181 & 0,184 \\
\hline ad & 16,75 & 163,6 & 5,4 & 101,2 & 16,9 & 9,5 & 6,247 & 0,271 \\
\hline $10+K P$ & 16,50 & 163,4 & 8,2 & 175,9 & 10,5 & 12,5 & 5,715 & 0,699 \\
\hline $20+K$ & 14,64 & 152,5 & 7,8 & 232,0 & 9,5 & 9,9 & 4,210 & 0,782 \\
\hline $40+K$ & 15,93 & 186,0 & 17,1 & 359,6 & 13,5 & 14,7 & 4,557 & 2,763 \\
\hline
\end{tabular}

Observa-se que nas parcelas dos tratamentos "ad" e "10+KP" foi acumulada maior quantidade de serapilheira. Isso se refletiu em maior conteúdo de nutrientes, considerando os dois tratamentos, para o elemento $\mathrm{Mn}$ e considerando apenas o tratamento "ad", para o elemento Mg. As parcelas do tratamento " $40+K$ ", onde foi aplicada a maior dose de biossólido, apresentaram serapilheira com maior conteúdo de N, P, Ca, S e Zn. Os conteúdos de Zn e de Ca na serapilheira foram crescentes com as doses de biossólido. Como o biossólido apresenta elevados teores desses nutrientes e eles são praticamente imóveis dentro da planta, se acumulando nos tecidos senescentes, houve uma maior reciclagem e efeito proporcional às doses para o retorno desses nutrientes, como pode ser observado com a deposição do folhedo (Figuras $13 \mathrm{e}$ 16). Além disso, durante um ano em que o processo de decomposição do folhedo foi acompanhado, o $\mathrm{Zn}$ apresentou forte acúmulo líquido e o $\mathrm{Ca}$ 
apresentou a menor liberação entre os elementos analisados, o que potencializa o efeito do biossólido sobre o acúmulo desses nutrientes na serapilheira acumulada sobre o solo.

$\mathrm{Na}$ Tabela 26 pode-se observar o total de matéria seca do resíduo e os conteúdos de nutrientes remanescentes na massa de biossólido, cinco anos após a aplicação. 
Tabela 26. Médias $(n=12)$ da massa de biossólido remanescente $(M R)$ e dos conteúdos de nutrientes no biossólido coletado, cinco anos após a aplicação, nas parcelas de cada tratamento (TT) onde foi aplicado o resíduo. Cada amostra foi separada em duas texturas (TX): F (de 1 a $2 \mathrm{~mm}$ ) e $\mathrm{G}$ (> $2 \mathrm{~mm}$ )

\begin{tabular}{|c|c|c|c|c|c|c|c|c|c|}
\hline & & MR & $\mathbf{N}$ & $\mathbf{P}$ & $\mathrm{Ca}$ & $\mathbf{M g}$ & $S$ & Mn & $\mathrm{Zn}$ \\
\hline TT & TX & -- & & & & & & & --- \\
\hline $10+K P$ & G & 3824 & 61 & 33 & 339 & 10 & 10 & 0,5 & 6,7 \\
\hline $10+K P$ & F & 1420 & 15 & 6 & 62 & 2 & 2 & 1,6 & 1,3 \\
\hline $10+K P$ & $F+G$ & & $\underline{76}$ & $\underline{39}$ & $\underline{401}$ & $\underline{12}$ & $\underline{12}$ & $\underline{2,0}$ & $\underline{8,1}$ \\
\hline $20+K$ & $\mathbf{G}$ & 5931 & 45 & 32 & 388 & 9 & 10 & 1,1 & 6,7 \\
\hline $20+K$ & $F$ & 2000 & 30 & 29 & 247 & 6 & 6 & 0,6 & 4,3 \\
\hline $20+K$ & $F+G$ & & $\underline{75}$ & $\underline{60}$ & $\underline{636}$ & $\underline{15}$ & $\underline{16}$ & $\underline{1,6}$ & $\underline{11,1}$ \\
\hline $40+K$ & $\mathbf{G}$ & 18102 & 161 & 124 & 1686 & 32 & 29 & 1,7 & 23,7 \\
\hline $40+K$ & $F$ & 5649 & 21 & 13 & 161 & 3 & 3 & 1,2 & 2,1 \\
\hline $40+K$ & $\mathbf{F}+\mathbf{G}$ & & 182 & $\underline{137}$ & 1847 & $\underline{35}$ & $\underline{32}$ & $\underline{2,9}$ & $\underline{25,8}$ \\
\hline
\end{tabular}

Verifica-se que ainda há um considerável estoque de nutrientes no biossólido remanescente. Apenas os nutrientes $\mathrm{Mg}$ e $\mathrm{S}$, que apresentaram elevadas taxas líquidas de saída do biossólido (Tabela 16), estão com conteúdos relativamente baixos, cinco anos após a aplicação. O N, que também apresentou elevada liberação do biossólido mas que tinha um teor inicial elevado, ainda encontra-se com conteúdo capaz de atender as necessidades dos eucaliptos em uma segunda rotação, principalmente, no tratamento "40+K" onde foi aplicada a maior dose do resíduo. 


\subsubsection{Solo}

O efeito da aplicação do biossólido sobre a disponibilidade de nutrientes no solo, cinco anos após a aplicação, pode ser observado a seguir (Tabela 27).

Tabela 27. Efeito dos tratamentos (TT) sobre os teores de nutrientes lábeis (disponíveis/trocáveis) na camada de 0-10 cm do solo, cinco anos após a aplicação do biossólido

\begin{tabular}{cccccccc}
\hline TT & $\mathbf{N}$ & $\mathbf{P}$ & $\mathbf{C a}$ & $\mathbf{M g}$ & $\mathbf{S}$ & $\mathbf{M n}$ & $\mathbf{Z n}$ \\
\hline $\mathbf{t t}$ & 7,3 & 2,6 & 30,4 & 20,9 & 4,9 & 0,3 & 0,2 \\
$\mathbf{a d}$ & 8,4 & 1,9 & 34,2 & 20,6 & 0,9 & 0,4 & 0,3 \\
$\mathbf{1 0}+\mathbf{K P}$ & 8,8 & 9,5 & 218,4 & 20,7 & 9,9 & 0,9 & 1,6 \\
$\mathbf{2 0}+\mathbf{K}$ & 12,7 & 19,1 & 437,1 & 20,9 & 8,9 & 1,1 & 2,5 \\
$\mathbf{4 0}+\mathbf{K}$ & 8,4 & 40,7 & 629,5 & 21,0 & 20,6 & 0,9 & 3,8 \\
\hline
\end{tabular}

De maneira geral, a aplicação de biossólido aumentou a proporção de nutrientes disponíveis. Verifica-se que, mesmo após cinco anos, a aplicação inicial de biossólido continua mantendo um efeito evidente sobre a fertilidade do solo e sobre as concentrações lábeis de nutrientes, potencialmente disponíveis aos eucaliptos. Observa-se aumentos nos teores de todos os nutrientes avaliados, exceto $\mathrm{Mg}$, na camada de 0 a $10 \mathrm{~cm}$; principalmente nos teores de $\mathrm{P}$, $\mathrm{Ca}$ e $\mathrm{Zn}$, que apresentaram valores mais de dez vezes superiores no solo que recebeu biossólido do que os valores observados no solo dos tratamentos "tt" e "ad".

O teor de Mn disponível aumentou, aproximadamente, de duas a três vezes seu valor no solo que recebeu biossólido em relação aos tratamentos "tt" e "ad". Esse fato mostra que a diminuição dos teores e conteúdos de Mn nos componentes dos eucaliptos (Tabelas 20 e 21), e nas folhas durante avaliação nutricional (Guedes e Poggiani, 2003), quando se aplica biossólido alcalino, não 
é por causa do aumento do $\mathrm{pH}$ do solo. Essa hipótese levantada por vários autores (Tsadilas et al., 1995; Sloan \& Basta, 1995; Anjos \& Mattiazzo, 2000; Christie et al., 2001; Guedes \& Poggiani, 2003) se fundamenta no fato de que o aumento do $\mathrm{pH}$ precipitaria o $\mathrm{Mn}$ diminuindo sua forma disponível no solo. No entanto, correlações negativas entre $\mathrm{o}$ pH do solo e o $\mathrm{Mn}$ nas plantas não implicam em relação de causa e efeito, sendo que a variação em ambos os atributos podem ser derivadas de um terceiro fator, que seria o excesso de $\mathrm{Ca}$ proveniente do biossólido. Assim, como não se observou diminuição do Mn disponível no solo com a aplicação de biossólido, a principal hipótese para explicar a diminuição na absorção de Mn pelos eucaliptos é a competição entre o Ca e o Mn durante o processo de extração dos nutrientes pelas raízes. Como ambos são cátions bivalentes com raios iônicos de tamanhos aproximados, há uma competição direta entre eles pelos sítios de absorção e o excesso de $\mathrm{Ca}$ pode ter inibido a entrada de Mn nas raízes.

Os teores disponíveis de $\mathrm{S}^{-\mathrm{SO}_{4}}{ }^{-}$também aumentaram quando foi aplicado biossólido, enquanto que, onde foi aplicado fertilizante mineral, houve diminuição em suas concentrações. Vaz (2000), trabalhando na mesma área experimental, também observou significativos aumentos do $\mathrm{S}^{-} \mathrm{SO}_{4}{ }^{-}$no solo com a aplicação de biossólido. Em Vancouver (Canadá), árvores tratadas com fertilizantes inorgânicos sofreram deficiência de $\mathrm{S}$, enquanto áreas tratadas com biossólido não apresentaram essa deficiência (Weetman et al., 1993). Guedes \& Poggiani (2003) também detectaram diminuição nos teores foliares dos eucaliptos que receberam fertilizante mineral em relação aos que receberam aplicação de biossólido.

Segundo Gonçalves et al. (1996), em solos com conteúdo de argila < $15 \%$, o que é o caso do solo em estudo, quando for detectado conteúdo de $\mathrm{P}$ disponível extraído com resina $>8 \mathrm{mg} \mathrm{dm}^{-3}$ não é necessária adubação fosfatada para plantio de eucalipto. O solo das parcelas de todos os tratamentos que receberam biossólido apresentou teores maiores do que $8 \mathrm{mg}$ 
$\mathrm{dm}^{-3}$, dispensando a necessidade de novas adubações fosfatadas para conduzir a segunda rotação dos eucaliptos ou para reformar a área.

Utilizando os dados de densidade aparente para calcular a massa do solo e de teores disponíveis/trocáveis e teores totais dos nutrientes, foram calculados o capital lábil na primeira camada e o estoque total de nutrientes até $30 \mathrm{~cm}$ do perfil do solo. Na Tabela 28 pode-se observar o efeito da aplicação do biossólido e de fertilizantes minerais sobre o conteúdo lábil de nutrientes na primeira camada do perfil do solo. As diferenças entre as médias dos tratamentos foram significativas para os seguintes elementos: $P(F=19,63$; $p<0,001)$, Ca $(F=17,39 ; p<0,001), S(F=6,03 ; p=0,004), M n(F=5,35 ; p=0,007)$, Zn $(F=19,89 ; p<0,001)$.

Tabela 28. Efeito dos tratamentos sobre o capital lábil de nutrientes disponíveis/trocáveis na camada de $0-10 \mathrm{~cm}$ do perfil do solo

\begin{tabular}{cccccccc}
\hline TT & $\mathbf{N}$ & $\mathbf{P}$ & $\mathbf{C a}$ & $\mathbf{M g}$ & $\mathbf{S}$ & $\mathbf{M n}$ & $\mathbf{Z n}$ \\
\hline $\mathbf{t t}$ & 9 & 3 & 38 & 26 & 6 & 0,4 & 0,3 \\
$\mathbf{a d}$ & 11 & 3 & 45 & 28 & 1 & 0,5 & 0,4 \\
$\mathbf{1 0 + \mathbf { K P }}$ & 11 & 11 & 256 & 24 & 12 & 1,1 & 1,9 \\
$\mathbf{2 0}+\mathbf{K}$ & 15 & 21 & 492 & 24 & 10 & 1,2 & 2,8 \\
$\mathbf{4 0 +} \mathbf{K}$ & 11 & 54 & 834 & 27 & 27 & 1,2 & 4,9 \\
\hline
\end{tabular}

Verifica-se que a aplicação de biossólido aumentou os estoques de nutrientes no solo, na forma lábil, para a maioria dos elementos, principalmente, $\mathrm{Ca}, \mathrm{P}$ e Zn. Onde foi realizada a adubação mineral, pode-se observar que não houve diferença em relação ao solo testemunha. Isso mostra que a aplicação de biossólido, quando comparada com a aplicação de fertilizante mineral, tem um efeito mais duradouro e sustentável. O solo que recebeu a maior dose de biossólido apresentou teores significativamente maiores do que o solo que 
recebeu fertilização mineral: $P(p<0,001), \mathrm{Ca}(p<0,001), S(p=0,014), M n$ $(p=0,030), Z n(p<0,001)$. A quantidade de $P$, Ca e Zn disponível apenas na camada de 0 a $10 \mathrm{~cm}$ do perfil do solo que recebeu a maior dose do resíduo é suficiente para atender as necessidades da cultura de eucalipto em uma segunda rotação, sem necessidade de novas entradas de nutrientes. Segundo Ranger \& Turpault (1999), a manutenção, e se possível, o aumento da fertilidade do solo é o objetivo principal do manejo sustentável de florestas, pois ela é a principal responsável pela capacidade de produção de madeira.

$\mathrm{Na}$ Tabela 29 pode-se observar o efeito dos tratamentos sobre os estoques totais de nutrientes no solo.

Tabela 29. Variação nos estoques de nutrientes totais no solo até $30 \mathrm{~cm}$ de profundidade (solo), em função dos tratamentos, cinco anos após a instalação do experimento

\begin{tabular}{|c|c|c|c|c|c|c|}
\hline & $\mathbf{N}$ & $\mathbf{P}$ & $\mathrm{Ca}$ & $\mathbf{M g}$ & Mn & $\mathrm{Zn}$ \\
\hline $\mathrm{tt}$ & 1697 & 1822 & 565 & 684 & 598 & 70 \\
\hline ad & 1893 & 1827 & 860 & 753 & 622 & 102 \\
\hline $10+K P$ & 1666 & 1882 & 1709 & 769 & 602 & 78 \\
\hline $20+K$ & 1726 & 1993 & 2077 & 835 & 617 & 98 \\
\hline $40+K$ & 1987 & 2727 & 3977 & 969 & 658 & 153 \\
\hline
\end{tabular}

A aplicação do biossólido aumentou, de maneira significativa, os reservatórios totais no solo apenas para dois dos nutrientes avaliados. Houve efeito significativo dos tratamentos apenas sobre o Ca $(F=5,5224 ; p=0,006)$ e Zn $(F=8,4744 ; p=0,001)$. As diferenças entre as médias dos tratamentos foram significativas apenas entre os tratamentos "40+K" e "tt" $(p=0,006)$ e entre "40+K" e "ad" ( $p=0,011)$. O solo que recebeu a maior dose de biossólido apresentou maior conteúdo de $\mathrm{Ca}$ do que o solo testemunha e do que o solo com adubação mineral. No caso do Zn, as únicas diferenças significativas foram 
as do tratamento "40+K" em relação aos outros tratamentos: "tt" $(0,001)$, "ad" $(0,038)$, "10+KP" $(0,002)$, "20+K" $(0,022)$.

Quando se analisa as quantidades de nutrientes adicionadas com os tratamentos e as quantidades estocadas a mais nos compartimentos, devido aos tratamentos, há uma certa incoerência. Algumas vezes, a quantidade do nutriente estocada a mais no solo, em relação ao tratamento testemunha, é maior do que a quantidade disponibilizada pelo tratamento. Harrison et al. (1994b) também relataram um evidente problema ao realizar o balanço do $P$ em florestas que receberam biossólido. Segundo esses autores, a quantidade de $P$ adicionada com aplicação de biossólido foi menor do que a diferença de $\mathrm{P}$ total no solo corrigido em relação ao testemunha. Ainda segundo Harrison et al. (1994 b), pouco se sabe sobre a variação ao longo do tempo do conteúdo de nutrientes no ecossistema após aplicação de biossólido. Muitos pesquisadores têm especulado que a aplicação de biossólido pode resultar, a longo prazo, em uma retenção dos nutrientes, devido à conservação dos mesmos com a intensificação da ciclagem e com o maior desenvolvimento das árvores.

Além da própria entrada de nutrientes através da adição de fertilizantes e biossólido, podem ocorrer efeitos secundários com a aplicação dos tratamentos, que influenciarão diretamente o balanço de nutrientes no ecossistema. A aplicação de biossólido pode alterar outros mecanismos de entrada de nutrientes, como a fixação biológica de $\mathrm{N}$, além dos próprios mecanismos de retenção ou perda do ecossistema, como a porosidade do solo. Além disso, a resposta da vegetação é distinta entre os tratamentos, o que pode levar, por exemplo, a maior desenvolvimento do sistema radicular e exploração de camadas mais profundas em determinados tratamentos.

$\mathrm{Na}$ Tabela 30 podem ser observados os valores do coeficiente de utilização aparente dos nutrientes avaliados, para os diversos tratamentos. Esses coeficientes representam a relação entre as quantidades de nutrientes imobilizados a mais nos eucaliptos tratados em relação aos eucaliptos 
testemunhas e as quantidades totais de nutrientes que foram introduzidas no ecossistema com a aplicação de cada tratamento.

Tabela 30. Influência dos tratamentos (TT) no coeficiente de utilização aparente (CUA) de cada nutriente, calculado de acordo com Labrecque (1995)

\begin{tabular}{ccccccccc}
\hline & $\mathbf{T T}$ & $\mathbf{N}$ & $\mathbf{P}$ & $\mathbf{C a}$ & $\mathbf{M g}$ & $\mathbf{S}$ & $\mathbf{M n}$ & $\mathbf{Z n}$ \\
& $\mathbf{a d}$ & 2,76 & 0,26 & 0,17 & 0,13 & 0,13 & & 0,05 \\
CUA & $\mathbf{1 0 + K P}$ & 1,78 & 0,17 & 0,18 & 0,35 & 0,06 & 0,18 & 0,02 \\
& $\mathbf{2 0 + K}$ & 0,56 & 0,05 & 0,09 & 0,06 & 0,01 & $-0,64$ & 0,01 \\
& $\mathbf{4 0 + K}$ & 0,31 & 0,03 & 0,06 & 0,06 & 0,01 & $-0,39$ & 0,00 \\
\hline
\end{tabular}

Para a maioria dos nutrientes, o tratamento "ad" apresentou os maiores CUAs, indicando que os nutrientes aplicados via fertilização mineral foram, proporcionalmente, mais utilizados pelos eucaliptos. Com a utilização de biossólido há uma diminuição nos CUAs e uma relação inversa com a dose aplicada. Isso indica que, o aumento do potencial de nutrientes com o aumento da dose não se reflete, proporcionalmente, em uma maior utilização dos nutrientes pelos eucaliptos.

No caso do N, verifica-se na Tabela 30 que para os tratamentos "ad" e "10+KP", os CUAs foram maiores do que a unidade, indicando que os eucaliptos absorveram e imobilizaram mais $\mathrm{N}$ do que as quantidades aplicadas com esses tratamentos. Quando se aplicou a dose de $20 \mathrm{Mg} \mathrm{ha}^{-1}(20+\mathrm{K}), 56 \%$ do $\mathrm{N}$ foi imobilizado nos eucaliptos com cinco anos, e na dose de $40 \mathrm{Mg} \mathrm{ha}^{-1}$ $(40+K), 31 \%$ foi imobilizado. Como ainda há quantidade considerável de $\mathrm{N}$ no biossólido remanescente e há consideráveis perdas por volatilização de Amônia devido à aplicação superficial (Zhang et al., 2004), verifica-se que, realmente, o potencial de lixiviação de nitrato e contaminação do lençol freático é mínimo. Andrade \& Mattiazo (2000) e Velasco-Molina (2004), também constataram que 
não houve lixiviação de nitrato com aplicação de biossólido na mesma área experimental em que foi desenvolvido este trabalho.

Os CUAs negativos para o elemento $\mathrm{Mn}$, nos tratamentos " $20+\mathrm{K}$ " e "40+K", mostram que houve maior imobilização do elemento nos eucaliptos testemunhas, reforçando a questão de que a aplicação de biossólido alcalino diminui a absorção desse nutriente pelos eucaliptos. 


\section{CONSIDERAÇÕES FINAIS E CONCLUSÕES}

Os vários resultados apresentados mostraram que a aplicação do biossólido alterou o desenvolvimento e o estado nutricional das árvores, bem como os padrões de reciclagem dos nutrientes. Houve um significativo incremento na produção de fitomassa epígea pelos eucaliptos que receberam $10 \mathrm{Mg} \mathrm{ha}^{-1}$ de biossólido mais $\mathrm{K}$ e $\mathrm{P}$ mineral, em relação ao tratamento testemunha, e maior produção média do que os eucaliptos que receberam fertilização mineral completa. Com as doses crescentes de biossólido, verificase também um significativo aumento da produção de serapilheira (principalmente folhas) e na devolução de nutrientes ao solo, estimulando o processo de reciclagem biogeoquímica.

De maneira geral, os efeitos da aplicação do biossólido podem ser observados ao longo e até a fase final da primeira rotação da cultura de eucalipto, sendo que a influência sobre a vegetação é mais acentuada na fase inicial e intermediária do que ao final da rotação. Este aspecto, entretanto, pode estar relacionado à competição por luz e água, que sempre se estabelece mais acentuadamente quando as árvores se encontram em um estágio mais adiantado de crescimento e a competição intra-específica é mais acentuada, tornando esses fatores mais limitantes ao crescimento do que a disponibilidade de nutrientes.

A comparação entre a área testemunha e as áreas onde foram realizadas a aplicação de fertilizantes minerais e a aplicação de biossólido, evidencia que o resíduo melhorou a fertilidade do solo ao final da rotação, enquanto que a adubação convencional não foi capaz de manter os estoques de nutrientes. A aplicação de biossólido assegura maior sustentabilidade 
ecossistema, do ponto de vista nutricional, do que a adubação mineral. Os incrementos observados na disponibilidade de nutrientes no solo onde foi aplicado biossólido, mostram que o resíduo é capaz de atender boa parte da necessidade de adubação para conduzir uma segunda rotação da cultura.

Em relação às hipóteses iniciais que nortearam o desenvolvimento do trabalho, chegou-se às seguintes conclusões:

1) a aplicação de biossólido propicia maior deposição de serapilheira pelos eucaliptos, principalmente, folhas, propiciando maior reciclagem de nutrientes das árvores para a manta florestal em áreas que receberam o resíduo. Em relação à entrada de material orgânico no ecossistema, o efeito indireto do biossólido, em conseqüência do aumento da produção de fitomassa e da reciclagem biogeoquímica pode ser maior do que a própria matéria orgânica adicionada inicialmente com a aplicação do biossólido.

2) O biossólido alcalino utilizado é um material que apresenta baixas taxas de degradação. A aplicação de biossólido não altera a taxa de perda de massa do folhedo de eucalipto depositado sobre o solo, avaliada com folhas senescentes coletadas após quatro anos de plantio. No entanto, o resíduo afeta a dinâmica de mineralização e liberação de nutrientes, principalmente, evitando a imobilização de N e acelerando sua liberação das folhas em decomposição.

3) Na fase final da rotação, o biossólido propicia aumento nos estoques de nutrientes de todos os compartimentos do ecossistema (biomassa arbórea, serapilheira ou manta florestal e solo). Mesmo com a maior imobilização na fitomassa dos eucaliptos, o biossólido também propicia maior retorno de nutrientes ao solo, aumentando o estoque lábil de nutrientes no solo ao final da rotação e mantendo a sustentabilidade em relação à capacidade produtiva do 
sítio. A aplicação de biossólido não altera a partição de fitomassa entre os componentes das árvores de eucalipto. Apesar disso, modifica a partição da mineralomassa nesses componentes, sendo que, proporcionalmente, os eucaliptos que recebem biossólido apresentam na fase final da primeira rotação, menores estoques de nutrientes nas copas, principalmente nas folhas, do que os eucaliptos testemunhas. 


\section{REFERÊNCIAS BIBLIOGRÁFICAS}

ABER, J.D.; MELILLO, J.M. Litter decomposition: measuring relative contributions of organic matter and nitrogen to forest soils. Canadian Jornal of Botany, v.58, p.416-421, 1980.

AGENDA 21 BRASILEIRA, Conferência das Nações Unidas sobre o Meio Ambiente e desenvolvimento. Brasília, Câmara dos Deputados, Coordenação de Publicações, 1995. 472p.

ALMENDROS, G.; DORADO, J. GONZÁLEZ-VILA, F.J.; BLANCO, M.J.; LANKES, U. ${ }^{13} \mathrm{C}$ NMR assessment of decomposition patterns during composting of forest and shrub biomass. Soil Biology e Biochemistry, v.32, p.793-804, 2000.

ANDERSON, J.M.; INGRAM, J.S.I. (Ed). Tropical soil biology and fertility: a handbook of methods. Wallington, UK: C.A. B. International, 1993.

ANDRADE, C.A. Nitratos e metais pesados em solos e plantas de Eucalyptus grandis após aplicação de biossólidos da ETE Barueri. Piracicaba, 1999. 65p. Dissertação (Mestrado) - Escola Superior de Agricultura "Luiz de Queiroz", Universidade de São Paulo.

ANDRADE, C.A. Fração orgânica de biossólidos e efeito no estoque de carbono e qualidade da matéria orgânica de um Latossolo cultivado com eucalipto. Piracicaba, 2005. 121p. Tese (Doutorado) - Escola Superior de Agricultura "Luiz de Queiroz", Universidade de São Paulo.

ANDRADE, C.A.; MATTIAZZO, M.E. Nitratos e metais pesados no solo e nas árvores após aplicação de biossólido (lodo de esgoto) em plantações florestais de Eucalyptus grandis. Scientia Forestalis, v.58, p.59-72, 2000.

ANJOS, A.R.M.; MATTIAZZO, M.E. Metais pesados em plantas de milho cultivadas em latossolos repetidamente tratados com biossólido. Scientia Agricola, v.57, n.4, p.1-16, 2000.

ARNOLD, K.; MAGAI, R.; HOORMANN, R.; MILES, R. Safety and benefits of biosolids. http://mnextension.missouri.edu/xplor/waterq/wq0427.htm (14 abril 1998) 
ASSUNÇÃO, J.C.B. de Análise mineralógica, geoquímica e textural de lodos gerados e dispostos pela ETE de Barueri-SP: associações com metais pesados e seus efeitos no solo. São Paulo, 1995. 120p. Dissertação (Mestrado) - Instituto de Geociências/Universidade de São Paulo.

ATTIWILL, P.M. Nutrient cycling in a Eucalyptus oblique forest: 4 - nutrient uptake and nutrient return. Australian Journal of Botany, v.28, p.199-222, 1980.

ATTIWILL, P.M.; ADAMS, M.A. Tansley review No.50: Nutrient cycling in forests. New Phytologist, v.124, p.561-582, 1993.

BERG, B.; STAAF, $H$. Leaching, accumulation and release of nitrogen in decomposing forest litter. In: CLARK, F. E.; ROSSWALL, T. (Ed). Terrestrial nitrogen cycles. Ecological Bulletin, v. 33, p.163-178, 1981.

BERTON, R.S. Riscos de contaminação do agroecossistema com metais pesados. In: BETTIOL, W.; CAMARGO, O. A. (Ed). Impacto ambiental do uso agrícola do lodo de esgoto. Jaguariúna: EMBRAPA Meio Ambiente, 2000, cap. 16, p.259-268.

BETTIOL, W.; CARVALHO, P.C.T. Utilização de lodo de esgoto primário e fertilizante organo-mineral IPT na cultura do milho. Fertilizantes, v.44, p.14$15,1982$.

BETTIOL, W.; CARVALHO, P.C.T.; FRANCO, B.J.D.C. Utilização do Lodo de esgoto como fertilizante. O solo, v.75, n.1, p.44-54, 1982.

BINKLEY, D.; DUNKIN, K.A.; DeBELL, D.; RYAN, M.G. Production and nutrient cycling in mixed plantations of Eucalyptus and Albizia in Hawaii. Forest Science, v.38, n.2, p.393-408, 1992.

BOARETO, A.E.; MURAO, K.A.T.; NAKAGAUA, J.; CHITOLINA, J.C. Níquel e Cádimo em grãos de feijão produzidos em solo incubado com Le. In: REUNIÃO BRASILEIRA DE FERTILIDADE DO SOLO E NUTRIÇÃO DE PLANTAS, 20. Piracicaba, 1992. Anais. Campinas: Fundação Cargil, 1992. p. $400-401$

BRACELPA (ASSOCIAÇÃO BRASILEIRA DE CELULOSE E PAPEL). Relatório Estatístico Florestal, 1999.60p. 
BUBB, K.A.; XU, Z.H.; SIMPSON, J.A.; SAFFIGNA, P.G. Some nutrient dynamics associated with litterfall and litter decomposition in hoop pine plantations of southeast Queensland, Australia. Forest Ecology and Management, v.110, p.343-352, 1989.

CAMARGO, F.A.O.; SANTOS, G.A.; GUERRA, J.G.M. Macromoléculas e substâncias húmicas. In: SANTOS, G.A.; CAMARGO, F.A.O. (Ed). Fundamentos da matéria orgânica do solo. Porto Alegre: Gênesis, 1999. p.27-40.

CARPANEZZI, A. P. Deposição de material orgânico e nutrientes em uma floresta natural e em uma plantação de eucaliptos no interior do Estado de São Paulo. Piracicaba, 1980, 107 p. Tese (Mestrado) - Escola Superior de Agricultura "Luiz de Queiroz", Universidade de São Paulo.

CARVALHO, P.C.T. Compostagem. In: TSUTYA, M.T.; COMPARINI, J.B.; ALEM SOBRINHO, P.; HESPANHOL, I.; CA'RVALHO, P.C.T.; MELF, A.J.; MELO, W.J.; MARQUE, M.O. (Ed). Biossólidos na agricultura. São Paulo: SABESP, 2001. cap. 6, p.181-207.

CARVALHO, P.C.T.; BARRAL, M.F. Aplicação de Le como fertilizante. Fertilizantes, v. 63, n. 2, p.1-4, 1981.

CERETTA, C.A.; BAYER, C.; DICK, D.P; MARTIN-NETO, L.; COLNAGO, L.A. Métodos espectroscópicos. In: SANTOS, G.A.; CAMARGO, F.A.O. (Eds.) Fundamentos da matéria orgânica do solo: ecossistemas tropicais e subtropicais. Porto Alegre: GENESIS, 1999. p.293-336.

CETESB (COMPANHIA DE TECNOLOGIA DE SANEAMENTO AMBIENTAL). Aplicação de lodos de sistemas de tratamento biológico em áreas agrícolas - Critérios para projeto e operação. São Paulo: CETESB, 1999. 32p. (Manual Técnico, P 4.230)

CHANEY, R.L. Public health and sludge utilization. Biocycle, v.30, p.68-73, 1990.

CHRISTIE, P.; EASSON, D.L.; PICTON, J.R.; LOVE, S.C.P. Agronomic value of alkaline-stabilized sewage biosolids for spring barley. Agronomy Journal, v.93, n.1, p.144-151, 2001.

CORRÊA, R.S.; CORRÊA, A.S. Valoração de biossólidos como fertilizantes e condicionadores de solos. SANARE, v.16, n.16, p.49-56, 2001. 
CROWDER, M.J.; HAND, D.J. Analysis of repeated measures. Londres: Chapman e Hall, 1990. 257p.

El-BAHA A.M. Growth response of Eucalyptus camaldulensis as affected by thinning and sewage sludge or inorganic fertilizer on a poor quality site. Alexandria Journal of Agricultural Research, v.46; n.1, p.269-, 2001, (Tree CD Abstract).

FARIA, L.C. Fertilização de povoamentos de eucalipto com biossólido da ETE de Barueri, SP: demanda potencial e nível mínimo de resposta. Piracicaba, 2000. 85p. Dissertação (Mestrado) - Escola Superior de Agricultura "Luiz de Queiroz", Universidade de São Paulo.

FARIA, L.C. de; RODRIGUES, L.C.E. Aplicabilidade de biossólido em plantações florestais: $V$. avaliação do potencial de uso do resíduo da ETE de Barueri, SP. In: BETTIOL, W.; CAMARGO, O. A. (Ed). Impacto Ambiental do Uso Agrícola do Lodo de Esgoto. Jaguariúna: EMBRAPA Meio Ambiente, 2000. cap.12, p.209-213.

FAO. Organic recycling in Asia. FAO Soils Bullettin, v.36, p.320-325, 1978.

FISKELL, J.G.A.; NEARY, D.G.; COMERFORD, N.B. Slach pine and understorey interception of micronutrients mineralized from sewage sludge applied to a sandy acidic forest soil. Forest Ecology and Management, v.37, n.1/3, p.27-36, 1990.

FOLHA DE SÃO PAULO. Promotora tenta barrar venda ilegal de lodo de esgoto. Publicado em 25/02/2003, http://www1.folha.uol.com.br/folha/dinheiro/ult91u63902.shtml (22 jul. 2004)

FORTES NETO, P. Degradação de biossólido incorporado ao solo avaliada através de medidas microbiológicas. Piracicaba, 2000. 113p. Tese (Doutorado) - Escola Superior de Agricultura "Luiz de Queiroz", Universidade de São Paulo.

FORTUNY, J.A.; FULLER, W.H. Trace metals in municipal sludges. Evaluation procedures for solid wastes. Biocycle, v.20, p.27-29, 1979.

GIBSON, T.S.; CHAN, K.Y.; SHARMA, G. SHEARMAN, R. Soil carbon sequestration utilising recycled organics. Sydney: NSW Agriculture, 2002. 95p. 
GILMOUR, J.T.; ROMAN, F.; CLARK, M.D. Decomposition of biosolids in a disposal site soil. Journal of Environmental Quality, v.25, p.1083-1086, 1996.

GONÇALVES, J.L.M.; BARROS, N.F. Improvement of site productivity for shortrotation plantations in Brazil. Bosque, v.20, n.1, p.89-106, 1999.

GONÇALVES, J.L.M.; RAIJ, B. van; GONÇALVES, J.C. IN: RAIJ, B. van; CANTARELLA, H.; QUAGGIO, J.A.; FURLANI, A.M.C. (Ed). Recomendações de adubação e calagem para o Estado de São Paulo. 2. ed. Campinas: Instituto Agronômico de Campinas \& Fundação IAC, 1996. p.247-259 (Boletim Técnico, 100)

GONÇALVES, J.L.M.; STAPE, J.L.; BENEDETI, V.; FESSEL, V.A.G.; GAVA, J.L. An evaluation of minimum and intensive soil preparation regarding fertility and tree nutrition. In: GONÇALVES, J.L.M.; BENEDETTI, V. (Ed). Forest Nutrition and fertilization. Piracicaba: Editora IPEF, 2000. cap. 2, p.13-64.

GUEDES, M.C. Efeito do lodo de esgoto (biossólido) sobre a nutrição, ciclagem de nutrients e crescimento de sub-bosque, em plantação de eucalipto. Piracicaba, 2000. 74p. Dissertação (Mestrado) - Escola Superior de Agricultura "Luiz de Queiroz", Universidade de São Paulo.

GUEDES, M.C.; POGGIANI, F. Variação dos teores de nutrientes foliares em eucalipto fertilizado com biossólido. Scientia Forestalis, v.63, p.188-201, 2003.

GUILLER, K.E.; CADISH, G.; PALM, C. The Norte-South divide! Organic wastes, or resources for nutrient management? Agronomie, v.22, p.703709, 2002.

GUO, L.B.; SIMS, R.E.H.; HORNE, D.J. Biomass production and nutrient cycling in Eucalyptus short rotation energy forests in New Zealand. I: biomass and nutrient accumulation. Bioresource Technology, v.85, p.273283, 2002.

HAMMEL, K.E. Fungal degradation of lignin. In: CADISCH, G.; GILLER, K.E. (Ed). Driven by nature: plante litter quality and decomposition. Londres: CAB internacional, 1997. p 33-46.

HARRISON, R.B.; HENRY, C.L.; XUE, D.S. Magnesium defeciency in Douglasfir and grand fir growing on a sandy outwash soil amended with sewage sludge. Water, Air and Soil Polluition, v.75, n.1/2, p.37-50, 1994a. 
HARRISON, R.; XUE, D.; HENRY, C.; COLE, D.W. Long-term effects of heavy applications of biosolids on organic matter and nutrient content of a coarsetextured forest soil. Forest Ecology and Management, v.66, p.165-177, 1994b.

HART, J.B.; NGUYEN, P.V.; URIE, D.H.; BROCKWAY, D.G. Silvicultural use of wastewater sludge. Jornal of Forestry, v.17, p.17-24, 1988.

HART, P.B.S.; CLINTON, P.W.; ALLEN, R.B.; NORDMEYER, A.H.; EVANS, G. Biomass and macro-nutrients (above and below-ground) in a New Zealand beech (Nothofagus) forest ecosystem: implications for carbon storage and sustainable forest management. Forest Ecology and Management, v.174, p. 281-294, 2003.

HENRY, C.L.; COLE, D.W. Use of biosolids in the forest: technology, economics and regulations. Biomass and Bioenergy, v.13, n.4/5, p.269277, 1997.

HENRY, C.L.; COLE, D.W.; HINCKLEY, T.M.; HARRISON, R.B. The use of municipal and pulp paper sludges to increase production in forestry. Journal of Sustainable Forestry, v.1, n.3, p.41-45, 1993.

HENRY, C.L.; COLE, D.W.; HARRISON, R.B.; BENGTSSON, J.; LUNDKVIST, $\mathrm{H}$. Use of municipal sludge to restore and improve site productivity in forestry: the Packe Forest Sludge Research Program. Forest Ecology and Management, v.66, n.1/3, p.137-149, 1994.

HSIEH, Y.P.; DOUGLAS, L.A.; MOTTO, H.L. Modeling sewage sludge in soil: I. Organic Carbon transformation. Journal of Environmental Quality, v.10, n.1, p.54-59, 1981.

KAPOSTS, V.; KARINS, Z.; LAZDINS, A. Use od sewage sludge in forest cultivation. Resumos (TreeCD Abstracts): Baltic Forestry, v.6, n.2, p.24-28, 2000.

KOLM, L.; POGGIANI, F. Ciclagem de nutrientes em povoamentos de Eucalyptus grandis submetidos à prática de desbastes progressivos. Scientia Forestalis, v.63, p.79-93, 2003.

KRONKA, F. J. N. et al. Mapeamento e quantificação do reflorestamento no estado de São Paulo. In: CONGRESSO FLORESTAL BRASILEIRO. 8. Benefícios, produtos e serviços da floresta: oportunidades e desafios do século XXI. CD, disco 2. São Paulo, 2003. 
LABRECQUE, M.; TEODORESCU, T.I.; DAICLE, S. Effect wasterwater sludge on grwnth and heavy metal bioaccumulation os two Salix species. Plant and Soil, v.17, n.1/2, p.303-316, 1995.

LACLAU, J.P; BOUILLET, J.P.; RANGER, J. Dynamics of biomass and nutrient accumulation in a clonal plantation of Eucalyptus in Congo. Forest Ecology and Management, v.128, p.181-196, 2000.

LACLAU, J.P.; DELEPORTE, F.; RANGER, J.; BOUILLET, J.P.; KAZZOTTI, G. Nutrient dynamics throughout the rotation of Eucalyptus clonal stands in Congo. Annals of Botany, v.9, p.1-14, 2003.

LANDSBERG, J.J.; GOWER, S.T. Applications of physiological ecology of forest management. San Diego: Academic Press, 1997. 354p.

LARCHER, W. Physiological plant ecology. 3. ed. Berlin: Springer-Verlag, 1995. 506p.

LEONARD, P.; McKINNEY, B. Biosolids application to forests - Implementation and operations. In: The forest alternative. Principles and practice of residuals use. p.73-78. In: INTERNATIONAL SYMPOSIUM ON THE USE OF RESIDUALS AS SOIL AMENDMENTS IN FOREST ECOSYSTEMS. Seattle: Proceedings, 1997.

LIMA, W.P. Impacto ambiental do eucalipto. 2. ed. São Paulo: Editora da Universidade de São Paulo, 1993. 301p.

LOUZADA, J.N.C.; SCHOEREDER, J.H.; De Marco Junior., P. Litter decomposition in semideciduous forest and Eucalyptus spp. crop in Brazil: a comparison. Forest Ecology and Management, v.94, p.31-36, 1997.

MALAVOLTA, E.; VITTI, E.C.; OLIVEIRA, S.A. Avaliação do estado nutricional das plantas (princípios e aplicações). 2. ed. Piracicaba: Associação Brasileira para Pesquisa da Potassa e do Fosfato, 1997. 319 p.

MARCIANO, C.R. Alterações nos atributos físico-hídricos do solo pela aplicação de resíduos urbanos. Piracicaba, 1999. 74p. Tese (Doutorado) - Escola Superior de Agricultura "Luiz de Queiroz", Universidade de São Paulo.

MARSCHNER, H. Mineral nutrition of higher plants. 2. ed. London: Academic Press, 1995, 889p. 
MARTINS, L. F. S. Configuração do sistema radicular das árvores de Eucalyptus grandis em resposta à aplicação de doses crescentes de bossólido. Piracicaba, 2002. 73p. Dissertação (Mestrado) - Escola Superior de Agricultura "Luiz de Queiroz", Universidade de São Paulo.

MATTHEWS, P. Sustainability in biosolids management. Water Science Techinology, v.38, n.2, p.97-102, 1998.

McNAB, W.H.; BERRY, C.R. Distribution of aboveground in three pine species planted on a devasted site amended with sewage sludge or inorganic fertilizer. Forest Science, v.31, n.2, p.373-382, 1985.

MELO, W.J.; MARQUES, M.O.; MELO, V.P. O uso agrícola do biossólido e as propriedades do solo. p.289-363. In: TSUTIYA, M.T.; COMPARINI, J.B.; SOBRINHO, P.A.; ESPANHOL, I.; CARVALHO, P.C.T.; MELFI, A.J.; MELO, W.J.; MARQUES, M.O. (Ed). Biossólidos na agricultura. São Paulo: SABESP, 2001. 468p.

MELO, W.J.; MARQUES, M.O.; SANTIAGO, G.; CHELLI, R.A.; LEITE, S.A.S. Efeitos de doses crescentes de lodo de esgoto sobre frações de matéria orgânica e CTC de um Latossolo cultivado com cana-de-açúcar. Revista Brasileira de Ciência do Solo, v.18, p.449-455, 1994.

MELO, V.P. de; BEUTLER, A.N.; SOUZA, Z.M. de; CENTURION, J.F.; MELO, W.J. de Atributos físicos de Latossolos adubados durante cinco anos com biossólido. Pesquisa Agropecuária Brasileira, v.39, n.1, p.67-72, 2004.

MILES R.; BROWN, J.R.; ARNOLD, K. Biosolids glossary of terms. Home page: http://mmextension.missouri.edu/xplor/waterq/wq0449.htm (14 abril 1998)

MORAIS, S.M.J.; ATAIDES, P.R.V.; GARCIA, D.C.; KURTZ, F.C.; OLIVEIRA, O.S.; WATZLAWICK, J.F. Uso de Le da CORSAN, Santa Maria (RS), comparado com outros substratos orgânicos. SANARE, p. 44-49, 1997.

NOVAIS, R. F.; BARROS, N. F.; COSTA, L. M. Aspectos nutricionais e ambientais do Eucalipto. Revista Brasileira de Silvicultura, v.18, n.68, p.10 - 17, 1996.

NOVAIS, R.F.; BARROS, N.F. de; NEVES, J.C.L. Nutrição mineral do eucalipto. In: BARROS, N.F. de; NOVAIS, R.F. (Ed). Relação solo-eucalipto, Viçosa: Editora Folha de Viçosa, 1990, cap.2, p.25-98. 
OLSON, J.S Energy storage and the balance of producers and decomposers in ecological systems. Ecology, v.44, n.2, p.322-331, 1963.

OSTERBAG, R.; HOBBIE S.E. Early stages of root and leaf decomposition in Hawaiian forests: effects of nutrient availability. Oecologia, v.121, p.564573, 1999.

PHILLIPS, R.P.; FISHER, J.T.; MEXAL, J.G. Fuelwood production utilizing Pinus eldarica and sewage sludge fertilizer. Forest Ecology and Management, v.16, p.95-102, 1986.

POGGIANI, F. Ciclagem de nutrientes em ecossistemas de plantações florestais de Eucalyptus e Pinus. Implicações silviculturais. Piracicaba, SP, 1985, 211p. Tese (Livre Docência) - Escola Superior de Agricultura "Luiz de Queiroz", Universidade de São Paulo.

POGGIANI, F.; SCHUMACHER, M. V. Atmospheric inputs compared with nutrient removed by harvesting from Eucalyptus plantation. Implications for sustainability. In: "IUFRO Conference on Silviculture and improvement fo Eucalypt". Proceedings. Salvador. Colombo: EMBRAPA. Centro nacional de Pesquisa de Florestas. 4v., p:68-74, 1997.

POGGIANI, F.; BENEDETTI, V. Aplicabilidade do lodo de esgoto urbano em plantações de eucalipto. Silvicultura, v.80, p.48-52, 1999.

POGGIANI, F.; GUEDES, M.C.; BENEDETTI, V. Aplicabilidade de biossólido em plantações florestais: I. reflexo no ciclo dos nutrientes. In: BETTIOL, W.; CAMARGO, O. A. (Ed). Impacto Ambiental do Uso Agrícola do Lodo de Esgoto. Jaguariúna: EMBRAPA Meio Ambiente, cap.8, p.163-178, 2000.

POLGLASE, P.J.; MYERS, B.J. Tree plantation for recycling effluent and biosolids in Australia. In: ELDRIDGE, K.G. (Ed). Environmental management: the role of eucalypts and other fast growing species. Proceedings of the Joint Australian/Japanese Workshop held in Australia, $\mathrm{p}$. 100-109, 1995.

PRESCOTT, C.E.; TAYLOR, B.R.; PARSONS, W.F.J.; PARKINSON, D. Nutrient release from decomposing litter $n$ Rocky Mountain coniferous forests: influence of nutrient availability. Canadian Journal of Forest Research, v.23, p.1576-1586, 1993a. 
PRESCOTT, C.E.; McDONALD, M.A.; GESSEL, S.P.; KIMMINS, J.P. Longterm effects of sewage sludge and inorganic fertilizers on nutrient turnover in litter in a coastal Douglas fir forest. Forest Ecology and Management, v.59, n.149-164, 1993b.

PRESTON, C.M.; TROFYMOW, J.A., SAYER, B.G.; NIU, J. ${ }^{13} \mathrm{C}$ nuclear magnetic resonance spectroscopy with cross-polarization and magic-angle spinning investigation of the proximate-analysis fractions used to assess litter quality in decomposition studies. Canadian Journal of Botany, v.75, p.1601-1613, 1997.

RAIJ, B. van; ANDRADE, J.C. de; CANTARELLA, H. e QUAGGIO, J.A. Análise química para avaliação da fertilidade de solos tropiciais (Ed). Campinas: Instituto Agronômico, 2001. 285p.

RANJER, J.; TURPAUT, M.P. Input-output nutrient budgets as a diagnostic tool for sustainable Forest management. Forest Ecology and Management, v.122, p.139-154, 1999.

RIEKERK, $\mathrm{H}$. Effects of sludge disposal on drainage solutions of two forest soils. Forest Science, v.27, n.4, p.792-800, 1981.

RYAN, M.G; MELLILO, J.M.; RICCA, A. A comparision of methods for determining proximate carbon fractions of forest litter. Canadian Journal Forest Research, v.20, p.166-171, 1990.

ROBINSON, M.B.; POGLASE, P.J.; WESTON, C.J. Loss of mass and nitrogen from biosolids applied to pine pantation. Australian Journal of Soil Science, v.40, p.1027-1039, 2002.

ROCHA, G.N. Monitoramento da fertilidade do solo, nutrição mineral e crescimento de um povoamento de Eucalyptus' grandis fertilizado com biossólido. Piracicaba, 2002. 48p. Dissertação (Mestrado) - Escola Superior de Agricultura "Luiz de Queiroz", Universidade de São Paulo.

ROS, C.O.; CERETTA, C.A.; FRIES, M.R. Lodo de esgoto: efeito imediato no milheto e residual na asssociação aveia-ervilhaca. Revista Brasileira de Ciência do Solo, v.17, n.2, p.257-261, 1993.

SABEY, B.R. The use of sewage sludge as a fertilizer. Enviromental Engineering Series, v.72, p.108-112, 1974. 
SANGER, L.J.; COX P.; SPLATT, P.; WHELAN, M.J.; ANDERSON, J.M. Variablity in the quality of Pinus sylvestris needles and litter from sites with different soil characteristics: lignin and phenylpropanoid signature. Soil Biology and Biochemistry, v.28, n.7, p.829-835, 1996.

SANTANA, R.C.; BARROS, N.F. de; NEVES, J.C.L. Biomassa e conteúdo de nutrientes de procedências de Eucalyptus grandis e Eucalyptus saligna em alguns sítios florestais do Estado de São Paulo. Scientia Forestalis, v.56, n.155-169, 1999.

SANTOS, H.S.; TSUTIYA, M.T. Aproveitamento e disposição final do lodo de estações de tratamento do Estado de São Paulo. Engenharia Sanitária e Ambiental, v.2, n.2, p.70-82, 1997.

SAROOSHI, R.A.; CRESSWEL, G.C.; TESORIERO, L.; MILHAM, P.J.; BARCHIA, I.; HARRIS, A.M. Effect of biosolids compost on two NSW coastal soils used to grow vegetables. Australian Journal of Soil Research, v.40, p.761-774, 2002.

SCHLESINGER, W.H. Biogeochemistry: na analysis of global change. San Diego: Academic Press, 1996. 359p.

SCHUMACHER, M.V. Aspectos da ciclagem de nutrientes e do microclima em talhões de Eucalyptus camaldulensis Dehnh, E. grandis Hill ex Maiden e E. torelliana F. Muell. Piracicaba, SP, 1992, 87p. Dissertação (Mestrado) Escola Superior de Agricultura "Luiz de Queiroz", Universidade de São Paulo.

SCHUMACHER, M.V.; POGGIANI, F. Produção de biomassa e remoção de nutrientes em povoamentos de Eucalyptus camaldulensis Dehnh, Eucalyptus grandis Hill ex Maiden e Eucalyptus toleriana F. Muell, plantados em Anhembi-SP. Ciências Florestais, v.3, n.1, p.21-34, 1993.

SGARBY, F. Produtividade de Eucalyptus sp. Em função do estado nutricional e da fertilidade do solo em diferentes regiões do estado de São Paulo. Piracicaba, 2002. 101p. Dissertação (Mestrado) - Escola Superior de Agricultura "Luiz de Queiroz", Universidade de São Paulo.

SILVA, H. D. Modelos matemáticos para a estimativa da biomassa e do conteúdo de nutrientes em plantações de Eucalyptus grandis de diferentes idades. Curitiba, 1996. 101p. Tese (Doutorado) - Universidade Federal do Paraná 
SILVEIRA, R.L.V.A.; HIGASHI, E.N.; GONÇALVES, A.N.; MOREIRA, A. Avaliação do estado nutricional do Eucalyptus: diagnose visual, foliar e suas interpretações. In: GONÇALVES, J.L.M.; BENEDETTI, V. (Ed). Nutrição e fertilização florestal. Piracicaba: IPEF, 2000, cap.3, p.79-104.

SIMONETE, M.A.; KIEHL, J.C.; ANDRADE, C.A.; TEIXEIRA, C.F.A. Efeito do lodo de esgoto em um Argissolo e no crescimento e nutrição de milho. Pesquisa Agropecuária Brasileira, v.38, n.10, p.1187-1195, 2003.

SLOAN, J.J.; BASTA, N.T. Remediation of acid soils by using alkaline biosolids. Journal of Environmental Quality, v.24, n.6, p.1097-1103, 1995.

SMITH, C.T.; CARNUS, J.M. Biosolids - planning and design. In: The forest alternative. Principles and practice of residuals use. INTERNATIONAL SYMPOSIUM ON THE USE OF RESIDUALS AS SOIL AMENDMENTS IN FOREST ECOSYSTEMS. Proceedings/l Seattle: University of Washington, 1997. p.45-52.

STEVENSON, F.J. Humus chemistry: genesis, composition, reactions. 2.ed. New York: John Wiley, 1994. 496p.

STREET, H. E.; ÖPIK, H. Fisiologia de Angiospermas: crescimento e desenvolvimento. São Paulo, EDUSP, 1974. 332p.

TARGINO, M.G.; CORREIA, R.T.P.; CARVALHO, C.P. Quando o Amor à Ciência ainda basta. In: DUARTE, J.; BARROS, A.T. (Ed). Comunicação para ciência, ciência para comunicação. Brasília: EMBRAPA Informação Tecnológica, cap.1, 2003. 338p.

TYLER, L.D.; McBRIDE, M.B. Mobility and extractability of cadmium, copper, nickel and Zinc in organic mineral soils columns. Soil Science, v.134, p.198205, 1989.

TSADILAS, C.D.; MATSI, T.; BARBAYANNIS, N.; DIOMOYANNIS, D. Influence of sewage sludge application on soilproperties and on tha distribution and availability of heavy metal fractions. Communication Soil Science and Plant Analisys, v.26, n.15/16, p.2603-2619, 1995.

TSUTYA, M.T. Alternativas de disposição final de biossólidos gerados em estações de tratamento de esgoto. In: BETTIOL, W. e CAMARGO, O. A. $(E d)$. Impacto ambiental do uso agrícola do lodo de esgoto. Jaguariúna: EMBRAPA Meio Ambiente, 2000. cap.4, p.69-106. 
TSUTYA, M.T. Alternativas de disposição final de biossólidos. In: TSUTYA, M.T.; COMPARINI, J.B.; ALEM SOBRINHO, P.; HESPANHOL, I.; CARVALHO, P.C.T.; MELF, A.J.; MELO, W.J.; MARQUE, M.O. (Ed). Biossólidos na AGRICULTURA. São Paulo: SABESP, 2001. cap.5, p.133180.

TAPPI (Technical Association of Pulp and Paper Industry). TAPPI test methods. T222 om-98 e T207 om-93. Atlanta: TAPPI press, 1999.

U.S.E.P.A. Biosolids generation, use, and disposal in the United States. Solid Waste and Emergency Response (5306W), Office of Solid Waste, Washington. EPA 530-R-99-009, setembro de 1999. 74p.

VAZ, L.S.V. Crescimento inicial, fertilidade do solo e nutrição de um povoamento de Eucalyptus grandis fertilizado com biossólido. Piracicaba, SP, 2000. 41p. Dissertação (Mestrado) - Escola Superior de Agricultura "Luiz de Queiroz", Universidade de São Paulo.

VAZ, L.M.S; GONÇALVES, J.L.M. Uso de biossólidos em povoamento de eucalipto: efeito em atributos químicos do solo, no crescimento e na absorção de nutrientes. Revista Brasileira de Ciência do Solo, v.26, n.3, p.747-758, 2002.

VELASCO-MOLINA, M. Nitrogênio e metais pesados em latossolo e eucalipto cinqüenta e cinco meses após aplicação de biossólido. Piracicaba, SP. 2004, 62p. Dissertação (Mestrado) - Escola Superior de Agricultura "Luiz de Queiroz", Universidade de São Paulo.

VITAL, A. R. T. Efeito do corte raso no balanço hídrico e na ciclagem de nutrientes em uma microbacia reflorestada com eucalipto. Piracicaba, 1996. 105p. Dissertação (Mestrado) - Escola Superior de Agricultura "Luiz de Queiroz", Universidade de São Paulo.

VITAL, A.R.T.; LIMA, W.P.; POGGIANI, F.; CAMARGO, F.R.A de. Bioquímica de uma microbacia após o corte raso de uma plantação de eucalipto de 7 anos de idade. Scientia Forestalis, v.55, p.17-28, 1999.

ZHANG, H.; BASTA, N.; STIEGLER, J. Using biosolids as a plant nutrient source. 2001: 1-4, http://pearl.agcomm.okstate.edu/plantsoil/soils/cr-220.pdf (03 jan. 2004). 
WEETMAN, G.F.; McDONALD, M.A.; PRESCOTT, C.E.; KIMMINS, J.P. Responses of Western hernlock, Pacific silver fir and Western red cedas plantations ou northen Vancouver Island to applications of sewage sludge and inorganic fertilizer. Canadian Journal of Forestry Researsh, v.23, n.9, p.1815-1820, 1993. 